\title{
A Political Economy Analysis of Agricultural Development of Turkey's South-eastern Anatolia Region
}

\author{
Inci, Ulas
}

How to cite:

Inci, Ulas (2019) A Political Economy Analysis of Agricultural Development of Turkey's South-eastern Anatolia Region. Doctoral thesis, Swansea University. http://cronfa.swan.ac.uk/Record/cronfa51067

Use policy:

This item is brought to you by Swansea University. Any person downloading material is agreeing to abide by the terms of the repository licence: copies of full text items may be used or reproduced in any format or medium, without prior permission for personal research or study, educational or non-commercial purposes only. The copyright for any work remains with the original author unless otherwise specified. The full-text must not be sold in any format or medium without the formal permission of the copyright holder. Permission for multiple reproductions should be obtained from the original author.

Authors are personally responsible for adhering to copyright and publisher restrictions when uploading content to the repository.

Please link to the metadata record in the Swansea University repository, Cronfa (link given in the citation reference above.)

http://www.swansea.ac.uk/library/researchsupport/ris-support/ 


\section{SWANSEA UNIVERSITY \\ COLLEGE OF ARTS AND HUMANITIES \\ DEPARTMENT OF POLITICAL AND CULTURAL STUDIES}

A Political Economy Analysis of Agricultural Development of

Turkey's South-eastern Anatolia Region

\section{ULAS INCI}

MARCH 2019

Submitted to Swansea University in fulfilment of the requirements for the Degree of Doctor of Philosophy 


\begin{abstract}
Rational choice theory, which has a prominent position in the study of politics, generally focusses on developed Western countries, former African colonies and Latin American countries but neglects countries with an imperial background. This research aims to fill this gap paying attention to Turkey's political economy and more specifically to the Kurdish Question and agricultural development of the South-eastern Anatolia Region. Rational choice theory pays attention to intra-elite relationships in state formation but tends to overlook the role of the peripheral movements in shaping intra-elite relationships. Following the founding of modern Turkey, over time, a series of peripheral movements emerged. The highly centralised formation of the Turkish state, the conflicting relationship between the centre and the periphery, and its effects on intra-elite relationships in the dominant coalition will be discussed in this research, particularly within the context of the Kurdish Question. The Question is relevant to the relatively less development of the South-eastern Anatolia Region. The development narrative is used to both gain insights in the development problems of the region and in the Question. Since 2001, both neoliberal policies at national level and development interventions at regional level were concurrently employed to deal with the region's problems. The effects of these policies will be under investigation to then critically assess the use of the rational choice theory for countries with an imperial history.
\end{abstract}




\section{DECLARATION AND STATEMENT}

This work has not previously been accepted in substance for any degree and is not being concurrently submitted in candidature for any degree.

Signed (candidate)

Date

\section{STATEMENT 1}

This thesis is the result of my own investigations, except where otherwise stated. Where correction services have been used, the extent and nature of the correction is clearly marked in a footnote(s).

Other sources are acknowledged by footnotes giving explicit references. A bibliography is appended.

Signed (candidate)

Date

\section{STATEMENT 2}

I hereby give consent for my thesis, if accepted, to be available for photocopying and for interlibrary loan, and for the title and summary to be made available to outside organisations.

Signed (candidate)

Date 


\section{TABLE OF CONTENTS}

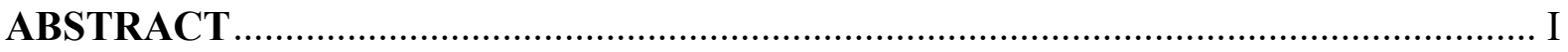

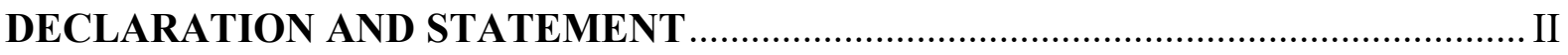

TABLE OF CONTENTS ...................................................................................... III

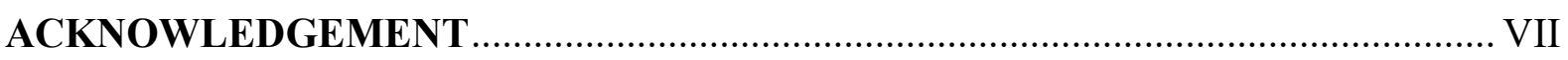

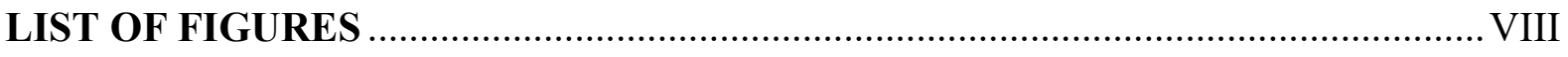

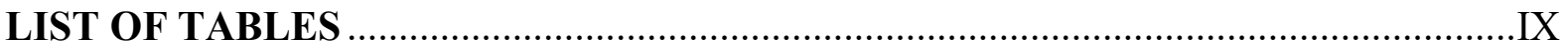

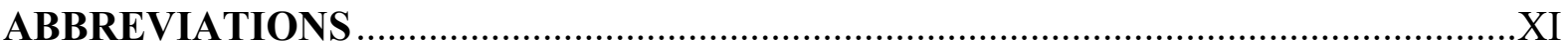

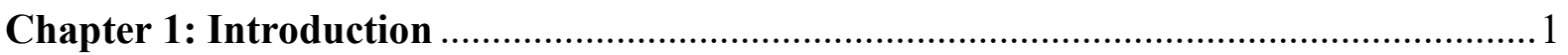

1.1 The Context and the Contribution of the Study ................................................. 1

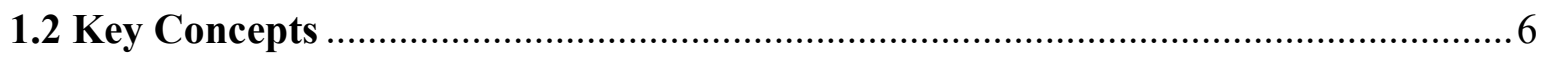

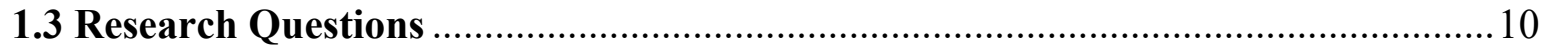

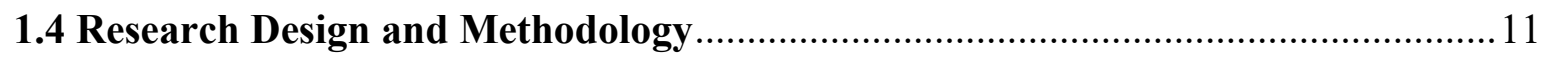

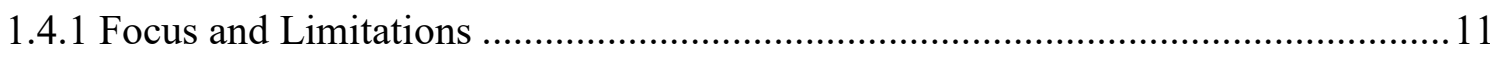

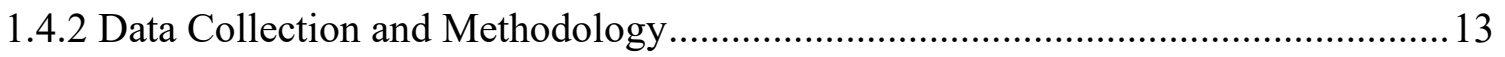

1.4.3 Sampling for the Data Collection and Conduct of the Fieldwork ........................... 15

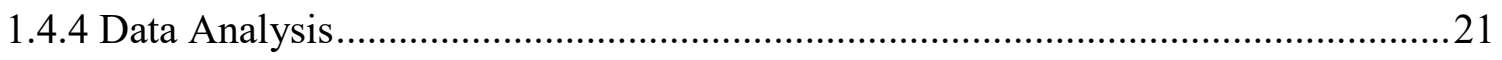

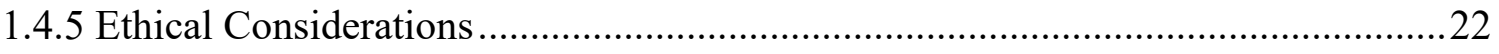

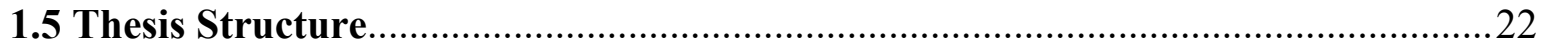

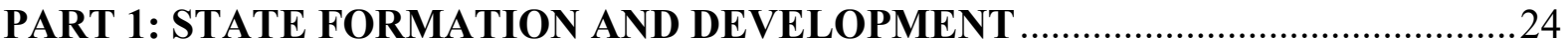

Chapter 2: State Formation and Development from the Aspect of the Conflicting Relationship between the Centre and the Periphery ..................................................24

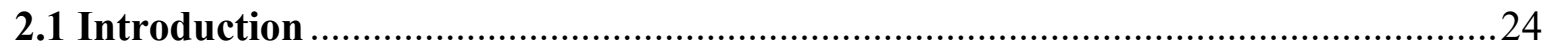

2.2 State Formation and Development in Rational Choice Theory and Its Critical

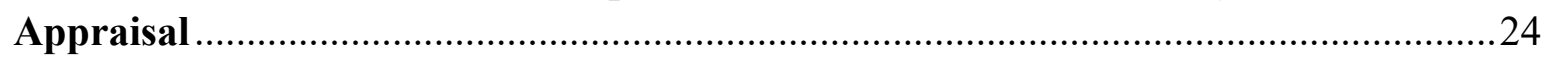

2.2.1 The Cases of England and France as Developed Countries ..................................28

2.2.2 The Case of Less Developed Countries in Africa as Former Colonies .................... 33

2.3 The Case of Turkey: State Formation and Development from the Aspect of the Conflicting Relationship between the Centre and the Periphery ................................ 34

2.3.1 Turkey's Path Dependency: The Political Economic Heritage from the Ottomans 36

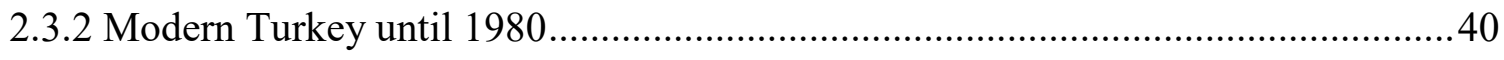

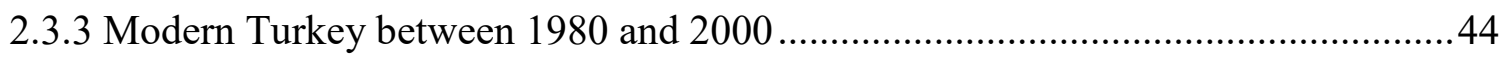

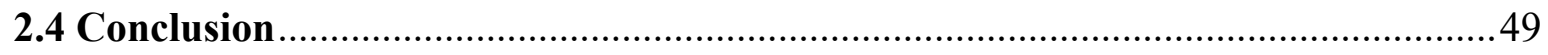


Chapter 3: The Kurdish Question as a Peripheral Movement: Political Collective Action

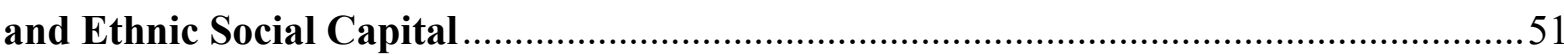

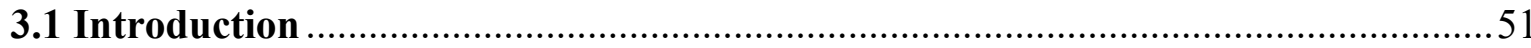

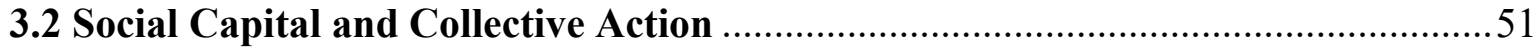

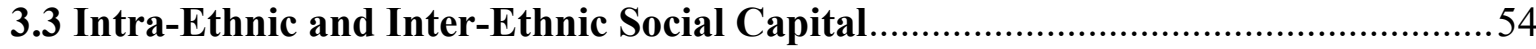

3.4 The Ethnic Social Capital of Kurds in Turkey ...........................................................56

3.5 The Formation of Kurdish Ethnic Social Capital in the Kurdish Question ...........58

3.6 The Military Narrative and the Development Narrative around the Kurdish

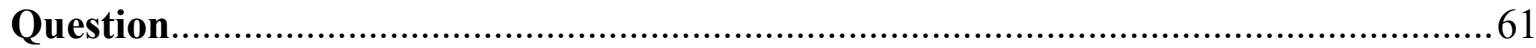

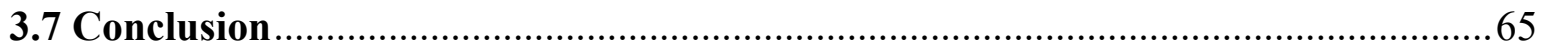

Chapter 4: Turkey's Political Economy and the South-eastern Anatolia Region's Agriculture

4.1 Introduction 67

4.2 Turkey's Political Economy and the Neoliberal Agricultural Transformation between 1980 and 1989

4.3 Turkey's Political Economy and the Neoliberal Agricultural Transformation

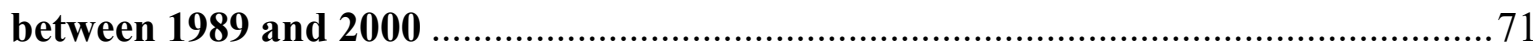

4.4 The Agricultural Reform Implementation Project …............................................. 75

4.5 The South-eastern Anatolia Development Project and Agriculture .......................85

4.5.1 The South-eastern Anatolia Development Project .................................................. 85

4.5.2 The South-eastern Anatolia Region and Agriculture …........................................90

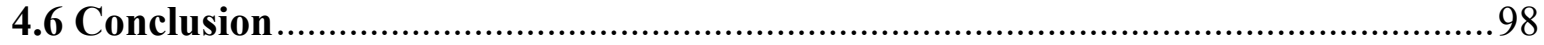

Chapter 5: Turkey's Political Economy and the Kurdish Question Since 2001 ........... 100

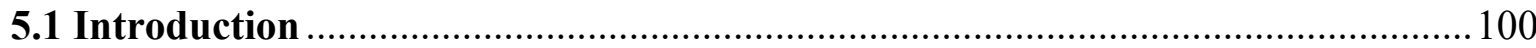

5.2 The Conflicting Relationship between the JDP Government and the State

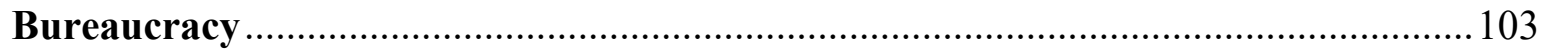

5.2.1 The State Bureaucracy Attacks on the JDP Government .................................... 104

5.2.2 The JDP Government Gains the Upper Hand ...................................................... 106

5.3 The Kurdish Question in the Era of the JDP Government and the Development Narrative 111

5.3.1 The Kurdish Question between 2001 and 2008................................................... 112

5.3.2 The Kurdish Question between 2009 and 2013 ................................................. 116

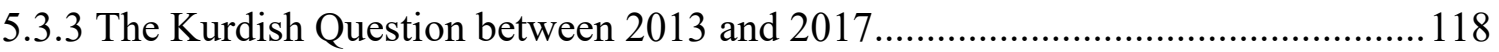

5.4 The Combination of Neoliberal Policies with the GAP-based Development Policies 120 
PART 2: NEOLIBERAL AGRICULTURAL POLICIES AND AGRICULTURAL DEVELOPMENT

Chapter 6: The Neoliberal Agricultural Transformation of Less Developed Countries 124

6.1 Introduction 124

6.2 Neoliberalism and Neoliberal Economic Policies 124

6.3 Rational Choice Theory and Its Links with Neoliberalism 129

6.4 Rational Choice Theory and Neoliberal Policies in Agriculture 131

6.5 The Critical Appraisal of Rational Choice Theory and Neoliberal Agricultural Policies 135

6.6 Conclusion 141

Chapter 7: A Political Economy Analysis of Agricultural Development of the Southeastern Anatolia Region 142

7.1 Introduction 142

7.2 The Effects of the Neoliberal Transformation on Agricultural Production in the South-eastern Anatolia Region 143

7.2.1 The Main Production Strategies of Agricultural Producers and Changes in the Use of Agricultural Lands Associated with Crop Types ...................................................... 146

7.2.2 Agricultural Production Costs, Input Subsidies, and the Input Market.................. 149

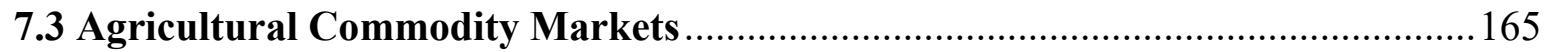

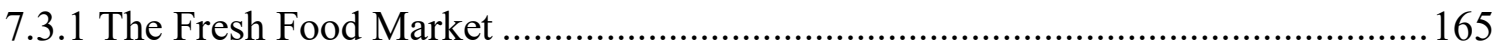

7.3.2 The Processed Agricultural Commodity Market................................................. 172

7.4 The Privatisation of the TEKEL Company and the Tobacco Market .................. 189

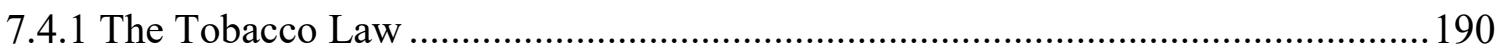

7.4.2 Contract Farming in Tobacco and Illicit Tobacco Sales ...................................... 191

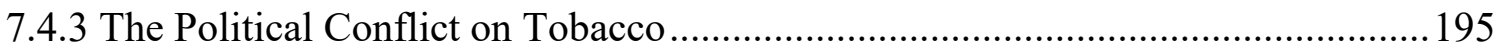

7.5 Successful and Unsuccessful Cases of Government Interventions ........................ 198

7.5.1 Designing Government Interventions through the Poly-Centric Governance....... 199

7.5.2 Unsuccessful Cases in the SAR of Government Interventions ............................201

7.5.3 Successful Cases of Government Interventions in the SAR .................................206

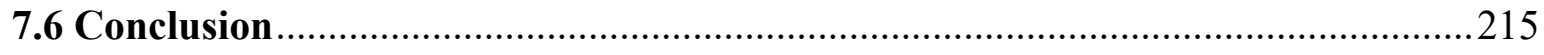

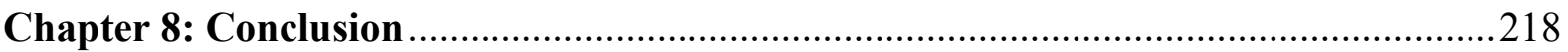

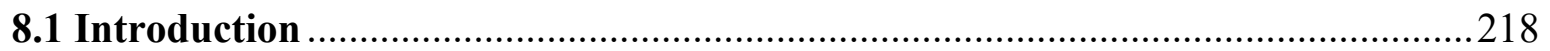

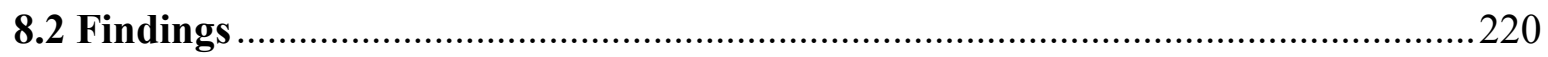




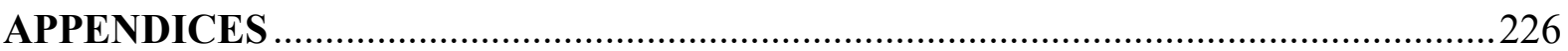

Appendix 1: Qualitative Interview and Focus Group Questions ....................................226

Appendix 2: The Cities and the Towns Visited in the Fieldwork ...................................2230

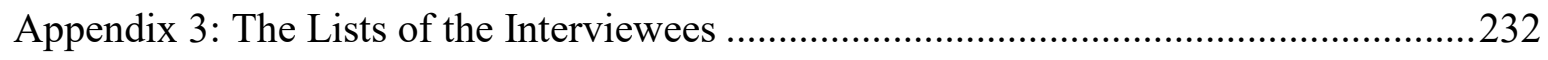

Appendix 4: The Farmers Interviewed, Their Agricultural Enterprise Sizes and Land

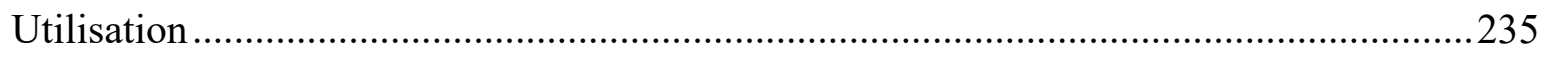

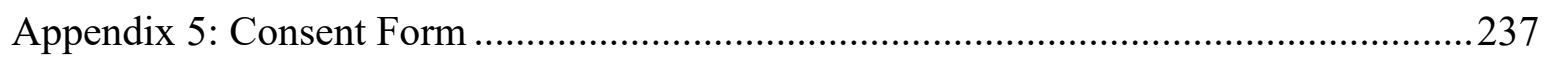

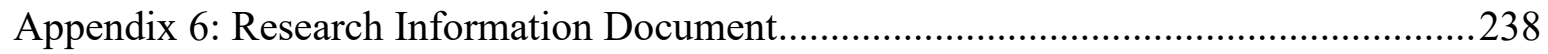

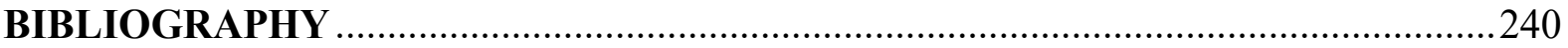




\section{ACKNOWLEDGEMENT}

First and foremost I would like to thank my supervisor Dr Krijn Peters. He always showed me the correct path to get my doctoral degree with all his contributions of time, ideas and feedbacks making my doctoral thesis productive and inspiring. Given that I have experienced very tough times since the mid-2016, I will always remain thankful to him for his support going beyond supervision. Many thanks also to the members of the viva panel: Dr Joost Jongerden, Dr Gerrard Clarke and Dr Matthew Wall, for their valuable comments and encouragement. I would like to express my thanks to Liz Whitwell and Gabriela Wasiniak who always offered me their substantial administrative advice and assistance.

Deepest gratitude goes to all the people who gave their valuable time to answer my questions during my fieldwork, and my friends who helped me to visit different locations and contact the interviewees. Data collection would not have been possible without their support.

I would like to extend my sincere thanks to my friends providing me intellectual and emotional support, specifically to Utku Umut Yuce, who also provided me with his financial help to successfully finish the programme. I am greatly indebted to my uncles, Ahmet Bicinciler and Aziz Bicinciler for their financial help and continual encouragement.

Finally, I am deeply grateful to my family. My father always used to motivate me to pursue my passion for education. May his soul rest in peace. My mother, sister, brother, sister-inlaw, nephew and niece always put their trust in me and gave their great support. I am very lucky to have such a great family. 


\section{LIST OF FIGURES}

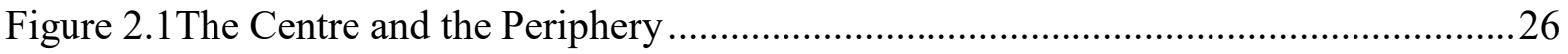

Figure 4.1 Different Political-Economic Regimes Applied to the Agricultural Sector ........... 76

Figure 4.2 Agricultural Support in relation to Turkey's GDP ................................................ 80

Figure 4.3 Shares of Different Support Types in Total Agricultural Production ................... 81

Figure 4.4 The Nomenclature of Territorial Units for Statistics- Statistical Regions of Turkey

Figure 4.5 The South-eastern Anatolia Region and Its Cities ............................................ 86

Figure 4.6 The Use of Lands in the South-eastern Anatolia Region in the mid-1980's..........92

Figure 4.7 The Areas Intended to Be Irrigated within the Scope of the GAP in 2015 ...........94

Figure 4.8 The Main Geographical Features of the SAR .....................................................95

Figure 5.1 The Percentage Values of Public Investment in the GAP .................................. 103

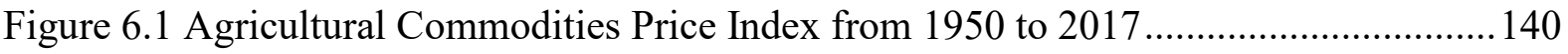

Figure 7.1 Most of the Area in the SAR where Bore Wells Are Excessively Being Used ... 162

Figure 7.2 The Main Supply Line of Fresh Fruits and Vegetables..................................... 166

Figure 7.3 The Main Supply Line of Agricultural Raw Materials and Processed Food in the SAR 


\section{LIST OF TABLES}

Table 1.1The Brief Timeline of the Fieldwork ....................................................................... 16

Table 1.2 The Reference Sizes of Different Types of Agricultural Enterprises.

Table 4.1 The Main Points and the Details of the Agricultural Transformation Carried out in the $1980 \mathrm{~s}$

Table 4.2 Prominent Political Parties in Turkey between 1987 and 2001 ............................... 72

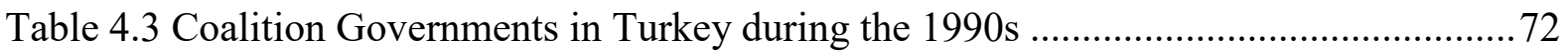

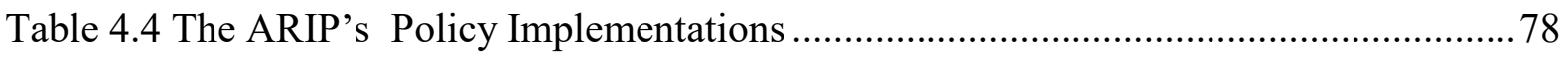

Table 4.5 Turkey's Agricultural GDP Growth Rates in US Dollar..................................... 82

Table 4.6 Turkey's Agricultural Support Growth and Agricultural GDP Growth.................82

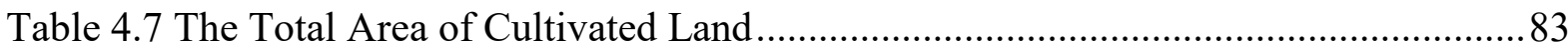

Table 4.8 The Percentage Distribution of Number and Land Share of AEs by Size............... 84

Table 4.9 The Comparison between the SAR and Turkey in Terms of Per Capita Income.... 90

Table 4.10 The Sectorial Shares of Each City in the SAR in 2017 .......................................90

Table 4.11 The Distribution of Agricultural Lands Among the SAR's Cities .......................91

Table 4.12 Urbanisation and Ruralisation Rates of SAR's Cities in 2012 ............................92

Table 4.13 Changes in the Total Cultivated Lands in the SAR between 1989 and 1999 ........93

Table 4.14 The Most Cultivated Crop Types in the SAR's Cities in 2017 .............................96

Table 4.15 The Shares of Areas Allocated for Field Crops, Vegetables and Fruits ................97

Table 4.16 The Percentage Distribution of Number and Land Share of AEs in the SAR and

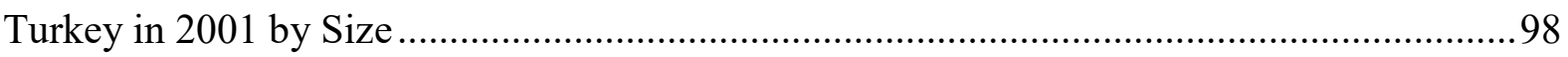

Table 6.1 Main Policies and Aims of a Typical Structural Adjustment Programme ............ 127 Table 6.2 Average Growth Rates of Gross Domestic Product and Per Capita Income of

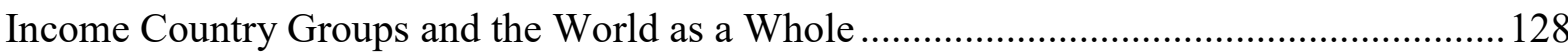

Table 6.3 Growth Rates of Agricultural Value Added in East Asian Countries between 1981 and 2016

Table 6.4 The Comparison between Various Regions as to Agricultural Growth Rates in the Period between 1981 and 2016 138

Table 7.1 Annual Average Growth Rates of Turkey and its Regions at 2011 Prices 144

Table 7.2 Changes in the Use of Agricultural Lands in Turkey and the SAR between 2000 and 2016 
Table 7.3 Crop Groups and Changes in the Cultivated Areas in the SAR and Turkey between 2000 and 2016

Table 7.4 Cultivated Lands and Production Levels of the Most Produced Crops in Each Crop Groups in the SAR between 2004 and 2016

Table 7.5 Productivity Differences between Rain-fed and Irrigated Agricultural Methods in the Case of Sanliurfa

Table 7.6 The Average Growth Rates of Different Types of Irrigation Equipment in the SAR

Table 7.7 The Cooperative Unions in the SAR, Their Current Status and Their Areas of Operation

Table 7.8 Crop Types in Which Each Producers Union Carries Out Agricultural Marketing Operations

Table 7.9 The Prices of Fresh Agricultural Commodities at Different Nodes of the Agricultural Marketing Network in 2018

Table 7.10 Percentage Changes in Agricultural Machineries Before and After the Introduction of the Rural Development Support Programme 


\section{ABBREVIATIONS}

ACC : Agricultural Credit Cooperatives

AE : Agricultural Enterprise

ARIP : Agricultural Reform Implementation Project

ASC : Agricultural Sale Cooperative

ASCU : Agricultural Sale Cooperative Union

BDP : Peace and Democracy Party

CHP : Republican People's Party

da $:$ decare

DF : Diesel and Fertilizer

DIS : Direct Income Support

DP : Democrat Party

DSI : State Hydraulic Works

DTP : Democratic Society Party

EU : European Union

EU-CAP : European Union Common Agricultural Policy

FAO : Food Agriculture Organisation

GAP : South-eastern Anatolia Project

GAP-RDA : GAP-Regional Development Agency

GAP-TEYAP : GAP-Agricultural Education and Extension Project

GATT : General Agreement on Tariffs and Trade

GDP : Gross Domestic Product

ha : hectare

ICSSS : Improved, Certified Seed, Seedling and Sapling

IMF : International Monetary Fund

JDP : Justice and Development Party

KCK : Union of Communes in Kurdistan

LAE : Large-scale Agricultural Enterprise

MAE : Medium-scale Agricultural Enterprise

MOAF : Ministry of Agriculture and Forest

NMP : Nationalist Movement Party

OECD : Organisation for Economic Co-operation and Development

PKK : Kurdistan Worker's Party

RCT : Rational Choice Theory 


$\begin{array}{ll}\text { RDSP } & \text { : Rural Development Support Programme } \\ \text { SA } & \text { : Soil Analysis } \\ \text { SAE } & \text { : Small-scale Agricultural Enterprise } \\ \text { SAR } & \text { : South-eastern Anatolia Region } \\ \text { TAPDK } & : \text { Tobacco and Alcohol Market Regulatory Authority } \\ \text { TGNA } & : \text { Turkish Grand National Assembly } \\ \text { TIGEM } & : \text { General Directorate of Agricultural Enterprises } \\ \text { TL } & : \text { Turkish Lira } \\ \text { UNDP } & : \text { United Nations Development Programme } \\ \text { US } & : \text { United States } \\ \text { WB } & : \text { World Bank } \\ \text { WP } & : \text { Welfare Party }\end{array}$




\section{Chapter 1: Introduction}

\subsection{The Context and the Contribution of the Study}

When the Ottoman Empire collapsed, it left neither secure nor prosperous people in a disintegrated and war-affected Anatolia and Thrace. Mustafa Kemal Ataturk, a representative of the military class, became involved in shaping the country's path under challenging circumstances. He managed to gather a group of people from within the army and set out to save the last pieces of territory of the Empire. When he founded modern Turkey in 1923, he had to deal with a returning question: how will the country achieve both security and prosperity? The discussion on modernisation among Ottoman elites dated back to the earlyperiod of the $18^{\text {th }}$ century, and focussed on how the Ottoman army could catch up with the strong armies in Europe (Aytekin, 2013). The widening developmental disparity between the Ottomans and its European counterparts intensified this discussion. After the Ottoman modernisation was extended to reform the state and the society in the following centuries, Ataturk found himself among reformist army officials. Therefore, when he came to power, he did not hesitate to shape Turkey as a modern, secular, republican and nationalist country.

This formation of the state incited reactions from two main groups, something which is present till this day: the conservatives and the Kurds. Their reactions were dominated by two topics: state formation and development. The conservatives opposed the removal of the caliphate, the introduction of secularism, the disengagement of modern Turkey from the country's past and traditional values for westernisation (Yavuz, 2003, pp. 46-48), and the creation of a secular, westernised bourgeoisie at the expense of the peasantry with conservative values. In addition, the Kurds opposed the recognition of Turkishness as the only national identity and the removal of their autonomous rights with republicanism referring to high centralisation (Yavuz, 2001).

When Turkey transitioned to a multi-party system at the end of World War II, the state relaxed its political grip over civil political involvement. In the late 1960s, Kurds were ideologically divided into two main categories: Islamist Kurds, and secular Kurds including Marxists and nationalists. Islamist Kurds have owned similar complaints as the conservatives towards state formation and development whereas secular Kurds have focussed on issues such as democratic rights, decentralisation, national identity and developmental problems of eastern Turkey (Yavuz, 2001). Overall, the discussions about state formation and development have never lost its relevance since Turkey was founded. 
After safeguarding itself by suppressing the above mentioned responses in the $1920 \mathrm{~s}-30 \mathrm{~s}$, the modern state showed determination in achieving development. During the early-period of the Republic, it first attempted to leave development to market actors, refraining from state interventions, using a classical liberal recipe. But this failed, as its economy had no mature capitalist class. Lacking such a class that could carry out developmental efforts on their own, the state attempted to create such a class dependent, applying economic protection and government interventions for a sustained period. Intentional development arrangements and efforts have, nationally or regionally, been part of economic policy design and implementations since then.

The first massive flow of the masses from rural to urban areas in developing western Turkey took place in the 1950s. Urbanisation has constantly risen after that time, compounding the existing political and socio-economic problems. Democratic and economic demands have remained on the agenda of ordinary people, though security problems and military coups occasionally have blocked these.

Turkey's socio-economic transformation has created strong peripheral movements among the before mentioned groups, which dramatically intensified in the 1960 and 70s. While capitalist development was progressing, different classes and factions of classes continued to emerge, making the political setting more complicated along cultural and economic dimensions. Political conflicts started to depend on urban-based groups characterised by emerging developmental and cultural problems. While most secular Turks from different classes were championing the existing Kemalist modern transformation, two distinct groups were opposing them, criticising the state formation and the development pathway. One of those groups included leftist Turkish and Kurdish youth, part of the working class and secular Alevis and Kurds; the other involved conservative Turkish and Kurdish workers, and conservative small and medium-scale capital owners, some of which later became large-scale capitalists.

All these groups have become highly politicised, competing with each other and putting pressure on the state to gain what they want. While the developmental disparity between western Turkey and other regions has widened and created complaints and demands, military coups have mounted to shape the political terrain. All of these disagreements and competition resulted in the rise of the Kurdish political movement and the Islamic movement in the 1990s, despite all the military interventions, and peaked after 2002 when the conservative Islamist Justice and Development Party (JDP) came to power. 
Because of the memories of the historical rivalry between the Ottomans and European big powers, and of modern Turkey's choice to adopt westernisation as a way of modern development, the ordinary Turkish citizen occasionally makes the comparison between Turkey and developed Western countries to understand to what extent and why Turkey has succeeded or failed. Focusing on this question, this thesis discusses how developed countries achieved development in their history (see chapter 2). In doing so, it uses rational choice theory (RCT) in a critical manner. RCT is a dominant theoretical approach in politics for many years now. Prosperity and Violence and Development Dilemma written by Bates (2017), and Violence and Social Orders written by North, Wallis, and Weingast (2009) are seminal works in RCT and our main focus here. While critically assessing these studies, the research underlines that they comprehend state formation and development as a result of interaction and rivalries within a dominant coalition. They do not however examine how any reaction that comes from outside the dominant coalition influences the political-economic development and shapes the dominant coalition itself. The research also argues that regional diversities do not cause regionalism, shaping a political terrain hampering development. If a highly centralised state blocks political access and participation through suppressing the people, this may led those people to revert to regionalism.

RCT scholars generally take the cases of African former colonies and occasionally Latin American countries to make comparisons with developed countries in order to grasp the dynamics that are responsible for developmental failures in developing countries. The gap in $\mathrm{RCT}$ is that it does not recognise the unique circumstances of developing countries with an imperial background (e.g. Turkey, China, Thailand and Iran etc.). These constitute a different type of category for examining how state formation and development take place. This research therefore focusses on Turkey's state formation and development starting from the political, economic and institutional heritage of the Ottoman Empire to present day, in order to critically appraise RCT.

Since its foundation, the character of the Turkish state, and its formation and transformation have become focus of interest among scholars. In general, the alliance between the military and capitalist classes is accepted as shaping and keeping power along the trajectory of capitalist development. However, some argue that the military is the main actor determining Turkey’s political trajectory (see Başkaya, 1991; Cizre-Sakallioglu, 1997; Feroz, 1993/1995; Kucukaydin, 2013b; Mardin, 1973), indicating that the military bureaucracy itself has classlike interests to maximize politically. Others maintain that political-economic needs of the 
bourgeoisie dominate politics by interacting with international/global capitalism, and that the military forcibly shapes the political terrain when it is required by the bourgeoisie (see Boratav, 2005; Yasli, 2014). In this sense, Turkey's swing from semi-democratic to antidemocratic orders or vice versa results from the problems of capital accumulation of the bourgeoisie in the context of centre-periphery relationships in the international system.

This research accepts the significant role of the bourgeoisie in the dominant coalition but argues that the military has a key role in it. This role is a historical institutional fact spanning from the Ottomans to modern Turkey.

Turkey's political economic problems manifest themselves most clearly in the Kurdish Question and agricultural development of the South-eastern Anatolia Region (SAR). As a peripheral movement, the Kurdish Question fits in an ethno-political problem, covering several sub-problems with regard to national identity, democratic rights and development. As long as these problems cannot be solved successfully, the modern Kurdish political movement remains one of the greatest domestic challenges to the Turkish state. The effect of the armed conflict between the Kurdistan Worker's Party (Partiya Karkerên Kurdistanê in Kurdish, PKK henceforth) and Turkey was one of the factors crippling Turkey's development in the 1990s.

The research critically approaches Olson's argument in Logic of Collective Action that political collective action in large groups can be explained by psychological factors (see Chapter 3). Relying on the studies of Ahn and Ostrom (2008), E. Ostrom and Ahn (2009) and Miedema (2010), this research argues that social capital plays a key role in political collective action, and that despite all the measures taken by the state, the never-ending strength of the Kurdish political movement stems from the strong intra-ethnic and inter-ethnic social capital formed by Kurds. The measures proposed by the state to solve the Question are devised in two narratives: the military narrative and the development narrative. The former aims to eliminate the PKK, whereas the latter to transform Kurds via the South-eastern Anatolia Project (GAP in Turkish, Guneydogu Anadolu Projesi): an integrated, multi-sectorial socioeconomic development project. But the social capital of Kurds has frustrated the disguised aims of the state so far.

When the JDP government came to power nearly two years after the deeply shocking 2001 economic crisis, the centre-periphery relations became tense because of national-level disputes exacerbated by changes in international political settings. Searching for support from 
the West, the government also directed its attention to the Kurdish Question to get support of Kurds. Meanwhile, the PKK, overcoming the arrest of its leader in 1999, revitalised itself in North Iraq where the Iraqi state lost its authority after the United States' (US) invasion.

In this political terrain, the ruling government took action to prevent the military bureaucracy from engaging in the Question via military measures, which may otherwise have caused their removal from power, similar to what happened to the Islamist Welfare Party (WP) in the 1990s. While they fostered the relationship with the US in relation to this country's interests in the Middle East and with the European Union (EU) to start Turkey's accession negotiations, they promoted democratic openings and commenced peace talks with the political elites of the Kurdish pro-party and even with the arrested leader of the PKK. Furthermore, they have remained loyal to pre-determined commitments to neoliberal policies that were given by the previous government to the bourgeoisie and international economic organisations. Finally, the JDP attempted to contribute to the development of the SAR through government interventions. The last two policies mentioned above may look contradictorily, but the political conditions the government has faced and the course of the Kurdish Question were determinant in pursuing them. The commitments to neoliberalism have provided the government with the support of international organisations and the bourgeoisie. Public investments in the region's agricultural development, without departing from market-based approaches, were aimed at getting the support of ordinary Kurds and enchanting the Kurdish bourgeoisie for a resolution to the Question.

The research aims to understand the political economic factors behind and the effects on the regional agricultural development of the simultaneous implementation of neoliberal agricultural policies at the national-level and government interventions at the regional-level since 2001. In doing so, it shows that the conflicting relations between the centre and the periphery have shaped the dominant coalition in Turkey, so contributing to what Violence and Social Orders discusses (see chapter 5).

By providing empirical findings, it, furthermore, critically assesses the arguments made by Robert Bates in Markets and States in Tropical Africa, which defies government interventions in agriculture and suggests that agricultural development must be left to freemarket dynamics. Our research finds that free market dynamics secured with neoliberal agricultural policies have created unfavourable results for especially smallholders since 2001 but favourable ones for merchants, brokers, exporters, supermarkets and agro-processors. It 
also shows that if government interventions are designed in accordance with the poly-centric governance approach, positive results can be obtained.

\subsection{Key Concepts}

As our main objective is to contribute to RCT from the point of state formation and development, we will introduce the key concepts of RCT and development.

\section{Rational Choice Theory}

RCT owns a dominant position in the social sciences as a theory which has nearly no area of politics untouched. True, rational choice scholars have enriched our understanding and knowledge of specific social phenomena in almost every subfield of social sciences; yet, all the theoretical arguments and inferences developed in those subfields have remained fragmented in a manner that has prevented the construction of a singular theory covering all the subfields (Wittek, Snijders, \& Nee, 2014, p. 2).

Displaying and critically assessing the methodological aspects of and variations in RCT require an effort beyond the aim of this section (see D. P. Green and Shapiro (1994); Boudon (2009); Wittek et al. (2014)). However, explaining its main assumptions may help to appreciate the nature of RCT.

Methodological individualism plays an essential role in constructing the methodological foundations of RCT. As Boudon (2009, p. 180) states, 'any social phenomenon is the effect of individual decisions, actions, attitudes and so forth', where individuals are 'concerned mainly with the consequences for themselves of their action. From this point, individual actions are supposed to be based on 'understandable motivations and/or reasons' (p. 180), referring to acting rationally. Rationality characterises the reason of individuals calculating costs and benefits of each in the set of possible actions, formulated as expected utility maximisation. For utility maximisation 'when confronted with an array of options, she picks the one she believes best serves her objectives' (D. P. Green \& Shapiro, 1994, p. 14).

Rationality conceptually varies among RCT scholars (see Wittek et al. (2014, pp. 5-6) for different types of rationality), but the most preferred model of rationality in RCT is bounded rationality. It was constituted to tackle the unrealistic assumptions of models of full rationality, which are that 'individuals are fully informed about all their decision alternatives, the probabilities of their outcomes, and their consequences' (Wittek et al., 2014, pp. 6-7), and that '[i]ndividual decision-makers do not face any cognitive limitations or biases in perceiving or processing this information' (Wittek et al., 2014, p. 7) to calculate cost and 
benefits of alternative options to reach utility maximisation. In this context, models of bounded rationality make two important assumptions:

First, decision-makers are usually not fully informed about all available options: their perception of information is biased through selective attention (framing processes). Second, humans have limited cognitive capacities for processing the information that is available to them: rather than maximizing, boundedly rational actors satisfice- that is, once they detect a course of action that in their eyes is good enough to reach a goal, they won't go on searching for a better one, even if they know that a better solution would be available (Wittek et al., 2014, p. 7).

In Understanding the Process of Economic Change, North (2005, p. 24) accepts these assumptions of bounded rationality but points out that choices are also bounded within a set of beliefs in a world that evolves or changes continuously. This implies rationality shaped by a set of beliefs, which are necessarily creating path dependency in development in terms of crafting institutions. As he highlights, "choices in the present are constrained by the heritage of institutions accumulated from the past" (North, 2005, p. 51), and options out of the path would therefore not be chosen by rational individuals.

RCT is successful in explaining not only individual actions but also collective actions. It elucidates within bounded rationality that individuals seeking utility maximisation may get involved in coordination and cooperation to reach common or group interests or benefits. In The Logic of Collective Action: Public Goods and the Theory of Groups, M. Olson (2002, pp. 133-134) proves that in order to attain a collective good, large groups or organisations can act collectively if they provide positive inducements to encourage individuals to incur costs and if they have the authority and capacity to coerce or punish free-riders. In Governing the Commons, E. Ostrom (2011) shows that even in the absence of an authority to coerce or punish free-riders, individuals are capable of acting collectively to appropriate a collective good from common pool resources and to set rules for how to do so and for how to set or modify those rules.

As for political collective actions such as those based on nationalism or ethnicity, bounded rationality remains inadequate to grasp reality. RCT scholars, for a long time, approached nationalism and ethnicity as instruments by which elites may exploit their group members to further their individual interests. This standpoint is a contradictory one: nationalist or ethnic group members have individual rationalism but they also stupidly follow their manipulative leaders without taking account of their own interests. However, nationalist or ethnic 
collective action may require to take risks of resisting or fighting against another group or a dominant political power despite high costs (Varshney, 2003). For such political collective actions, according to Varshney (2003), the concept of rationality combines two different types: instrumental rationality and value rationality. Instrumental rationality is similar to bounded rationality in that individuals in the group use ethnicity or nationalism to reach their self-interested ends. This type of rationality especially predominates when a nationalist or ethnic movement 'has reached a critical mass, raising prospects of success' (Varshney, 2003). Value rationality explains the origins of an ethnic movement, and its pure form drives individuals to incur the highest costs for their group such as death. ${ }^{1}$ The combination of these two types of rationality shows itself in a struggle among group members how to decide to attain group objectives. It is no wonder that a group member has her own stance about what is valuable, what group objectives are to be and what is to be done to reach them. As for rival intra-group leaders, 'selective retrieval of tradition' is adopted as standard to get support from group members or foster group cohesion and consciousness (Varshney, 2003).

\section{Development}

Pointing to the fact that there are too many but highly contested definitions of development in the literature, M. P. Cowen and Shenton (1996/2005, pp. 2-3) argue that a major source of confusion comes from understanding development 'as an imminent and objective process' (e.g. capitalism develops) and understanding development as what can be achieved by intentional actions of 'a subjective source of action'.

When addressing the development of the West from a historical perspective, it is taken as a natural process or transformation. For example, the transformation from agricultural economy to industrial or urban-based economy, called as the great transformation, is proceeded by two laws pertaining to agricultural production: the law of diminishing return and Engel's law.

The law of diminishing returns holds that if the total size of land remains fixed as populations grow, then increases in returns from farming diminish. Average incomes would consequently decrease, and agrarian societies would fall into poverty. Regional specialisation in agricultural products, the expansion of trade of agricultural surplus on markets, and migration to not-yet-under cultivation lands are responses of agrarian families to counter the effect of the law of diminishing returns (Bates, 2017, pp. 7-8). Agrarian families interact with

\footnotetext{
${ }^{1}$ Varshney (2003) states that the pure form of value rationality is exemplified in suicide bombings and seeking martyrdom. The individuals who get involved in them accept the high costs of their actions such as death and seek to contribute to their common goals.
} 
merchants in towns to sell their agricultural surplus; merchants sell agricultural commodities to urban dwellers. In response to the law of diminishing returns, surplus labour is directed to developing urban areas for employment while families transition to intensive agriculture. The capital accumulation mechanism set up between town and rural areas in this way reflects the historical development of north-western Europe.

According to Engel's law, as incomes rise, food expenditures proportionally decrease in family budgets. The remaining part of the disposable income is spent to purchase nonsubsistence or urban commodities and services, and on a macro-level, the rural sector loses its weight in a country's total gross domestic product (GDP). That is, urban economies characterised by industry and service sectors replace the rural sector (Bates, 2017, p. 8). Here, development implies a natural course of structural changes.

The intentional development actions and approaches increased in importance after World War II and were especially aimed at dealing with developmental problems of the ThirdWorld (Escobar, 1997). The general approach to development was based on western-oriented assumptions, that is, the creation of 'the conditions that were supposed to characterise the more economically advanced nations of the world' were attempted for development (Escobar, 1997).

In the development literature, another source of confusion about development has, since then, arisen out of the 'distinction between the state policy of development and the attempt to empower people, independently of the state' (M. P. Cowen \& Shenton, 1996/2005, p. 2). Particularly, the former has provided states of the Third World with legitimisation and means to achieve disguised political aims, such as aims relevant to nation-building and the removal of what is traditional.

The development as an attempt to empower people goes beyond the concept of economic growth that indicates material welfare. As Kindleberger and Herrick (1977, p. 1) put it, it includes:

the eradication of poverty with its correlates of illiteracy, disease, and early death; changes in the composition of inputs and outputs that generally include shifts in the underlying structure of production away from agricultural toward industrial activities; the organization of the economy in such a way that productive employment is general among the working-age population rather than the situation of a privileged minority; and the correspondingly greater participation of broadly based groups in making decisions about 
the directions, economic and otherwise, in which they should move to improve their welfare.

The developmental efforts in the Third World significantly created adverse results because their design was 'sociologically ill-informed and ill-conceived' (Cernea, 1994). The general approach to development has evolved since then. The disadvantaged groups were selected as the target group to benefit from developmental programmes and investments, undergirded by technical advice of social scientists, which were directed to social structures instead of physical infrastructure; approaches were adopted taking into consideration the diversity and locality rather than taking an ethno-centralism perspective (Cernea, 1994). In recent years, an important development has occurred with the emergence of the multi-stakeholder approach, creating cooperation and coordination across different modes of organisations and facilitating the participation of non-governmental bodies and private actors in decision-making processes and monitoring (Fransen \& Kolk, 2007).

\subsection{Research Questions}

This study focuses on the political economy of development as an intentional attempt made by governments, development agencies, private actors, and non-governmental organisations.

The main aim of the study is to critically assess RCT taking into consideration state formation and development in Turkey as a country with an imperial background. The transition from Empire to a modern republic did not go smoothly. The Kurdish Question, emerged as a result of this transition, has politically evolved over the years and considerably affected security and prosperity of the country. It still remains unsolvable as an ethnopolitical problem. One of the characteristics of this problem is that it has always been interlocked with the less developed SAR which has a high Kurdish density. After the armed conflict between the PKK and the Turkish state, market-oriented relationships and the use of modern agricultural methods started to spread across the region. This period coincided with the neoliberal agricultural transformation of Turkey's agriculture, underscored by the introduction of the Agricultural Reform Implementation Project (ARIP) and the acceleration in government interventions in regional development, mostly within the scope of the SAR. In light of these developments, the research seeks to answer two questions:

Why has Turkey, since 2001, simultaneously implemented both neoliberal agricultural policies and government interventions for agricultural development in the South-eastern Anatolia Region? 
The response mainly lies in changes in Turkey's political economy but specifically in the conflicting relationship between the centre and the periphery and international dealings of the government. After answering this question, we will answer a second question:

How has the simultaneous implementation of neoliberal agricultural transformation and government interventions affected agricultural development of the South-eastern Anatolia Region since 2001?

\subsection{Research Design and Methodology}

This section discusses the methodological aspects of the research. The focus and limitations of the research are discussed. Furthermore, the details of data collection and the sampling method for quantities interviews will be shown.

\subsubsection{Focus and Limitations}

In this section the focus and limitations of the research are discussed. Note that the main observation - namely that the SAR is among the least developed regions in Turkey - is discussed in the background chapter.

This research does not offer an analysis of the sustainability of agricultural development. Sustainability, in general, refers to increasing material welfare without leading to depreciation of the environment at the expense of the wellbeing of future generations. In this regard, Turkey has been improving, albeit slowly, its institutional framework and capability in line with the EU acquis (Oskam et al., 2004, pp. 146-150, 195-196) and cooperating with the affiliated organisation of United Nations to reach sustainable development goals (UNDP, 2018). We therefore assume that agricultural authorities in Turkey, agricultural enterprises (AEs), and other related organisations are gradually improving their activities with regard to sustainable concepts. Our analysis does not cover most aspects of the agricultural relationship between Turkey and the EU or/and other international organisations. As a matter of fact, the direct influence of international organisations over the regional development is limited to financial aid and technical assistance, which will be referred to within the evaluation of project- or programme-based interventions via the poly-centric governance approach in the next chapters.

We focus on agricultural development rather than rural development, taking into account the fact that their conceptual equivalence is no longer accepted in the literature. Rural development requires to develop an understanding about rural milieus and the rural poor. In this sense, the general topics addressed in rural development are to develop rural households, 
various rural non-farm sectors and employment types in rural spatial areas and to offset social inequalities in rural life. Agricultural development however focuses on the development of agricultural sector, so on agricultural policies and institutions and on interactions between different stakeholders such as producers, input providers, intermediaries, buyers, processors, and employment types in an agricultural space (Schejtman, 2008, pp. 141-142). Agriculture and agro-industry have an important role in the SAR's economy. So when the government formulates and carries out economic policies for the region's development, it therefore inevitably needs to take account of the two sectors.

Our research concerns agricultural enterprises in the SAR that engage in modern, marketbased relations, so excluding small agricultural enterprises (SAE) doing subsistence farming. The temporal scope of our analysis chapters spans the period of 2001 to 2017, which witnessed a stark variation in terms of marketisation of agricultural enterprises. Subsistence or semi-subsistence farming had prevailed until the late-1990s, especially in Kurdishpopulated high-elevated areas (P. J. White, 1998, 1999). That is, farmers had mostly or completely cultivated their lands for their own consumption. But unfavourable physical and economic conditions exacerbated by the armed conflict (Jongerden, 2015, pp. 313-351) and diminishing returns as a result of an increasing population ${ }^{2}$ greatly changed the agricultural structure based on traditional farming (Keyder \& Yenal, 2014, pp. 51-53). Traditional farming here refers to subsistence or semi-subsistence farming activities, which are often done within the limits of indigenous knowledge and cultural norms.

This research ignores intra-tribal and inter-tribal relations, which strongly structured the traditional agricultural system of the region in the past but now have a limited impact on agricultural practices. Tribal leaders demonstrated their willingness, already from the 1950s onwards, to become big landholders exercising modern farming practices to generate more surplus. Sharecroppers, who before worked at a tribal leader's service, almost disappeared many years ago as a result of mechanisation (Gürel, 2011), the diminishing returns of dry farming (Uluc, 2007, p. 151), the armed conflict, and the displacements related to dam constructions (Akça, Sasaki, \& Fujikura, 2017; P. J. White, 1998). Consequently, the tribal system has been disintegrating for a long time, and tribal leaders are not able to perform their tradition roles in agricultural production anymore (Uluc, 2007, p. 149). Today tribal leaders

\footnotetext{
${ }^{2}$ Even in the 1970s, Bruinessen (1992, p. 32) ascertained that limited size of land plots and the Islamic inheritance law leading to equal division of land among sons resulted in insufficient plot sizes for families to earn their livelihood and sustain their lives through farming. This phenomenon has induced migration to urban areas from rural ones, which is still ongoing to this day (Turkish Statistical Institute, 2018a).
} 
are largely wealthy, modern big landowners, who reside in urban areas involved in commerce, service and industrial sectors. They are able to keep their power and network as long as they provide their members with economic benefits, employment and social status (Gultekin, 2013).

The research also does not pay attention to gender issues in the agricultural sector. The labour force participation rate of women in the SAR is the lowest in Turkey (Asik, 2012). Furthermore, cultural norms and values associated with patriarchy make communication with women very difficult for a male outsider. Whenever I was invited by a farmer to his house, female members of his family immediately left the living room until my departure. Men, given the strong patriarchal values prevalent, are still key decision-makers for most agricultural activities.

The problem of insecurity in the SAR was a major limitation for the fieldwork. Southern boundaries of the region have long been susceptible to the threat of violence from the battlefields in Syria. Moreover, visiting high-conflict areas became more dangerous when Turkey and the PKK ended the ceasefire after the June 2015 general election. Following advice and warnings by local people, I cancelled or shortened potential dangerous visits.

Another major limitation relates to incomplete, insufficient, and somewhat unreliable or outdated statistics that are released by the Turkish Statistical Institute, especially those that supposedly capture data at a regional, provincial or town level and during the period of the armed conflict. The recent literature about the SAR's economy does also not offer us econometric studies to make inferences for our analysis. All impel us to conduct qualitative data collection and analysis.

\subsubsection{Data Collection and Methodology}

This study is predominately based on qualitative research methods using the inductive approach. Basic calculations on data provided by different sources of statistics further contribute to the analysis. In terms of epistemology, the research rests on interpretivism, seeking to capture the social world through the interpretations made by its members. With regard to the ontological position, the research can be defined as constructionist. According to Bryman (2012, p. 380), constructionism "implies that social properties are outcomes of the interactions between individuals, rather than phenomena 'out there' and separate from those involved in its construction." The research recognises "the role of individuals in the 
construction of social reality' (Bryman, 2012, p. 30) and seeks to understand experiences, perceptions, viewpoints and values of local actors via qualitative research.

Several data sources were used, including statistics and relevant documents from public organisations, i.e. reports of past policies and experiences, policy and strategy papers, plans and projections. These allowed an evaluation of national, regional and provincial organisations and their policies through a qualitative content analysis. I combined this primary data produced by organisations with the secondary sources produced in relevant areas by researches.

Another data source was semi-structured qualitative interviews with authorities in various organisations. The selection criteria for the content of these interviews were as follows: I chose specific discussion topics for interviews, and then, several key questions were formulated to create an interview guide as a basis. During the interviews, the interviewer had the possibility to change the order of the questions, ask follow-up questions, promptly create additional questions and encourage the interviewee to clarify and expand on his or her statements or arguments (Arksey \& Knight, 1999, p. 7; Robson, 2011, p. 280). When unanticipated relevant themes emerged from these interviews, those were added to the questionnaire and asked to the next interviewees. The interviews enabled a deeper understanding of the issues discussed but came with their challenges as well. Arranging interviews with an interviewee and conducting, transcribing and analysing them were all time consuming. Interviewees holding back their responses somewhat restricted the amount of data collected (Robson, 2011, p. 281).

Different interview questions to different interviewees were asked according to their locale, the role of their organisation in agriculture, differing themes and types of agricultural crops cultivated. The interview questions are presented in Appendix 1a in relation to the second main research question.

I occasionally met persons in a restaurant or a minibus, who were willing to get into conversation. After I became acquainted, I asked questions relevant to my research topic and took notes. This more informal and conversational type of qualitative data collection was also applied whenever farmers had negative attitudes about interviewing. Some farmers questioned my position, thinking of me as being linked to the state. To illustrate, when I went to villages in the central district and Hasankeyf of Batman, they were experiencing a disagreement with the state about the expropriation of their lands to be flooded as a result of 
Ilisu Dam and its reservoir. This problem had been compounded by an antagonism that the farmers felt against the destruction of Kurdish heritage and the resumed warfare in urban areas of the region after the $7^{\text {th }}$ June general election. It was difficult to persuade them that I had no ties with the state; the conversation was brief and tense. Added to the acquired data from the interviews were notes from conversation with the people (i.e. farmers) who reside in the region, statistics from different organisations, and primary and secondary sources.

To reply the second research question, another data collection method employed was the focus group discussion with farmers. This technique is important for encouraging discussions and challenges between the participants and helps a researcher to understand what participants think about a certain case or topic, and how they interpret a certain phenomenon and construct meaning around it. The researcher can therefore understand the social world in a more naturalistic and practical way (Bryman, 2012, pp. 503-504). The main difficulties are that the focus group technique is more time consuming than individual interviews because of the longer transcription process; that the formation of focus groups is more arduous; and that the management of a focus group is a demanding task because of the possible existence of dominant or reserved people in a group (Bryman, 2012, p. 504). The questions that were asked to the focus groups are presented in Appendix $1 \mathrm{~b}$.

In the next section, we will display detailed information about sampling for data collection and conducting of the fieldwork.

\subsubsection{Sampling for the Data Collection and Conduct of the Fieldwork}

The primary aim of this section is to describe how the fieldwork was designed and implemented. The fieldwork lasting over 4 months was performed in six separate periods as seen in Table 1.1 .

\section{Locale}

The SAR was chosen as the main locale to be examined because it is a relatively less developed region in an urbanised country, in which market relations in agriculture have considerably bourgeoned for two decades. The political economic circumstances the region has faced in that period allow us to evaluate the effects of agricultural liberalisation in conjuncture with government interventions under a development programme, thus allowing for a critical assessment of the key arguments made by RCT scholars. 


\begin{tabular}{|l|l|}
\hline Time Pe riod & \multicolumn{1}{|c|}{ The Purpose of the Fieldwork } \\
\hline August 2014 & $\begin{array}{l}\text { Two weeks were spent to contact, arrange and conduct } \\
\text { interviews with authorities at the Ministry of Food, Agriculture } \\
\text { and Livestock and the General Directorate of the Chamber of } \\
\text { Agriculture }\end{array}$ \\
\hline September 2014 & $\begin{array}{l}\text { Nearly a month was spent to arrange and conduct interviews } \\
\text { with authorities in agricultural directorates and other } \\
\text { organisations in Adiyaman, Gaziantep and Diyarbakir. Several } \\
\text { farmers were interviewed as well }\end{array}$ \\
\hline December 2014 & $\begin{array}{l}\text { One week was spent to contact, arrange and conduct } \\
\text { interviews with firms that operate in agricultural information, } \\
\text { technology and marketing system }\end{array}$ \\
\hline April-May 2015 & $\begin{array}{l}\text { Over a month was spent to contact, arrange and conduct } \\
\text { interviews with agricultural directorates and other agriculture- } \\
\text { related organisations in Mardin, Sanliurfa, Kilis, Gaziantep and } \\
\text { Diyarbakir }\end{array}$ \\
\hline July 2015 & $\begin{array}{l}\text { Nearly a month was spent to conduct interviews with farmers } \\
\text { in various cities and authorities in regional administrative bodies }\end{array}$ \\
\hline August 2015 & $\begin{array}{l}\text { Around ten days were spent to conduct interviews with farmers } \\
\text { in various cities }\end{array}$ \\
\hline
\end{tabular}

Table 1.1The Brief Timeline of the Fieldwork

Agricultural wise, the SAR is far from a homogenous region. It includes different methods of agriculture (i.e. rain-fed and dry-land farming), different micro-climates, different crop types, various scales of agricultural enterprises in plains and mountainous areas, etc. With such characteristics, specific locales had to be selected in order to represent agricultural development of the region as complete as possible. Incidentally, it is worth noting that we focus on agricultural crop production (81.8\%) far more than animal products $(18.20 \%)$, taking into account of their shares in the total value of the regional agricultural GDP in 2017 (Turkish Statistical Institute, 2018a).

Prior to my fieldwork, provinces and towns were selected to be visited, on the basis of the 2012 statistics of agricultural crop production ${ }^{3}$ ensuring a normal season not affected by drought or economic recession. Therefore, visits were made to the places where agricultural production is relatively high. For example, Kahta and Central District of Adiyaman were important fieldwork destinations with cereal and legume production accounting for over 60 per cent of the total production of those crops at the provincial level (Turkish Statistical Institute, 2018a). Nizip of Gaziantep was also visited since that town was ranked first in the production of olive and pistachio in the region (Turkish Statistical Institute, 2018a).

\footnotetext{
${ }^{3}$ I used the Vegetative Production Statistics published by Turkish Statistical Institute (2017a).
} 
As many questions regarding the various crop types as possible were asked during these visits. Wheat, barley, maize and cotton are the prevalent crops cultivated in the region, however some provinces or towns produce crops such as olive, pistachio, red grape, pomegranate. These areas were also visited. For instance, Nizip of Gaziantep was visited to better understand agricultural production of pistachio and olive, Kilis for red grape, towns in Sanliurfa for red pepper and Adiyaman for tobacco and pomegranate. Farmers were interviewed exercising different methods such as rain-fed and irrigated farming methods and farming in different geographical spaces such as plains (i.e. Harran of Sanliurfa) and mountainous areas (i.e. Lice of Diyarbakir). The entire list of the towns visited can be seen in Appendix 2a.

In our fieldwork, I furthermore sought to visit towns deeply affected by the Kurdish Question. Identifying towns with high conflict rates was necessary and therefore I used 'the Global Terrorism Database' - created by National Consortium for the Study of Terrorism and Responses to Terrorism. ${ }^{4}$ I cross-checked all the violent incidents listed in the database with national newspapers and Serxwebun, a monthly magazine published by the PKK, in order to find out in which town which incident took place. As the data of 1993 is missing in the database, Serxwebun was used to compensate for this gap in the data. The reliability of data from Serxwebun in turn is cross-tested by comparing it with national newspapers published in Turkey and the data derived from the Global Terrorism Data. Hence, I ended up putting together a list of the names of towns and the number of violent incidents occurred in each town.

In Appendix 2b lists all the areas with the highest level of conflict in the region between 1984 and 2014 in terms of incident frequency. The towns marked in yellow in the list were visited for this fieldwork. The most important limitation for travelling was security issues that arose during the fieldwork. Whilst attacks made by the Islamic State of Iraq and al-Sham prevented me from seeing towns along the Turkey-Syria border, warnings of local people also deterred us from travelling to pre-determined destinations in high-conflict areas of Siirt and Sirnak because of rising violence between the state and the PKK after the general election on $7^{\text {th }}$ June, 2015.

\footnotetext{
${ }^{4}$ For information, look at the website of the database, https://www.start.umd.edu/gtd/
} 


\section{Population and the Selection of Participants for Interviews and Focus Groups}

There is an obvious link between sampling and population because a sample is chosen from population. The main reason for sampling is the impossibility of scrutinising the entire population for the purpose of the research conducted (Robson, 2011, p. 270).

The population of our research consists of farmers in the SAR who sell their crops to agricultural commodity markets; bureaucrats, officials and experts in central and regional agriculture-related governmental organisations; experts and farmers in regional farmer associations or cooperatives; people working for extension and advisory bodies and industry and trade associations; academics in regional research organisations and universities who are interested in agriculture-related sciences; and persons in the administration of agro-industrial companies.

In our study, persons in agriculture-related organizations were interviewed through the snowball sampling method. These organizations were divided into three groups: high, medium and low-level organizations. For this research, the high-level category includes the Ministry of Agricultural and Forest (MOAF) in Ankara, the capital city of Turkey. Unfortunately, some of the lower-level officials within these high-level categories who were available for interviewing were constrained in the amount of knowledge they had (and were willing to provide). Officials with higher positions were approached but were not available for communication and interviews. Only one expert of the MOAF in Ankara accepted the request for an interview. Some of the high level category officials rejected interviews for fear of possible political-natured accusations. The same problem was faced as I interacted with most of the medium-level organisations in the region. Most local agricultural directorates, public research bodies and other public organisations made me to follow a long process obtaining permissions from various authorities in order to conduct interviews. Authorities in chambers of agriculture, commerce and industry too were reluctant in allowing interviews for political reasons.

Low-level organisations, including farmer unions, cooperatives, and agricultural enterprises were also interviewed. Friends who lived in the region helped me to find and visit farmers and talk with Kurdish-speaking interviewees. I also followed up suggestions made by regional public agricultural organisations and farmer associations or cooperatives for potential farmers to interview. To mitigate potential bias, I also got recommendations from local ordinary people in friendly conversations to find proper farmers. Finally, social media 
was used to contact the interviewees with whom I later conducted interviews via phone or email.

Information about all the interviewees can be found in three tables in Appendix 3, such as the names of organisations interviewed, the locales of the farmers interviewed, the types of interviews made with the farmers and the dates of interviews. Nearly all of the interviewees asked for anonymity for political reasons, especially with regard to the Kurdish Question. Given the escalating political relation between the Turkish state and the Kurdish political movement after June, 2015, anonymity was deemed necessary, even where interviewees did not ask for it.

I also kept the names of officials anonymous for (different) political reasons. A corruption scandal revealed in 2013 was portrayed by the government as an attempt to remove them from power. They consequently targeted the Gulen movement- now considered a terrorist organisation by the Turkish state - and started to purge police officers and judicial officials who were allegedly linked with the movement, and changed legal frameworks to enhance the state's position. This incident caused stress for state officials, irrespectively of whether they had links with the Gulen organisation. At the start of the fieldwork, some of the officials clearly articulated their concern; obviously, many officials seriously questioned my political position and/or motivation. However, a number of them were willing to response to my questions in a frank manner, paving the way for highly informative interviews. Ten months after I had finished the fieldwork, a (failed) coup attempt took place on the night of $15^{\text {th }} \mathrm{July}$, 2016. The government again initially targeted members of the Gulen movement but then expanded their net to include all their opponents, purging a vast number of officials from their positions. Avoiding putting the lives of the interviewees in jeopardy, we conducted the interviews on an anonymous basis, and I kept information about their departments or positions as vague as possible.

\section{The Sampling Method for Individual and Focus Group Interviews with Farmers and the Categorisation of Agricultural Enterprises in the SAR}

The necessary data from farmers was gathered through interview and focus group techniques by following the stratified purposeful sampling method. By referring to Patton (2002, p. 240), Cohen and Crabtree (2006) explain:

[Stratified samples] are samples within samples and [...] purposeful samples can be stratified or nested by selecting particular units or cases that vary according to a key 
dimension. For example, one may purposefully sample primary care practices and stratify this purposeful sample by practice size (small, medium and large) and practice setting (urban, suburban and rural). Stratified purposeful sampling is different from stratified random sampling in that the sample sizes are likely to be too small for generalization.

With the stratified purposeful sampling method, the main aim is '[to] capture major variations rather than to identify a common core, although the latter may emerge in the analysis' (Palinkas et al., 2015). I determined agricultural production as the main activity and stratified agricultural enterprises according to both crop types and location at first and then their scales (small, medium and large). In terms of location, agriculture-dense areas in each province and high-conflict areas were chosen and visited as mentioned before.

An important criterion for determining the scale of an agricultural enterprise is the income level. As agricultural enterprises in Turkey tend not to keep accounting records, it is the size of land it has that is a fairly good indicator of the enterprise's scale. The minimum and the maximum sizes of a SAE used for our analysis were taken from existing definitions and a list relying on a piece of legislation- the Law on Soil Preservation and Land Utilization, and its amendments. The law prohibits the division of any agricultural land as a result of inheritance in a manner that would make it smaller than a certain size. This relates to the minimum size of agricultural enterprises to sustain it economically, and it, typically, is more than 20 decare (da) for farming lands and 5 decare for orchards and vineyards in Turkey ("The Law on Amendments on the Law No.5403," 2014). The maximum size of a SAE is also defined by law on a provincial and township level in respect of land utilisation ("The Law on Amendments on the Law No.5403," 2014). Table 1.2 shows the reference size for SAEs.

There is no consensus in the literature about reference size of medium (MAEs) and largescale agricultural enterprises (LAEs), and generally no categorisation of these in relation to land utilisation. ${ }^{5}$ Based on our consultations with officials during the fieldwork, I defined MAEs and LAEs as can be seen in Table 1.2. However, there was no general consensus about the sizes of orchards and vineyards determined by the MOAF. Note that those in the table may be attributed to AEs that solely cultivate pistachio as this crop generally provides AEs

\footnotetext{
${ }^{5}$ Large AEs are considered as those with total land size above 1000 decares in the study of M. Öztürk (2012, p. 82). Medium-scale AEs are defined between 200 decares and 999.99 decares and large farms are above 999.99 decares according to Eurostat (Eurostat, 2017). According to Unal (2012), small AEs own land between 1 decare to 20 decares, medium AEs 20 to 199.99 decares, large AEs 200 to 499.99 decares, very large AEs above 500 decares. In fact, large AEs can be taken as those with land size above 500 decares in this study if we exclude the category of "very large AEs".
} 
very high prices that may not be seen in another crop type. For example, owning a vineyard of 15 da for grape cultivation is not enough to be a MAE as the income it offers is very low as I was told during the fieldwork. Nevertheless, a number of the farmers that were interviewed owned small sized orchards and vineyards along with farming lands. In such cases, I asked them questions to assess their agricultural income levels and compare them with the others in order to place their AEs in the correct category. Appendix 4 gives information about farmers and their AE size, and how focus groups were constituted.

\begin{tabular}{|c|c|c|c|c|}
\hline Type of AE & Reference Value & $\begin{array}{l}\text { Rain-fed } \\
\text { Farming }\end{array}$ & $\begin{array}{l}\text { Irrigated } \\
\text { Farming }\end{array}$ & $\begin{array}{c}\text { Orchards } \\
\text { \& Vineyards }\end{array}$ \\
\hline \multirow{2}{*}{ SAE } & Minimum Size & \multicolumn{2}{|c|}{$20 \mathrm{da}$} & $5 \mathrm{da}$ \\
\hline & Maximum Size & $152.32 \mathrm{da}$ & $66.1 \mathrm{da}$ & $10 \mathrm{da}$ \\
\hline MAE & Size Range & $152.33-500 \mathrm{da}$ & $66.2-216.97 \mathrm{da}$ & $10.1-32.82 \mathrm{da}$ \\
\hline LAE & Size Range & $>500 \mathrm{da}$ & $>216.97$ & $>32.82 \mathrm{da}$ \\
\hline
\end{tabular}

Table 1.2 The Reference Sizes of Different Types of Agricultural Enterprises

\subsubsection{Data Analysis}

A thematic analysis was used for the qualitative data from the semi-structured interviews and focus group interviews. Prior to conducting the fieldwork, the main themes and sub-themes were selected through knowledge gained through the literature review and from document analysis. The fieldwork was done in three steps. After conducting the interviews, these were transcribed and then read several times to check for gaps in data and subsequently establish an index of themes. Gaps detected sometimes gave rise to new interview questions during the next round of fieldwork. Through this, saturation was ultimately reached, and confidence about the index of themes improved. After the fieldwork was completed, the Nvivo computer-assisted qualitative data analysis software was used for coding and classifying the data under sub-themes and themes. It must be noted that the Nvivo cannot make decisions about how to derive codes from the data and categorise them and how to interpret data. In other words, all these tasks are to be fulfilled by researchers (Bryman, 2016, p. 602).

Our data analysis was mainly based on qualitative data but some quantitative analysis also took place. The statistics published by the Turkish Statistical Institute (and to a lesser extent by other statistical data institutions) were tapped for simple calculations such as proportional changes and average growth rates. The main aim was to contextualize and triangulate evidence derived from the qualitative data analysis. 


\subsubsection{Ethical Considerations}

Given that the political disagreements and rivalries have become fierce in Turkey especially after 2013, and that the Peace Talks collapsed after the general election on $7^{\text {th }}$ June 2015 , though interviewees completed a consent form (as seen in Appendix 5) to waive anonymity, their identities or names are not stated in this research. In line with the university's ethical standards, every interviewee was fully informed of the various aspects of the research through the research information document as seen in Appendix 6.

\subsection{Thesis Structure}

The thesis has two main parts. In order to critically assess RCT, the first part is concerned with state formation and development and the second part focuses on neoliberal agricultural policies and agricultural development, taking into consideration the dichotomy between simultaneously pursued market-based policies and government interventions.

The first chapter introduces the context of the study, the knowledge gaps identified in the literature, the key concepts and research questions, and explains methodological issues and how the fieldwork was conducted.

The second chapter discusses how RCT deals with the matter of state formation and development by taking different cases from developed countries and less developed former colonies. After introducing the key concepts, the chapter will compare the Ottoman Empire with England and France to better understand and appreciate the institutional differences shaping their development and state formation processes. This discussion enables us to understand how Turkey's state formation is different than those of less developed countries and how the institutional heritage obtained from the Ottomans has affected state formation and development. Conflicting relationships between the centre and the periphery will be discussed to critically assess and test RCT.

The third chapter deals with the Kurdish Question and the Kurdish political movement as political collective action. After the key concepts of social capital are introduced, the chapter focusses on how Kurdish ethnic social capital has created a long-standing political collective action, which has frustrated nation-building of the Turkish state. The military narrative and the development narrative as efforts of the Turkish state to frame the Question are also examined.

The fourth chapter is concerned with Turkey's political economy and agricultural policies, as shaped between 1980 and 2001, a period involving efforts to apply neoliberal policies with 
the occasional diversion. Furthermore, information about the GAP, its changing content in line with changes in approaches to development at the global level and information about the SAR's agriculture will be displayed. Our argument that the SAR is a relatively less developed region in Turkey will be presented in this chapter.

The fifth chapter answers the first research question. It deals with Turkey's political economy since 2001 and evaluates how the conflicting relationship between the centre and the periphery has affected the intra-elite and class-based relationships within the dominant coalition and how international dealings have been employed to foster political power. The effect of these relationships has been increasing government interventions in the SAR's agricultural development. The implementation of neoliberal agricultural policies and development interventions seems contradictory, but the chapter shows that the combination of these policies comes from the political conflicts discussed.

The second part of the thesis involves the sixth chapter and the seventh chapter. The sixth chapter is concerned with neoliberal agricultural transformation in less developed countries. It engages in discussions about neoliberalism, neoliberal economic policies and the relationship between RCT and neoliberalism. After presenting how RCT approaches agricultural policies, it provides a critical discussion of RCT and neoliberal agricultural policies.

The seventh chapter responds to the second research question and displays the findings of the fieldwork to critically assess how neoliberal agricultural policies have affected the SAR's agriculture since 2001. Thereafter, it argues that development interventions in the form of projects and programmes can produce good results if they are based on the poly-centric governance approach, and takes successful and unsuccessful examples to prove the assertion.

The eighth chapter summarises the content and the findings of the study. All research questions are revisited in this chapter. In light of the findings, it gives suggestions for those who study in state formation and development. 


\section{PART 1: STATE FORMATION AND DEVELOPMENT \\ Chapter 2: State Formation and Development from the Aspect of the Conflicting Relationship between the Centre and the Periphery}

\subsection{Introduction}

The chapter critically assesses RCT, mainly addressing theoretical arguments about state formation and development in Violence and Social Orders: A Conceptual Framework for Interpreting Recorded Human History (Violence and Social Orders henceforth), written by North et al. (2009), and in Prosperity and Violence (2001) and the Development Dilemma (2017) written by Bates. These RCT scholars deeply examine developed Western countries and/or colonial countries to prove their theoretical arguments. The chapter however points to that an elaborate investigation into the countries that own imperial political economic background is neglected.

To begin with, we will address how RCT deals with the matter of state formation and development by taking different cases from developed countries and less developed countries as former colonies. In further sections, we will take the case of Turkey to discuss how she matches with and differs from other countries, emphasizing institutions that were inherited from the Ottoman Empire. In a sense, the case of Turkey will also offer us an insight to carry on further discussions on the Kurdish Question and development in the next chapter.

\subsection{State Formation and Development in Rational Choice Theory and Its Critical Appraisal}

This section is primarily concerned with comparing development pathways of different types of countries to introduce the main concepts used in our research and critically assess arguments made by Robert Bates, which fall into RCT. Bates mainly compared north-west European countries with mostly African and Latin American countries to - generally successfully - explain why less developed countries have failed in achieving development. However, not all developing countries are former colonies; rather, some have a deep imperial background, which is still affecting their society and political terrain today. Turkey is a perfect example of such a non-colonised developing/transitional country, inheriting an institutional legacy from the Ottoman Empire. We shall expand on this point throughout this chapter and use it to critically approach Violence and Social Orders: A Conceptual Framework for Interpreting Recorded Human History (Violence and Social Orders henceforth), written by North et al. (2009), who examine development and state formation in 
north-western countries in detail but neglect non-Western less developed countries with imperial backgrounds.

We will show that the Ottoman Empire was one of the strongest powers in Europe/near-East during the late Middle Age and most of the early Modern period but could not shift its economy from agriculture to an urban industry, as a result of her institutional characteristics. If we compare France, England and the Ottoman Empire, we can understand how different political economy characteristics have affected Turkey's development pathway.

Assuming that actors act rationally, Bates (2017, p. 117) argues that regional diversities relying on economic, political, ethnic and cultural differences create different regional rationalities and shape political terrains and the use of power. Elites at the centre, who strive to hold power under conditions created by strong regionalism, generally find cooperating with regional actors a less effective strategy than practising coercion to suppress or discourage them. The use of coercion, however, can cause political instability and can lead to development failures.

In response to Bates, we shall assert that a high degree of centralisation - characterised by an excessively powerful, narrow circle of elites - amalgamated with the use of coercion (or threat of violence) restricts the political access and participation of those who fall out of the central power. Experiencing intimidation and calculating risks, costs and payoffs of an uprising and social disorder, they are forced to opt for regionalism to increase their benefits. Local actors and groups, despite intimidation, sometimes fight to gain political access to the central power or to acquire more power. This mostly incites elites at the central power to exercise even more coercive acts to dissuade them from doing this. Alternatively, members of the central power face requests from regional elites or groups for participating in the central hierarchy when they are to extend their political base to the people in the periphery. Political instability and lack of development could consequently occur when this struggle is repeated or prolonged.

What we have told above, too, holds for peripheral movements against the political centre. In fact, there is a nuance between the concepts of regionalism and periphery. Regionalism involves political approaches that are shaped by political-economic and institutional characteristics peculiar to a region as a specific geographic area. The concept of the political periphery includes regionalism but also the other approaches (and positions) that promote 
resistance or attack to the political-economic centre by cutting across the entire population and territory of the political unit.

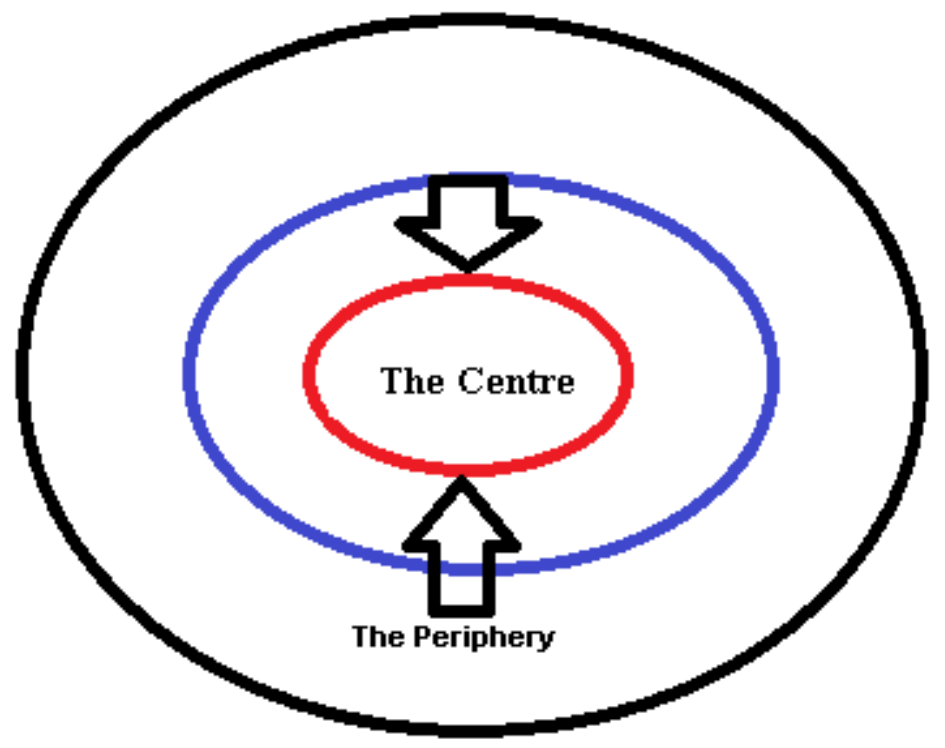

Figure 2.1The Centre and the Periphery

Figure 2.1 illustrates the tense relationship between the centre and the periphery. The red circle represents the elites with the strongest position who restrict access to valuable resources (i.e. land, labour, capital) and activities (i.e. trade, education, military) to create and appropriate rents. The blue circle encompasses the dominant coalition. The area between the blue and the red circle covers the elites who have (some) access to the centre; they can obtain privileges and rights in return for their support and resources. Another part of their political importance stems from their ability to influence over the people in the periphery. Some of those elites (e.g. the aristocracy in France) revert to regionalism; others (e.g. the bourgeoisie prior to the French Revolution) struggle for more or complete access to the centre (kept by the monarch of France). The area between the blue and the black circle represents the people oppressed in the periphery (e.g. the peasantry, craftsmen, petty traders, wage-earners, journeymen, etc. before the French Revolution who later politically supported the bourgeoisie against the monarch and the aristocracy), who can fight against the dominant coalition, sometimes allying with a specific group of elites in it.

This diagram is a simplification; in reality the boundaries are blurry, and the characteristics of interactions and ties between the three groups are more complex, varied and stratified. This interpretation differs from that of North et al. (2009), who find transformation from "limited access orders" to "open access orders" in intra-elite interactions, giving no role for the people 
in the periphery. ${ }^{6}$ In their opinion, in limited access orders powerful individuals coming together for common interests have established "a dominant coalition in such a way that limits violence and makes sustained social interaction possible on a larger scale" (North et al., 2009, p. 13). According to North et al. (2009, p. 17), systematic rent-creation through limited access is a useful means for elites not only to be generating wealth but also to control violence. Their approach however ignores the reaction of the people in the periphery against the negative effects of rent creation among elites. More so, the periphery could also be used by elites to challenge the dominant coalition or central power, reflecting ongoing changes in intra-elite power balance.

If the result of the competition between different groups of elites is to create "impersonal relationships", "perpetually lived organisations in the public and private domains" and "the consolidated control of the military" by the government accountable to the elites, then "the door-step conditions" to an open access order are met (North et al., 2009, pp. 151-152). ${ }^{7}$ The open access order will be later attained when the elites believe that the only way to protect their impersonal rights is "allowing citizens the right to participate [...] to ensure the civil and economic rights all citizens enjoyed" (North et al., 2009, p. 192). This order is one where rent is created and absorbed quickly to reap benefits under political and economic competition, leading to creative destruction resulting (possibly) in secure stable political economic development. Turkey can be deemed as a limited access order that has not satisfied the conditions of the door conditions to proceed to an open-access order. The competition between elites has been affected by the reactions from different groups in the periphery but in turn not led to an open access order.

North et al. (2009, p. 194) state, "the threat to stability and order in a natural state usually came from elite factions within the dominant coalition that sought to use violence or coercion to gain control of the political system". There is a missing part here: the threat from a group of people in the periphery. We will see that political and economic pressure that separately

\footnotetext{
${ }^{6}$ According to North et al. $(2009$, p. 2), "the limited access order or natural state emerged in the first social revolution. Personal relationships, who one is and who one knows, form the basis for social organization and constitute the arena for individual interaction, particularly personal relationships among powerful individuals. Natural states limit the ability of individuals to form organizations. In the open access orders that emerged in the second social revolution, personal relations still matter, but impersonal categories of individuals, often called citizens, interact over wide areas of social behaviour with no need to be cognizant of the individual identity of their partners [...]. Although elements of the second revolution have spread everywhere, especially technology, most contemporary societies remain natural states."

7 The importance of meeting the door-step conditions is related to turning "individual elite rights" into "impersonal elite rights", more secure than the former because they "are defined as commonly shared rights rather than personal prerogatives" (North et al., 2009, p. 191).
} 
comes from Kurds and the conservative people has helped the corresponding elite groups to reap more benefits, or to increase their power in the dominant coalition (or even the centre) to re-structure it. We shall discuss in the case of Turkey how intra-elite relationships have developed and transformed within the dominant coalition, and how the periphery has influenced those relationships.

In Violence and Social Orders, North et al. (2009) generally focus on western European countries and the US but pay no attention to countries in the Third World with imperial or colonial background. These countries are mainly deeply divided along identity lines, which allows the development of intra-elite trust as far as maintaining the dominant coalition but low levels of generalised trust among people (Diamond, 2010). This prevailing phenomenon obviously obstructs the transition to open access orders by denying the development of impersonal social relations and perpetually lived organisations.

In the next section, we shall compare development pathways of France and England at first and those of colonial countries later. Finally, we expand on what we have said by addressing development and state formation in Turkey.

\subsubsection{The Cases of England and France as Developed Countries}

Our primary purpose is to discuss RCT by critically assessing arguments made by Robert Bates in Prosperity and Violence (2001) and Development Dilemma (2017) and to underpin the theoretical concepts introduced in the previous section with examples and explanations. We shall briefly present how Bates explains, within the context of political economy, the differences between France and England.

Both the countries had started the great transformation in the same period, which would pave the way for the emergence of the central states, but only England succeeded in entering the industrial revolution at the end of $18^{\text {th }}$ century. Regionalism and its effect on politics and development are seen by Bates as explanatory for the implementation of different development policies in France and England, and resultant disparities in their developmental outcomes. Our critical discussion is focusing on the relationship between the degree of centralisation (the dominance of elites and classes at the centre and the dominant coalition) and regionalism or peripheral movements, and the effects of this relationship on the use of power and development. This discussion provides us with a theoretical understanding to be used for interpreting the political economy of Turkey. 
The aforementioned responses to the law of diminishing returns increased prosperity but simultaneously insecurity through the private militarisation of rural households, which sought to seize the properties of others (Bates, 2001, pp. 53-56; 2017, pp. 16-18). Some kin groups surpassed others over time and established ruling lineages (Bates, 2001, p. 56), which would satisfy increasing demand from rural elites for peace due to unbearable cost of violence (Bates, 2001, p. 63; 2017, pp. 18-22). As a result, the need for justice among kin groups to increase wealth by rent-creation outweighed the use of violence and helped ruling lineages to found the central states of France and England in the Middle Ages, with a centralised justice system. Their increased central power allowed them to end the provision of private security and militarisation by repressing and seducing rural elites (Bates, 2001, pp. 65-68; 2017, pp. 14-24).

Though they both had successfully started the great transformation in the same period, France later dropped behind England in development over centuries. One of the main arguments proposed by Bates $(2017$, pp. 27-32, 46-48) is that the relatively homogeneity of England as compared to regionalism in France - based on cultural, political and economic differences divergently shaped their political terrains and their ways of using power and framing policies and consequently led to different developmental outcomes.

In terms of shaping political terrain and the way of using power, after conquering England in one attempt, the Normans took control of a unified polity, greatly replaced the Anglo-Saxon landed elites with Norman nobles and allowed them to participate in decision-making processes (Bates, 2017, pp. 27, 30; Perry, Chase, Jacob, Jacob, \& Laue, 2013, pp. 235-236). In contrast, the French monarch conquered part of France and undermined or negotiated with others owning different cultures to secure his control over the country, in which regional economic differences also considerably prevailed (Bates, 2017, pp. 28-30). As a result, England owned a relatively homogenous political terrain that considerably allowed a broad consensus between different interest groups in shaping policies and determining outcomes. France, however, possessed a contrasting political terrain characterised by cultural, political and economic diversity, in which the monarch negotiated with regional elites and their assemblies one by one (Bates, 2017, pp. 35-36; Mann, 2005, pp. 479-480) or blocked their participation in decision-making via assemblies as considering himself more powerful (Mann, 2005, p. 476).

England and France differed from each other in framing policies, so pursued different development pathways. When the kings in England confronted the financial imperative of 
conducting wars, they were to cooperate with urban interest groups, as city centres were highly protected and offered them exiguous profits from usurping urban assets and properties. This "alliance" enabled merchants and manufacturers to participate in decision-making processes and obtain empowerment to regulate markets in return of supplying financial resources to the monarchs for campaigns (Bates, 2001, pp. 58, 60-62). The "alliance" between the monarch, large landholders and urban interest groups was established to perform collective actions at the national level for deriving collective rents from military victories, and helped the introduction of policies creating incentives for healthy development (Bates, 2017, pp. 32-48). ${ }^{8}$ In a nutshell, the English monarch exchanged with different interest groups the political participation in state affairs for financial support (Bates, 2017, p. 37), by which political incentives were created, conducive to high level of political and economic development.

As for France, landed elites at times gathered their forces to curb the power of the French monarch, thus to protect their assets, fiscal authority and regional power (Bates, 2017, p. 31; Rosenthal, 1998, p. 65); yet, their political quiescence was exchanged for privileges to access productive resources and exemption from taxes (Bates, 2017, pp. 37,42). ${ }^{9}$ Given that taxation was a vital issue in the birth of representative assemblies, when tax exemptions granted to the landed elites, the king did not feel committed to base his decisions on the General Estate (Mann, 2005, p. 479). The monarch then focused on urban consumers in Paris, the political heart of the country, to avoid urban uprisings by keeping food prices low. Rural producers, however, were confronted with the disincentives created by low-priced food. They, therefore, had an aversion to expanding their production with new methods, led to low increases in agricultural productivity and agricultural income, and in turn hampered urban economic development (Bates, 2017, pp. 38-43).

In essence, Bates's argument is that regional diversity caused less development outcome and state failure in France, but relative homogeneity paved the way for economic and political development in England. However, not regional diversity but highly centralised power, inherently incorporating restrictions on political access to decision-making, leads to

\footnotetext{
${ }^{8}$ For example, the monarch, in return of political support, created incentives for producers and merchants, by supporting export, banning import, avoiding policies to keep food prices low and improving land rights in favour of large landholders (Bates, 2017, pp. 32-48).

${ }^{9}$ To finance his wars, when the French king focussed on regions, he encountered regional resistance guided by assemblies and bureaucracy, and thus applied to borrowing money from public organisations and to selling the right to collect taxes to financial capital owners (Bates, 2017, pp. 43-46). Where the monarch could not repay debts, the national economy faced a downward spiral of crisis due to rising costs of borrowing and worsening financial positions of the public organisations that had owed money to the monarch (Bates, 2017, pp. 43-46).
} 
regionalism that hampers development. Given that federalism is a system of government based on regionalism, developed countries with a federalist polity characterised by relatively high diversity ${ }^{10}$, such as the US, Canada, Switzerland and Belgium, are clearly contrasting examples to his argument. Bates clearly makes no attempt in understanding development to discuss the relationship between regionalism and the degree of centralisation that represents the political strength of the centre. He only touches upon the issue with few words (Bates, 2017, p. 117):

Long conditioned to think of Absolutism as absolute and France as "statist" and therefore unitary, I was surprised by the degree to which the nation's politics was shaped by its regions. In France, regions were powerful; indeed, they were so powerful that they shaped the manner in which those at the center employed their power.

A conceptual relationship can be regarded between absolutism as the highest degree of centralisation and unitary from a static perspective. Indeed, France had absolutism; regional elites could shape the manner in which those at the centre employed their power by both protecting their own interests and resisting merely in their own region against political economic demands from the centre. Obviously, absolutism was reached in France by restricting the access of various actors and groups to the central power and decision-making processes (Perry et al., 2013, p. 238) as happened elsewhere. ${ }^{11}$ It was seen from a dynamic perspective that regional (or peripheral in a broader term) forces could however challenge the centre or even occasionally unitary when they found chance, ${ }^{12}$ where their political access and participation had already been restricted. This in fact reflects the ongoing interplay between the centre and the periphery. For example, in the French revolution, peripheral forces gained a decisive victory, adeptly exploiting 'the incapacitation of the central

\footnotetext{
${ }^{10}$ It is noteworthy that ethnic and cultural fractionalisation is higher in the United States, Canada, Switzerland and Belgium than France and the United Kingdom (Fearon, 2003).

${ }^{11}$ According to (Perry et al., 2013), the General Estate had never executed a check and balance system over the king. Free from controls, the French monarchs succeeded in creating a unified state, but regional loyalties and politics remained powerful for centuries. In contrast, when the English monarchs sought to monopolise their power, barons resisted, re-captured and raised their power in the centre. The English parliament consequently curbed the English monarchy, thus paved the way of liberal democracy.

${ }^{12}$ For example, when Charles V intended to save the French King from captivity, the regions that had militarily vulnerability gave consent to cover the cost of setting up an army, but the regions that were militarily secure did not admit it. Later, Charles VII was threatened by attacks from England and the Duke of Burgundy, all the regions accepted to cover the cost of a war since all felt threatened and insecure (Bates, 2017, pp. 35-36). The accord of Troyes had provided for a legal base for the English king to sit in the throne of France through the alliance with Burgundy, which clearly undermined France's unitary. Charles VII eventually managed to break the alliance, conferring concessions on Burgundy's elites (Warner, 1997). As a result of such challenges from regional powerful elites to the kings, unitary in taxation had not been reached until reforms of the French Revolution (Rosenthal, 1998, p. 70), the mass uprising that involved urban wage earners, petty traders and peasants as peripheral political forces.
} 
[absolutist] state' apparatus of the Old Regime (Skocpol, 1988, p. 41), but then the following breakdowns of the centre in later decades brought other absolutist regimes (Goldstone, 1991, p. 479).

As such, peripheral forces can be based on class, ethnicity, race, religion, different forms of culture, etc. If the excessive central power succeeds in banning or restricting the political participation of others outside the centre or the dominant coalition through coercion or threat of violence, peripheral groups (and their leading actors) may despondently revert to strong regionalism, employing discourse based on different forms of culture or other differences.

Repeated challenges against the central power, often witnessed in the history, suggest a dynamic confronting relationship between the central power and peripheral movements, between "nation builders" or unitarists and "localists" or regionalists, and "between owners and non-owners of the means of production" (Mardin, 1973). "Each time a compromise -or even a one-sided victory- was obtained" from this confronting relationship, "some integration of the peripheral force into the center was achieved" in the West over time, "obtaining some recognition of their autonomous status" (Mardin, 1973). According to Acemoglu and Robinson (2005, p. 4), "the threat of social disorder was the driving force behind the creation of democracy in Britain". Indeed, peripheral forces and elites with relatively weak positions in the dominant coalition valiantly struggled with the English monarch, and in turn liberal democratic institutions were gradually formed as the cumulative outcome of this struggle and of each reconciliation achieved. ${ }^{13}$

Democratic values and norms did not appear out of the blue in England. In his book, The First Transition from Primitive Socialism to Capitalism: England, Kivilcimli (1965b, pp. 1317) shows that technical and geographical productive forces are not underlying factors in explaining the emergence of capitalism in England. Formal and informal institutions such as traditions and customs, coined as "history productive forces", and collective action, coined as "human productive forces" (Kivilcimli, 1965a, pp. 17-18) essentially initiated economic and political development in a stage of history where the expansion of global trade offered favourable circumstances (Kivilcimli, 1965b, p. 18). ${ }^{14}$ Likewise, in Understanding the

\footnotetext{
${ }^{13}$ For example, unlike the French Parliament, the House of Commons, governed by the social capital of English people, did not let the monarch act arbitrarily, as seen in the struggle between Charles I and the Commons and in the Glorious Revolution of 1688 that limited the King's power indelibly in favour of the Parliament.

${ }^{14}$ According to Kivilcimli (1965b, pp. 81-82, 42-43), ancient civilisations, which lasted for thousand of years, ruined the character of the people under their sovereignty and in degeneration caused by usury-merchants. Being at the beck and call of the most debased person in power became a principle over centuries. However, norms
} 
Process of Economic Change, North maintains that 'choices in the present are constrained by the heritage of institutions' (p.51), which 'structure human interaction by providing an incentive structure to guide human behavior' (p.66). Now that development is pathdependence, we need to highlight that RCT scholars generally examine the pathdependencies of Western developed countries and colonial countries but not less developed countries with imperial backgrounds. In the next sections, we shall have the same discussion for Turkey as a less developed country that inherited institutional heritage from the Ottoman Empire.

\subsubsection{The Case of Less Developed Countries in Africa as Former Colonies}

In the Development Dilemma, Bates (2017, pp. 52-61) argues that former colonial countries share similar political-economic characteristics associated with early modern France, such as "high levels of cultural diversity", "ethnic polarisation" and, "regional inequality". To him, the colonial powers created cultural, political and economic diversities in developing countries, as they brought forth territories that covered culturally diverse populations to decrease their costs of governance (Bates, 2017, pp. 52-53). Moreover, "the European occupiers helped perpetuate subnational polities and empower local elites at the local level" as well as "vested local elites with control over land", thereby ensuring the security of their order (Bates, 2017, pp. 54-56). From an economic aspect, the colonial powers invested in certain geo-economical areas that bestowed abundant natural resources and profitable agricultural products (Bates, 2017, p. 56). Divided across political, economic and ethnic fault lines, the former colonial countries had the political terrains that resemble what we described for early modern France.

Probing post-colonial Zambia and Kenya for his analysis, Bates does good service by showing that diverse regional contexts brought regionalism and shaped the political terrain in which Zambian and Kenyan politicians exerted their power (Bates, 2017, pp. 62-86). Having to expand their political bases in such a political terrain to consolidate their power or survive politically, the political elites who were threatened by oppositions opted for establishing authoritarian regimes, and employed their power in a manner that harmed the development of their nations, as did the French monarchs before (Bates, 2017, pp. 87-113). Who were

and values of the English people that originated from barbarism could be preserved from the rule of ancient civilisations. So loyal were barons to their kin members that they melted their interests with the interests of the people and did not let the English monarch arbitrarily. The monarch in France, however, allied with the aristocracy and the ecclesiastical- the institution of usury-merchants of the Roman Empire -, by providing them with exemptions and privileges, in return of acquiring a status of a dictator authorised by the God, as did its their Eastern counterparts. 
politically those oppositions? As Bates (2017, p. 105) underlines that '[i]n the language that was fashionable at the time, they stated that while Kenya's economy may be prospering under Kenyatta, the "center" was diverging from the "periphery" and prosperity was unevenly distributed'. The centre was represented affluent regions, of which economy the rural bourgeoisie controlled, whereas the periphery was poor regions even lacking of sanitary conditions.

With the end of the Cold War, the Western countries pressured the African governments for democratic openings such as competitive elections. We know that the central states of many African countries collapsed or greatly weakened in this period when faced with peripheral violent actions, though regionalism drove them to establish a highly centralised state.

Apart from this, many countries that transitioned from an empire to a modern state have not experienced any collapse since the Cold War, except for those which were collapsed by external interventions. These countries clearly comprise a sample that their common points have not been revealed sufficiently. At least, we can display how Turkey differs from former colonies, so can critically assess Bates's argument.

\subsection{The Case of Turkey: State Formation and Development from the Aspect of the Conflicting Relationship between the Centre and the Periphery}

In this section, our main purpose is to show that Turkey's failure in achieving political economic development is rooted in the institutional heritage from the Ottoman Empire. Particularly, we will focus on the military bureaucratic class and its extractive policies in the Ottoman era. Then, we will show that this class has continued to dominate the political centre in modern Turkey, allying with large-scale capitalist classes. Indeed, their use of power has shaped the political and economic terrains of the country and led to intense political struggle between the centre and peripheral groups. To maintain their position in those struggles, the military-bureaucratic class allied with various social groups and classes or factions within classes, all with their own vested interests. The formation of a highly centralised state has been the apparatus of this class to have a constant grip over the country. This class has succeeded in creating a homogenous population through nation-building, so greatly prevented regionalism. However, their efforts to thwart the political participation of those who are disturbed by political-economic policies have induced the formation of peripheral groups.

It is difficult to talk about any political, economic and cultural diversities in Turkey that were artificially created by any colonial power. As the Ottoman Empire was gradually 
disintegrating because of internal conflicts induced by growing nationalist movements, the Muslim population who had lived in the Balkans, Caucasia and the Middle East immigrated to what is contemporary Turkey. The fact that non-Muslim groups, such as Greeks and Armenians, were forced to leave Anatolia as a result of nation-building policies (Yeğen, 2006) resulted in a relatively more homogenous population to establish itself in Anatolia. In modern Turkey, cultural, political and economic differentiated groups - bar the Kurds - have significantly remained dispersed across the territory. True, Turkey has far less ethnic and cultural diversity than almost all of the Sub-Saharan African countries (Fearon, 2003). In fear of facing a political conflict similar to what the Ottomans faced in the Balkans and the Middle East, the state officials have pushed the population to assimilate into the identity the state approves. In this sense, regionalism are always considered by the state officials a harmful thing against the sublime interest of the state in the era of nationalism: devletin bekasinı korumak - to ensure the survival of the state - in its well-known Turkish formulation. The implementation of displacement and compulsory settlement of the Kurdish population (Yegen, 2009) and the authoritative nationalisation of education and culture (Aksan, 2006) are just a few examples of the policies applied to avoid regionalism and ensure the integrity of the state with its territory.

Some institutional arrangements within the state formation also help to curb regionalism. At the local level, provinces and towns are managed by two groups of administrators. Valis in provinces and kaymakams in towns are assigned and controlled by the central government. Although mayors with limited mandates are democratically chosen by the people, they are highly controlled by the central and local bureaucracy. ${ }^{15}$

Another factor that curbs regionalism is the law of diminishing returns. Many families who live on agriculture started to migrate to and group together in big cities and industrial coastal cities to start a new life in the 1950s (Robinson, 1952, 1958). This process has allowed individuals from different backgrounds to compose of nearly half of the population in those

\footnotetext{
${ }^{15}$ Despite the conditions of EU membership, the Turkish state objects to the adoption of the European Charter of Local Self-Government ${ }^{15}$, which gives a (high) degree of authorisation and financial powers to local authorities (Akçadağ Alagöz, 2011, 24 Haziran).
} 
cities today. ${ }^{16}$ The influx of the people to urban areas has prevented regionalism, except for part of Eastern Anatolia in which the Kurds are densely populated. ${ }^{17}$

From all these facts, we argue that there has been no regionalism as strong as that in France or former colonies, shaping the political economic terrain of the Ottomans and Turkey. In the next two sections, we will delineate the fact that the bureaucratic class has not allowed regionalism but created strong peripheral movements by blocking the political participation of the people outside the dominant coalition, so limiting the establishment of liberal democratic institutions. Furthermore, the institutional heritage inherited from the Ottomans shaped political economic development pathway of modern Turkey.

\subsubsection{Turkey's Path Dependency: The Political Economic Heritage from the Ottomans}

The Ottoman Empire was at least as strong as England and France in the Late Middle Ages, but could not accomplish the great transformation successfully because of its institutional characteristics. The Empire had managed to survive for over 600 years since its foundations, and collapsed at the end of the First World War as other land empires such as the AustroHungarian Empire and the Russian Empire. After its collapse, the institutional characteristics of the Ottoman Empire passed to Turkey and played a key role in establishing modern Turkey's political economy. The most important is the excessive dominance of the militarybureaucratic class as the central political power. As Sugar (1977/1993, p. 273 cited in Kumar, 2017, p. 96) argues that ' $[u]$ nlike the European nobility, the Ottoman ruling class enjoyed no hereditary rights. It was a purely functional class, defined not by ethnicity, language, or religion, but by its role in the running of the state'. The definite outcome of such a ruling class formation was an excessively central state apparatus that undermined the development of economy and of democratic institutions.

Anatolia and Europe showed considerable similarities in the Late Middle Ages. The House of Osman, known as the Ottomans, emerged from a political setting related to feudalism characterised by "the atomisation of politics and economy", which had gradually formed in Anatolia of the Seljuk Interregnum, and in the unrestful Balkans of the Byzantium Empire (Kilicbay, 2000, p. 24). It subdued other houses, and took the qualities of a central state in the

\footnotetext{
${ }^{16}$ The total population of the three most populated cities in Turkey, Istanbul, Ankara and Izmir, is equal to nearly 30 per cent of the total country population. With some industrial cities that attract migration, this proportion increases to nearly 50 per cent of the total population (Turkish Statistical Institute, $2017 \mathrm{~g}$ ).

${ }^{17}$ The conglomeration of the population in urban areas has brought individual strategies relying on communitylevel solidarity. Seeking and forging relations with fellow-townsmen or fellow-villagers in urban areas has been such a strategy to survive or increase social and material welfare (Aktas, Aka, \& Demir, 2008). Again, the rise of Islamic organisations based on religious communities is the result of migration to urban areas.
} 
mid- $15^{\text {th }}$ century after capturing Istanbul from Byzantium (Kilicbay, 2000, p. 26; Kivilcimli, $2010 \mathrm{a}, \mathrm{pp} .63,66)$. Though they politically and economically peaked in the mid-16 ${ }^{\text {th }}$ century when having expanded its territories to Europe, Asia and North Africa and controlling a great part of traditional global trade routes, as Kivilcimli (2010a, p. 33) argues, the Ottoman Empire, which shared considerable political economic similarities with France, could not bring itself to modernisation.

After Mehmet the Conqueror captured Istanbul, he reformed the state by inheriting institutional qualities from the Byzantium Empire, including setting up a strong political core that was supported with a standing army, and took a superior status to any individual and the entire society similar to the French counterpart (Kivilcimli, 2010a, pp. 66-70, 78). Until his period, all ghazis had owned the right to speak and to be heard, but they lost such a right with the establishment of the excessively central state (Kivilcimli, 2010a, pp. 79-83). While the English acting collectively were threatening the English monarch with rebellion and gradually creating liberal democratic institutions to limit his power, the central power with a strong salaried standing army ${ }^{18}$ easily precluded any collective action or threat of the common people ${ }^{19}$.

The Ottomans applied various policies to set up and maintain the central power but created disincentives through extractive institutions to economic development this way (Acemoglu \& Robinson, 2012, p. 120). For example, a class of "slave administrators" was formed to rule the Empire, who were conscripted in their childhood and brought up as Muslims, with a view to limiting the military and political power of local Muslim elites (Mardin, 1969; Şevket Pamuk, 2007, pp. 22-23). To this end, the management of lands (timars), of which revenues were used for military services, was given to the military officials of this class (timariots) instead of to local Muslim elites (Şevket Pamuk, 2007, p. 23), and timariots were replaced at certain intervals to avoid any formation of local powers (Quartet, 2004, p. 61).

The definition of property rights was not clear that small producers only had usufructuary rights on the lands with public property rights, which were controlled and managed by

\footnotetext{
18 The Janissary corps under the direct command of the sultan was the first standing army in Europe (Ágoston, 1999 , p. 122). This shows well the extent of centralisation in the Ottoman Empire. As the sultan was such powerful, it was not likely to limit his power.

19 The subjects of the sultan are called as reaya in the Ottomans, which etymologically means animal, sheep or cattle that is herded or shepherded (Reaya, n.d.). This explains well the position of the common people in the mindset of the Ottoman elites.
} 
timariots (Kivilcimli, 2010b, p. 137; 2010c, p. 69). ${ }^{20}$ Inherently, small-scale producers and timariots strived for holding lands as private property and bequeathing them to their own next generations (Kivilcimli, 2010c, pp. 72-74). Whilst the former was squeezed greatly in this struggle, the latter strengthened their economic bases with the expansion of the lands under their control (SSevket Pamuk, 2007, pp. 23-24) under the unclearly defined property regime.

When the Ottoman sultan was forced by economic imperatives after the $17^{\text {th }}$ century, he rented public lands to local families together with the right to collect tax (Genc, 2014, p. 96; Kivilcimli, 2010c, pp. 138-142) similar to what the French monarchs did. The main purpose was to create incentives for the military bureaucratic officials to boost agricultural production. The local officials and tax collectors (multezims) as their subcontractors endeavoured to transfer the lands to their ownership exploiting this policy, abused the power for taxation to unfairly appropriate agricultural surplus generated by the peasantry, and eventually compelled the central administration to gradually accept their right to hold lands as private property through the Ottoman Land Code of 1858 (Önal, 2012).

According to Kivilcimli (2010c, p. 205), the unclearly defined property regime ${ }^{21}$ long prevented the local officials and multezims to become capitalists in a way that took place in England; rather, they became "a coterie of revenue earners', enjoying extractive policies of the state. Multezims, accumulating wealth by exploiting the peasantry, turned into ayans in later centuries and then somewhat politically challenged the state, but desperate small producers flowed into cities as a result of this exploitative process (Kivilcimli, 2010c, p. 219). Obviously, capitalist farmers could not emerge in the setting where there were no private land rights (Kivilcimli, 2010c, pp. 153-155).

\footnotetext{
${ }^{20}$ Kivilcimli $(2010$ b, pp. 39,102$)$ objects to those who define the prevailing property type of lands in the Ottoman order as state property, and he argues that it, instead, was public because "Miri" (public property) lands are supposed to be allocated to the people with usufructuary rights for some purposes, such as earning livelihood, covering expenses of training soldiers, and paying taxes to the state. Whenever the Ottomans conquered any place, they terminated private property of lands to turn them into "Miri" lands, which were not accepted property of any individual but the public. As Kivilcimli (2010b, p. 115) puts, in the early period of the Ottomans, the sultan could event not seize both property rights on Miri lands and the benefits derived from them to augment his own wealth.

${ }^{21}$ The risk of losing land at the end of a renting term due to public land rights created disincentives for those large landholders. In fact, they lived in Istanbul and subcontracted multezims to collect taxes, thus assuming the characteristics of a "rentier" class (Genc, 2014, p. 107). Multezims unscrupulously squeezed small producers through taxation and usury to raise their revenue but so creating disincentives to increase productivity (Kivilcimli, 2010c, pp. 142, 197). Usury-merchant capital owners lent money in return of interest income to multezims or bureaucrats. Overall, small producers on land with public property rights served for the interests of officials, multezims and usury-merchants in the dominant coalition (Kivilcimli, 2010c, p. 166).
} 
As a result, certain limitations to the power held by the sultan, (not dissimilar to the Magna Carta), were just introduced in the first decade of the $19^{\text {th }}$ century as a result of an agreement signed between strengthened local rulers (ayans) and the sultan (Kiziltan, 2006). And contrary to the regional actors in France, who could curb policies imposed by the monarch through regional assemblies and bureaucracies, local actors had almost no such institutions to do so in the Ottoman Empire. All show that regionalism was remained politically weak in Anatolia.

The sultan gave high importance to controlling not only rural but also urban areas, especially in the capital city, to pre-empt a political disturbance that would threaten his power (Quartet, 2004, p. 80). A "provisionist policy" was followed to satisfy domestic demand for food. Import of food was thus encouraged through taxation, but its export was discouraged despite the existing control over global trade routes (Genc, 2014, pp. 41-44). The merchant capital owners could not play an important role in cementing ties between the rural and urban industry (Kivilcimli, 2010c, pp. 153-155) as their counterparts did in Western Europe (Şevket Pamuk, 2007, p. 57). More importantly, 'it was highly difficult to make investment [in the urban sector] by diffusing into the strict and cohesive structure of communitarian and egalitarian guilds, which obtained strong support from the state', as Genc $(2014$, p. 87) states, 'profit restrictions had their appeal lost' this way. In such a setting, the usury-merchants, who had strong ties with high-level bureaucrats, were granted privileges for importing food and transporting them from towns to cities for urban and military consumption (Kivilcimli, 2010c, p. 225). They also purchased food from domestic producers at lower prices through their monopolistic power and sold them to the army at higher prices (Kivilcimli, 2010c, p. 227). This again inevitably undermined incentives for rural producers to increase agricultural production and made the great transformation impossible.

What we have emphasised in this section is important to understand what made modern Turkey. The sultan was the paramount representative of interests of the military-bureaucratic class and set up a more centralised, absolutist state than its counterpart in Europe. He strictly controlled both politics and economy from the centre and did not allow the rise of any threatening local power to his political position. The military bureaucracy officials, multezims, usury-merchants were all in the dominant coalition but politically inferior to the sultan, who could easily confiscate their wealth if they politically objected to him. During the political stagnation period the sultan, however, was able to be forcibly replaced by the military bureaucracy class with another member of the Ottoman dynasty, as seen in the case 
of Selim III (Inalcik, 2013, pp. 53-54). This shows that the sultan was not superior to interests of the class itself. In study of North et al. (2009), there is no argument about the class-based character of the military.

In such a political-economic setting, open access institutions could not be established. Where the property rights were not clearly defined, this dominant coalition seized the agricultural surplus generated by the peasantry in the periphery, prevented capitalist relationships that would induce the great transformation and shared the systemic rents created to among those in the dominant coalition.

\subsubsection{Modern Turkey until 1980}

In this section, we emphasize two main points about the period until 1980. The militarybureaucratic class sought to keep their political position at the centre, allying with different classes and groups, and adjusted their policies to changes in international power structures. In doing so, they were challenged by different groups and classes from the periphery such as Kurds, Alevis ${ }^{22}$, and students and urban workers adhere to Marxism. As Turkey was gradually undergoing the great transformation, large-scale capitalist classes over time predominated large landholders and small and medium-scale capitalists in the dominant coalition. The policies defined by the military-bureaucratic class, and civil governments that represented various economic and socio-cultural groups, intensified peripheral movements and occasioned frictions in capitalist classes throughout the period.

After the Ottomans admitted defeat at the end of the First World War, Mustafa Kemal Pasha, representing interests of the Ottoman military and bureaucratic classes (Karaosmanoglu, 2000), managed to align national interests with economic interests of local Muslim notables, including large landholders and Muslim merchants ${ }^{23}$ (Başkaya, 1991, pp. 43-50), in order to wage a (successful) war of liberation against victorious European states. The new modern state, founded in 1923, was based on three main principles: secularism; Turkishness referring to adherence to the Turkish nation-state -; republicanism that may be deemed as

\footnotetext{
22 The Alevis are the members of a heterodox sect of Islam.

${ }^{23}$ The capitalist land relations during the Ottoman reign became possible through the introduction of the 1858 Land Code, legalising private property rights on lands. Rapid urbanisation and industrialisation in European countries increased demand for agricultural raw materials and goods produced in the Ottoman Empire in the 19th century, and linked large landholders with European markets (Kasaba, 1993, p. 76). In particular, large landholders (multezims) in the West Anatolia region therefore assumed the character of merchant-agricultural producers, selling agricultural crops to Europe and imported goods to domestic people, as well as continued to derive profits through usury (Önal, 2012). As for Muslim merchants, they replaced non-Muslim ones through coercion and economic policies applied by the military bureaucratic class (Başkaya, 1991, pp. 37-39; Keyder, 1979).
} 
centralisation (Ergil, 2000), and the new state followed the path of capitalist development with some level of Westernisation (Başkaya, 1991, pp. 33-36).

These principles immediately sparked political reactions from the periphery, i.e. Kurdish tribal elites and conservative anti-modernist Muslim elites. The military, in turn, responded with coercion (Narli, 1997; Orhan, 2012) and succeeded in firmly securing their power at the centre. Afterwards, they adroitly intervened in politics through military coups and the constitutional institutions that were established in interim regimes (Cizre-Sakallioglu, 1997; Karaosmanoglu, 2000). As Jung (2008, p. 130) articulates clearly, '[t]he particular character of Turkey's civilian-military relationship was that the armed forces were not accountable to civilian rule, but that the civilian state institutions were accountable to the generals.'

The political centre generally shaped the use of power and development ways of the country under the restrictions imposed by the international power structure. During the inter-war period, liberal democracy was not popular in the world (Hayek, 2005, pp. 42-44); foreign capital flow to Turkey was seriously limited due to the adverse impact of the Great Depression (Owen \& Pamuk, 2002, p. 29). Civil representatives of the military-bureaucratic class adopted a single party system along with the Republican People's Party (CHP in Turkish acronym) and economic statism to get the national economy integrated and industrialised through public investments (Owen \& Pamuk, 2002, pp. 30-33). Facilitating private capital accumulation in every manner, the state invested in economic areas, in which private enterprises averted to invest (Aydin, 2005). Smallholders were squeezed through the low-priced crop policy whereas large landholders were supported with subsidies (Başkaya, 1991, pp. 147-148). Large landholders still had a far more powerful political position than the newly emerging industrial bourgeoisie at the end of this period (Aydin, 2005, p. 27), and the merchants strengthened their position greatly through international trade and speculations, and profiteering in domestic markets during the Second World War (Başkaya, 1991, p. 152).

The international system was based on a bipolar power structure after World War II. Whilst the use of force abroad remained limited in this period, superpowers used financial assistance to keep any country close to their sides (Bates, 2001, p. 75). The result of this international political environment was the foundation or maintenance of (excessively central) nondemocratic states in most of the developing world (Bates, 2001, p. 82; Huntington, 1984), ${ }^{24}$

\footnotetext{
${ }^{24}$ We can make this inference from words stated by Bates (2001) that "[d]uring the Cold War, the United States was often criticized supporting regimes in power that violated its democratic principles. As illustrated by the case of Mobutu [of Congo], the government did indeed often ally itself with dictators and authoritarians."
} 
using coercion arbitrarily to halt opponents (any peripheral movement against the centre) (Bates, 2017, pp. 106, 108-109).

When the Cold War started, the Turkish state, however, found sufficient incentives to set up part of liberal political institutions. In fear of being invaded by the Soviet Union, the CHP opted for allying with the West, thus countenanced a transition to a multi-party political system as a basic step for democratisation (Karaosmanoglu, 2000). They eventually lost their power in 1950 to the Democrat Party (DP) and handed power over. According to Aydin (2005, p. 27), "[t]he different class interests represented within the state were a significant factor, among others, in the abandonment of a single party system in favour of a pluralistic democratic system in 1950."

That the DP came to power was a silent but strong reaction of a wide group of the people in the periphery, such as Islamic groups and Kurdish tribes, and landholders in the dominant coalition, which had been squeezed to finance the army during World War II (Mardin, 1973; Owen \& Pamuk, 2002, pp. 141-142). The DP government integrated Turkey in the world economy and Western organisations ${ }^{25}$ and obtained economic and military support in return (Aydin, 2005, p. 28). They satisfied smallholders and large landholders by introducing policies to give subsidies and higher prices for crops and diffusing intensification methods for increasing agricultural productivity (Aydemir, 2000, pp. 207-208, 218-219; Başkaya, 1991, pp. 172-173). Liberal trade policies of the DP also helped the merchants grow their wealth. However, dissatisfaction started to grew after the mid-1950s, because of increasing inflation, recession and financial incapability of importing inputs for agriculture and the industry, especially among smallholders, the working class, the manufacturing bourgeoisie, the bureaucracy, and a group of intellectuals who criticised the government due to their reactionary, anti-democratic political practices (Yerasimos, 1992, pp. 230-232). Their discontentment and protests were not enough to remove the DP government from power, and ultimately, the Turkish army staged a military coup in 1960 to restore its power and order (Yerasimos, 1992, pp. 232-233). This initiative nevertheless widened the distrust of conservative grassroots towards the CHP (Mardin, 1973), which was brought to power by the Army and governed Turkey until the Justice Party took over in 1965 with the support of the constituency of the DP.

\footnotetext{
${ }^{25}$ Such as the North Atlantic Treaty Organisation, the International Finance Organisation, and the International Development Association.
} 
Through the 1960 coup d'état, as Daldal (2004) contends, a new middle class composed of the military-bureaucratic class, a group of intellectuals and the manufacturing bourgeoisie took action and formulated development policies concerning import substitution industrialisation. Where economic planning "relegate[d] all control over one's fate to the limbo of bureaucratic decision" (Mardin, 1973), the large-scale trade and industrial bourgeoisie, which mainly agglomerated in western Turkey and coastal areas, particularly in Istanbul, greatly developed in the 1960s through rents created under protectionist policies (Ataay, 2001; Başkaya, 1991, p. 182; Keyder, 1979) as well as through partnerships with the Western merchant and industrial capitalists (Daldal, 2004). Military and economic aid from Western countries continued in this period, and thus Turkey largely acted in accordance with western international policies (Sander, 1979).

The military-bureaucratic class, the development bureaucracy and the large-scale capitalist classes formed the dominant coalition at the centre. As the capitalisation of agriculture was being accelerated in this period, villagers who were migrating to urban areas inherently swelled working class numbers (Yerasimos, 1992, p. 247). This period also marked a widening of the developmental disparity between western and eastern Anatolia (Yerasimos, 1992, pp. 382-383), fuelling sentiments of Kurdish regionalism. The left-wing young people, the working class and Kurds started to actively oppose the dominant coalition as a wing of the peripheral movement after the-mid 1960s.

The distribution of privileges to the large-scale urban bourgeoisie and the agglomeration of capital in west Turkey continued to provoke reactions from different interest groups and in relatively less developed regions in the 1970s. Holding conservative Turkish-Islamic views (Keyder, 1979), the petty capitalists ${ }^{26}$, who had burgeoned in urban areas all across Turkey, passively defied the superiority of the large-scale bourgeoisie (Ataay, 2001; Keyder, 1979) without initiating actual conflict. They continued to mobilise under various centre-right, farright and Islamic right-wing parties, which would govern Turkey through a coalition government during a large part of the 1970s.

In the 1970s, the political centre got stuck in political and economic problems. As a global crisis of capitalism hit Turkey's economy severely, the military bureaucratic class followed a

\footnotetext{
${ }^{26}$ The small and medium-size capitalists had an intermediary position between the large-scale trade bourgeoisie and the industry bourgeoisie, and between local raw materials and commodity markets (Ataay, 2001). This group acquired rapid capital accumulation by exploiting the non-qualified labour force, thus strongly objecting to wage rises, supporting the immediate transformation of rural areas in a way that would create a labour surplus in agriculture (Keyder, 1979).
} 
strategy to halt the pressure coming from the periphery: they crushed leftists and Kurds with the help of right-wing fascists and Islamists (Keyder, 1987, pp. 217-222). When they restored their power during the 1980 military coup, they initiated "Islamisation", in line with "religionisation" or new conservatism, as seen in many cases in the capitalist world, to facilitate the implementation of neoliberal economic policies (Kucuk, 2010, pp. 59-74; Yasli, 2014, pp. 22-23, 64-68). Apparently, international dealings, and efforts to find a proper position in international power structures impelled the military bureaucracy did so (Fuller, 31 October 2004). ${ }^{27}$

After all, the political Islam disintegrated not only the working class by dividing the urban poor via religious identities (Kucukaydin, 2012, pp. 49-52) but also the Kurdish political movement in the same way. This political strategy would render the position of the militarybureaucratic class gradually vulnerable to Islamists after 1980 and paved the way for the conservative Islamist JDP.

\subsubsection{Modern Turkey between 1980 and 2000}

Turkey and many other less developed countries carried out the same strategy for development during the 1960s, 70s and 80s, - import substitution industrialisation - but ended this due to the late-century shocks to the global system, which led to dramatic changes in development policies and security conditions of developing countries.

Following the end of the Cold War autocratic regimes were faced with not only democratic demands from both inside and outside (Bates, 2001, pp. 93-97) but also economic pressures where public budget deficits had mounted because of surges in petroleum prices and exorbitant costs of protectionist policies and patronage (Bates, 2001, p. 90). The policies recommended by a wide group of people, including creditors, businessmen and intellectuals were to lower public budget deficits, lift international trade barriers and avoid protectionism (Bates, 2001, pp. 90-94). In Prosperity and Violence Bates describes this:

Changes in the international economy placed new fiscal limits on developing regimes; no longer presiding over fountains of privileges, their political leaders found it more difficult to seduce local warlords, enticing them to disband armed retainers and to affiliate with the center [emphasis added]. The end of the century was therefore marked

\footnotetext{
${ }^{27}$ Graham Fuller (31 October 2004), a former operations officer having served for the Central Intelligence Agency in Turkey, expresses the international relations between the United States and Turkey required to use Islamisation to halt the leftist movement. They formed the Green Belt of Islam to stop the Soviet Union. Acting contradictorily with their ideology, they supported anti democracy in Turkey to eliminate the possible threat of communism.
} 
not only by the spread of democracy in the developing world but also by the spread of violence (p.97).

Late-century shocks changed the set of incentives that had helped the sustenance of excessively centralised states, and paved the way for peripheral movements and violent collapses of some countries in Africa and Balkans. But Turkey did not experience any serious political pressure from the West involving democratic demands ${ }^{28}$, and violence remained regional.

Turkey had already experienced some of economic problems attributed to the 1990s in the 1970s, such as foreign trade deficits, public budget deficits, swelling debts and increasing inflation rates (Buğra, 2008, p. 197). However, she did not face any state collapse similar to some African countries, and continued to receive political, military and financial support from the West because of its highly important geopolitical position in the Middle East. How did Turkey differ from African countries?

According to North et al. (2009, p. 73), some natural states are fragile as their dominant coalitions depend on individual interactions and trust between powerful elites, and therefore they cannot create sophisticated and durable institutions in the private and public domain. Naturally, the distributional mechanism of rents among elites was foiled by late-century shocks, resulting in the collapse of some African countries.

When it comes to Turkey, the state formation was being secured by the long-existing military bureaucratic class ${ }^{29}$. Despite all vagueness in his categories ${ }^{30}$, we can say that Turkey has been a mature natural state except for last few years. According to North et al. (2009, p. 73),

[i]n mature natural states, credible institutions evolve that provide organizations a measure of rule of law. As more complex organizations develop, both inside and outside of the formal government, the distinction between public and private organizations begins to appear. The first steps toward Weberian states or governments with consolidated, monopoly control over the military occur in mature natural states. Sustaining some amount of rule of law for elite

\footnotetext{
${ }^{28}$ For example, the European Union had not demanded democratic changes in Turkey's constitution until they accepted its candidateship to the Union in December 1999.

${ }^{29}$ Its members are not powerful individuals. They are bound to the legal framework to be replaced or removed except for the case of a crise threatening them, and whey they retire from the military service, they become ordinary people. So, the class itself is powerful.

${ }^{30}$ North et al. (2009, pp. 55-76) classify limited access orders or natural states in three categories: fragile nature state, basic natural state and mature natural state. Although there are important differences between these categories, they use only "natural states" in their book to make arguments and explanations, which causes confusion and unclearness.
} 
organizations appears to be incredibly complicated to pull off and is the beginning of the doorstep conditions.

Relying on "the asymmetric power structures that the Turkish Republic inherited from Ottoman times" (Jung, 2008), the military-bureaucratic class has created a distinction between the government and the state. Its members have kept the survival of the state as a sublime interest and tightly controlled it so that they can materialise their interests and secure the creation of systemic rents in the dominant coalition. As North et al. (2009) do not delve into mature natural states taking into account of non-western countries with an imperial background, they do recognise that the (military) bureaucratic class in those countries is a major barrier to transition to open-access orders, with its monopoly over violence.

Furthermore, it has always been capable of acting flexibly, continuing to cooperate with the West on economic and political levels, so increased legitimacy. At that time, they willingly espoused neoliberal policies under the supervision of the World Bank (WB) and the International Monetary Fund (IMF) between 1980 and 1984 to integrate the national economy to the world capitalism (Buğra, 2008, pp. 197-200).

They also framed their foreign policies to help the West to deal with the recently founded mullah regime in Iran, threatening Western interests, and removed their veto against the return of Greece to the North Atlantic Treaty Organisation (Ahmad, 1993, pp. 183-184). And when the US-led multinational forces intervened in Iraq in 1991, the state allowed them to use a military base for airstrikes, notwithstanding the substantial loss of revenues that would have derived from export to Iraq and oil pipelines as well as any possible retaliation from Saddam Hussein (Brown, 2007). The geo-strategical position were used by the military to increase bargaining power in international dealings and keep the power at the centre of the dominant coalition.

The Turkish state received a significant degree of support from the West, unlike many developing countries, despite their anti-democratic practices. For example, while it was fighting with the PKK through a counter-insurgency strategy, human rights of ordinary citizens were seriously violated. ${ }^{31}$ Furthermore, it seems that the counter-insurgency strategy was taught by military officials of the US to their Turkish counterparts (Jongerden, 2015, p. 95). And the West sold Turkey arms and equipment for the counter-insurgency (Jongerden, 2015, pp. 90-91).

${ }^{31}$ For details, look at the reports of TGNA Human Rights Inquiry Committee (2013) and Human Rights Watch/Helsinki (1993). 
Though Turkey had been shaken with economic recessions and crises at short intervals between 1988 and 2001, loans and capital inflow from the West revived the economy, thus reinforcing the power of the political centre, and helping to surmount the high costs of military operations to fight the PKK.

The support given by the West was not gratuitous; Turkey was required to implement neoliberal economic policies, which were detrimental to the agricultural sector and impelled sharecroppers and smallholders to migrate to urban areas, undermining the position of labourers in the market (Buğra, 2008, pp. 200-201). Neoliberal economic policies were important to satisfy international economic actors and the large-scale bourgeoisie in the dominant coalition. Capital-friendly public policies, and the measures that were taken in the labour market to repress wages and suppress trade unions played a decisive role in gaining their support (Boratav, 1999, pp. 89-92). To alleviate strong reactions, within three years after the coup in 1980, the military regime disorganized and crushed the working class, leftists and Kurdish activists and showed its political flexibility to transition to civil democracy.

Turgut $\mathrm{Ozal}^{32}$ - elected mainly by conservative and centre-right constituencies - set up the Motherland Party government in 1983. The Populist Party, representing those who were discontent with the military coup and its results, obtained around $30.5 \%$ of the votes. This proved that military-bureaucratic class could render their policies and actions justifiable in the eyes of most people. When Kenan Evren, the leader of the coup, was replaced by Ozal, the military-bureaucratic class retreated from being directly involved in politics. Politicians who had been banned by the military regime returned to politics in 1987 . Weak and mostly short-lived coalition governments were established during the 1990s. Constitutional institutions that had been legalised during the military regime facilitated the militarybureaucratic class to pull the strings of incumbent governments during this period (CizreSakallioglu, 1997).

In the meantime, all the policies deepened urban-rural, secular-Islamist and Turkish-Kurdish divisions in the society in the 1990s (Cizre-Sakallioglu \& Erinç, 2000). The only violent challenge against the political centre came from Kurds, which re-organised themselves into the PKK. The armed conflict escalated in the early 1990s but remained geographically

\footnotetext{
${ }^{32}$ Turgut Ozal was specifically chosen by the military to apply those policies in the post-coup period, who had been employed by the World Bank in 1971-73, and who had a strong relationship with national and international capital groups and organisations (Boratav, 1999, pp. 73-76, 82-86). During his prime-ministership, he gained a chance to introduce himself to the conservative people, promoting his status of saving the country from the economic disturbance.
} 
limited. Meanwhile, the military-bureaucratic class reached the zenith of its political power and further consolidated their popular support by promoting nationalism/patriotism (Karaosmanoglu, 2000).

The societal divisions were also gradually undermining the political base of the military and the western Anatolian large-scale capitalists and frustrated their mutual relationships, but strengthened those of the large-scale and petite capitalists with Islamic or conservative values (Kucukaydin, 2013b, p. 48). Similar to other Muslim-populated countries, Islamic social organisations and networks filled 'the vacuum left by the government' by offering a variety of social services including education, health and childcare (Huntington, 2002, pp. 111-113). By doing so, these organisations extended their political influence over the poor affected by modernisation. Traditional middle-class groups, such as merchants, traders, owners of small businesses, further strengthened the Islamisation process (Huntington, 2002, p. 113).

The rise of political Islam challenged the power of the political centre during the elections in the mid-1990s. But the military-bureaucratic class eventually harnessed their power and removed the coalition government of the Islamist WP and the True Path Party in 1997, alleging that they had violated secular principles of Turkey. Relying on networks with religious communities and their affiliated religious organisations, the Islamic bourgeoisie, which had thrived under neoliberal policies, was also curbed and criminalised by the militarybureaucratic class by means of financial investigations and measures (Hosgör, 2011). All these attempts did not stop the rise of the conservative Islamist bourgeoisie.

The WP, meanwhile, was divided by internal disagreements. The JDP, which was set up under Erdogan's leadership, adopted moderate Islamism more adaptive to neoliberal policies and the Western political tendencies in order to gain the international support. This was a critical strategic move for the conservative periphery. The JDP came to power in late 2002 as a result of the 2001 economic crisis. The Erdogan Administration politically representing the Islamist bourgeoisie succeeded in gaining support of the large-scale bourgeoisie in west Turkey (Yasli, 2014, p. 23) and also managed to get votes from traditional middle-class groups as well as the conservative poor. This change marked the rise of the conservative Islamist bourgeoisie in the dominant coalition, having skilfully leveraged the political reaction of the conservative poor and middle-class groups. 


\subsection{Conclusion}

We have showed that the central power is overwhelmingly dominated by the militarybureaucratic class, traditionally executing high centralisation in Turkey. The secular, westernised bourgeoisie was created by this class and added to the dominant coalition to catch up developed economies with their economic power and investments. The conservative Islamic bourgeoisie and the conservative periphery showed a reaction to these two dominant actors, but the former only sought to strengthen their position in the dominant coalition, as we will see in the next chapters.

This was a stark difference from England, in which the bourgeoisie developed by itself from capitalist relationships in the market and induced the establishment of liberal democratic institutions by rising its power in the dominant coalition. Kucukaydin (2013b, p. 42) explains well the positions of the bourgeoisie and the military class in Turkey's politics:

The bourgeoisie has a real dilemma here. On the one hand, they seek [to have] the actual political power; on the other hand, they do not seek to touch [or disturb] the powerful state apparatus and the army. By keeping that power [close to themselves], they desire to use it as a tool of their own political power. This is because if they did not have such power, they know that they could no longer sustain their own hegemony. Yet, as long as they do not touch their power, there exists no chance to take the political power from their [the military-bureaucracy's] hands. And eventually, they turn into a mere pawn of them.

According to North et al. (2009, p. 153), 'in most natural states access to the means of violence is dispersed throughout the elite. [...] Nothing precludes a faction within a natural state from taking control of military resources.' North et al. (2009, p. 153) add:

Moreover, societies where a single faction dominates the military are unlikely to sustain consolidated control for long, because the factions and groups in the dominant coalition without the means to protect themselves have no reason to believe that the commitments made to them will be honored.

The logic of natural states explained by North does not match with the reality of Turkey. The elites in the dominant coalition have no military power to change the composition of the dominant coalition, and the military bureaucratic class itself possesses consolidated military power. ${ }^{33}$ There is however a symbiotic relationship between economic elites and the military,

\footnotetext{
33 One can question whether understanding the military-bureaucratic class as a single unit is correct. This class surely had political fractions in the course of history. But we can observe at least that they have kept their
} 
and therefore the coalition has existed for long. More importantly, the bourgeoisie is afraid of losing the state apparatus to the periphery, namely the working class and the poor, so giving consent to the military to have a dominant position in Turkey's politics. The military bureaucratic class is in fact an old-fashioned class, coming from the Ottoman Empire. It keeps power by ensuring a political-economic order that provides privileges to the bourgeoisie and by adapting to international power structure.

This structure of the dominant coalition has definitely not conferred peace and prosperity on the people. Particularly, it influenced the development of the country geographically in favour of the western Turkey, thus created a reaction in other regions. However, this reaction did not take place in the form of regionalism but country-wide peripheral movements formed by ideology intertwined with cultural and economic differences. As long as the dominant coalition has blocked their participation, peripheral movements have grown.

Given these facts, the question of how natural state countries similar to Turkey can pass to the door-step conditions to set up democracy remains unanswered in Violence and Social Orders. In the next chapters, we will address that the JDP government, mainly representing the interests of conservative bourgeoisie, challenged with the military bureaucracy, attempted to get rid of a wing of it but did not institutionalise checks and balances over it to cut their direct or indirect interventions in civil politics.

political flexibility without falling apart over violent disagreements and mostly managed to accommodate changing relations and positions among different classes and social groups to hold their power at the centre (Kucukaydin, 2013a, pp. 49-50). 


\section{Chapter 3: The Kurdish Question as a Peripheral Movement: Political Collective Action and Ethnic Social Capital}

\subsection{Introduction}

The Kurdish Question, starting from the foundation of modern Turkey, transformed Kurds into a peripheral movement. The Kurdish political movement first cut across tribes, and later modernisation shaped and changed the movement. We will use the concept of social capital and collective action to understand the Kurdish Question from a critical perspective, so contribute to RCT.

This chapter seeks to understand the Kurdish Question with regard to social capital, or more specifically, to ethnic social capital. This understanding will help us to appreciate the policies of the Turkish state in its dealings with the Kurdish Question, ranging from military interventions to the implementation of development policies. The importance of the question stems from its adverse effect on Turkey's political economic development. The resolution of the problem lies in democratisation and development together. However, the state is not able to approach the Kurdish Question accepting this reality because of the structure of the power in the dominant coalition. The democratisation requires democratic civil control over the military bureaucracy, so leaving the position at the centre. Neither the bourgeoisie nor the military bureaucratic class can desire such a thing. As a result, the Kurdish Question is interpreted in two ways: the military narrative and the development narrative. We will examine why the policies based on these narratives have not yielded the expected results for the state. In this sense, the social capital of and collective action among Kurds will be under scrutiny.

\subsection{Social Capital and Collective Action}

The concept of social capital has been theorized in the social sciences for nearly four decades. As Lan (2008, p. 50) points out, "since the notion of social capital has generated multiple definitions, conceptualizations, and empirical measurements, the continued diversity in such usages without integration may undermine and ultimately bring its downfall as a rigorous scientific concept and theory of social analysis." To avoid confusion, we will be based on the concept of social capital introduced by Elinor Ostrom and her colleagues who attempt to formulate a theory of social capital based on second-generation theories of collective action ${ }^{34}$.

\footnotetext{
${ }^{34}$ The first-generation collective action theories did good service in challenging that people act voluntarily for the attainment of common interests as we see in Olson's analysis of collective action that refers to universal selfishness of the human being in collective action problems. The second-generation collective action theories
} 
In the Logic of Collective Action, Olson argued, "[...] unless the number of individuals in a group is quite small, or unless there is coercion or other some special device to make individuals act in their common interest, rational, self-interested individuals will not act to achieve their common or group interests" (M. Olson, 2002, pp. 2, emphasis in original). In large groups, an individual will calculate his/her benefit and cost of getting some amount of the collective good. If the benefit remains lower than the cost, (s)he will find little incentive and refrain from engaging in collective action with other group members to produce the collective good (M. Olson, 2002, pp. 33-35). Indeed, an individual action of a member in a large group (i.e. farmers) will carry little weight in producing the collective good and whether (s)he acts or not will not be noticeable to the other group members. As the members can get some amount of benefit without any cost, no member will choose to act collectively. From this point, M. Olson (2002, pp. 69-76, 153-159) suggests that large groups such as trade unions and farm bureaus must create economic incentives (i.e. non-collective benefits) together with coercion (e.g. compulsory membership through closed shop mechanisms) to convince potential members of joining or supporting collective actions.

When we read Olson's arguments, a question comes to our mind: can political collective action be taken by a large group? His response is that the ordinary followers of a political party are free-riders, so not engaging in political collective actions such as donating money to the party's coffers, promoting party policies in streets, etc. They are aware that their contribution would not be effective and noticeable, but they could obtain benefits if their party came to power (M. Olson, 2002, pp. 163-164). But what if political collective action came from the people in the political periphery without even a chance to come to power in the foreseeable period, and moreover, the adherents were susceptible to regular coercion by the state? M. Olson (2002, pp. 161-162) (inconvincibly) argues that "mass movements" can be explained in psychological reference to the various qualities of the social structure. Such an explanation is vague, and here we argue that the collective action of mass movements may be better explained by referring to their social capital.

Social capital can be defined as follows (Ahn \& Ostrom, 2008, p. 73):

rely on behavioural and evolutionary game models, and point out that in some cases the assumption of the universal selfishness is valid (Ahn \& Ostrom, 2002, August-September). In other cases a large group of individuals are subject to bounded rationality, that is, "the decision making process was heavily influenced by institutions" such as norms and values, and thus they are "morally constrained" as "norm followers" (Volacu \& Golopenta, 2015, p. 42). All those assumptions point to a high level of cooperation through institutional learning, thus of trust and trustworthiness (Ahn \& Ostrom, 2002, August-September). 
[...] social capital is a set of prescriptions, values, and relationships created by individuals in the past that can be drawn on in the present and future to facilitate overcoming social dilemmas [or collective-action problems]. Those who directly benefit from their own or others' past efforts in building these patterns may be a small or large group. The externalities from the use of social capital may be positive (when a group of neighbours clean up a neighbourhood) or negative to the outsiders (when a gang of youth protect their turf). Social capital reflects a way of conceptualizing how cultural, structural, and institutional aspects of small to large groups in a society interact and affect individual incentives and behaviour and resultant economic and political change. It is a core concept $[\ldots]$ whenever joint endeavours of individuals are critical in achieving a collective goal.

Second-generation theories of collective action have been developed from dynamic or repeated game theory models by which heterogeneous individual preferences take evolutionary forms through interaction. Understanding those theories, "[w]e identify trustworthiness, networks, and institutions as three basic forms of social capital. [...] Trustworthiness, networks, and institutions are capital in the broad sense that they serve as independent inputs to economic and political processes and outcomes" (Ahn \& Ostrom, 2008, p. 72). These are crucial to foster trust between individuals, thereby helping successful collective action for common purposes (E. Ostrom \& Ahn, 2009, p. 22).

'Institutions are the rules of the game in a society or, more formally, are the humanly devised constraints that shape human interaction' by moulding incentives and reducing uncertainty (North, 1990, p. 3). 'Individuals use [them] to organize their activities within and across all forms of organizational and interorganizational arrangements' (Ahn \& Ostrom, 2008, p. 74). Well-functioning institutions are of vital importance to enable cooperation between individuals (instead of exploitation), furnishing information and act as deterrents to level up the likelihood of their reciprocation regardless of high material temptations (Ahn \& Ostrom, 2008).

'Trustworthiness as a characteristic of preferences [emphasis in original] [...] is embedded in a person's intrinsic norms by which one reciprocates others' trust even when material selfinterest does not compel one to do so' (Ahn \& Ostrom, 2008, p. 72). Trust is a 'rational belief about the other's likelihood of reciprocation'; it is not 'a form of social capital' but 'the key link between forms of social capital and outcomes', especially given that individuals could choose to cooperate with others in social dilemmas if they have the belief that others would also cooperate (Ahn \& Ostrom, 2008, p. 80). 
Modern political economic orders require individuals to engage in relationships with people outside their close circle of friends and relatives in one-shot or less repetitive situations. Given the number of altruists in a society is limited, networks are to be established to forge trustworthiness between individuals, disseminating information of their reputation across the network they joined, through repeated actions facilitating cooperation (E. Ostrom \& Ahn, 2009, pp. 26-28). The importance of networks is about their creation of mutual obligations between their members, transformed into mutual trust through reciprocity (Putnam, 2000, p. 18).

E. Ostrom (2001) highlights that, 'social capital is formed over time and is embedded in common understanding rather than in physically obvious structures', and adds that, '[i]t is not easy to see and measure'. ${ }^{35}$ Furthermore, the limited number of studies undertaken constraints our efforts to explain the Kurdish Question in terms of social capital.

\subsection{Intra-Ethnic and Inter-Ethnic Social Capital}

Social capital can naturally take different shapes and entail different norms of reciprocity. Its most important categories are bonding social capital and bridging social capital. Putnam (2000) defines bonding and bridging social capital as follows:

[...] [Bonding social capital is] by choice or necessity, inward looking and tend to reinforce exclusive identities and homogeneous groups. [...] Other networks are outward looking and encompass people across diverse social cleavages. Examples of bridging social capital include the civil rights movement, many youth service groups, and ecumenical religious organizations. Bonding social capital is good for undergirding specific reciprocity and mobilizing solidarity. Bridging networks, by contrast, are better for linkage to external assets and for information diffusion. [...] Moreover, bridging social capital can generate broader identities and reciprocity, whereas bonding social capital bolsters our narrower selves. [...] Bonding social capital, by creating strong ingroup loyalty, may also create strong out-group antagonism. [...] Nevertheless, under many circumstances both bridging and bonding social capital can have powerfully positive social effects. Many groups simultaneously bond along some social dimensions and bridge across others. (pp.20-21).

Linking social capital can be defined "as norms of respect and networks of trusting relationships between people who are interacting across explicit, formal or institutionalized power or authority gradients in society" (Szreter \& Woolcock, 2004). Cross-cutting ties

\footnotetext{
${ }^{35}$ Social capital is more difficult to see and measure in less developed countries than developed countries, and in rural areas than urban areas, because of the weight of informal relations and institutions.
} 
relying on trust and respect between persons such as specialists, officers, service providers, lawyers, etc., can be deemed as an important property of linking social capital, which may foster social harmony, welfare and well-being especially in disadvantaged groups and communities (Szreter \& Woolcock, 2004). As understood, linking social capital helps vertical integration or networking to reach sources and power outside the group (Onyx, Edwards, \& Bullen, 2007).

These forms of social capital should not be considered inherently good. They have a different relationship with power, so involving risks. Bonding social capital cements group-based identity and belonging, which can easily produce intolerance, oppressive acts and unfair advantages. Bridging social capital can give excessive power to reach external assets and networks of skills. When there is a hole between two networks, the mediator who links those networks may gain unfair advantages. The risk that linking social capital poses is to have an overpowering control over society, thus creating inequality among people (Onyx et al., 2007).

For ethnic groups, Miedema (2010) introduces a new category of social capital , depending on the concepts of bonding, bridging and linking social capital: intra-ethnic social capital and inter-ethnic social capital.

Intra-ethnic social capital is formed as a result of the connections between members of the same ethnic group. However, intra-ethnic social capital not only intertwines with "the sum of commonalities such as religion, culture, and language", but also embeds in a network of connections that interact with kinship ties, traditions and norms associated with a common history, namely, "a belief in the distinctiveness of the group", intra-group preferences and emotional attachments, and a shared sense of responsibility that facilitates reciprocity (Miedema, 2010, pp. 67-68). In this manner, intra-ethnic social capital embraces bonding, bridging and linking social capital, and thus more strong, durable and unified connections are vertically and horizontally formed among even remote members through kinship or ethnicity (Miedema, 2010, pp. 65-66, 68-69).

If trustworthiness as a characteristic of preferences is embedded in a person's intrinsic norms that enable or impel her to reciprocate to other's trust (Ahn \& Ostrom, 2008, p. 72), ethnicity must be an important factor imposing itself on a person's preferences and placing itself in it as a strong layer. As mentioned before, Varshney (2003) defines this as value rationality of a member of an ethnic group. In her ethnographic study, Kizilkaya (2014, p. 114) contends that negative discourses or views of political parties can easily influence the decision made by a 
member of an ethnic group: a Kurdish businessman cancels his agreement, thus desisting reciprocity to a company whose owner is a Turkish nationalist. It proves that ethnicity is an important factor that structures a person's intrinsic norms associated with his trustworthiness. This is why a peaceful solution to ethnic problems in a highly ethnically polarised society is difficult to attain.

Individual preferences are layered and structured by ethnicity at various levels, and breaking the layer of ethnicity could be difficult for any state that seeks to assimilate or disintegrate the targeted ethnic identity and its political formation. For example, while the Turkish state authorities could easily convince Kurds to become village guards, strongly associated with tribal social capital rather than ethnicity, they had great difficulty to do this with other Kurds who had a strong ethnic identity. Again, Islamist Kurds have an ideological layer of Islamism in their structure of individual preferences, and thus may politically act in a way compatible with the Islamic brotherhood rather than along Kurdish ethnic identity lines.

Inter-ethnic social capital is formed from bonding, bridging and linking social capital that exist between different ethnic groups, to facilitate the coordination and cooperation between them. The networks of informal and formal relations between individuals and organisations from different ethnic groups are important components of inter-ethnic social capital. The other components are 'norms, understandings, and expectations about rights and obligations' that sustain relationships or end disagreements between ethnic groups (Miedema, 2010, p. 70). The existence of such social capital does not guarantee that tension or hostilities between ethnic groups have vanished but serves the creation of or the improvement in informal and formal institutions that help them coexist without instability and violent vicious circles. This implies a difference between inter-ethnic social capital from bonding and bridging social capital: 'the norms of inter-ethnic social capital largely govern the relationship between ethnic groups at the collective level in the polity' (Miedema, 2010, p. 74).

\subsection{The Ethnic Social Capital of Kurds in Turkey}

The Kurdish population in Turkey, between 12 to 15 million or roughly 18 to $23 \%$ of the total population (F. O'Connor, 2017) are overwhelmingly concentrated in a specific area in eastern Turkey, called North Kurdistan by the Kurds. Others live in central Anatolia and metropolises such as Istanbul, Izmir and Ankara. Such a distribution of the Kurdish population has thus compelled them to interact with various ethnic and religious communities, such as Turks, Turkomans, Arabs, Iranians, Yazidis, Christians, and Jewish (McDowall, 1996, p. 6). Today, Kurds can reside in Turkish-populated areas, speak Turkish, 
access education and employment, run business and marry Turks, though the armed conflict occasionally increases tension between these two ethnic groups. ${ }^{36}$ The inter-ethnic social capital, having strongly formed between Turks and Kurds, is an important factor in explaining why no Turkey-wide civil war has broken out despite the armed conflict that has lasted over three decades. However, their intra-ethnic social capital also explains why no enduring peaceful society has been created. As we indicated earlier, the Turkish state has played an effective role in creating a conservative, nationalist - even chauvinistic - Turkish identity, which hampers the establishment of completely peaceful relationships between Kurds and Turks.

The Kurdish ethnic identity has remained fragmented because of the existence of various tribal identities, ideologies and differences in cultural characteristics such as language, beliefs and religion (McDowall, 1997). Nevertheless, the increasing intimacy among Kurds from different countries as a result of globalisation and wars in Syria and Iraq, assimilation policies and the ban on the use of the Kurdish language have created a common identity among Kurds and strengthened the intra-ethnic social capital, despite a lagging economic and institutional integration (Kurubas, 2008).

Even among young Kurds whose families have often integrated with Turks outside Kurdishpopulated areas, there is still a strong Kurdish identity. Kizilkaya (2014, p. 124) reports from an interview with a Kurdish young:

I thought that the [ethnic] identity was not important among us; our material circumstances were good. We lived an isolated life [from the Kurds in the SAR]. The case of Ahmet Kaya became a turning point in my life. My family got deeply shocked over what he faced and his death. My consciousness about Kurdishness started [with this incident]. I wanted to learn Kurdish. [...] Then, I got into learning the Kurdish history $[\ldots]$.

Weak governance structures, lack of public investments and state failures in providing basic economic and social services cement intra-ethnic capital in developing countries as ethnic group members step into this services vacuum (Miedema, 2010, p. 77). In Turkey, developmental problems induced the revival of Kurdish nationalism, especially among the Kurds that had migrated to urban areas. Nevertheless, widespread poverty and a low level of

\footnotetext{
${ }^{36}$ The study of Kizilkaya (2014) scrutinises lives of ordinary Kurds who migrated to Konya centuries ago, one of the most conservative nationalist cities in Turkey. The study is important to show that Kurds have been able to develop robust inter-ethnic social capital with Turks, and strong intra-ethnic social capital even when they have been remote from mostly Kurdish-populated areas for centuries.
} 
capital have not allowed networks of ordinary Kurds to provide a wide range of services to each other. And since the capacity of Kurdish tribal elites to provide economic insurance has also eroded over time (Gultekin, 2013), Kurds are impelled to call for state support. Still, there is a widely shared acceptance that solving the economic problems is not sufficient to address the Kurdish question, if the Kurdish identity is not recognized (Kizilkaya, 2014, pp. 154-157).

Nevertheless, kinship ties and ethnic identity can function as an interface for socio-economic security such as finding shelter and a job, ensuring security, settling permanently and assisting those who reside in rural areas (Kurban \& Yegen, 2012; The IPS at Hacettepe University, 2006, p. 73). This has resulted in a concentration of the Kurdish population in some neighbourhoods in predominantly Turkish-populated urban areas, creating strong social but informal networks.

In the SAR, rural life has been transformed into a hybrid rural-urban life. The old have returned to their villages after the end of the armed conflict in 1998 whereas the young still dwell in urban areas. In the rural-urban life, the old and the young in a family are exchanging agricultural goods and urban-based goods to support each other's lives (Jongerden, 2015, pp. 336-337). As a result, intra-ethnic social capital is increased in the network of family, relative and neighbours among Kurds.

\subsection{The Formation of Kurdish Ethnic Social Capital in the Kurdish Question}

This section explains how Kurds have formed ethnic social capital after the foundation of the Republic of Turkey in 1923 and turned this subsequently into political collective action. It also discusses what policies the Turkish state has adopted in response to this form of social capital.

When the republic was founded, Mustafa Kemal Ataturk - representing the interests of the military-bureaucratic class - established a new constitutional regime based on three principles: republicanism (centralisation), secularism, and a nation-building project based on Turkishness. These principles, however, contradicted the nascent Kurdish nationalist collective identity, which was mainly based on tribal kinship, Islam and Kurdishness (A. V. Koçal, 2014).

The exclusion of Kurdish tribal elites from the dominant coalition further provoked an angry response. In the $16^{\text {th }}$ century, Kurdish tribes had obtained considerable autonomy from the Ottoman central administration in exchange for protecting the territory against Iran 
(Bruinessen, 1992, pp. 157-161). However, they gradually lost their autonomy due to coercive policies of the Ottomans in the $19^{\text {th }}$ century who advanced their centralisation project. When the new republic completely terminated the Kurdish autonomy and the caliphate, prohibited the Kurdish language in public areas and implemented forced exile and resettlement, a Kurdish nationalist rebellion erupted, tapping into the social capital of the Kurdish tribal networks (Bruinessen, 1992, pp. 281-299).

Employing landless people on their lands, the exiled tribal leaders had been providing their members, by hook or by crook, with physical, economic and financial security via an informal credit mechanism (Besikci, 1970, pp. 106-107). But no modern credit mechanisms nor any social and economic security institutions were established by the government to help people to sustain their agricultural activities during the absence of the tribal leaders (Besikci, 1970, pp. 30-31). The tribal leaders, in the end, came back to their hometowns, restored their legitimacy and established political relationships with local and national authorities to protect their positions (Besikci, 1970, pp. 310-311). Yet, the war destruction and disruptions in the feudal system had a significant economic impact on Kurdish society, contributing to the widening regional development disparity between eastern and western Turkey.

In 1950 when the DP government came to power under a multi-party political system, they sought to satisfy the interests of large landholders in exchange for political support, providing imported agricultural inputs and machinery, favourable agricultural prices and subsidies (Aydemir, 2000, pp. 218-219; Başkaya, 1991, p. 173; Keyder, 1979, p. 57; Robinson, 1952). The mechanisation of the agricultural sector, however, tilted the agricultural structure away from sharecroppers and smallholders across Turkey (Robinson, 1952) but arguably mostly in the SAR - mostly populated by Kurds and Arabs and with a highly unfair land distribution (Besikci, 1970, pp. 60-61). Many sharecroppers were forced out of agriculture during the diffusion of mechanisation. Some resisted the tribal leaders and resettled on marginal land. Others, living in border towns, started smuggling various agricultural and agro-industrial goods. Finally, some migrated to regional urban areas, but with limited investments and industrial activity many faced hardship (Besikci, 1970, pp. 127-130, 199-202, 383). ${ }^{37}$ Tribal leaders with large plots abandoned the sharecropping system for capitalist agricultural production in order to generate more surplus (Besikci, 1970, pp. 122-123). Increased

\footnotetext{
${ }^{37}$ Given that the urbanisation level is taken as an indicator of development, the average urbanisation level for Turkey was around 34.5 per cent in 1965 but 27.2 per cent for East Turkey. If we exclude small towns that were hardly indistinguishable from a large village, the urbanisation level was 12.3 per cent in the latter (Besikci, 1970, pp. 46-47).
} 
agricultural surplus and usury income from informal credits granted to smallholders were invested by tribal elites in urban commercial and service sectors as well as in rent-creating activities (Besikci, 1970, pp. 94-96, 135-137).

As Besikci (1970, p. 124) however argues, the surplus generated in eastern Turkey was significantly transferred to western Turkey in a manner that intensified less development of East Anatolia. In those years, public investments made by the state raised the dependency of Kurds to the central political power, and that semi-feudal institutions were not replaced but distortedly amalgamated with capitalist institutions (Besikci, 1990, p. 90). In political terms, the position of Kurdish "sovereign class" - large landholders, tribal leaders and sheiks - in the dominant coalition, always remained lower than that of the Turkish elites (Besikci, 1990, pp. 90-94). Therefore, the social capital formed by Kurdish and Turkish elites after 1950 - mostly relying on linking social capital between the tribal social capital and the state - perpetuated the less development of the SAR.

Contrary to the social capital formation between Kurdish and Turkish elites, intra-ethnic social capital among Kurds in the political-economic periphery and inter-ethnic social capital between them and their Turkish counterparts did develop. The former explains the emergence of the PKK; the latter explains the relationship between Turkish leftists and the Kurdish political movement.

After the 1960 military coup and the introduction of the 1961 Constitution that safeguarded democratic rights, leftist movements in Turkey grew in strength due to increased (class) awareness, in return enhanced by improvements in universal education in Turkey (Yavuz, 2001). In those years Kurdish nationalism re-flourished in Turkey as Kurds gained insight into their developmental backwardness and cultural differences between eastern and western Turkey as a result of migration (Bruinessen, 1992, p. 32). Against the state that had perceived Kurds as "prospective-Turks", a counter-perception extended that Kurds may not be Turks (Yegen, 2009). The nationalist sentiments of Kurds coincided with a period - 1960s and 70s during which leftists and peasant revolts became quite common across developing countries. Many talented but poor Kurds, who received university education in west Turkey, interacted with Turkish Marxists and grouped together to question the economic and political status of Kurds, even joining the Turkey's Workers' Party, the Confederation of Revolutionary Workers Unions and the Federation of Revolutionary Youth (Romano, 2006, p. 42). 
Fervent Kurdish leftists and nationalists also endeavoured to turn intra-ethnic social capital into political collective action, organising "meetings of the East" in Kurdish-populated eastern cities to foster national consciousness, and set up the Revolutionary Cultural Centres of the East movement (Gunes, 2012; Yavuz, 2001). Though many leftists and Kurdish organisations were closed down by the state after the 1970 coup, they re-activated themselves under different organisations. The prominent Kurdish political networks throughout the 1970s were the Socialist Party of Turkish Kurdistan, the PKK, Rizgarî, the Kurdistan National Liberationists, Kawa, Ala Rizgarî and Tekoşin.

After the 1980 military coup, the backbone of leftist movements was broken by the military and legal authorities in Turkey. Furthermore, Kurdish nationalism and religion-based relations in the Kurdish-populated areas were oppressed via supressing cultural identities through assimilation policies. But these policies had the opposite effect: the national awareness of Kurds actually increased and the PKK established its organisational and military capacity within political and cultural structures (Yavuz, 2001).

As a result of the disintegrated sharecropping system, a large group of Kurds migrated to urban areas and established relationships beyond the control of the tribal system and boundaries of their tribal identities (Romano, 2006, pp. 41-42). Other decisive factors behind the migration were the law of diminishing returns, which effects were exacerbated by Islamic inheritance law (Bruinessen, 1992, p. 16), and the forced displacement and negative political economic conditions inflicted by the armed conflict between the PKK and the Turkish state. It is difficult to find detailed studies depicting how Kurds have structured their national identity in modern everyday life. We can, however, observe that modern urban lifestyles have helped the informal institutional formation of the national Kurdish identity in the juxtaposition of weakening tribal sense and norms of belonging. It has impelled Kurds develop trust, reciprocity, institutions and networks, thus intra-ethnic and inter-ethnic social capital.

\subsection{The Military Narrative and the Development Narrative around the Kurdish Question}

In this section, we will discuss how the state has approached the Kurdish Question after the emergence of the armed conflict with the PKK. Note that the Turkish state does not accept the Question as coming from lack of democracy, an argument that the Kurdish political movement proposes. As seen in the previous section, the state has significantly blocked or banned their participation into the country-level decision-making processes. 
The Military Narrative: The PKK formulated its political standpoint under the banner of a liberation movement, based on a socialist economic order and nationalism of the oppressed nation to overcome social injustice and political and cultural repressions. They were supported by landless farmers, smallholders, university youth, the urban petite bourgeoisie, and young, urban and socio-economically excluded Kurds (Ozcan, 2006, p. 205; Yavuz, 2001). The leadership and militant cadres of the PKK were composed of both Kurds and Turks (Kucukaydin, 2016, p. 26), suggesting that the Kurdish political movement had strong inter-ethnic social capital.

After the 1980 coup, the military increasingly militarised eastern Turkey and oppressing leftist or Kurdish organisations in the political arena. A few years later, in 1984, the PKK launched its first armed attack on Turkish army, and they employed a successful rural-based guerrilla war strategy from 1984 to 1993, and swelled its ranks in a ten year period to around 12000 militants, based in mountain camps. Furthermore PKK supporters or militias in villages and towns were roughly 8 or 10 times more that figure (Pamukoglu, 2003, p. 60). At first, the army, deploying a conventional military strategy, only defended their posts but was not capable of defeating the PKK (Pamukoglu, 2003, pp. 35-36). Later, in the 1990s, they gradually changed their mindset and strategy, reorganised the units, acquired better equipment and conducted an integrated counter-insurgency strategy (Jongerden, 2015, pp. 83-92). The most important features of this strategy were the aggressive use of the village guard system ${ }^{38}$ - based to a large extent on Kurdish tribal social capital -, and of 'forced village evacuations ${ }^{39}$ in order to isolate the PKK from its rural network, important for logistics, shelter, finance and recruitment (Gurcan, 2015; Jongerden, 2010b).

Two narratives dominated the Kurdish Question at that time: a military narrative and a development narrative. As Yegen (1999) expresses, the Question was discursively constructed in the military narrative as a political reaction, banditry or tribal resistance and in the development narrative as regional backwardness (but not as an ethno-political question or a democratisation question).

The military narrative considered an armed response to eliminate the PKK necessary for the integrity of the state. However, it was useful to obstruct other threatening opponents to the military bureacuracy dominating Turkey's politics.

\footnotetext{
${ }^{38}$ The total number of village guards operating with the Army was raised from 800 to approximately 55000 between 1984 and 1994 (Gurcan, 2015).

${ }^{39}$ Local officials presented two options: become village guards and stay in your village or leave your village (Yukseker, 2008, p. 150).
} 
When civilian governments, formed by centre-left and centre-right parties, increasingly lost their popularity in the eyes of ordinary citizens because of political fragmentation (Bozarslan, 1996, pp. 140-141) and their inability to address a wide range of economic and political problems (R. Olson \& Bozdaglioglu, 1996, pp. 163-164), the rise of the pro-Islamic WP took place. This alarmed the military bureacracy as the protector of secularism (Bozarslan, 1996, pp. 140-141, 145). Anti-militarism was limited to a small group of intellectuals and human rights advocates at the time (Cizre-Sakallioglu, 2003). The military narrative, therefore, was readily accepted for fear of disintegration of the country; the politicians accusing each other attempted to leverage this fear for political ends (Bozarslan, 1996). In such a political setting, the military narrative greased the wheels to extend the conventional political autonomy of the military bureaucracy from fighting with the PKK to controlling civilian politics more tightly (Cizre-Sakallioglu, 2003; Gurbey, 1996, pp. 12-21). The political power of the army reached so far that they were able to remove the pro-Islamic WP and the True Path Party government in 1997 by re-engineering the civil political structure with the support of a wide range of urban secular people (Cizre-Sakallioglu, 2003; Cizre \& Çinar, 2003).

The Development Narrative: This narrative is an effort to frame the Kurdish Question as a problem coming from development imbalances in eastern Turkey, disregarding the link between the Question and lack of democracy in Turkey (Cizre-Sakallioglu, 2003) and ethnopolitical demands of Kurds (Kizilkaya, 2014, pp. 101, 105). Our research may be criticised for the same reason, yet we acknowledge that a democratic solution to the Question is required. As mentioned in the previous chapter, the democratic participation of peripheral movements - including the Kurdish political movement- and the recognition of democratic rights are required.

A key attempt by the Turkish state to solve the Question from a development approach is the the GAP (see Chapter 4). The project was first planned in 1977 with the integration of projects - such as dams, reservoirs and hydroelectric plants - in the lower Euphrates and the Tigris Basin (GAP-RDA, 1993b) but was turned into a multi-sector, integrated regional development project in 1989. Economically, the main purpose was to foster agricultural development of the SAR through irrigation investments, to then introduce industrialisation and ultimately close the developmental gap between eastern and western Turkey.

One of the aims of the GAP was to increase opportunity costs of joining the PKK through development. Development here acts to solidify military counter-insurgency strategies (Ozok, 2004, p. 49). The state bureaucracy and governments have frequently interpreted the 
development narrative with the military narrative for this reason. Indeed, state officials have constantly forged a link between security and development with regards to the Question (Bilgen, 2014). For example, Mehdi Eker, an ex-minister responsible for agriculture, expressed, "there are socio-economic problems that the terrorist organisation [the PKK] exploit; we point out that solving those socio-economic problems through the GAP Action Plan is crucial" (2010, 23 June). The GAP Regional Development Administration Directorate (1993a, p. 1) (GAP-RDA) shows how the GAP will purposefully instrumentalise development for security:

Putting into practice the investments of the South-eastern Anatolia Project (of the GAP), that would give momentum to the regional economy, particularly agricultural investments, will contribute to the solution of problems of unemployment and economic backwardness, and this will largely eliminate economic and social sources of terrorism [emphasis added].

The GAP was also expected to change the social structure of Kurds. Taking a post-modernist perspective, Ozok (2004) argues that the state conceives a dichotomy between tradition and modernity. From this perspective, developmental efforts in the region are carried out to tackle the tradition or tribal social formation which are seen as barriers to modernisation. Jongerden (2010a) asserts, "the GAP could turn Kurds into Turks", transforming traditional, tribal-based agriculture into state-dependent, modern and market-oriented agriculture. However, the intention of the Turkish state to turn Kurds into Turks has remained predominately theoretical and discursive without significant outcomes. The state identity politics related to economic development has not gone beyond vulgar practices such as demolishing Kurdish heritage by constructing dams (Jongerden, 2010a), inciting strong reactions among Kurds. Kurds have engaged in modernisation and market-based agricultural transformation, but they have not turned into Turks through their strong intra-ethnic social capital. The expansion of the Kurdish political movement in the 2000s and 2010s proves this point.

Kurds have long not owned the negative perception of modernisation. As explained earlier, the Kurdish Question itself is a result of Turkey's modernisation process. The Kurdish political movement is a modern movement, which has, since the 1960s, fought against traditional or tribal social formations. They ideologically accepted a dichotomy between the oppressor and the oppressed rather than modern and traditional. Once they defined the issue in this way, both the state and tribal leaders became their antagonists. For example, they promoted land reform against tribal leaders to solve the problem of unfair land distribution in 
the SAR, but the state never got involved in this, afraid to harm the interests of large landholders, including tribal leaders (McDowall, 2004, pp. 591-592). In other words, political realities forced the state to act against modernisation, so supported tribal leaders in the armed conflict.

Modernisation itself has attraction. Even tribal leaders showed their willingness in the 1950s to engage in modern agriculture to generate more surplus. They later envisaged the GAP as an opportunity to increase their agricultural income as well as to steer their investments into industry (Savas, 1998).

Furthermore, Kurds are confidently welcoming public investments despite the political intentions of the state. A member of parliament from the pro-Kurdish party explains (Düzel, August 6, 2012):

[...] All the cities in Kurdistan are backward. [...] You have lived together so far; all have happened through your taxes, water, dams and natural resources, too. If they set up a factory in the GAP, you, just benefit from it as Kurds. Separating from Turkey will economically not be beneficial for Kurds. Also, Turkey has experiences in functioning state and law. It has political experience. These are all beneficial to Kurds.

\subsection{Conclusion}

In this chapter, we critically assessed Olson's collective action theory, neglecting the analysis of political collective action. Taking the case of Kurds, we proposed that the political collective action of large groups could take place if they have developed social capital. Afterwards, we discussed the social capital theory of Ostrom and her colleagues and Miedema's adaptation of social capital to ethnicity to understand the Kurdish political movement. This discussion revealed that ethnicity is an important factor that structures a person's intrinsic norms associated with his trustworthiness, so creating an ethnic-based value rationality. For this reason, a peaceful solution to ethnic problems in a highly ethnically polarised society is difficult to attain.

Another suggestion is that the formation of Kurdish ethnic social capital has nullified the effects of the policies designed by the Turkish state to transform their identity into Turkishness. Kurds have developed a significant level of intra-ethnic and inter-ethnic social capital, which enable them amplify their political movement within themselves and extend it to other groups. 
More importantly, the formation of social capital has over time induced the transformation of the tribal Kurdish identity into the modern Kurdish identity, and created two main groups: conservative Islamists Kurds and secular nationalist Kurds. Today, the former group generally support the JDP government under Islamic brotherhood whereas the latter comprise the Kurdish political movement encompassing the pro-Kurdish parties and the PKK.

The armed conflict between the PKK and the Turkish state shaped the political terrain. The military bureaucracy strengthened its power and dominated Turkey's politics in the 1990s through the military narrative. As we will discuss later, the political, economic and social costs of the armed conflict at the same time undermined their power and paved the way for the rise of the conservative periphery.

The development narrative is the derivative of the political conflict between the Kurdish movement and the Turkish state. It is used to mask the demand of democratic rights proposed by Kurds. Apart from this, development is instrumentalised for the elimination of economic reasons of championing the PKK. Making Kurds alienated from it is regarded as the main aim. The subtle aim is to turn Kurds into Turks by changing their mindset via societal changes. We have showed that this approach has not yielded expected results for the state. Kurds are seemingly willing to attract public investments and adopt modern institutions, which are believed to develop their political power and social capacity. 


\section{Chapter 4: Turkey's Political Economy and the South-eastern Anatolia Region's Agriculture}

\subsection{Introduction}

This chapter will discuss Turkey's political economy and neoliberal agricultural policies covering the period between 1980 and 2001. Special attention will be given to the politicaleconomic terrain that helped the rise of Islamist political movement. This will help to better understand the challenging relationship between the military-bureaucracy and the JDP government, and the Kurdish Question between 2002 and 2017.

The ARIP, a dramatic measure to advance neoliberal agricultural transformation, and modifications in agricultural policies without diverting the neoliberal path will be discussed to provide further insight into Turkey's agriculture in nearly the last two decades.

In the final section, we will introduce the GAP and discuss its content and transformation in the neoliberal period. In doing this, the argument that the SAR is a relatively less developed region in Turkey will be supported by evidence, and further details about the SAR's agriculture will be provided.

\subsection{Turkey's Political Economy and the Neoliberal Agricultural Transformation between 1980 and 1989}

Though protectionist economic policies enabled Turkey to succeed in industrial development to a certain degree (Şenses, 1990, pp. 62-63; Taylor, 1990, p. 270), economic bottlenecks in the 1970 s led to a change in political economic mindset. The outward-looking strategy adopted was initially underpinned by a structural adjustment programme initiated in $24^{\text {th }}$ January, 1980, which aimed to create surplus for export by lowering wage levels and reducing total national demand (Yeldan, 2006, p. 44). This was a radical neoliberal transformation (Yasli, 2014, p. 33), which 'chang[ed] and redefin[ed] the policy parameters regulating and shaping income distribution against labor in general' (Boratav, 1990). As Harvey (2007, p. 90) states, the degree of transitioning to neoliberalism in the world relied on 'the balance of class forces' and 'the degree of dependency of the capitalist class on the state'. Given that no political party obtained a majority within a political environment frustrated by civil disturbance and economic turmoil in the 1970s, and that there were politically active working class networks in Turkey, the implementation of the programme seemed extremely difficult. The military-bureaucratic class therefore applied a level of coercion to establish a rule for carrying out neoliberal policies, especially by disorganising 
networks associated with the working class and leftists (Bayar, 1996) and letting business associations getting more involved in shaping policies (Boratav, 1999, p. 75).

Internal factors were essential for the transition to a neoliberal economic order. Because the capital accumulation process did not work effectively in the 1970s, the secular bourgeoisie sought to combine capital-intensive modern industries with their labour-intensive, exportoriented industries (Aydin, 2005, p. 42). Given that Turkey's technological capacity was low, this required integration with world capitalism through trade and partnerships (Aydin, 2005, pp. 42-43), but at the same time the bourgeoisie continued to rely on the state, obtaining export subsidies and tax exemptions (Ş. Pamuk, 1987, pp. 163-165). The Islamist bourgeoisie, which had mainly organised itself in small and medium-scale enterprises (Savran, 2015, p. 45), too, gained substantial advantage during this period, selling their goods to domestic and global companies through a subcontracting and outsourcing format (Yasli, 2014 , p. 23). Savran (2015, p. 45) argues that this fraction within the bourgeoisie pointed to an intra-class conflict, reflected in the political domain with the initiation of the first Islamist party in 1972. Ultimately, those who economically lost during this period were farmers and workers (Boratav, 1990).

Turgut Ozal, a former prime minister of Turkey, managed the neoliberal transformation between 1980 and 1991, as the leader of the Motherland Party after 1983. The main aim of agricultural policies during his leadership was to fully replace pre-capitalist relationships in agriculture with more systematic and organised capitalist relationships (Oral, 2006, p. 63). A dramatic change in agriculture therefore occurred between 1980 and 1989 through structural and sectoral adjustment loans (as well as institutional and technical assistance) granted by the WB on condition that certain measures (listed in Table 4.1) were taken (Oral, 2006, p. 69). Table 4.1 displays the main characteristics of the agricultural policies implemented in the period of 1980-1989. 


\begin{tabular}{|c|c|}
\hline Main Points & The Details of the Implementations \\
\hline $\begin{array}{l}\text { Subsidised } \\
\text { Purchases }\end{array}$ & $\begin{array}{l}\text { * Subsidised purchases continued but were greatly kept lower in value. The numbers of the } \\
\text { agricultural crop types subsidised were reduced from } 24 \text { to } 10 \text { within a decade. } \\
* \text { Private companies were allowed to operate in the domestic agricultural commodity } \\
\text { markets in which state-owned agro-industrial companies had kept monopoly rights before. }\end{array}$ \\
\hline Prices & $\begin{array}{l}\text { * Floor prices for crops were kept lower in real terms to render exporters and agro- } \\
\text { industries competitive in international markets. } \\
\text { * Increases in floor prices for crops were considerably kept behind increases in input } \\
\text { prices. }\end{array}$ \\
\hline $\begin{array}{l}\text { Trade } \\
\text { Liberalisation }\end{array}$ & $\begin{array}{l}* \text { Taxes and fees on imported food were lessened in } 1984 \text { so that they could spike in } \\
\text { volume in the following years. }\end{array}$ \\
\hline Loans & $\begin{array}{l}\text { * Subsidised agricultural loans were reduced in amount. The share of agricultural loans in } \\
\text { total loans therefore dropped by around } 63 \text { per cent. } \\
\text { * Interest rates were allowed to be set by market actors. For agricultural loans, the interest } \\
\text { rate mounted from } \% 16 \text { to } \% 46.5 \text { in almost a decade; loan terms were decreased. }\end{array}$ \\
\hline Input Subsidies & $\begin{array}{l}\text { * Input subsidies were gradually lifted. } \\
* \text { Input prices were allowed to be set by market actors. Consequently, the index of sale } \\
\text { prices of crops increased } 41 \text { times in nominal terms between } 1980 \text { and } 1990 \text { but the index } \\
\text { of input prices } 64 \text { times. }\end{array}$ \\
\hline Privatisation & $\begin{array}{l}* \text { The distribution, production and sale of inputs to farmers were completely left to private } \\
\text { actors. } \\
\text { * The state companies dealing in farm inputs were privatised. }\end{array}$ \\
\hline $\begin{array}{l}\text { Organisational } \\
\text { Changes }\end{array}$ & $\begin{array}{l}* \text { The state greatly abandoned production, distribution and sale activities in agriculture. } \\
\text { * The organisational structure of the Ministry of Agriculture was changed, and thus, they } \\
\text { started to only monitor and regulate the sector. }\end{array}$ \\
\hline
\end{tabular}

Table 4.1 The Main Points and the Details of the Agricultural Transformation Carried out in the 1980s (Oral, 2006, pp. 63-69; M. Öztürk, 2012, p. 68)

Unlike most African countries, Turkey had become one of the few less developed countries that had achieved self-sufficiency in food production through protectionist policies as earning foreign exchange from agricultural export and supplying raw materials to the industry (Cakmak \& Yeldan, 1994, p. 225; Luan, Cui, \& Ferrat, 2013). ${ }^{40}$ These successes were not deemed sufficient. "The $24^{\text {th }}$ January Decisions", terminating protectionist policies in agriculture, were introduced but could not yield the expected results.

40 Turkey reached the frontier model in agriculture in the $1960 \mathrm{~s}$, that is, there were no arable lands to be exploited. Increases in productivity in the first half of the 1970s therefore emanated from increased agricultural fixed capital investments and technological development programs (Cakmak \& Yeldan, 1994, p. 225). 
The average agricultural growth rate in the $1980-89$ period $(0.68 \%)$ was lower than that of the period 1969-79 (around 1.59\%) (The World Bank, 2017). And agricultural productivity remained the same between 1981 and 1998, unlike most other developing countries which experienced growth (The World Bank, 2000, p. 298).

Agriculture's domestic terms of trade is the ratio of prices of agricultural crops or food to prices of industrial goods. If 1968 is taken as a benchmark 100, it rose to 131 in 1978 but dramatically dropped to 70 by 1988 (Boratav, 2009). Clearly, it seems that industrialists took advantage of worsening agriculture's domestic terms of trade at the expense of farmers. Indeed, agriculture's domestic terms of trade with respect to industrial-based input prices dropped from the benchmark of 100 in 1976 to 60.8 in 1982 (Boratav, 1999, pp. 46-47).

Reductions in real prices received by farmers did not benefit urban consumers but merchants who increased their profit margin and the Treasury which saw a reduction in the costs of subsidised purchases (Boratav, 1999, pp. 48-49). From Bates's standpoint stated in "Markets and States in Tropical Africa", producers of exportable cash crops should have received more profit without any state interventions under free market conditions (Bates, 2005, pp. 11-29). Yet, looking at tobacco and cotton, Boratav (1999, p. 49) shows that the differential between export prices of the crops and the prices received by farmers grew by around $180 \%$ between 1979 and 1989, at the expense of farmers, through trade liberalisation and liberalised exchange rates. Moreover, agricultural export rose by $42 \%$ in the $1980-89$ period whereas agricultural import spiked 24.8 times (from 51 to 1318 million US dollar), and foreign trade surplus in agriculture ended up contracting by $33 \%$.

It is obvious that the roll back of state interventions from agriculture adversely affected the rural people. The economic shock along with the ongoing effects of diminishing returns in agriculture induced migration from villages to the suburbs of industrial cities. Those who settled in suburbs tended to become workers in the informal sector and mostly fell into poverty, with social welfare expenditures reduced under the neoliberal transformation (Buğra, 2008, pp. 200-202). A struggle eventually emerged in the 1990s between people who originated from poorer families of small towns and villages with conservative values, and those who had settled in urban areas long time ago. This struggle was about who would occupy 'the mid- and senior-level posts within the state apparatus and [...] jobs in the private sector' (Savran, 2015, p. 46). As Savran (2015, p. 46) articulates: 'this second dimension of intraclass struggle really converts what would otherwise have remained a friction within the class of capitalists into a more mass phenomenon [...].' Islamic networks acted as 
associations of interests which banded together working classes with conservative values and Islamic bourgeoisie (Savran, 2015, p. 59). This struggle within the working class coincided with the struggle between the Islamic and the secular bourgeoisies, which would come to influence politics in the 1990s.

\subsection{Turkey's Political Economy and the Neoliberal Agricultural Transformation between 1989 and 2000}

The neoliberal economic transformation continued between 1989 and 2000, but experienced some problems. The new capital accumulation regime stagnated in 1988-89, showing mismatches with the export-based industrialisation model relying on the private sector. That is, the share of manufacturing investments in total private investments (around 30\%) hardly improved by 1987 and even contracted (24\% in 1993) over the following years, as a result of investments directed to the construction sector, which was of course unable to earn foreign exchange. Given reduced public investments, Turkey's economy returned to low growth and high inflation rates (Yeldan, 2006, p. 48).

To overcome this impasse, new institutions and deregulations were put into effect, that is, full convertibility of the Turkish lira and free flows of international capital into Turkey's recently founded financial markets were allowed by the government (Önder, 1998). The institutional change had important political and economic effects. Short-term capital flows helped to preclude balance of payment difficulties, but their excessive flows overvalued Turkish lira and encouraged consumption and imports. Particularly, the improving ability to import was used by various governments for political populism to remain in power (Yeldan, 2006, pp. $40,50-51,55)$. The combined negative effects of neoliberal populism ${ }^{41}$ showed themselves in "mini cycles of growth-crisis-stabilisation" (Aydin, 2005, p. 119), where investments were not adequately channelled into productive areas such as the manufacturing industry (Oral, 2006, p. 85). Abrupt outflows of short-term capital, and unmanageably swelling public debts, which came from increased interest rates and raises in real wages in the public sector and in rural income transfers, were the main reasons of the crises or recessions of 1994, 1998-99 and 2001 (Yeldan, 2006, pp. 50, 53). Note that all of them were attempted to be overcome through typical stabilisation or structural adjustment policies.

\footnotetext{
${ }^{41}$ Neoliberal populism is a term that brings two elements together. The first one relates to neoliberal economic policies, which aims at phasing out state interventions and leaving economic efficiency and growth to free markets. The second one refers to the way that the economy is reformed, that is, "reforms tend to be initiated in a top-down fashion, often launched by surprise and without the participation of organized political forces"; see also "liberal policies with illiberal politics" (Öniş, 2004).
} 


\begin{tabular}{|c|c|c|c|c|}
\hline The Name of the Party & Political Position & Ideology & Political Leader & Active Period as a Leader \\
\hline \multirow{2}{*}{ The Motherland's Party } & \multirow{2}{*}{ Centre-Right } & \multirow{2}{*}{$\begin{array}{c}\text { Liberal } \\
\text { Conservatism }\end{array}$} & Turgut Ozal & Until 1991 (Became President) \\
\hline & & & Mesut Yilmaz & Between 1991 and 2001 \\
\hline \multirow{2}{*}{ The True Path's Party } & \multirow{2}{*}{ Centre-Right } & \multirow{2}{*}{$\begin{array}{c}\text { Liberal } \\
\text { Conservatism }\end{array}$} & Suleyman Demirel & Until 1993 (Became President) \\
\hline & & & Tansu Ciller & Between 1993 and 2001 \\
\hline \multirow{2}{*}{$\begin{array}{l}\text { The Social Democratic Populist } \\
\text { Party (Joined in the RPP in 1995) }\end{array}$} & \multirow{2}{*}{ Centre-Left } & \multirow{2}{*}{ Social Democracy } & Erdal Inonu & Until 1993 \\
\hline & & & Murat Karayalcin & Between 1993 and 1995 \\
\hline \multirow{2}{*}{$\begin{array}{l}\text { The Rebuplican People's } \\
\text { Party }\end{array}$} & \multirow[t]{2}{*}{ Centre-Left } & \multirow{2}{*}{$\begin{array}{l}\text { Kemalism \& Social } \\
\text { Democracy }\end{array}$} & Deniz Baykal & $\begin{array}{l}\text { Between } 1995 \text { and } 1999 \\
\text { Between } 2000 \text { and } 2010\end{array}$ \\
\hline & & & Altan Oymen & In 1999 and 2000 \\
\hline The Democratic Left Party & Centre-Left & $\begin{array}{c}\text { Kemalism \& Social } \\
\text { Democracy }\end{array}$ & Bulent Ecevit & Between 1989 and 2004 \\
\hline The Welfare Party (Banned in 1998) & Far-Right & Islamic Conservatism & Necmettin Erbakan & Between 1987 and 1998 \\
\hline The Virtue Party (Banned in 2001) & Far-Right & Islamic Conservatism & Recai Kutan & Between 1997 and 2001 \\
\hline $\begin{array}{l}\text { The Nationalist Work Party } \\
\text { (Joined in the NMP in 1993) }\end{array}$ & Far-Right & Ultra Nationalism & Alpaslan Turkes & Between 1987 and 1993 \\
\hline The Nationolint Mourment Dortu & Far-Right & Ultra Nationalism & Alpaslan Turkes & Between 1993 and 1997 \\
\hline Ine Nationalist Movement Party & Far-Right & Ultra Nationalism & Devlet Bahceli & Since 1997 \\
\hline
\end{tabular}

Table 4.2 Prominent Political Parties in Turkey between 1987 and 2001

Some major political events also shaped Turkey's political economy in this period. The leaders who had been prohibited from engaging in politics after the 1980 military coup were granted the right to resume their political lives as a result of the 1987 referendum. Afterwards, the emergence of diverse political parties in terms of ideology (see Table 4.2) and policies mounted political rivalry throughout the 1990s (Secor, 2001). As no party could get the majority of the seats in the parliament, coalition governments (see Table 4.3) were supposed to rule the country, with their composition frequently changed. In this political environment, agricultural supports were, to some extent, expanded by governments prior to elections to assure rural votes (Aydin, 2005, p. 101).

\begin{tabular}{|c|c|}
\hline Coalition Governments & The Pe riod of Se rvice \\
\hline The True Path's Party \& The Social Democratic Populist Party & November1991 - October 1995 \\
\hline The True Path's Party \& The Rebuplican People's Party & October 1995 - March 1996 \\
\hline The Motherland's Party \& The Democratic Left Party & March 1996- April 1996 \\
\hline The Welfare Party \& The True Path's Party & April 1996- June 1997 \\
\hline $\begin{array}{c}\text { The Motherland's Party \& The Democratic Left Party } \\
\text { The Democratic Left Party \& The Motherland's Party } \\
\& \text { The Nationalist Movement Party }\end{array}$ & Mane 1997 - May 1999 \\
\hline
\end{tabular}

Table 4.3 Coalition Governments in Turkey during the 1990s

Populism remains inadequate to understand the expansion of agricultural support. According to Aydin (2005, p. 159), 'the state was capable of liberalising the economy on all fronts; [...] 
the financial and industrial sectors were given priority treatment.' There were far fewer benefits from agriculture to be reaped by the bourgeoisie. More importantly, the unsustainability of neoliberalism in less developed countries alarmed the IMF and the WB, and therefore policies for coping with poverty, particularly among the rural population, were suggested to pre-empt adverse political outcomes which would hamper the operation of markets (Buğra, 2008, p. 78). ${ }^{42}$ Indeed, the socio-economic repercussions of neoliberalism manifested themselves in the rise of leftist movement, and ended the rule of the Motherland Party in 1991. The True Path Party and the Social Democratic Populist Party, which had promised improvements in social welfare of the working class and agricultural producers, entered a coalition government. However, they could not abandon neoliberal economic policies and commitments to international organisations working within the boundaries of the neoliberal paradigm (Önder, 1998). ${ }^{43}$ Ironically, the rise in agricultural support served for easing rural political risks to allow for the implementation of the neoliberal transformation.

Increases in agricultural subsidies and significant recoveries in the agriculture sector's domestic terms of trade occurred in the 1990s, aimed to obtain rural votes and keeping rural problems within bounds. Total support in relation to GDP is estimated to have risen from $3.53 \%$ in 1986 to $3.98 \%$ in 1989 and $5.99 \%$ in 1999 (the OECD, 2018). If 1968 is taken as a benchmark 100, agriculture's domestic terms of trade were 131 in 1978, 70 in 1988 but126.3 in 1998 (Boratav, 2009). Did Turkey deviate from the neoliberal path? Önder (1998) highlights that the essence of the neoliberal transformation was concerned about the transformation of the state itself rather than about whether the levels of agricultural interventions were increased. The organisational and legal structure and functions of the state were continued to be altered in line with the premises of the neoliberal paradigm, i.e. deregulation and liberalisation. Thus, the state did not depart from neoliberalism by increasing agricultural subsidies, which in fact worked to avoid adverse political results of rural poverty and social exclusion (Buğra, 2008, pp. 201-202). Moreover, increased

\footnotetext{
${ }^{42}$ Both agricultural support and social expenditures were increased in the 1990 s to alleviate poverty and reduce the political risks of neoliberal policies. For example, the percentage of public social expenditures in Turkey's GDP increased from \% 5.53 in 1990 to \% 9.7 in 2000, a percentage similar to many OECD countries (OECD, 2016b).

${ }^{43}$ Even though a social democratic party came to power as part of the coalition government, it could not enforce a change in the economy from neoliberal transformation to one that favoured workers and agricultural producers. This was nearly a universal phenomenon: left-wing parties were undergoing an ideology crisis following the collapse of the Soviet Union in 1991, and this opened the way for disorganisation and depoliticisation of the people (Kucukaydin, 2013, pp. 70-71). Centre-left parties, which are politically adaptive to the military-bureaucracy of Turkey, actually functioned as a tool to justify neoliberalism, and their social policies could not go beyond welfare policies recommended by the IMF and the WB.
} 
agricultural subsidies and agriculture's domestic terms of trade apparently created positive incentives for agricultural producers. The average growth rate of agriculture under the aggressive neoliberal Ozal's government between 1980 and 1991 was $1.06 \%$ but between 1992 and 2000 it stood at $1.83 \%$.

The neoliberal agricultural transformation was still ongoing in the 1990s. After the 1994 economic crisis, the IMF called for the usual measures to be implemented in agriculture in return of financial assistance. Disinflationary restrictions were put on agricultural subsidies and support prices, and on financing state agricultural enterprises and agricultural cooperatives in the following years; reductions in interest rates as offered by the Agriculture Bank on loans were not allowed any longer (the IMF, 1998). Affected by internal economic problems and economic crises in Asia and Russia, Turkey signed another stand-by programme in December, 1999, and promised to implement serious structural reforms in agriculture (the IMF, 1999).

The privatisation of agricultural state enterprises was also part of the liberalisation programme. The state had already relinquished part of its monopoly rights over the tobacco market by allowing the import of tobacco in 1988 and allowed multinational tobacco companies to enter and produce for the national tobacco market in 1991 (Oral, 2015b, p. 300). After the mid-1990s, state-controlled companies which had been established for fostering the diary sector, such as the Feed Industries and the Meat and Fish Cooperation, the Milk Industries Foundation, were also privatised. Consequently the diary market was, over time, turned into an oligopolistic one instead of a market involving small and medium-scale enterprises (M. Öztürk, 2012, p. 91).

Trade liberalisation and foreign investments in agriculture and agro-industry were advanced even further in the 1990s. A dramatic decline in the production of livestock and animal products (i.e. meat, cheese, butter, ice cream) continued because of increased imports, which had started in 1984 when tariffs on food imports had been lowered (Keyder \& Yenal, 2014, pp. 115-116). The General Agreement on Tariffs and Trade (GATT) and the Customs Union with the EU also caused an agricultural trade deficit (Ay \& Yapar, 2005). Turkey's development, according to market liberalism, would have been achieved by increasing export, but imports increased, even in agriculture which had a trade surplus before. The liberalisation also helped foreign investors to increase their market share and even obtain oligopolistic positions in the national food market. To reduce risks and obtain profits from their intellectual property and franchise rights, multinational companies got more involved in 
partnerships with domestic companies of the secular bourgeoisie in western Turkey and/or took over their firms to produce, pack and sell wide range of food items (Keyder \& Yenal, 2014, pp. 117-134). Note that local, small-scale enterprises had a greater hold over the national food markets before 1980, unlike their counterparts in Latin American countries (Keyder \& Yenal, 2014, p. 112).

Let us finally outline how power distribution in the central coalition took place in the 1990s. The alliance between the secular, western Anatolian bourgeoisie and the military-bureaucracy gradually weakened in the 1990s, mainly because of the economy increasingly becoming integrated into global capitalism. This made the bourgeoisie act more independently from the state (Beris, 2008). Moreover, the enormous cost of the armed conflict against the PKK (Mutlu, 2011) ${ }^{44}$ gave rise to dissatisfaction among the capitalist classes, pointed at the military-bureaucracy. The conflicting interests between the two helped the Islamic bourgeoisie to strengthen its political-economic power in the 1990s, obtaining the support of the people in the periphery who objected to the secular mindset of the army officials (Beris, 2008). ${ }^{45}$

\subsection{The Agricultural Reform Implementation Project}

This section discusses agricultural policies implemented in the ARIP and post-ARIP period. Such periodisation does not refer to any diversion from the neoliberal agricultural transformation but the re-configuration of agricultural policies to avoid negative economic and political impacts.

Figure 4.1 explains the difference between the two periods. The figure simplifies the different political-economic regimes of agriculture with regards to varying levels of state interventions. The more a country moves away from the centre, the more the level of state interventions increases. For example, A denotes the agricultural regime of the US, while D denotes the agricultural regime of the Soviet Union. Twentieth century history has taught us that transition to another circle requires a change in the prevailing political-economic paradigm in that country, frequently coinciding with a serious change in the international power structure (i.e. the Great Depression, the emergence of the Third World and the collapse of socialism).

\footnotetext{
44 Mutlu's study (2011) shows that the total economic cost of the war was around 200-225 billion Turkish liras between 1984 and 2005 .

45 Some economic factors helped the Islamic bourgeoisie to improve its position in the political-economic rivalry, such as growing trade with the Middle East, developing economic relationships with Islamic finance from Gulf countries, and the capital accumulation based on tenders granted by the municipalities that were gained by the Islamist WP after the 1994 local elections (Savran, 2015, pp. 61-63).
} 


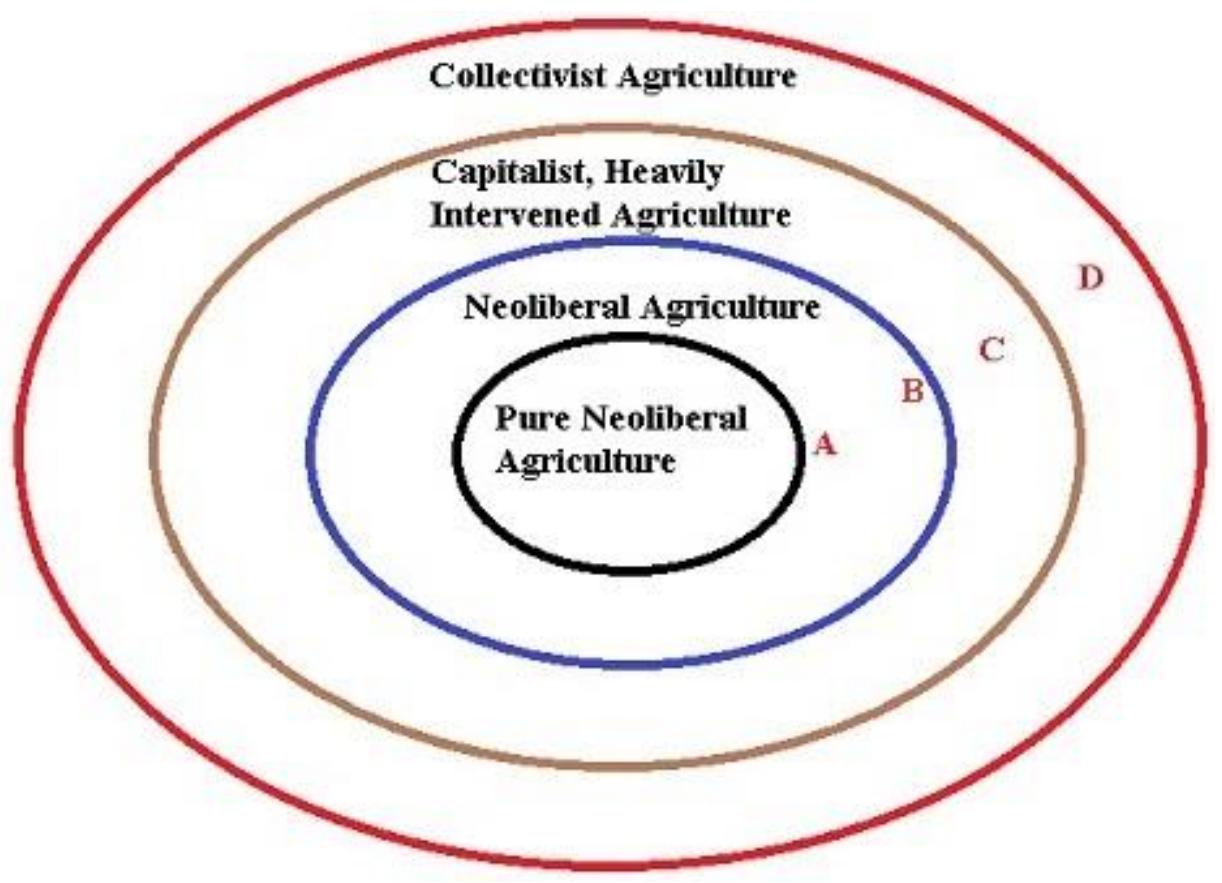

Figure 4.1 Different Political-Economic Regimes Applied to the Agricultural Sector

The centre of the figure represents a pure neoliberal regime, in which every matter of agriculture is utterly left to market dynamics with no state interventions. The regime of pure neoliberalism in agriculture remains theoretical as agricultural commodity markets have unique qualities. For one, demand for most agricultural commodities is inelastic, that is, increases in their amount for any reasons (due to for instance an increase in productivity, favourable weather conditions) will not result in large increases in demand/consumption but depressing prices, resulting in revenue loss for agricultural producers. Given that the replacement of a crop with ones with higher prices is often difficult because of factor-specific conditions (i.e. climate, soil type, geography), an individual agricultural producer, who lacks sufficient market power for setting crop prices in global markets, will try to increase the amount of the crop to cover his revenue loss. When all the producers act similarly, oversupply will occur and cause an additional fall in the crop price, and financially vulnerable agricultural producers will consequently go out of business (Bosso, 2017, pp. 2021). Again, changes in supply, especially food shortages, may cause wide range of fluctuations in prices and resultant civil strife (Bosso, 2017, p. 22). To avoid such political impacts, governments endeavour to secure the populations' access to food by intervening in agriculture, and therefore, pure neoliberalism in agriculture is unlikely.

In the developmentalist era, countries (denoted as C) intervened heavily in agriculture to divert agricultural surpluses to the industry. The costs of this policy resulted in budget deficits and distortions in the economy, creating disincentives especially for petty agricultural 
production. Today, most countries have neoliberal agricultural regimes. Developing countries are generally positioned at any point close to B in the figure but most developed countries to A. The difference between the ARIP-period and the post-ARIP period should be understood as a swing from $\mathrm{A}$ to $\mathrm{B}$.

In the ARIP-period, production-required subsidies and subsidised purchase prices were phased out in favour of the direct support payment (DIS), thus moving closer to pure neoliberalism. In the post-ARIP period, revoking the DIS, Turkey gave more importance to subsidies encouraging production, but has still continued along the path of neoliberalism. The positive effects of subsidies encouraging production and the adverse impacts of the insufficient level of agricultural support due to commitments to neoliberalism are things that will be emphasized throughout this study.

The Content of the Project: In December 1999, Turkey signed a 3-year standby programme with the IMF, which was aimed at restoring fiscal balance for solvency and reducing the inflation rate. The programme included typical neoliberal structural reforms in agriculture, to eliminate all distortions resulting from interventions and to gradually replace indirect support with the DIS. As projected, the reforms would be in transition during 2000 through a pilot programme, but fully implemented in 2001 on the national level (the IMF, 1999).

In December 1999, another important political event occurred; Turkey's candidacy for full membership of the EU was accepted. The gradual adoption of the EU Common Agricultural Policy (the EU-CAP) would impel Turkey to adhere more strictly to neoliberal reforms in agriculture. Given the existing commitments to the GATT and the World Trade Organisation - which call for measures to liberalise trade, to gradually phase out production subsidies and to lessen export subsidies, as well as the structural conditionality ${ }^{46}$ towards agriculture framed by the IMF and the WB - this matched well with the EU-CAP (Aydin, 2005, p. 161).

\footnotetext{
46 The structural conditionality aims at utilising the IMF's financial resources in accord with purposes and provisions determined by employing specific tools, such as performance criteria, prior actions, and indicative targets and benchmark (the IMF, 2001, p. 5).
} 


\begin{tabular}{|l|l|}
\hline \multicolumn{2}{|c|}{ The Policy Imple me ntations of the ARIP } \\
\hline $\begin{array}{l}\text { The Introduction of the Direct Income Support to Replace } \\
\text { Agricultural Subsidies }\end{array}$ & $\begin{array}{l}\text { The Introduction of National Farmer Registry and the } \\
\text { Completion of Land Registry and Cadastre }\end{array}$ \\
\hline $\begin{array}{l}\text { The Partial or Complete Privatisation of State Agricultural } \\
\text { Monopolies }\end{array}$ & $\begin{array}{l}\text { The Implementation of the Alternative Crop Program to } \\
\text { Lessen Oversupply of Tobacco and Hazelnuts }\end{array}$ \\
\hline $\begin{array}{l}\text { The Adjustment of Crop Prices in Subsidised Purchases to } \\
\text { International Market Prices }\end{array}$ & $\begin{array}{l}\text { The Transformation of Agricultural Sales Cooperative } \\
\text { Unions into Retrenching Autonomous Cooperatives }\end{array}$ \\
\hline $\begin{array}{l}\text { The Withdrawal of Subsidised Credits Offered by } \\
\text { Agricultural Credit Cooperatives with the Financial Support } \\
\text { of the Agriculture Bank }\end{array}$ & \\
\hline
\end{tabular}

Table 4.4 The ARIP's Policy Implementations (The World Bank, 2001a)

The Nationalist Movement Party (NMP) in the coalition government objected to contractions in agricultural supports fearing that it would lose many of its rural votes (Arpac \& Bird, 2009). But the 2001 economic crisis ended any opposition against structural reforms among the coalition government parties. Kemal Dervis from the WB was assigned to determine and coordinate macroeconomic policies, and the ARIP (see Table 4.4) was initiated in 2001. The programme was expected to reduce market-distorting agricultural economic interventions and to foster productivity in agriculture by letting AEs make their decisions under market dynamics. As Aydin (2005, p. 162) nonetheless states, Turkey was 'pushed by the IFI [international finance institutions] to sacrifice its agriculture in order to receive additional financial resources to combat its recent fiscal crisis'. Whether the ARIP produced positive results will be discussed hereafter.

\section{The Effects of the Implementation of Neoliberal Policies in the ARIP Period and the}

Post-ARIP Period : The ARIP was in effect between 2001 and 2008, and 'the so-called aim for ARIP was to eliminate inefficiencies in agriculture by "getting the prices right" while increasing the fiscal soundness of the government budget through eliminating subsidies, a typical neoliberal recipe' Unal (2012, p. 153).

The main aim of the DIS, a substantial element of the programme, was to create a neutral scheme in which agricultural producers were entitled to support payments whether they would produce or not so that agricultural markets would not be distorted (Togan, Bayener, \& Nash, 2005, p. 48). It however created disincentives to agricultural production, and hence the 
amount of cultivated land gradually declined (M. Öztürk, 2012, p. 97) ${ }^{47}$ between 2000 and 2008 by 7\%, accounting for 1.87 million hectares (ha) (Turkish Statistical Institute, 2018a). Eraktan, Abay, Miran, and Olhan (2004, p. 61) argue that on average DIS payments generated agricultural value-added $2 \%$ less than what would have been generated if production-required support payments had been granted to agricultural producers. They also assert that the DIS payments did not significantly make agricultural producers better off (p.65), not change the types of crops cultivated (pp.73-74) or improve the use of inputs (pp. 75-76). Overall, it tended to benefit LAEs and MAEs more than SAEs (Eraktan et al., 2004, p. 69). The DIS was not suitable for selectively stimulating agricultural activities, and for political bargaining on agricultural support between farmers, farmer associations and the government (The World Bank, 2009, p. 10). According to Mehdi Eker, the former Minister responsible for agricultural policies, the IMF and the WB required Turkey to apply the DIS in return for receiving credits for stabilising the economy, and the DIS did not help the country to foster crop productivity, quality and standard in agriculture (Eker, 2015, pp. 87-88). This support payment remained unpopular in the eyes of most of the stakeholders in agriculture, and its implementation was ceased after 2008.

The post-ARIP period started in 2009, but its institutional basis was established with the introduction of the Agriculture Act in 2006, a legal and policy framework to re-structure agriculture (Eker, 2015, p. 39). The ARIP mainly involved policies aimed at correcting distortions and introduce neoliberal institutional measures. The Act, however, was a commitment to development - as defined by international development organisations - such as good governance, transparency and participation in agricultural policymaking and policy practices. Defining the new support regime as a hybrid regime, Güven (2009) argues that the shift from the ARIP is 'a compromise between the continued political charm of populist corporatism and the global drive toward better targeted subsidies.' However, it is difficult to approve his argument. The main premise that market dynamics are key to the agricultural transformation has not changed in the post-ARIP period. Maintaining their commitment to neoliberalism, the government just endeavoured to adapt agricultural production to market demand conditions in terms of quality, competitiveness, productivity, and diversification of products. To this end, agricultural support has been used as "a reward" during the post-ARIP

\footnotetext{
${ }^{47}$ I was told several times during the fieldwork that some large landholders in the SAR received the payment but did not use it for producing crops. I was also shown a property in Diyarbakir, where a large landholder had constructed a mansion-like house with a swimming pool near his agricultural land allegedly paid with DIS payments. Agricultural enterprises were not required to submit any official evidence to show whether they had cultivated the land or not as the DIS payment was paid subject to owning agricultural land.
} 
period instead of a welfare transfer mechanism, to help AEs align their production to market demand conditions (Keyder, 2014, p. 215).

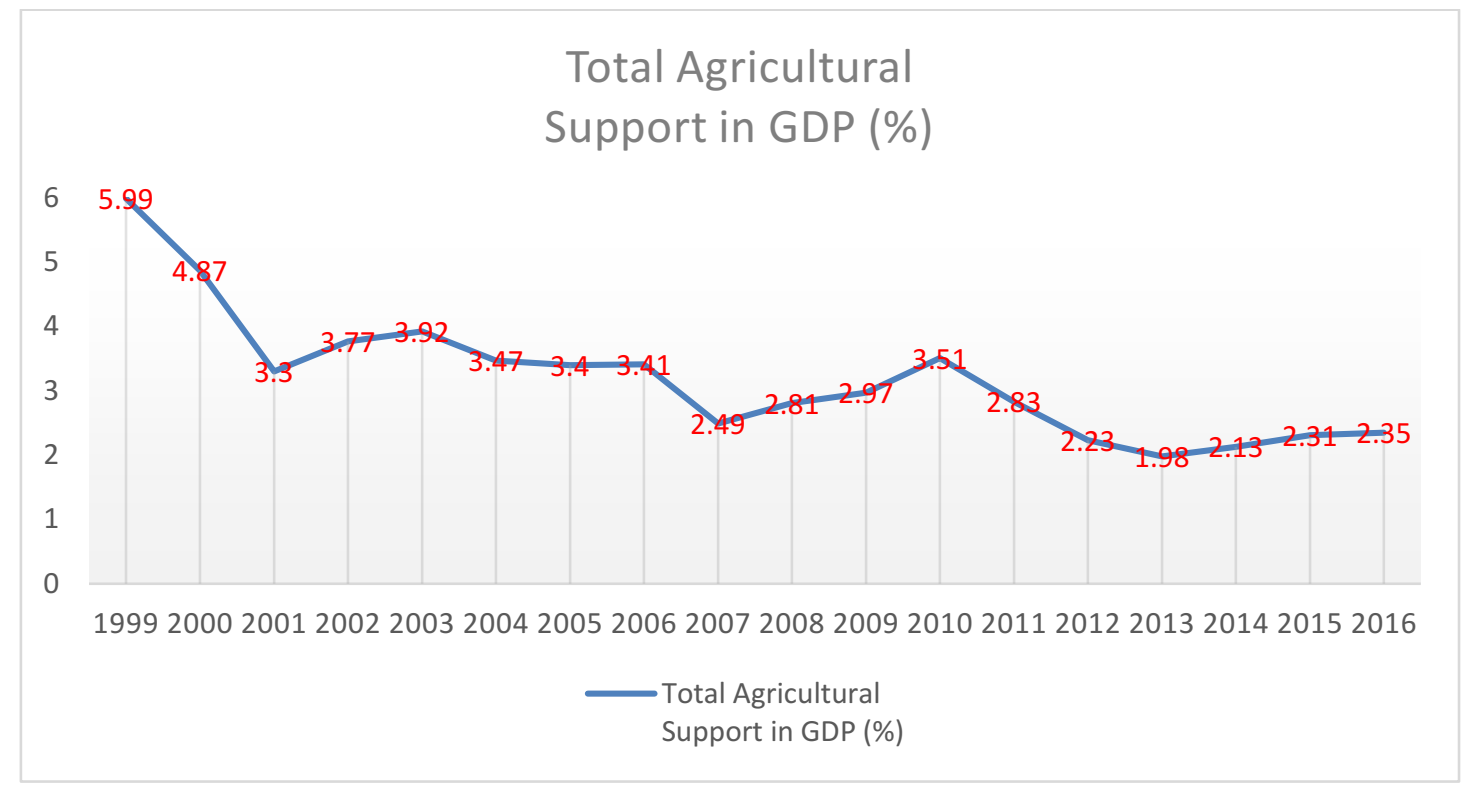

Figure 4.2 Agricultural Support in relation to Turkey's GDP (the OECD, 2018)

The changing agricultural support policy does not imply that Turkey deviated from neoliberal policies as Güven (2009) claims. The share of total agricultural support payments in GDP has decreased as seen in Figure 4.2. When the IMF programme ended, it had been dropped from $3.3 \%$ to $2.81 \%$, falling further in the-post-ARIP to $1.98 \%$ in 2013 (the OECD, 2018).

Considered by the Organisation for Economic Co-operation and Development (OECD) as a diversion from the ARIP's market-oriented aims (the OECD, 2011, p. 11), the abandonment of production-not-required subsidies and the augmentation of various production-required subsidies nevertheless came to the fore in the post-ARIP period. Two types of subsidies have especially prevailed: diesel and fertilizer support, and deficiency payments. The former is as a cash payment per decare. In addition, the certified seed support and the area-based soil analysis support are given to farmers to foster crop productivity and standardisation. Figure 4.3 shows that agricultural production has been less supported in the period of 2001-2016 compared with the year 1999 through different forms of production-based subsidies. 


\section{Chart Title}

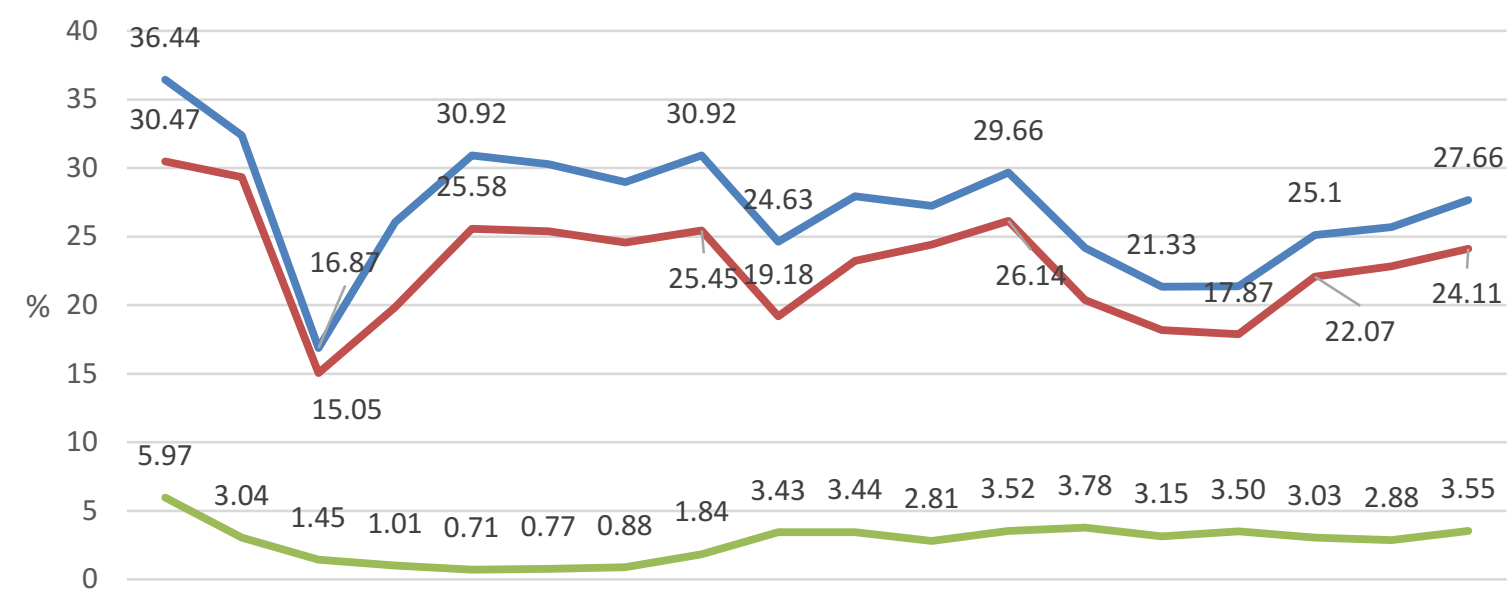

199920002001200220032004200520062007200820092010201120122013201420152016

Year

Producer Support

as a Share of Total Agricultural Production

Support Based on Commodity Output as Share of Total Agricultural Production

Input Subsidies as a Share of Total Agricultural Production

Figure 4.3 Shares of Different Support Types in Total Agricultural Production (The Organisation for Economic Co-operation and Development, 2018)

Deficiency payments or the so-called premium payment have been administered to AEs in the form of a lump sum for every production period, with the intention of increasing supplies of the agricultural products that are found insufficient to meet the national consumption (the OECD, 2011, p. 48). In order to make the premium payment an efficient tool, "the Production and Support Model for Agricultural Basins" was introduced in 2010. This dynamic, information technology-supported system was based on market-based economic, ecological and social data to render agricultural production planning appropriate for the EU's agricultural implementations ("Tarım Havzaları Yönetmeliği [The Regulation of Agricultural Basins]," 2010). 30 agricultural basins and 16 crop types - to be cultivated in those basins were specified, and the premium payment scheme was adjusted to this. The share of support payments on commodity output in total producer support payments dropped from $90.61 \%$ in 2000 to $76.29 \%$ in 2002 but peaked at $89.67 \%$ in 2009 (the OECD, 2018).

Table 4.5 shows Turkey's agricultural performance. Turkey applied highly interventionist policies in agriculture prior to 1980, representing point $\mathrm{C}$ in Figure 4.1, and highly liberal agricultural policies in the period of 1980-91 and 2001-2008, representing a point close to A. The figures show that Turkey's agriculture grew more in the highly interventionist 
developmentalist era, on average $3.4 \%$, than during the highly liberal policies, on average $1.1 \%$. The agricultural growth rate in the neoliberal period between 1980 and $2016(1.79 \%)$ is less than that in the developmentalist era $(3.43 \%)$ with heavily government interventions. It seems that production-required agricultural supports in the post-ARIP period stimulated the agricultural economy more than the production-non-required DIS payments in the ARIP period.

\begin{tabular}{|l|c|c|c|c|c|c|}
\hline Time Period & $1950-1960$ & $1960-80$ & $1980-91$ & $1991-2000$ & $2000-2008$ & $2008-2016$ \\
\hline $\begin{array}{l}\text { Average Agricultural } \\
\text { Growth Rate (\%) }\end{array}$ & 5.3 & 2.5 & 1.06 & 1.56 & 1.25 & 3.52 \\
\hline
\end{tabular}

Table 4.5 Turkey's Agricultural GDP Growth Rates in US Dollar (Sengul \& Saribal, 2015, p. 135; The World Bank, 2017)

Table 4.6 shows the relationship between agricultural support payment and agricultural GDP, arranged with the periodization that is determined by declining and increasing trends in Turkey's agricultural support payment growth. The table reveals that generally the higher the agricultural support payments, the higher the agricultural GDP growth rate is.

\begin{tabular}{|l|r|r|r|r|r|r|}
\hline Periods & $1998-2001$ & $2001-2006$ & $2006-2007$ & $2007-2010$ & $2010-2013$ & $2013-2015$ \\
\hline $\begin{array}{l}\text { Agricultural } \\
\text { Support Growth }\end{array}$ & $-49.67 \%$ & $67.74 \%$ & $-24.79 \%$ & $48.72 \%$ & $-30.24 \%$ & $28.45 \%$ \\
\hline $\begin{array}{l}\text { Agricultural } \\
\text { GDP Growth }\end{array}$ & $-7.47 \%$ & $21.94 \%$ & $-6.22 \%$ & $17.19 \%$ & $8.16 \%$ & $7.18 \%$ \\
\hline
\end{tabular}

Table 4.6 Turkey's Agricultural Support Growth and Agricultural GDP Growth (the OECD, 2018; Turkish Statistical Institute, 2017f)

Table 4.7 shows that the total area of cultivated land has declined by around $17 \%$ in the neoliberal period, whereas it increased by around $11.3 \%$ in the developmentalist era. Even relaxing neoliberal policies with production-based payments have slowed reductions in cultivated lands, that is, the reduction in total cultivated lands is in the post-ARIP period (3.24\%) lower than the reduction in the ARIP-period (7\%). Clearly, the neoliberal agricultural transformation has adversely affected the total area of cultivated land in Turkey. 


\begin{tabular}{|l|c|c|c|c|c|c|}
\hline Years & 1960 & 1979 & 1980 & 2001 & 2008 & 2017 \\
\hline Total Cultivated Areas (1000 hectares) & 25324 & 28625 & 28175 & 26350 & 24505 & 23385 \\
\hline Periods & \multicolumn{2}{|c|}{$1960-1980$} & $1980-2001$ & $2001-2017$ \\
\hline Change & \multicolumn{2}{|c|}{$11.26 \%$} & $-6.48 \%$ & $-11.25 \%$ \\
\hline
\end{tabular}

Table 4.7 The Total Area of Cultivated Land (Turkish Statistical Institute, 1967, 1998, 2000, 2017e)

Table 4.8 exhibits shares of AEs by size in the total land size and the total AE number between 1980 and 2006. Assuming that if AEs with land equal to or less than 100 decares are SAEs, between 100 and 500 decares are MAEs, and more than 500 decares are LAEs. Then, the proportion of SAEs declined by $4.20 \%$ whereas their land share markedly shrivelled by around $17 \%$. In contrast, the proportion of LAEs in the total AE number and their land share grew considerably (respectively \% 125 and around 75.5\%). As for MAEs, their share in the total number of AEs highly climbed (around 14.50\%) but their land share shrunk somewhat (around 4.50\%). It appears that the neoliberal agricultural transformation favoured LAEs at the expense of SAEs and some MAEs, helping LAEs add more land. Nevertheless, the number of SAEs in the total AE number has only slightly decreased though the rural population has dramatically dropped (M. Öztürk, Jongerden, \& Hilton, 2018). In fact, the former could have decreased much more because Turkey's inheritance law has a raising effect on total numbers of AEs in each category. According to Unal (2012, p. 116) the very strong inverse relationship between farm size and agricultural productivity in Turkey, may explain why the withdrawal of SAEs has slowed down. SAEs tend to utilise their lands much more intensive than LAEs through intensive use of labour, and land fragmentation has positively influenced agricultural productivity in Turkey (Unal, 2012, pp. 117, 119).

The government clearly forces AEs to become competitive in a market-oriented agriculture; yet, adaptation to technology and new types of information and methods bring financial hardships and redundant family labourers to smallholding families (M. Öztürk et al., 2018). Where non-agricultural expenditure increases but agricultural income drops because of a fall in relative prices of agricultural goods, smallholding families have followed different strategies: a) they have sold their lands and moved to urban areas, living in poverty; b) young family members have migrated to urban areas to earn money and transferred part of their 
income to their family in rural areas, which results in the aging of rural population ; c) they have stayed in the rural areas but worked in non-farm or agricultural jobs.

\begin{tabular}{|c|c|c|c|c|c|}
\hline Size (da) & Unit of Criterion & 1980 & 2001 & 2006 & $\begin{array}{c}\text { Change between } \\
\text { 1980-2006 (\%) }\end{array}$ \\
\hline \multirow{2}{*}{$0-20$} & Number (\%) & 30.2 & 33.36 & 24.8 & $-17.88 \%$ \\
\hline & Land $(\%)$ & 4.14 & 5.32 & 3.3 & $-20.29 \%$ \\
\hline \multirow{2}{*}{$20.01-50$} & Number (\%) & 31.9 & 31.46 & 32.7 & $2.51 \%$ \\
\hline & Land $(\%)$ & 15.9 & 16.02 & 12.9 & $-18.87 \%$ \\
\hline \multirow{2}{*}{$50.01-100$} & Number (\%) & 20.25 & 18.53 & 21.4 & $5.68 \%$ \\
\hline & Land $(\%)$ & 21.25 & 20.68 & 18.1 & $-14.82 \%$ \\
\hline \multirow{2}{*}{ Sub Total } & Number (\%) & 82.35 & 83.35 & 78.9 & $-4.19 \%$ \\
\hline & Land $(\%)$ & 41.29 & 42.0 & 34.3 & $-16.93 \%$ \\
\hline \multirow{2}{*}{$100.01-200$} & Number (\%) & 11.55 & 10.83 & 12.7 & $9.96 \%$ \\
\hline & Land $(\%)$ & 23.85 & 23.81 & 21.0 & $-11.95 \%$ \\
\hline \multirow{2}{*}{$200.01-500$} & Number (\%) & 5.3 & 5.1 & 6.6 & $24.53 \%$ \\
\hline & Land $(\%)$ & 22.84 & 22.82 & 23.6 & $3.33 \%$ \\
\hline \multirow{2}{*}{ Sub Total } & Number (\%) & 16.85 & 15.93 & 19.3 & $14.54 \%$ \\
\hline & Land $(\%)$ & 46.69 & 46.63 & 44.6 & $-4.48 \%$ \\
\hline \multirow{2}{*}{$500.01+$} & Number (\%) & 0.8 & 0.72 & 1.8 & $125.00 \%$ \\
\hline & Land $(\%)$ & 12.02 & 11.35 & 21.1 & $75.54 \%$ \\
\hline \multirow{2}{*}{ Total } & Number (\%) & 100 & 100 & 100 & \\
\hline & Land (\%) & 100 & 100 & 100 & \\
\hline
\end{tabular}

Table 4.8 The Percentage Distribution of Number and Land Share of AEs by Size (M. Öztürk, 2012, p. 78; Turkish Statistical Institute, 1983, 2017b)

It is clear that average agricultural GDP growth was higher in the developmentalist era than in the neoliberal period, as a result of government interventions. Moreover, Turkey was one of the countries achieving self-sufficiency in food production (Cakmak \& Yeldan, 1994, p. 225). Interventionist policies, intermingling political interests of politicians, caused economic inefficiency and resultant crises in developing countries that were exacerbated by external shocks and the global crisis of capital accumulation ${ }^{48}$. This way of policy interventions in agriculture executed by top-down decision-making turned out to be unsustainable, but brought some success in Turkey. Since the period when dramatic shifts were made to neoliberal policies that have heavily reduced the level of interventions, the evidence shows that agricultural growth rates have slowed down to its lowest level, and rural poverty has continued (Unal, 2012, pp. 12-16). Indeed, the percentage of rural poor has increased ( from 34.48 to $38.69 \%$ between 2002 and 2009) (Turkish Statistical Institute, 2017e). What matters

\footnotetext{
${ }^{48}$ According to J. O'Connor (1984, p. 56), a capital accumulation crisis occurs when the struggle between the working class and capitalist classes, the emergence of new forms of capitalist competition, the state apparatus and the dynamics of the society become barriers to advance capitalist accumulation, referring to inadequate production of the surplus value and its unproductive use after it has been generated once.
} 
is to find out how agricultural interventions can be designed and financed in order to achieve high agricultural growth but without imposing a heavy burden on the economy. Chapter 7 points out some aspects of well-designed agricultural interventions in reference to SAR's agriculture.

\subsection{The South-eastern Anatolia Development Project and Agriculture}

Below we show how the GAP has transformed over time. Note that the agricultural government interventions for this project are different from those executed at the national level. In the final section we argue that the SAR is a less developed region compared to other regions in Turkey, and describe the various characteristics of SAR's agriculture.

\subsubsection{The South-eastern Anatolia Development Project}

Turkey's regions were first defined at the First Geography Congress held in 1941, based on their geographic characteristics. Much later, the Turkish Statistical Institute defined 12 main regions and 26 sub-region for statistical purposes (see Figure 4.4).

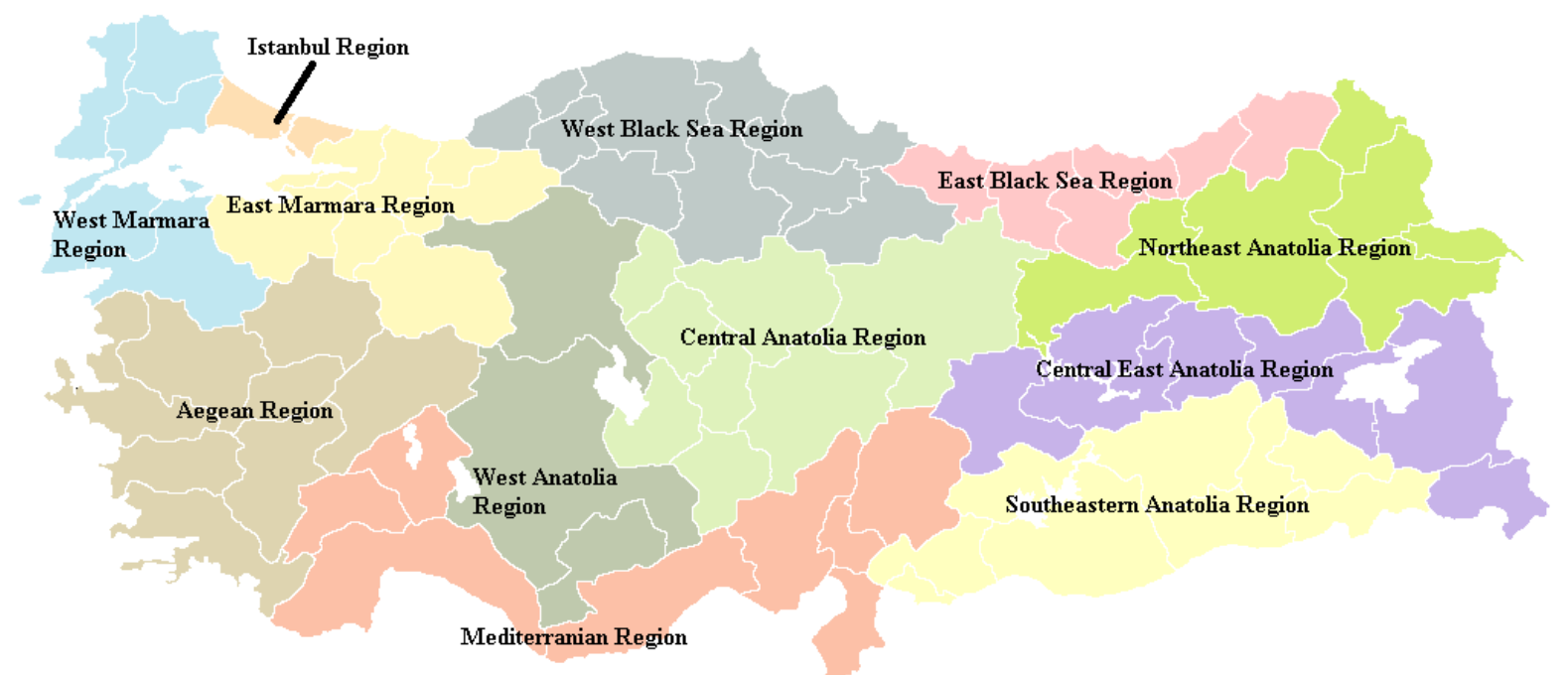

Figure 4.4 The Nomenclature of Territorial Units for Statistics- Statistical Regions of Turkey Adapted from (Civelek, 2011, under the licence of Creative Commons Attribution-Share Alike 3.0 Unported)

The SAR includes nine cities and two transboundary rivers, the Euphrates and the Tigris (see Figure 4.5). Designed at first for benefitting from these rivers, the GAP's history dates back to the early period of the Republic. The first studies collecting data for the Euphrates were conducted in 1936 and in 1945 for the Tigris, by setting up gauging stations in 1954; the studies were accelerated and ended up compiling basin-level reports. The most important project in the Upper Euphrates basin, the construction of Keban Dam, was launched in 1966 
and came into service in 1974. By 1980, the State Hydraulic Works (DSI in Turkish acronym) integrated the reports that had been prepared for the Lower and Middle Euphrates basins and for the Dicle basin into a single project, which was called the GAP (DSI, pp. 1011). In the developmentalist era, the GAP was just designed as an infrastructure project, building twenty-one dams to regulate water flows, generate electricity with seventeen hydroplants and irrigate farmlands. ${ }^{49}$ Upon completion the regional irrigation systems were supposed to irrigate about 20 per cent of Turkey's total irrigable land; hydropower plants would generate over 20 per cent of Turkey's total economically exploitable electricity potential (GAP-RDA, 2014; The State Planning Organisation, 1990, p. 18). The GAP has raised people's hopes for economic development, but at the same time caused ecological alterations and triggered a strong reaction following the destruction of Kurdish heritage, as seen in the case of Hasankeyf that will be submerged in Ilisu Dam's reservoir (Jongerden, 2010a).

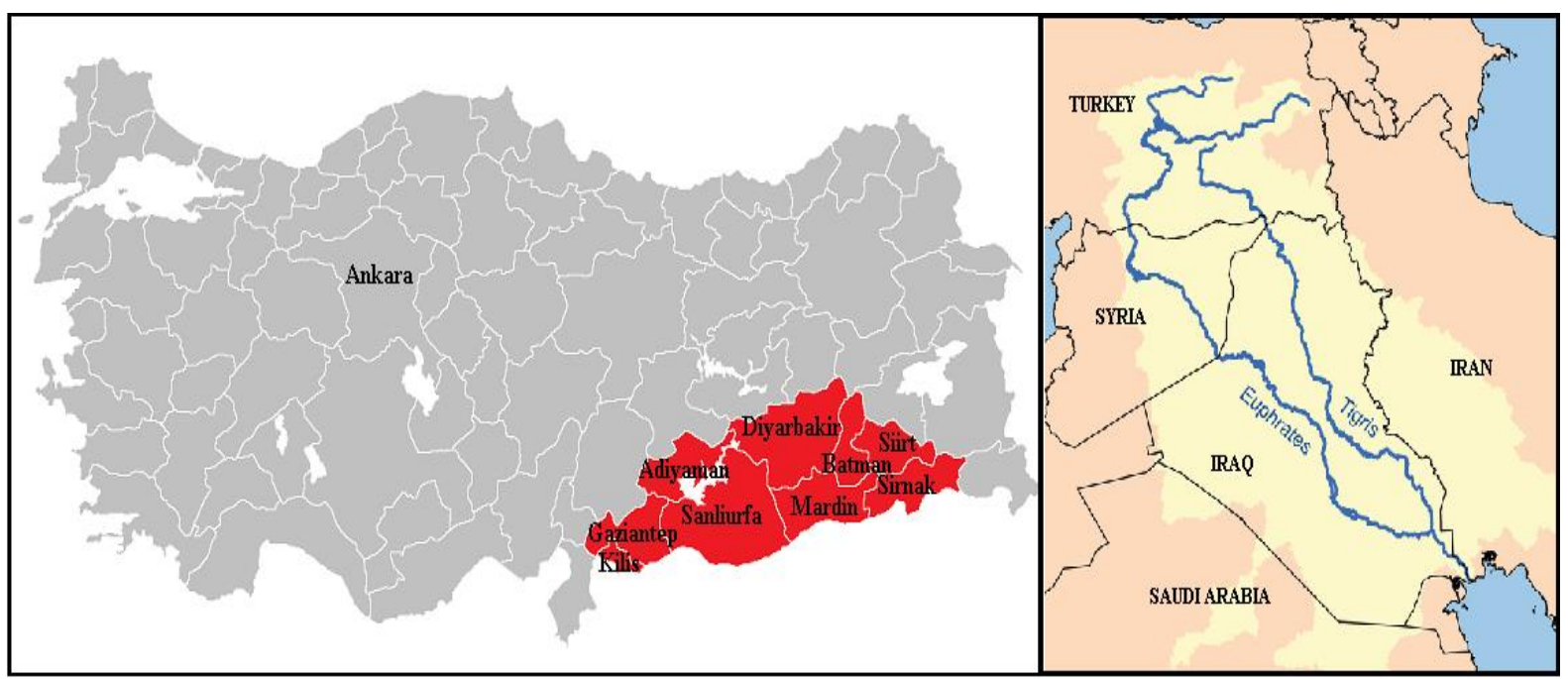

Figure 4.5 The South-eastern Anatolia Region and Its Cities, Adapted from (Baydin, 2006, Creative Commons Attribution-Share Alike 3.0 Unported; Musser, 2005, Creative Commons Attribution-Share Alike 2.5 Generic)

A major transformation in the GAP happened during the first decade of the neoliberal period. With the GAP Master Plan, introduced in 1989, it turned from an infrastructure project into a multi-sectorial, integrated economic and social development project, particularly concentrating on agriculture, industry, infrastructure and social sectors. The main reason for the transformation of the project was that the SAR was one of least developed regions in Turkey (The State Planning Organisation, 1990, p. 1). Indeed, the region's per capita income (637 US Dollar) was less than half Turkey's average (1350 US Dollar) in 1985 (Unver, 1997)

${ }^{49}$ Later updated to 22 dams and 19 hydro plants. 
and less than a third of the most developed Marmara Region (2182 US Dollar) (Turkish Statistical Institute, 2017b). The regional contribution to Turkey's GDP was low (4\%), and the prevailing economic sector was agriculture (around 40\%) (Unver, 1997).

The exacerbating armed conflict with the PKK partly induced the state to make such changes to the project, adding social objectives to the economic ones. The rationale was simple: the more the wellbeing of the people in the region improves, the lower the support for or participation in the PKK (Ozok, 2004, pp. 27-28, 36). But beyond this, the transformation of Kurds into Turks had been an ambitious aim for the state from the outset. According to Ozok (2004, pp. 39-50), the studies and surveys conducted by the GAP-RDA treated the regional population as "observable, quantifiable objects"; social programmes were implemented to control them; GAP activities were, in a sense, intended to undermine the PKK's cause.

If we leave its social objectives and scope aside, the Master Plan essentially envisaged that the SAR would became an export region based on agriculture (The State Planning Organisation, 1990, p. 5), complying with the national strategy of export-oriented industrialisation, which Turkey had adopted in 1980 along with the neoliberal mindset. The Plan specifically projected the establishment of agro-industries that could produce exportable goods from a range of industrial crops to be cultivated through irrigation. In this way, the state indicated her willingness to intervene in the regional economy, but encouraging private actors to be involved in the necessary investments (The State Planning Organisation, 1990, pp. 3-4). In this sense, the subsidisation of industrial crops, the policy of adjusted agricultural irrigation prices, the improvement in the distribution of land rights in favour of smallholders and tenant farmers, the policy of selective investments in industry, and the provision of credits and various financial incentives to farmers and industrial entrepreneurs were envisaged as the components of interventionist policies to be applied in the region (The State Planning Organisation, 1990, pp. 23-26). However, the objectives of the plan were not realised because of the armed conflict with the PKK and the intermittent financial crises which occurred in the 1990s (The GAP-RDA, 2002b, pp. 2-3), and the contribution of private actors to investments remained limited.

The completed GAP projects related to agriculture in the 1990s were the construction of Ataturk Dam and the linked irrigation systems in part of Sanliurfa. This tripled agricultural value-added per decare in 1995 when irrigation water was first provided (Unver, 1997). It should however be noted that just over 12.5 per cent of the envisaged land to benefit from irrigation water actually did so by 2002 (The GAP-RDA, 2003, p. 19). According to Isgin's 
study (2006), the average agricultural income in Sanliurfa increased 3.5 times in ten years after the Ataturk Dam first supplied irrigation water to Sanliurfa's plains; yet, the unfair distribution of land rights in the region favoured LAEs. In contrast to the commitment made in the Master Plan, the land right system did remain intact.

Another transformation of the GAP was made in the late 1990s. Having conducted a successful counter-guerrilla war during nearly a decade, the Turkish state eventually put an end to the armed conflict, capturing the PKK's leader, Abdullah Ocalan, in 1999. Once this outcome became more likely in the mid-1990s, the state moved to a post-conflict period, and to a global development mentality (Ozok, 2004, pp. 106-107), based on the Agenda 21 of the Rio Summit in 1992, which promotes a vision of sustainable development grounded in environmental sustainability, participatory governance, combatting poverty, international cooperation for capacity building in developing countries (The United Nations, 1992). The first step was to launch a programme under the supervision of the United Nations Development Programme (UNDP): the GAP would now be seeking to realise sustainable human development at the regional level ("Strengthening the Integrated Regional Development and Reduction of Socio-Economic Inequalities in the GAP Region," 18 March, 1997).

As Ozok (2004, pp. 107,109) argues, the concept of sustainable human development was disguising the neoliberal way of development underpinned by rising global capitalism, which takes 'the market [as] the major mechanism around which the economic, political and social relations' are re-structured. The role of the state in development, as the former president of the WB, Barber Conable states, should smooth the path for market actors by improving human resources, especially of the poorest; by creating a favourable environment for market actors that incorporates competitiveness, adequate infrastructure and well-functioning institutions; by integrating the national economy into the global economy, and by placing the economy on a stable macroeconomic footing (The World Bank, 1991, p. iii). Ozok (2004, pp. 110-135) however points out that development has in fact been tailored for the needs of capitalists rather than those of the poor, and presents that the social programmes of the GAP have worked in the same way by establishing a conceptual and practical link between sustainable human development and market-led development.

The GAP Development Plan 2002-2010 was the product of the participatory planning of different stakeholders, including international, national and local public organisations, universities and non-governmental organisations (The GAP-RDA, 2002c, p. 16). The Master 
Plan had rested on public investments to achieve its aims whereas the GAP Development Plan gave an important role to private actors, especially for industrial investments. The state also committed to further the market economy and invest in infrastructure and public goods, e.g. education programmes for the disadvantaged and agricultural extension, where sustainability, human development, and participation were taken as the required criteria for development within possible technical constraints (The GAP-RDA, 2002b, pp. 7,10; 2002c, pp. 20, 38-39). As for agriculture, market-oriented production supported by irrigation investments, participatory rural programmes, ecological preservation and the alleviation of poverty of the landless, marginal smallholders ${ }^{50}$ and those who had left agriculture and became the urban poor were also addressed in the plan (The GAP-RDA, 2002b, pp. 23-28). Two action plans were prepared for the period of 2008-2012 (The GAP-RDA, 2008) and for 2014-2018 (The GAP-RDA, 2014), complying with the EU's acquis for stimulating regional development through financial assistance from the union. Regional development agencies were established in 2008-2009 all across the country, and the legislative and institutional frameworks were gradually improved in line with the EU acquis underpinned by the global development mentality (Sungur, Keskin, \& Dulupçu, 2014). As a result, EU's financial assistance (the Instrument for Pre-Accession Assistance), including regional, rural and human development assistance, had amounted to around 2.5 billion euros by 2017 (Directorate for EU Affairs, 2017).

As a result of all the efforts, irrigated land in the SAR increased from 180,000 ha in 2002 to 546,000 ha in 2017 , accounting for $30 \%$ of the total planned irrigated land (The GAP-RDA, 2018, pp. 29-30). The total vegetative production of Turkey and the SAR in nominal values and at current US dollar rates had accrued by around 118\% and around 209\% respectively between 1994 and 2016. The SAR, in this sense, outperformed the most developed regions in the west Turkey, the Aegean Region (nearly 82\%) and the Western Marmara region (around 84\%) (Turkish Statistical Institute, 1994, 2018a). The total export of the SAR, mostly agroproducts, increased by 16 times between 2000 and 2017, far more than Turkey's average (4.6 times) (The GAP-RDA, 2018, p. 38). As Table 4.9 illustrates, the SAR increased per capita income more than Turkey's average between 1985 and 2016 but is still lower. The SAR is still economically one of the relatively less developed regions in Turkey. Western Anatolia, in comparison has a per capita income of 7876 US Dollar (The GAP-RDA, 2018, p. 16).

\footnotetext{
${ }^{50}$ Marginal smallholders are those who have land areas that are too small so that they cannot yield the required level of income to save oneself from poverty, even with the adoption of improved technology.
} 


\begin{tabular}{|l|c|c|c|c|}
\hline Regions & 1985 & 1998 & 2016 & $\begin{array}{c}\text { Change Between } \\
1985-2016\end{array}$ \\
\hline The SAR & 637 & 1685 & 3256 & $411 \%$ \\
\hline Turkey & 1350 & 3243.5 & 6337 & $369 \%$ \\
\hline
\end{tabular}

Table 4.9 The Comparison between the SAR and Turkey in Terms of Per Capita Income (The GAP-RDA, 2018, p. 16)

\subsubsection{The South-eastern Anatolia Region and Agriculture}

The SAR is a relatively less development region in Turkey. The per capita income of the SAR is just over half of Turkey's average. Its poverty level ${ }^{51}$ (28.8 \% in 2017) is higher than Turkey's average (20.5\%), and just over $26 \%$ of Turkey's poor reside in the SAR (Turkish Statistical Institute, 2017b) though the SAR's population is just over one-tenth of the total population. In terms of the human development index value, an indicator of the average quality of health, education and material life of the people, 7 out of the 9 cities in the region were among the 20 cities with the lowest rankings in 2000 (The UNDP, 2004, pp. 63-65). In terms of the socio-economic development value, the same cities are ranked among 15 cities with the lowest values in 2010; all of SAR's cities had seemingly regressed from 1996 to 2010 except for Batman, Sirnak and Siirt (Baday Yildiz, Sivri, \& Berber, 2012).

\begin{tabular}{|l|c|c|c|c|c|c|}
\hline Cities & $\begin{array}{c}\text { Agriculture/ } \\
\text { Provincial GDP }\end{array}$ & $\begin{array}{c}\text { Industry/ } \\
\text { Provincial GDP }\end{array}$ & $\begin{array}{c}\text { Services/ } \\
\text { Provincial GDP }\end{array}$ & $\begin{array}{c}\text { Agriculture/ } \\
\text { Regional } \\
\text { Sectorial GDP }\end{array}$ & $\begin{array}{c}\text { Industry/ } \\
\text { Regional } \\
\text { Sectorial GDP }\end{array}$ & $\begin{array}{c}\text { Services/ } \\
\text { Regional } \\
\text { Sectorial GDP }\end{array}$ \\
\hline Gaziantep & $4.03 \%$ & $41.52 \%$ & $42.90 \%$ & $10.83 \%$ & $47.79 \%$ & $27.90 \%$ \\
\hline Adryaman & $12.65 \%$ & $30.39 \%$ & $45.40 \%$ & $7.84 \%$ & $8.07 \%$ & $6.82 \%$ \\
\hline Kilis & $20.94 \%$ & $15.19 \%$ & $52.32 \%$ & $2.82 \%$ & $0.88 \%$ & $1.70 \%$ \\
\hline Şanliurfa & $23.39 \%$ & $19.42 \%$ & $45.63 \%$ & $31.93 \%$ & $11.36 \%$ & $15.08 \%$ \\
\hline Diyarbakır & $12.39 \%$ & $22.79 \%$ & $53.26 \%$ & $19.70 \%$ & $15.52 \%$ & $20.50 \%$ \\
\hline Mardin & $17.75 \%$ & $14.83 \%$ & $55.86 \%$ & $14.16 \%$ & $5.07 \%$ & $10.80 \%$ \\
\hline Batman & $10.82 \%$ & $29.32 \%$ & $48.30 \%$ & $5.40 \%$ & $6.27 \%$ & $5.84 \%$ \\
\hline Şrnak & $6.33 \%$ & $13.00 \%$ & $69.11 \%$ & $2.85 \%$ & $2.51 \%$ & $7.53 \%$ \\
\hline Siirt & $15.07 \%$ & $19.98 \%$ & $53.40 \%$ & $4.46 \%$ & $2.54 \%$ & $3.83 \%$ \\
\hline The SAR & $11.85 \%$ & $27.66 \%$ & $48.94 \%$ & $100.00 \%$ & $100.00 \%$ & $100.00 \%$ \\
\hline Turkey & $6.59 \%$ & $28.20 \%$ & $53.66 \%$ & $6.59 \%$ & $28.20 \%$ & $53.66 \%$ \\
\hline
\end{tabular}

Table 4.10 The Sectorial Shares of Each City in the SAR in 2017 (Turkish Statistical Institute, 2018a)

There is a relation between lack of development, poverty and the prevalence of agriculture. The shares of agriculture and industry in GDP are around $11.85 \%$ and $27.70 \%$ respectively

\footnotetext{
${ }^{51}$ The figure shows the regional share of the poor by poverty threshold, 60 per cent of Turkey's median income adjusted by purchase power parity.
} 
for the SAR but around 6.60\% and 28.20\% for Turkey (Turkish Statistical Institute, 2018a). ${ }^{52}$ However, as displayed in Table 4.10, there is an uneven development in the SAR. Gaziantep's industrial GDP accounts for $48 \%$ of the total regional industrial GDP. Though Sanliurfa and Diyarbakir have large agricultural land (see Table 4.11), half of the industrial firms in the region (mostly textile and agro-food firms) are conglomerated in Gaziantep (The GAPRDA, 2012, p. 46). The distribution of agricultural land is uneven among the cities as seen in Table 4.11. Batman, Sirnak and Siirt lack wide flat agricultural land because of topographical conditions characterised by isolated hills and mountains.

\begin{tabular}{|l|c|}
\hline Cities & $\begin{array}{c}\text { Their Share in Total } \\
\text { Regional Agriculural Lands }\end{array}$ \\
\hline Gaziantep & $11.85 \%$ \\
\hline Adryaman & $7.91 \%$ \\
\hline Kilis & $3.46 \%$ \\
\hline Şanliurfa & $37.35 \%$ \\
\hline Diyarbakır & $19.39 \%$ \\
\hline Mardin & $10.55 \%$ \\
\hline Batman & $3.07 \%$ \\
\hline Şırnak & $3.60 \%$ \\
\hline Siirt & $2.82 \%$ \\
\hline
\end{tabular}

Table 4.11 The Distribution of Agricultural Lands Among the SAR's Cities (Turkish Statistical Institute, 2017b)

In 1985, agricultural employment accounted for around $71 \%$ of total regional employment but this decreased to $25 \%$ in 2017 , still more than Turkey's average (19.4\%) (The State Planning Organisation, 1989, p. 111; Turkish Statistical Institute, 2018a). This has happened not just because of economic development policies but also due to diminishing returns as a result of population growth as well as due to the forced displacement carried out by the state and the insecure rural milieu during the armed conflict. The influx of rural people into urban areas has swelled the urban service sector, which provides low-paid insecure jobs. The figures of the last five cities (the east SAR cities) in the table that suffered from the armed conflict at the highest level give ample evidence for the swelling service sector. ${ }^{53}$ After all, the ruralisation rate is still high, around $30.40 \%$, implying an urbanisation rate of $69.60 \%$. It means that the region falls behind the West Anatolia Region (90.6\%) and the East Marmara Region $(85.12 \%)$ in terms of urbanisation rate (Turkish Statistical Institute, 2017d). As

\footnotetext{
52 When we exclude Istanbul's GDP from the national GDP, the share of agriculture in the national GDP increases to around $9.40 \%$.

${ }^{53}$ Given the share of industry in Batman's GDP, the city cannot be considered as a distinct case as it is based on petroleum industry. If that industry did not exist, Batman would be similar to other East SAR cities.
} 
illustrated in Table 4.12, the urbanisation rate substantially varies among the cities of the region. In addition, given that agro-industry is prevailing in the region, agriculture is of importance for earning livelihood and sustaining and fostering economic development.

\begin{tabular}{|c|c|c|c|c|c|c|c|c|c|}
\hline & \multicolumn{4}{|c|}{ The West SAR } & \multicolumn{5}{c|}{ The East SAR } \\
\hline & Gaziantep & Kilis & Adiyaman & Sanliurfa & Diyarbakir & Mardin & Batman & Sirnak & Siirt \\
\hline Urbanisation rate & $89.18 \%$ & $71.54 \%$ & $61.38 \%$ & $55.36 \%$ & $72.56 \%$ & $59.26 \%$ & $74.70 \%$ & $64.01 \%$ & $61.66 \%$ \\
\hline Ruralisation rate & $10.82 \%$ & $28.46 \%$ & $38.62 \%$ & $44.64 \%$ & $27.44 \%$ & $40.74 \%$ & $25.30 \%$ & $35.99 \%$ & $38.34 \%$ \\
\hline
\end{tabular}

Table 4.12 Urbanisation and Ruralisation Rates of SAR's Cities in 2012 (Turkish Statistical Institute, 2018a)

Figure 4.6 shows the distribution of agricultural land in the SAR as to their utilisation in the mid-1980s as well as the agricultural land to be irrigated according to the Master Plan. As over thirty years have passed, the figure probably does not fully reflect the current land utilisation. For example, a certain amount of agricultural land that was close to main stream or tributaries of the Euphrates and Tigris must not be seen in the figure as they submerged following the construction of dams and reservoirs. Again, some agricultural land has been left idle for years as their owners abandoned them or were forced to abandon their villages during the armed conflict, which mostly occurred in the right side of the red line, denoting the administrative boundary between the west SAR's and the east SAR's cities.

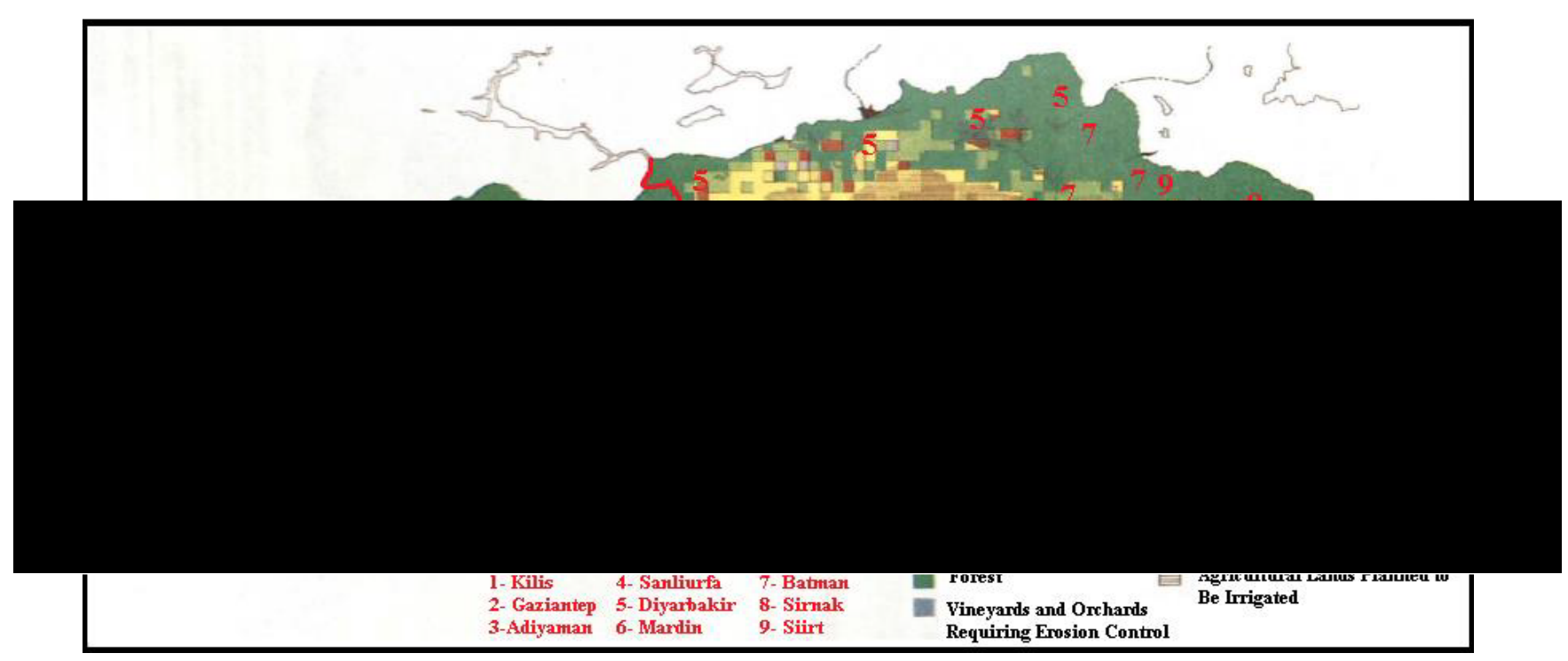

Figure 4.6 The Use of Lands in the South-eastern Anatolia Region in the mid-1980's Adapted from The State Planning Organisation (1990, p. 15) 
Although academic material and statistics showing the effects of the armed conflict on the SAR's agriculture are limited and/or absence, Table 4.13 shows that the east SAR was severely affected by the armed conflict, and in particular by the counter-guerrilla strategy of the state. It is clear that the forced village evacuations imposed by the state, often followed by their subsequent destruction and the insecure environment heavily hit the east SAR's agriculture. Croplands, orchards, vineyards, trees, hives, livestock, harvested crops, barns and houses were destroyed in the fight between the PKK and the security forces (KHRP, 2002, pp. 69-72; TGNA Inquiry Commission, 1998, pp. 21-22). The use of agricultural land, pastures and plateaus remained limited because of the landmines placed along the PKK militants' routes to Turkey or in rural areas or towns (TGNA Inquiry Commission, 1998, pp. 50-51). Furthermore, state officials prohibited the use of pasture and plateaus in some cases, which adversely affected livestock farming (Human Rights Watch/Helsinki, 1993, p. 9). Staple and cash crops being grown were also uprooted by village guards and security officials (Human Rights Watch, 2005, p. 30) to compel villagers to leave the contested rural areas, thus impairing the PKK's logistic capabilities (TGNA Inquiry Commission, 1998, p. 22). Consequently, agricultural production in tons fell by nearly $14 \%$ in the east SAR while it rose by around 9 in the west SAR and by around $13.50 \%$ in the entire country when the counterguerrilla war of the Turkish state against the PKK started (Turkish Statistical Institute, 1989, 1999).

\begin{tabular}{|l|c|c|c|}
\hline $\begin{array}{c}\text { Total Amount of Cultivated Areas Including Fields, } \\
\text { Vegetable Orchards and Vineyards (ha) }\end{array}$ & Change \\
\hline Regions/Years & 1989 & 1999 & $1989-1999$ \\
\hline The West SAR & $1,605,529$ & $1,633,423$ & $1.74 \%$ \\
\hline The East SAR & $1,362,020$ & $1,295,965$ & $-4.85 \%$ \\
\hline The SAR & $2,967,549$ & $2,929,388$ & $-1.29 \%$ \\
\hline Turkey & $25,477,000$ & $24,814,000$ & $-2.60 \%$ \\
\hline \multicolumn{4}{|c|}{} \\
\hline \multicolumn{4}{|c|}{ Total Number of Trees in Fruit Orchards } \\
\hline Regions/Years & 1989 & 1999 & $1989-1999$ \\
\hline The West SAR & $35,539,208$ & $41,189,749$ & $15.90 \%$ \\
\hline The East SAR & $5,325,885$ & $4,786,037$ & $-10.14 \%$ \\
\hline The SAR & $40,865,093$ & $45,975,786$ & $12.51 \%$ \\
\hline Turkey & $554,300,000$ & $572,565,000$ & $3.30 \%$ \\
\hline
\end{tabular}

Table 4.13 Changes in the Total Cultivated Lands in the SAR between 1989 and 1999 (Turkish Statistical Institute, 1989, 1995, 1999)

Where the regional agricultural market was immature, the destruction of agricultural production structure compounded rural life conditions and necessarily frustrated the 
development of a market economy. The neoliberal agricultural transformation started in 1980 had already forced a large group of SAEs in the SAR to produce at or below subsistence level following the minimization of government interventions in economic activities (P. J. White, 1999). These drops in subsidised purchases and other subsidies deeply impacted the SAR's agriculture (Yukseker, 2009, p. 266 cited by Keyder \& Yenal, p.162). Furthermore, those who produced export cash crops such as tobacco and cotton were deeply affected by the devaluation in Turkish lira (Boratav, 1990, pp. 212-215). During the armed conflict, the agricultural production base of the east SAR was further destroyed. The result was the disintegration of the traditional peasantry ${ }^{54}$, referring to subsistence farming, and subsequently market orientation could be extended into the entire rural area of the region at the start of the ARIP (Keyder \& Yenal, 2014, pp. 161-162).

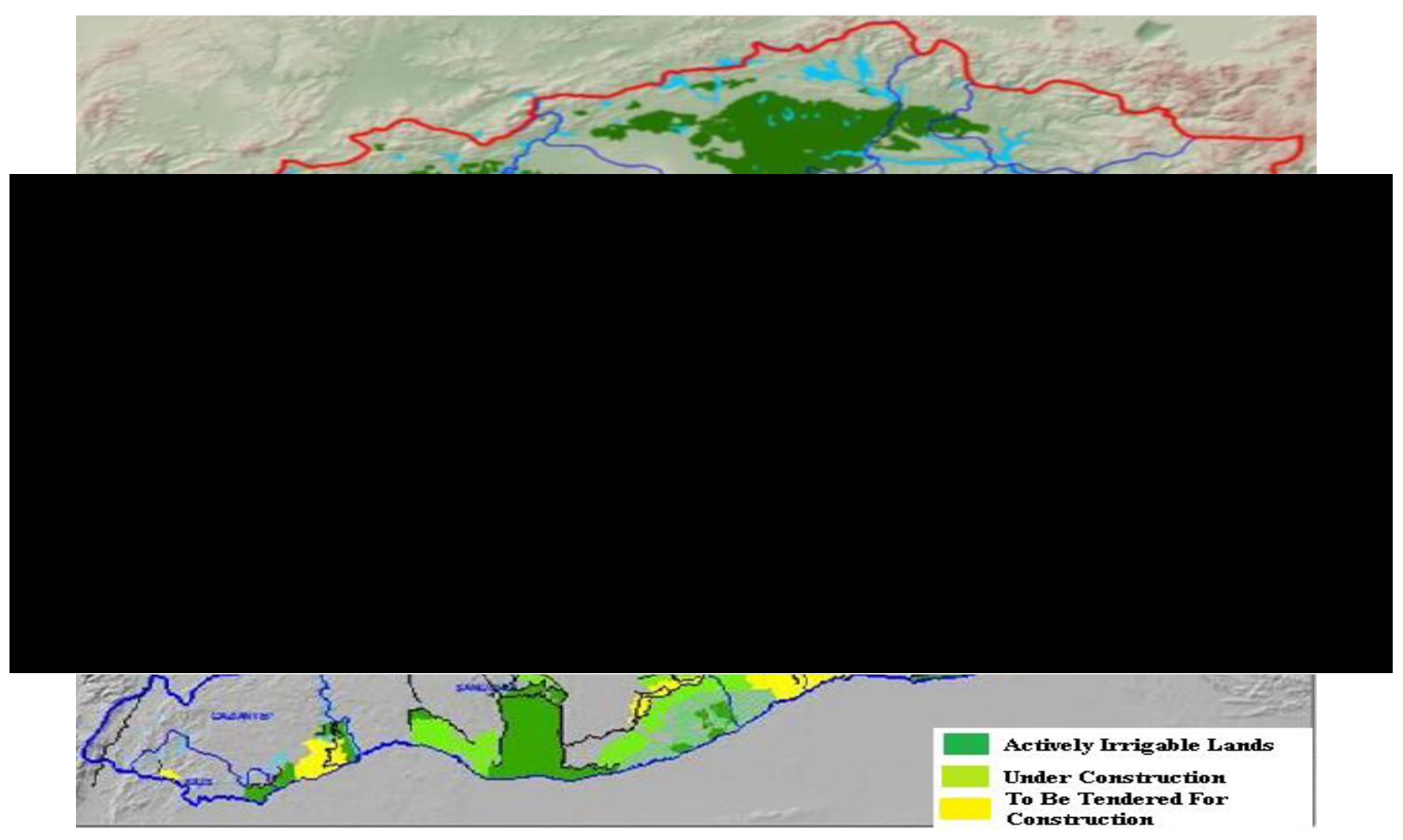

Figure 4.7 The Areas Intended to Be Irrigated within the Scope of the GAP in 2015, Adapted from Erşan (n.d.)

The land available for agricultural production in the SAR is $42 \%$ (7.5 million ha), and around $44 \%$ of this is allocated for vegetative production. Pastures, and forests and shrubberies

\footnotetext{
${ }^{54}$ Here, we keep ourselves away from any discussion about the tribal or semi-feudal system. The traditional peasantry in the sense of a class that exists in a feudal system has already been disintegrating since the 1950s. Agricultural mechanisation, the destructive effects of the armed conflict and the neoliberal agricultural transformation that has obstructed the sharecropping system by lowering crop prices and profit margins are all factors here.
} 
respectively cover around $29.5 \%$ and $19 \%$ of these (The GAP-RDA, 2018, p. 23). The SAR's potential irrigable land accounts for 2.1 million ha, $26 \%$ of which is actively irrigated presently (The GAP-RDA, 2018). The upper half of Figure 4.7 shows the areas that were planned to be irrigated within the scope of the GAP: around 1.8 million ha. The lower half of the figure displays the actual state of those areas in 2015. A large part of the light green areas are now under operation, too.

AEs located in the plains or low-elevation areas (see Figure 4.8) partly take advantage of irrigation, surface and ground water. AEs in villages located in valleys, which the Euphrates and Tigris and their tributaries have shaped, can also appropriate water to cultivate crops. The rest is supposed to grow crops under rain-fed conditions. Agro-ecological, climatic and geographical conditions of the region allow AEs to grow different types of crops according to their sizes.

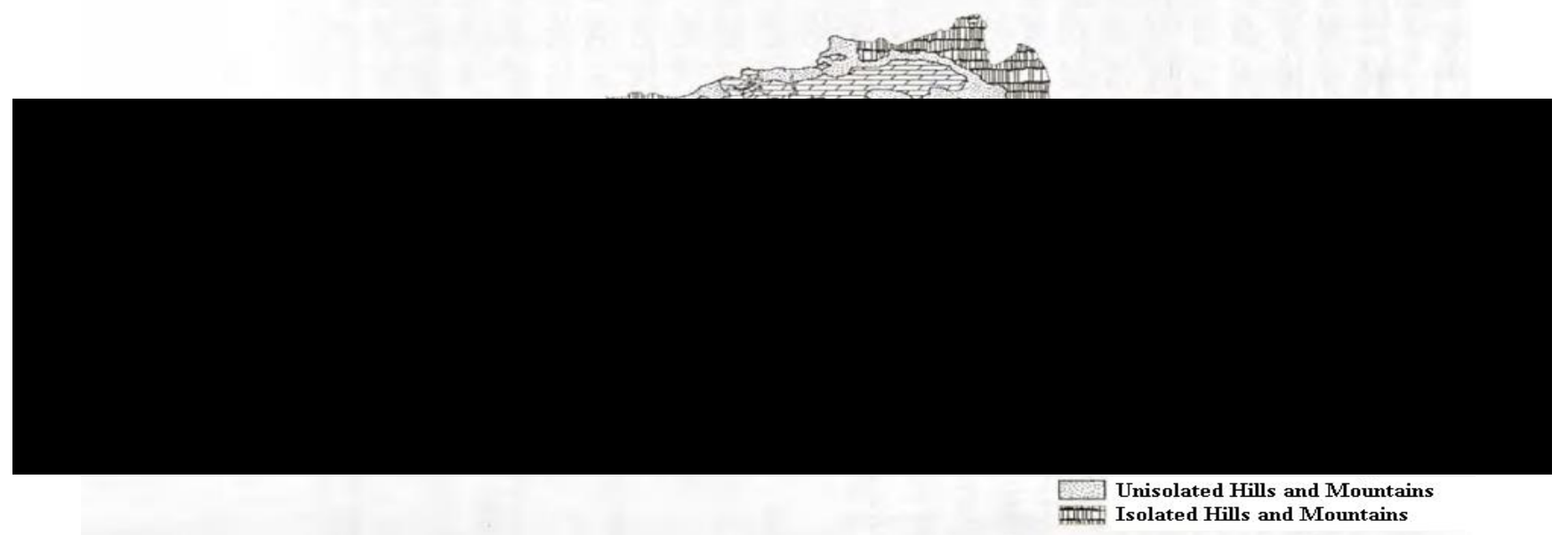

Figure 4.8 The Main Geographical Features of the SAR, Reproduced from The GAP-RDA (2002a, p. 174)

Under Mediterranean climate conditions, summers are hot and winters temperate, although the north SAR is colder than the south SAR during the winter. The average annual precipitation level is ranked the second lowest among Turkey's regions (The General Directorate of Meteorology, 2018). The south SAR is semi-arid, the north and east SAR semi-humid, the area between both of them and the north-west and west SAR semi-arid but low-humid (The General Directorate of Meteorology, 2016). These climatic conditions influence the agro-ecological conditions of the region, and thus land utilisation. As seen in Figure 4.6, field crops are commonly be grown in more fertile plains and relatively lowelevation areas. Highly profitable pistachio and olive trees are mostly planted in poor, stony 
and arid lands of low-elevated areas. Various types of fruits and vegetables tend to be grown in relatively high-elevation areas. Livestock production tends to take place in areas close to pastures, mostly in high-elevation areas. Modern livestock facilities that have been set up in low-elevation areas in the last decade, furthermore, contribute to this. Table 4.14 shows what crop types are most commonly grown in the cities of the SAR. Note that field crops (around $79 \%$ ) outweigh fruits (around 18.70\%) and vegetables (around 2.30\%) in production (Turkish Statistical Institute, 2017b), as displayed in Table 4.15.

\begin{tabular}{|c|c|c|c|}
\hline Cities & Fieldcrops & Vegetables & Fruits \\
\hline Adiyaman & $\begin{array}{c}\text { Wheat, Barley, Vetch, Chickpea, } \\
\text { Red Lentil, Cotton, Tobacco, } \\
\text { Maize }\end{array}$ & $\begin{array}{l}\text { Watermelon, Melon, Bell } \\
\text { Pepper, Garlic }\end{array}$ & $\begin{array}{l}\text { Grape, P istachio, Almond, } \\
\text { Walnut, Pomegranate, Olive }\end{array}$ \\
\hline Batman & Wheat, Barley, Red Lentil, Maize & $\begin{array}{l}\text { Watermelon, Melon, } \\
\text { Tomato }\end{array}$ & Grape, Pistachio \\
\hline Diyarbakir & $\begin{array}{c}\text { Wheat, Barley, Vetch, Chickpea, } \\
\text { Red Lentil, Cotton, Maize, } \\
\text { Sunflower, Paddy }\end{array}$ & $\begin{array}{c}\text { Watermelon, Melon, } \\
\text { Tomato, Bell Pepper, Green } \\
\text { Pepper, Cucumber, Onion, } \\
\text { Aubergine }\end{array}$ & Grape, Plum, Mulberry \\
\hline Gaziantep & $\begin{array}{c}\text { Wheat, Barley, Vetch, Chickpea, } \\
\text { Red Lentil, Cotton, Maize, Sugar } \\
\text { Beet }\end{array}$ & $\begin{array}{c}\text { Watermelon, Melon, } \\
\text { Aubergine, Garlic, Mint, Red } \\
\text { Pepper, Onion, Cucumber }\end{array}$ & $\begin{array}{c}\text { Grape, Apple, Cherry, } \\
\text { Pistachio, Olive, Walnut, } \\
\text { Pomegranate }\end{array}$ \\
\hline Kilis & $\begin{array}{c}\text { Wheat, Barley, Cotton, } \\
\text { Chickpea, } \\
\text { Red Lentil }\end{array}$ & Red Pepper, Onion, Tomato & Grape, Pistachio, Olive \\
\hline Mardin & $\begin{array}{c}\text { Wheat, Maize, Red Lentil, } \\
\text { Barley, } \\
\text { Chickpea, Cotton }\end{array}$ & $\begin{array}{c}\text { Watermelon, Melon, Cucumber, } \\
\text { Gherkin, Tomato }\end{array}$ & Grape, Cherry, Olive, Pistachio \\
\hline Siirt & $\begin{array}{c}\text { Wheat, Barley, Vetch, Maize, } \\
\text { Red Lentil }\end{array}$ & Tomato, Melon & Grape, Pistachio \\
\hline Sanliurfa & $\begin{array}{c}\text { Wheat, Barley, Vetch, Red } \\
\text { Lentil, Cotton, Maize, } \\
\text { Sunflower, Sugar Beet, Clover, } \\
\text { Sesame }\end{array}$ & $\begin{array}{c}\text { Watermelon, Melon, Red } \\
\text { Pepper, Bell Pepper, Cucumber, } \\
\text { Aubergine, Gherkin, Onion, } \\
\text { Tomato }\end{array}$ & $\begin{array}{l}\text { Grape, Pistachio, Almond, } \\
\text { Olive, Pomegranate }\end{array}$ \\
\hline Sirnak & $\begin{array}{l}\text { Wheat, Maize, Barley, Red } \\
\text { Lentil, } \\
\text { Cotton, Clover, Peanut, Vetch }\end{array}$ & Watermelon & Grape \\
\hline
\end{tabular}

Table 4.14 The Most Cultivated Crop Types in the SAR's Cities in 2017 (Turkish Statistical Institute, 2017b $)^{55}$

\footnotetext{
${ }^{55}$ Red-coloured crop types are the most grown in each category.
} 
In terms of land ownership, LAEs tend to be more common in low-elevation areas rather than high-elevation areas, and SAEs tend to be more common in high-elevation areas rather than low-elevation areas (Gürsoy, Sessiz, Eliçin, Akın, \& Esgici, 2013). The structure of land ownership and the possibility of accessing irrigation relate to agricultural mechanisation. LAEs rely more on agricultural mechanisation than SAEs, and they tend to use it more for irrigated farming, which allows a wider range of crop types to be cultivated several times. Again, AEs located in plains and low-elevation areas are more likely to use agricultural mechanisation more than those in high-elevation areas (Gürsoy et al., 2013).

\begin{tabular}{|l|c|c|c|}
\hline Cities & Fieldcrops & Vegetables & Fruits \\
\hline The SAR & $78.94 \%$ & $2.30 \%$ & $18.76 \%$ \\
\hline Gaziantep & $38.04 \%$ & $2.78 \%$ & $59.18 \%$ \\
\hline Adryaman & $76.14 \%$ & $2.41 \%$ & $21.45 \%$ \\
\hline Kilis & $44.24 \%$ & $4.74 \%$ & $51.01 \%$ \\
\hline Şanluurfa & $85.25 \%$ & $1.81 \%$ & $12.95 \%$ \\
\hline Diyarbakır & $93.17 \%$ & $2.38 \%$ & $4.45 \%$ \\
\hline Mardin & $84.87 \%$ & $2.45 \%$ & $12.68 \%$ \\
\hline Batman & $84.40 \%$ & $3.20 \%$ & $12.40 \%$ \\
\hline Şrnak & $95.13 \%$ & $1.24 \%$ & $3.63 \%$ \\
\hline Sïrt & $71.03 \%$ & $2.58 \%$ & $26.39 \%$ \\
\hline
\end{tabular}

Table 4.15 The Shares of Areas Allocated for Field Crops, Vegetables and Fruits (Turkish Statistical Institute, 2018a)

As the Turkish Statistical Institute conducted their last agricultural census in 2001, we do not know how agricultural enterprises and landownership in the SAR have altered in the last 17 or 18 years. Table 4.16 shows however that there is an unfair land distribution in favour of LAEs and against SAEs in the region, and it seems that this tendency is stronger in the East SAR than the West SAR. 2.95\% of total AEs in the region control around $31.70 \%$ of agricultural land whilst around $72 \%$ of total AEs only possess around $22.15 \%$ of agricultural land. The land controlled by all the LAEs in the region is 1.43 times more than those controlled by all the SAEs; for Turkey, the ratio is only around 0.27 . 


\begin{tabular}{|c|c|c|c|c|c|c|c|c|c|c|c|c|}
\hline Size (da) & Unit of Criterion & Adiyaman & Diyarbakir & Gaziantep & Mardin & Siirt & Sanliurfa & Batman & Sinnak & Kilis & The SAR & Turkey \\
\hline \multirow[t]{2}{*}{$0-20$} & Number (\%) & 33.55 & 33.07 & 22.64 & 37.20 & 62.83 & 5.75 & 24.13 & 16.16 & 10.31 & 27.18 & 33.36 \\
\hline & Land $(\%)$ & 6.78 & 4.08 & 2.07 & 3.78 & 10.86 & 0.33 & 2.78 & 0.75 & 1.29 & 2.45 & 5.32 \\
\hline \multirow[t]{2}{*}{ 20.01-50 } & Number (\%) & 39.19 & 32.82 & 20.45 & 19.85 & 21.01 & 19.24 & 26.18 & 25.67 & 34.78 & 26.23 & 31.46 \\
\hline & Land (\%) & 25.02 & 9.92 & 6.56 & 6.90 & 17.00 & 3.31 & 10.11 & 5.67 & 12.96 & 7.77 & 16.02 \\
\hline \multirow[t]{2}{*}{$50.01-100$} & Number (\%) & 16.43 & 14.00 & 22.62 & 18.15 & 6.26 & 25.12 & 20.53 & 16.57 & 26.99 & 18.58 & 18.53 \\
\hline & Land $(\%)$ & 22.90 & 9.19 & 15.31 & 14.46 & 9.92 & 8.68 & 17.43 & 8.04 & 20.82 & 11.92 & 20.68 \\
\hline \multirow[t]{2}{*}{ Sub Total } & Number (\%) & 89.17 & 79.89 & 65.71 & 75.20 & 90.10 & 50.11 & 70.84 & 58.40 & 72.08 & 71.99 & 83.35 \\
\hline & Land $(\%)$ & 54.70 & 23.19 & 23.94 & 25.14 & 37.78 & 12.32 & 30.32 & 14.46 & 35.07 & 22.14 & 42.02 \\
\hline \multirow[t]{2}{*}{$100.01-20$} & Number (\%) & 7.16 & 8.59 & 20.94 & 12.71 & 5.54 & 25.00 & 16.57 & 19.08 & 19.25 & 14.75 & 10.83 \\
\hline & Land $(\%)$ & 20.12 & 11.49 & 27.66 & 20.10 & 17.85 & 16.96 & 26.88 & 17.27 & 27.41 & 18.60 & 23.81 \\
\hline \multirow[t]{2}{*}{$200.01-50$} & Number (\%) & 3.26 & 7.66 & 11.02 & 10.00 & 2.83 & 19.18 & 11.77 & 16.37 & 7.29 & 10.31 & 5.10 \\
\hline & Land (\%) & 15.64 & 24.12 & 30.24 & 34.92 & 18.72 & 27.29 & 37.20 & 32.38 & 21.79 & 27.55 & 22.82 \\
\hline \multirow[t]{2}{*}{ Sub Total } & Number (\%) & 10.42 & 16.25 & 31.96 & 22.71 & 8.37 & 44.18 & 28.34 & 35.45 & 26.54 & 25.06 & 15.93 \\
\hline & Land $(\%)$ & 35.76 & 35.61 & 57.90 & 55.02 & 36.57 & 44.25 & 64.08 & 49.65 & 49.20 & 46.15 & 46.63 \\
\hline \multirow[t]{2}{*}{$500.01+$} & Number $(\%)$ & 0.41 & 3.86 & 2.33 & 2.09 & 1.53 & 5.71 & 0.82 & 6.15 & 1.38 & 2.95 & 0.72 \\
\hline & Land $(\%)$ & 9.54 & 41.20 & 18.16 & 19.84 & 25.65 & 43.43 & 5.61 & 35.89 & 15.73 & 31.71 & 11.35 \\
\hline \multirow[t]{2}{*}{ Total } & Number (\%) & 100.00 & 100.00 & 100.00 & 100.00 & 100.00 & 100.00 & 100.00 & 100.00 & 100.00 & 100.00 & 100.00 \\
\hline & Land $(\%)$ & 100.00 & 100.00 & 100.00 & 100.00 & 100.00 & 100.00 & 100.01 & 100.00 & 100.00 & 100.00 & 100.00 \\
\hline
\end{tabular}

Table 4.16 The Percentage Distribution of Number and Land Share of AEs in the SAR and Turkey in 2001 by Size (Turkish Statistical Institute, 2001)

\subsection{Conclusion}

This section started with a discussion of the neoliberal agricultural transformation in Turkey and proceeded to explain its evolved character and interactions with Turkey's political economic terrain and economic classes. Turkey's agricultural economy has performed worse during the neoliberal period than during the developmentalist era. Also, the neoliberal transformation greased the wheels of Islamism and Islamist bourgeoisie in the 1980s and 1990s, in opposition to the military-bureaucratic class and the secular bourgeoisie, which managed to direct the long-standing reaction of the Islamist people in the periphery via religious community networks to their interests in the name of Islamic brotherhood.

Another reaction from the periphery came from Kurds, who mobilised under the PKK. The armed conflict started in 1984 and ended in 1999 with the arrest and imprisonment of the PKK leader Ocalan. One of the results of the armed conflict was the special-war regime set up by the high-level military commanders. The operation and political costs of such a regime provoked negative reactions by the secular bourgeoisie over time; in other words, the central coalition started to corrode in the mid-1990s.

One of the attempts to halt the PKK was to introduce a development plan in the SAR. We elaborated how this plan was first created and evolved in the national course of political economy interacting with changes in neoliberalism on the global level. The SAR's agriculture used to rely on pre-capitalist farmers subject to subsistence farming prior to the armed conflict. In the course of the armed conflict, the coercion applied by the state turned 
this agricultural structure into a market-oriented one rather than the development plan itself, of which the execution was partly hampered by economic crises. Furthermore, the neoliberal agricultural transformation apparently did not help the region to close the developmental gap. Per capita income of the region is still half of the country's average, and poverty is prevalent. It however appears that the government interventions under the development plan have generally produced good results in Sanliurfa's economy, making the state more determined to follow the plan. We can conclude that if government interventions had not been implemented, the developmental gap between the region and the most developed regions would have widened. 


\section{Chapter 5: Turkey's Political Economy and the Kurdish Question Since 2001}

\subsection{Introduction}

This analysis chapter seeks to understand why Turkey has, since 2001, simultaneously implemented both neoliberal agricultural policies and government interventions for agricultural development in the SAR. This requires to examine the role of politics in framing development policies between 2001 and 2017. The concurrent application of neoliberal agricultural policies and governmental interventions are a derivative of the political contest within the dominant coalition and between the centre and the periphery.

After critically assessing Violence and Social Orders written by North et al. (2009), we argued that focussing on intra-elite relationships in the dominant coalition can partly help us to understand changes in state formations, and that the conflicting interaction between the centre and the periphery should also be taken into account to comprehend intra-elite relationships and changes in the dominant coalition and state formation.

Shaped on conflicting interests, complicated political interactions within the dominant coalition and between the centre and the periphery in Turkey since 2001 are the main issues to be assessed. We shall discuss how intra-elite relationships have developed and transformed within the dominant coalition, and how the periphery has influenced those relationships, pursuing their own interests.

In the context of the political conflicts, neoliberal transformation and populism has played an important role in forming alliances in the dominant coalition, to shape the periphery and to get support from external forces to consolidate political power.

The political conflict between the Islamic movement and the Kemalist or secular establishment has shaped agricultural policies. The JDP government, representing interests of the conservative bourgeoisie, came to power with the support the conservative people in the periphery. When the government was faced with resistant from the secular elites and periphery, they needed to get the support of international organisations, Western states and the large-scale secular bourgeoisie having partnerships with Western corporations. They have determinedly followed neoliberal policies at the national level to raise their power in domestic politics and isolate the secular establishment.

The Kurdish question and the Kurdish political movement with its growing social capital have driven the government to engage in development interventions. The military narrative 
had given power to the military in the 1990s. The JDP government intended to prevent any increase in the power of the military, so attempted to satisfy the ordinary Kurds with democratic openings and development. As they became the second most popular party in the SAR in the 2002 general election, they also planned to cut the support of ordinary Kurds to the Kurdish political movement so that they would firmly establish their legitimacy in the dominant coalition, and among ordinary people by promoting themselves as peacemakers. As a result, neoliberal policies at national level have been coupled with development interventions, especially in the scope of the GAP-based agricultural projects in the SAR.

A promising, peaceful environment shaped the SAR between 2009 and 2015, especially after the government initiated the Kurdish Opening in 2013. For a few years, Kurds had access to country-wide political bodies and promoted their views among the Turkish population. The strategy - called 'becoming part of Turkey' (Türkiyelileşmek) - prevailed among Kurds, along with democratisation processes, and as a result, regionalism remained less attractive.

After the June 2015 election, the JDP government saw that democratic openings and peace talks had benefitted the Kurdish political movement more than the JDP. Alarming with the Kurdish forces that expanded their territories in Syria, the government started to suppress the Kurdish political movement limiting their political access and participation.

While addressing Bates' views about regionalism, we objected to his argument that regional cultural, political and economic diversities leads to regionalism which shapes the political terrain in a way that obstructs political economic development. From our standpoint, regionalism emerges or gains strength, where a high degree of centralisation restricts political access and participation. In the case of the Kurdish Question, Kurds abandoned their strategy, called 'becoming part of Turkey', and reverted to regionalism because the highly centralised state regarded their political extension to other people in Turkey politically risky to the dominant coalition.

In this context, the course of the Kurdish question in the period between 2001 and 2017 will be our main focus. We will see that the Kurdish question provided an arena, where the interplay between three political forces took place: the JDP government, the militarybureaucratic class and the Kurdish political movement.

International political actors influenced this political interplay. Nyeck (2010) makes a critical assessment on When Things Fell Apart written by (Bates, 2008) that "[i]n emphasizing rational choice and decision-making, Bates neglects the international dealings of rulers of 
weak states and the outcomes of international bargains on either failure or relative strength of the 'specialists in violence'."

It was discussed earlier that the military-bureaucratic class and their representatives in politics adapted themselves flexibly to changing international power structures, and thus, the state with its dominant coalition engaged in international dealings to keep their power and the creation of systematic rents. International bargains have inevitably shaped the political terrain of Turkey. For example, in line with the strategy of the West, Turkey fought with communism in Turkey. During this fight the state control over Islamism was relaxed; nationalist policies were advanced; the Kurdish Question was attempted to be solved by coercive acts. The chapter will show that JDP government skilfully tapped the relationships with the EU, the US and international organisations in order to outperform its political rivals and receive assistance for the developmental efforts in the SAR. The implementation of neoliberalism has surely been part of these international dealings, and later financial and technical assistance for development became part of them. Furthermore, development interventions in agricultural development of the SAR were a product of international dealings and plans with the West in the Middle East.

The combined implementation of neoliberal policies and development interventions in agricultural development of the SAR were the result of the political factors we have explained. Figure 5.1 shows the share of GAP investment expenditures in the total public investments in Turkey. After the 2001 economic crisis, the share declined and remained below the average level of the 1990s. From when the JDP government overruled the military after 2007, they found a chance to carry out their grand strategy in the Middle East. The share of public expenses for promoting agricultural development increased during the period of democratic openings. After the military narrative came to the fore in 2015 as Turkey's economic performance was gradually deteriorating, the share declined again.

In the second section, we will address the conflicting relationship between the JDP government and the military bureaucratic class. In the third section, we will address the changing political course of the Kurdish question in the political struggle between the centre and the periphery, particularly taking account of the relation between the development narrative and the military narrative. In doing all, we will emphasize the influence of international relations on the political course of the Kurdish Question. The fourth section will synthesize what we discuss in the chapter, and the conclusion section will summarise the entire chapter. 


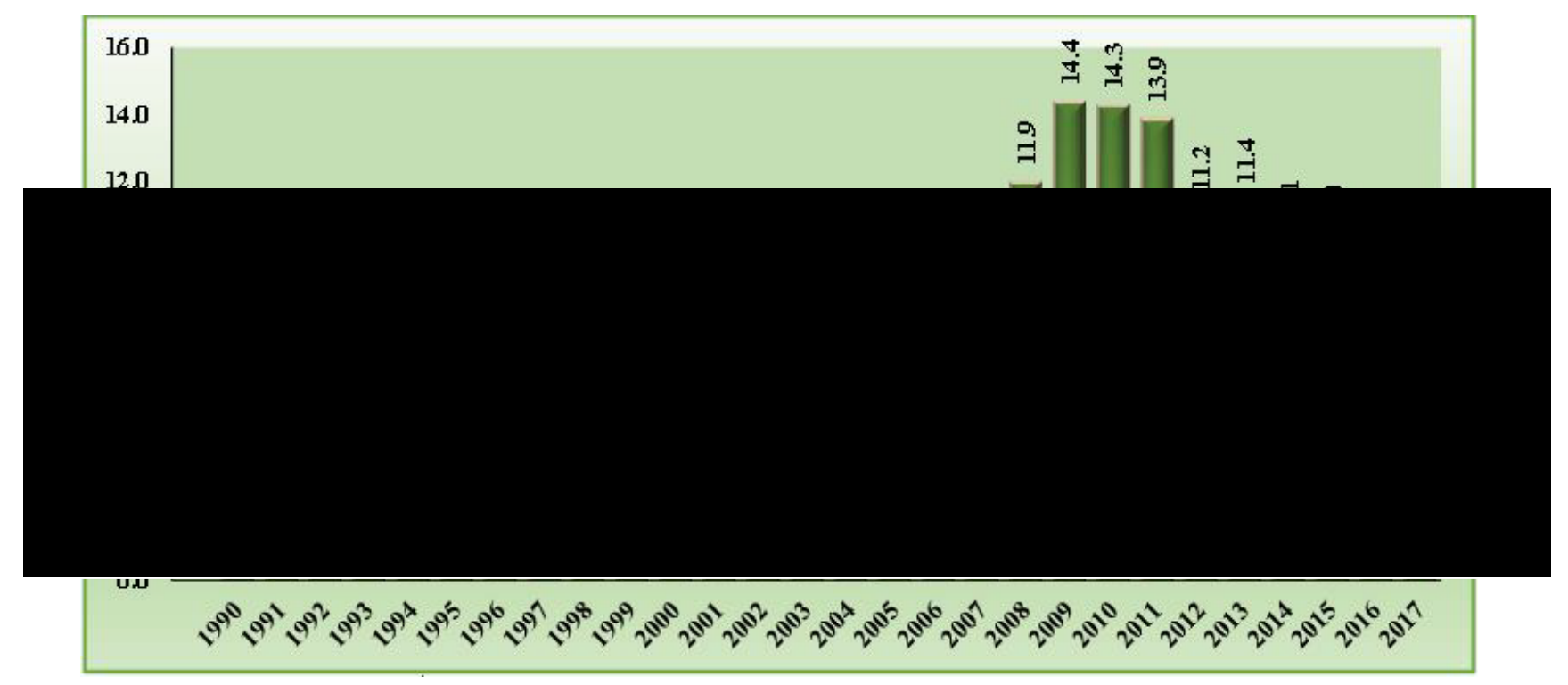

Figure 5.1 The Percentage Values of Public Investment in the GAP Reproduced from The GAP-RDA (2018, p. 19)

\subsection{The Conflicting Relationship between the JDP Government and the State Bureaucracy}

A brief summary of the composition of the dominant coalition in the early 2000 s is needed before starting our analysis. The military bureaucracy, orchestrating components of the state bureaucracy (i.e. the judiciary, the Council of Higher Education responsible for universities) in times of political crisis, was filling the central or core position in the dominant coalition. Their ally in the dominant coalition was the secular, westernised bourgeoisie in west Turkey. The coalition government parties, loyal to the Kemalist ideology endorsed by the military bureaucracy, had been unable to provide a solution to the Kurdish question or the thorny economic problems frustrating the capital accumulation process before 2002.

Whilst the military bureaucracy had managed to arrest the rise of the working class and Kurds in the 1970s, they had opened the way for Islamisation, which would later came back to undermine its political power. The WP came to power in a coalition government in 1996 but was ousted from power through a military coup. Afterwards, the conservative bourgeoisie changed their strategy and aligned themselves with the EU and the US (Kucukaydin, 2013b, pp. 40-41). After the 2001 economic crisis, the JDP, representing the conservative bourgeoisie, gained support of those who were highly dissatisfied with economic hardships. This led to a political economic conflict between conservative and secular elements of the periphery. 


\subsubsection{The State Bureaucracy Attacks on the JDP Government}

The outcome of the general election held in November 2002 was a shock to the system. The coalition parties and opponent parties were all blamed for economic and political crises and corruption during the $1990 \mathrm{~s}$, and voted out of parliament. It was clear that the centralised state was faced with a legitimacy crisis (Yildirim, İnaç, \& Özler, 2007). Subscribing to market economy underpinned with statism, the CHP, which secured around $20 \%$ of the votes, was representing most secular Sunni, Alevis and state officials. The JDP, the other party in parliament, had been established in 2001 by the some political notables having left the banned Virtue Party ${ }^{56}$. The JDP leaders, called themselves conservative democrats rather than Islamists, and secured just over $34 \%$ of the votes, representing the interests of conservative Muslims and the conservative bourgeoisie. The result of the election provided a great opportunity to the Islamists and/or conservatives to 'restructure political landscape and expand the public sphere' (Yavuz, 2003, p. 256). However, it was difficult to formulate and implement cross-cutting policies to satisfy three different sets of demands: state demands, demands from their political base, and global demands (Yildirim et al., 2007).

Given that there was a pressing need for tackling economic problems, the JDP government's efforts centred on this first. They, over time, achieved high growth rates and low inflation rates and integrated Turkey more into the global market by adopting 'conservative globalism', the synthesis of liberalism and conservatism, which made possible the attainment of wide support from different socio-economic groups despite heavy social costs of the standby programme (Öniş, 2009). To succeed, they only followed the neoliberal recipe having provided by the IMF to the then coalition government after the 2001 economic crisis, so gained some credibility from the international economic organisations.

They also improved their relationship with the EU, complying with the Copenhagen Criteria: a set of institutions and standards of democratisation (E. Doğan, 2005). In an attempt to consolidate and expand their constituency, they occasionally engaged in contested topics conducive to widen the secular-conservative cleavage and entered into ethnic discourse. This triggered resistance and scepticism not only "from the central elite but also from the traditional block of the right and the left" (Yildirim et al., 2007).

\footnotetext{
${ }^{56}$ The Virtue Party was the successor to the WP, which was banned from politics in 1998 after the military bureaucracy had taken the 28 February measures. The Virtue Party was later banned in 2001, being accused of violating the secular order.
} 
The confrontation between the JDP government and the secular establishment peaked in 2007 with the presidential election. The likelihood of a person with political Islamic views to be selected as the next president was the main issue between the two political sides. After Erdogan proclaimed that Abdullah Gul, a founder of the JDP and the minister of foreign affairs, would be the candidate of the party for the presidential election, resentment among the CHP's representatives grew further.

While boycotted by all opposition parties, Gul was selected as the president. The CHP appealed at Constitutional Court to cancel the decision, arguing that the required quorum was not constitutional. On $27^{\text {th }}$ April 2007, the General Staff declared an 'e-memorandum' (emuhtıra in Turkish) highlighting that they would defend secular principles, relying on their mandate from the legal framework of the state ("A Declaration from the General Staff," 2007, 27 April). The then president of Turkey, Ahmet Necdet Sezer, had already claimed that the country's regime was under an unprecedented threat where internal and foreign forces were cooperating to change the secular republic into a moderate Islamic one ("The Sezer's Speech," 2007, 13 April). Furthermore, the stormy but inconclusive Republican meetings against the JDP government took place in five cities. Hundreds of thousands from the secular periphery gathered in each meeting, of which many were the wage earners espousing the revitalisation of Kemalism, referring to the founding principles and ideology of the Republic (Yasli, 2014, p. 134).

The Court cancelled the decision made by parliament, and another session was convened. But the president could not be selected, as the required quorum could not be attained. Erdogan, in response, called for a general election and a constitutional change that would allow the people to elect the president. The people in the periphery with right-wing views and those who benefitted from policies of the JDP government brought succour to him during the election. The JDP ended up increasing its votes from $34 \%$ to around $46.5 \%$, the CHP lost seats while the NMP entered parliament again. Gul was selected by parliament as the president of Turkey in August 2007. The constitutional change was also accepted in a referendum. However, the challenge against the JDP government from the secular establishment did not stop. A final step was to open a legal investigation for the closure of the JDP; yet, the constitutional court rejected the closure.

In conclusion, the military bureaucracy, the judiciary and the CHP attempted until 2008 to remove the JDP government from power and to discredit them in the eyes of the people. The deadlock at the elite-level was only overcome when the conservative periphery did not take a 
step back and supported the JDP government. Particularly, the right-wing people who had not give their votes to the JDP in the 2002 general election, backed the ruling government in the 2007 general election. Consequently, the reaction of the periphery to the centre brought a great chance to the JDP to shape the dominant coalition.

\subsubsection{The JDP Government Gains the Upper Hand}

We will now discuss how Erdogan and his the JDP government has strengthened his political power and gained the upper hand since 2002. After 2007 he has had nearly undisputed political power, through social capital among elites and the ordinary conservative people in the periphery. The implementation of neoliberal policies have become imperative for his government to gain legitimacy from different actors and keep his power since they came to power.

As Teazis (2010, pp. 16-18) argues, the JDP's political identity originates from the Second Group $^{57}$ in the first parliament that was founded during the Independence War, which espoused to attract foreign investors and set up a liberal conservative order. Following the Second Group, the DP in the 1950s (Aydin, 2005, p. 28; Teazis, 2010, pp. 21-24), the National Order Party and the National Salvation Party in the 1970s, the WP in the 1980s1990s (Yavuz, 2003, pp. 212-213), all gave importance to market-based development and the freedom of religion in a liberal, religion-based democracy. This political tradition allowed the party elites to accommodate the political economic needs of global and national capitalists under the neoliberal regime, obtaining consent from the poor through conservative values and a conservative political agenda (Öniş, 2009).

After the WP and the Virtue Party were banned subsequently because of their violations on secular principles in the constitution, the reformists in the Virtue Party well defined the reality that if they did not modernise their views, the conservative bourgeoisie with liberal conservative values would not back them, who had been economically harmed with the measures and strict inspections applied by state after the 28 February measures (Yildirim et al., 2007). When the reformists constituted a new party, the JDP, they invited many politicians from other centre-right wing parties to their cadres (Teazis, 2010, pp. 135-136). After forming their elite-cadres, the JDP altered their programme in accord with the actual political economic conditions. In the party programme, the JDP adopted cosmopolitan views instead of strong nationalism; decentralisation and good governance rather than

\footnotetext{
57 The Second Group was composed by the representatives who objected to the First Group that would later found the Republic under the leadership of Ataturk.
} 
centralisation; the full extent of neoliberal and foreign investors-friendly policies refusing redistributive policies of the state; a wider range of human rights rather than solely religious rights; good orientation to the Western institutions and a balanced approach to the Middle East instead of anti-Western and anti-Israel political positions (Öniş, n.d.).

Their orientation to Western political interests and neoliberal economic policies helped the government gain support from the global capitalist classes, the US and the EU (Savran, 2015, p. 68). No matter how the secular bourgeoisie had some interest conflicts with the conservative bourgeoisie, they supported the single party government executing neoliberal reforms (Savran, 2004, p. 36). Erdogan eventually bypassed the parliament in the following years, and his government implemented unpopular policies at the expense of the working class; for example, 80 per cent of privatisation realised in the last three decade have been made by the JDP government (Savran, 2015, pp. 68-69). Being backed by the entire bourgeoisie and western countries, the JDP government managed to isolate the state bureaucracy in the political arena.

Here we should ask how Erdogan acted at the expense of the working class (or the periphery) while at the same time maintained their consent. Remember that before the JDP came to power, different elements of the dominant coalition (i.e. the existing parties, state officials and the secular large-scale capitalists) had lost their credibility in the eyes of the of people because of economic problems and corruption (Laçiner, 2001). Until the JDP closure trial in 2008, the government managed to achieve high economic growth rates (averagely $7.9 \%$ ) and low inflation rates (Turkish Statistical Institute, 2017e); per capita income increased by around 1.9 times in the period between 2002 and 2010 (Öniş, 2012). It was realised through fiscal and monetary stability attracting high capital flows to the national economy under neoliberal policies, which grew domestic credits and led to exchange rates under a free floating currency regime, thus lowering perceived prices of imported goods (Öniş, 2012). This enabled the incumbent government to apply neoliberal populism and design redistributive mechanisms, which reduced poverty from $27 \%$ in 2002 to $18 \%$ in 2009 (Öniş, 2012). This economic circumstance was what helped the JDP government to defeat rival parties and to successfully obtain high electoral support from the working class

Furthermore, the establishment had showed weakness in being able to deliver aid to those affected by the 1999 earthquake (Engin, 1999). Given that the military bureaucracy had also fuelled resentment among Kurds during the armed conflict and among the conservative 
because of 28 February measures, the majority of the people or the working class lost its trust in the state. All of these factors strengthened the JDP's hand in the political contest.

Another factor explaining the support of the working class comes from the existing cultural cleavage across the working class. Perceiving this cleavage, Erdogan augmented cultural polarisation intentionally to divide and rule the working class and the middle class, obtaining votes under the guise of a cultural struggle for the oppressed (Kucukaydin, 2013b, pp. 43-48; Savran, 2015, pp. 70-71). He later exploited this cultural struggle to socially construct a Sunni nation interacting with the idea of Neo-Ottomanisation, a strategic initiative to revitalise Ottoman-like hegemony in the Middle East under the guise of "brotherhood" among Sunni Muslims (Yasli, 2014, pp. 55-61, 163-166). ${ }^{58}$

The JDP government also created privileges for the conservative periphery to maintain their electoral support. The clash between the middle classes from different social strata to fill mid-and senior-level posts within the state bureaucracy and local municipalities, and jobs in the private sector (Savran, 2015, p. 46) becomes evident from the following:

There is cutthroat competition between the formerly hegemonic intellectual and professional elites reared in well-to-do families in big cities and educated at the cream of Turkish universities or abroad, often polyglot and wielding a cosmopolitan outlook and lifestyle, on the one hand; and a newly rising layer with the same professional qualifications, but mostly coming from poorer families residing in small towns or even villages, some educated in the new provincial universities of Anatolia [...], usually at a disadvantage when it comes to speaking foreign languages $[\ldots]$ and with a more restricted outlook on the world and a more conservative lifestyle, on the other hand.

The JDP government opted for employing the latter group to consolidate its political base by monopolising public jobs (Yilmaz \& Bashirov, 2018). While neoliberal policies were coupling with development interventions, the conservative educated people were employed in the existing and newly founded organisations in the field of development, such as development agencies, the Agricultural and Rural Development Support Institution, the GAPRDA and its affiliated organisations.

\footnotetext{
${ }^{58}$ The harsh response to this cultural polarisation as well as neoliberal policies was the Gezi Protests, taking place in May-June 2013, which symbolised greatly the rising reaction of 'an emerging new middle class and a declining/proletarianizing middle class' and partly of students and workers with Alevi or Kurdish background (Yörük, 2014). All of which can be classified from cultural aspects as republicans, socialists, Alevis, LGBT individuals58, and secular Kurds and women from the periphery (Yasli, 2014, pp. 186, 203).
} 
The JDP government and local municipalities also nourished the growth of the Anatolian conservative bourgeoisie, and businessmen strongly loyal to Erdogan (Esen \& Gumuscu, 2018; Yilmaz \& Bashirov, 2018). Though the incumbent government was relatively more willing to allow auditing over public expenditures between 2002 and 2007, in the following years, they gradually lifted the judicial auditing and relaxed enforcement over public expenditures or procurements (Esen \& Gumuscu, 2018). ${ }^{59}$ Since the JDP government back the Anatolian bourgeoisie, the small- and medium-scale enterprises that deal with them benefit from that backing, and thus align themselves with the ruling party. In the case of the SAR, they are supported by project and programmes created within the GAP, and thus, the government confidently secures its political base in the SAR.

In the same vein, the workers employed by the business groups and the municipalities the JDP holds also align themselves with the politics of the ruling party (for example; Artigercek, 2018, 04 June; A. Çelik, 2008, 24 July; Köseoğlu, 2014, 19 May). Aside from this, probing three subsequent general elections between 2002-2001, Çarkoğlu (2012) attributes the JDP's subsequent electoral victories to 'a partisan commitment' among their voters. More strikingly, the JDP won another victory in the 2013 local election despite corruption allegations, underpinned with leaked recordings of top-level government officials.

The final crucial factor in explaining JDP's political power is the networks of Islamic orders or communities, which function as intermediary entities between a large group of adherents and the party in generating consent for the ruling government. Capable of politically controlling their members with their economic and social resources, the Islamic orders own holding companies to help sustain their power (Ö. Öztürk, 2015).

To resist the political attacks of the military bureaucratic class, Erdogan did rely on both the conservative elites and the conservative people in the periphery. They strengthened the social capital of Islamic orders, facilitating the diffusion of political power and control to the conservative society. After 2007, the JDP government allied with the Gulen Movement to strike back to the military. Many secular, Kemalist and Euroasianist military officials were purged from their positions through judicial trials (Eldem, 2017, pp. 179-180; Rodrik, 2011). In other words, they leveraged the struggle between the centre and the conservative periphery, gained support from the latter, secured their political power and re-structured the

\footnotetext{
${ }^{59}$ Esen and Gumuscu (2018) elaborately present how the JDP government is transferring resources and rents to the Anatolian bourgeoisie and the circle of loyal businessmen. The main transfer mechanisms are "public spending; privatization of state-owned enterprises (SOEs) and public goods; and transfer of private capital from disfavoured groups to privileged circles.
} 
dominant coalition. It should be noted that the JDP government gained a chance to secure the consolidated civil control of the military, but they just replaced the purged officials with the members of the Gulen movement, which later attempted to mount a military coup against the government. The conservative periphery took to the streets, just after the military coup on $15^{\text {th }}$ July, 2016, to demonstrate their support for Erdogan. Afterwards, the ordinary people in the periphery helped Erdogan to have the extraordinary authority to set up the one-man rule and for the conservative elites to foster unrivalled systematic rent creation.

Turkey has not been able to transition to an open-access order. On the contrary, the country has experienced a high degree of erosion in one of the two doorstep conditions, the rule of law based on impersonality, and consequently regressed to a relatively more fragile limitedaccess order. The Gezi Protests were a backlash of the secular periphery against such an erosion of order but failed (Yasli, 2014, pp. 197-200; Yörük, 2014).

In the second chapter, we questioned North's Violence and Social Orders that it ignores the reaction of the people in the periphery against the centre can be employed by a faction in the dominant coalition to improve its position. We have showed that the conservative periphery reacted against the negative effects of rent creation among secular elites and their exclusion from economic rents created for the periphery to keep their support. The conservative bourgeoisie and the JDP political elites leveraged their reaction to improve their position in the dominant coalition and generate more political power and economic rents. Neoliberal populism were combined with development interventions in the case of the SAR especially after 2008 to keep the electoral support high and secure the constant support of the bourgeoisie.

After corruption scandals were uncovered in December 2013, an intra-elite conflict between the Gulen Movement and the JDP government escalated. Erdogan started to feel insecure, fearing a coup or riot that could remove him from power (Yilmaz \& Bashirov, 2018), and accelerated instability and the establishment of the one-man rule (Yasli, 2014, p. 193). All this happened under Islamist conservatism and neoliberal restructuring and populism in the context of globalisation (Bozkurt, 2013), which has been sustained with the electoral support of the urban and rural poor (Yörük, 2014), on which the neoliberal state and Islamic charities bestowed financial aid or aid in kind to tackle poverty under the guise of Islamic solidarity.

Neo-liberalisation is, as asserted by Harvey (2007, p. 19), "a political project to re-establish the conditions for capital accumulation and to restore the power of economic elites." Though 
he examined the relationship between interventionist developmentalist states and clientelism in African countries in Markets and States in Africa, it should be noted that Bates has not addressed the relationship between neoliberal states and clientelism in his subsequent books concerning the political economy of development in less developed countries. As Karadag (2010) establishes, "the JDP [...] has followed the tight fiscal and monetary policy recommendations of the IMF to put an end to rampant cronyism and the overall rentier mentality which, supposedly, was a by-product of the country's statist tradition". Yet, the outcome was the clientelistic neoliberal state creating uncompetitive rents for elites.

In conclusion, the implementation of neoliberalism for the JDP government has played an important role for keeping political support from international actors but mostly from domestic actors.

\subsection{The Kurdish Question in the Era of the JDP Government and the Development Narrative}

We have discussed why neoliberal policies have been implemented by the JDP government. It will be argued hereafter that the combination of neoliberal policies with development interventions in agriculture is a product of the political competition between the JDP government, the military-bureaucracy and the Kurdish political movement. Until the June 2015 general election the JDP government had employed the development narrative, along with the introduction of cultural rights and democratic norms urged by the EU. It also allowed for democratic opening up towards the Kurdish question. The main rationale was that the development narrative would require the use of the developmental methods and tools devised by the government rather than the use of military methods that would grant the initiative to the military. Given that the wide acceptance of the military narrative had facilitated the establishment of a war-regime in the 1990s that had nearly turned political parties into puppets of the military, the development narrative prevented this. But the military narrative has merged with the development narrative again after the June 2015 general election, which coincided with the political control of territories west of Euphrates by Kurds in Syria. ${ }^{60}$

The JDP government leveraged the Kurdish question to increase its advantage in the political struggle. We shall argue that neoliberal policies were coupled with GAP-based agricultural

\footnotetext{
${ }^{60} \mathrm{We}$ should note that the political interplay has always been active between the JDP government and the military, the CHP and the ultranationalist the NMP about the Kurdish question, and the latter group generally used the military narrative and the nationalist discourse to box the JDP government into a corner by tapping into nationalist sentimentality of the Turkish-origin constituency.
} 
interventions to persuade the Kurdish bourgeoisie (including large landholders) to politically act in concert with the state and the government. The government also intended to obtain consent from Kurdish-origin citizens by creating employment, to consolidate the political support of Islamist Kurds, Turks and Arab-origin citizens through development investments and grants, and to make the Kurdish political movement bereft of a political base and have it abandoned its arms.

We shall now address two important theoretical issues. Recall that we discussed Ostrom and Ahn's studies $(2008 ; 2009)$ and Miedema's study (2010) about social capital in the third chapter. Our main inference was that ethnicity is an important factor imposing itself on a person's preferences and make them hard to change, and that in a highly polarised society a person's choice based on her individual preference is highly influenced by her ethnicity.

All the development interventions efforts in the SAR and the introduction of cultural rights and democratic openings have not resolved the Kurdish question, because of the strong Kurdish intra-ethnic social capital formed by Kurdish individuals in their daily lives. But all the interventions have re-constituted the Kurdish question, which have exaggerated the existing inter-ethnic social capital between the Kurdish political movement and the secular opponents who have been oppressed.

Increasing political participation by the Kurdish political movement in a relatively free environment helped them to extend their political reach from the region to the entire country. However, the state and government felt threatened, attempted to intimidate and coerce both groups, constrained their political participation, and drove Kurds back to regional politics again. This shows what Bates' argument lacks. To him, regional diversity creates different regional rationalities and shape political terrains and the use of power, and that regionalism based on regional rationalities impel the elites at the centre to coerce regional actors instead of cooperate with them (Bates, 2017, p. 117). To us, an excessively centralised state that restricts political participation through various means, such as intimidation, coercion, legal restrictions, forced people to concentrate on their regional diversities and politics, thereby hampering development.

\subsubsection{The Kurdish Question between 2001 and 2008}

After PKK leader Ocalan was arrested in Kenya in 1999, the top cadre declared a ceasefire and ordered their militants to retreat to North Iraq in order to remodel themselves as a political organisation (Gurcan, 2015). They intended to become a political party for the entire 
country rather than just for overwhelmingly Kurdish-populated regions. Ocalan (2001) defined the post-2000 period as "a process that we engaged in a democratic republic period, which means the reflection of the will of the people on the base of a democratic process" (p.170) and offered "freedom and the option of a democratic union" rather than separation (p.171). The PKK's top cadre welcomed his message and urged for the recognition of cultural rights, rather than attempting to found an independent Kurdistan (Yegen, 2011, p. 75). Subsequently, the PKK did innovatively espouse the idea of a united Kurdistan through democratic confederalism and the establishment of a democratic republic encompassing the whole of Turkey (Akkaya \& Jongerden, 2011). In December 1999, Turkey and the EU decided at the Helsinki Summit to initiate Turkey's candidateship process. This triggered further democratisation, somewhat relaxing constraints on political participation of Kurds: the capital punishment of Ocalan was turned into life sentence; the state of emergency which lasted for two decades was lifted and so was the ban on the use of the Kurdish language.

Intra-ethnic, inter-ethnic and linking Kurdish social capital have played a key role in the post2000 period. Kurds have formed a strong diaspora under many pro-Kurdish organisations, especially since the 1980s, deriving benefits from transnationalism and technological developments in communication to develop all the types of social capital (Curtis, 2005). They effectively interacted in diplomatic and public spheres (Kayhan Pusane, 2015) through different means and methods, such as face-to-face interactions, media, demonstrations, daily activism, etc. (Grojean, 2011, pp. 189-191) to justify the cause of the Kurdish political movement. In the nation states encompassing different parts of Kurdistan, the Kurdish political movement instituted a new, complex party line through organisational changes and ideological transformation with respect to the concept of democratic republic and confederalism (Akkaya \& Jongerden, 2011, pp. 147-148). These efforts were also continued in politics. The pro-Kurdish party, the Democratic People's Party, achieved 6.2\% of the votes in 2002, mostly from densely Kurdish-populated areas. The political support for the Kurdish movement could not be thwarted by the Turkish state, despite Ocalan's arrest. However, the rise of the autonomous political body in Iraqi Kurdistan pushed the PKK into uncertainty in political competition among Kurds (Akkaya \& Jongerden, 2011, p. 154).

The upshot of the Iraq War in 2003 shifted the attitude of the Turkish state. Three important developments were underlying this shift: the Kurdish regional government emerged in Iraq after the collapse of the Baath regime; the military-bureaucracy, which saw that the democratisation process was undermining their political power, increasingly became 
dissatisfied with the EU process and; the PKK resumed their attacks (Yegen, 2011, p. 76). While all of these factors were inciting national sentiment among Turks, it was greasing the wheels of the military in their political struggle against the JDP government. As for Kurds, hundreds of thousands risked being arrested or coerced, carrying posters of Ocalan and Kurdish flags during the Newroz ${ }^{61}$ demonstrations in 2005. The state defined them as pseudocitizens, threatening to cut financial assistance and social services and allowing nationalists to violate their human rights (Yegen, 2011, pp. 76-78). When the PKK's attacks peaked in 2007 and 2008, US officials and the General Staff agreed on intelligence cooperating, resulting in (futile) air strikes on the guerrilla bases in Northern Iraq. The PKK's attack of the Aktutun military border post with over 500 militants in October, 2008 resulted in hatred among ordinary Turks to the US because of perceived insufficient intelligence support. The General Staff lost credibility and political power, and a commission was set up in November 2008 between the US, the JDP government, Iraq and Kurdistan regional government in Iraq, bypassing the military-bureaucracy and military solutions (S. Y1lmaz, 2012).

The first constructive step to the Kurdish question taken by Erdogan was during the Diyarbakir meeting in 2005. While Turkish officials and academics with a more nationalist leaning had generally referred to the problem as "the terrorism problem" or "the Eastern problem", the recognition of the issue as the Kurdish question by Erdogan was a historical moment for Turkey (The Economist, 2005, April 18th). Apparently, the JDP's success in winning municipalities in some densely Kurdish-populated cities in the 2004 local election impelled him to initiate such an opening to increase its influence over Kurds and get their support in Erdogan's power struggle with the army commanders. Even the leader of the True Path Party, Mehmet Agar, who had served for the security-bureaucracy at the highest level in the struggle with the PKK in the 1990s, said, "let them do politics on the plain instead of holding arms in the mountain" (Küçükşahin, 2006, 8 October). Furthermore, the politics of rapprochement with Kurds within Middle East politics was adopted by the government in 2005, which resulted in close political and economic consultations with Mesud Barzani, the leader of the Kurdish regional government in Iraq, and in the first political consultations with Ocalan (S. Y1lmaz, 2012).

As a result of the 2007 general election and the aforementioned unsuccessful military operation against the PKK, the JDP and the Kurdish political movement became the two parties competing over political power in the SAR. State officials, therefore, felt obliged to

${ }^{61}$ Newroz is celebrated for the arrival of spring. 
support the JDP government against the Kurdish political movement. This indicated that the development narrative would prevail over the military narrative, especially after the military failed in the cross-border military operation to destroy the PKK's militants. This change was further supported by the EU approving in 2005 the start of negotiations for Turkey's access to the EU, which would bring financial and technical assistance to Turkey. As we shall see in Chapter 7, this assistance greatly helped the expansion of agro-industries and agricultural mechanisation in the SAR.

The intra-ethnic social capital of Kurds helped them to move beyond resisting the state. The relative unsuccessful result of the 2004 local election forced the Kurdish movement to reorganise their legal political network under the name of the Democratic Society Party (DTP in Turkish acronym). The party followed a new way to pass the $10 \%$ election threshold, nominating independent candidates in highly Kurdish-populated. They won 21 seats in parliament and formed a party group for the first time in the history of the Kurdish movement in Turkey. The key feature of the party was to advocate the theses of democratic autonomy in line with democratic confederalism ${ }^{62}$ (Akkaya \& Jongerden, 2011, p. 155) to debunk the accusation of being an ethnic political party (Kavak, 2012, pp. 153-157). The peripheral movement of Kurds targeted the excessive centralisation of the Turkish state, and adopted a democratic, local, decentralised, peaceful, leftist agenda, endorsing Turkey's access to the EU (Kavak, 2012, pp. 159-162). This proves our point that when the political participation of Kurds was allowed, they displayed a willingness to contribute to Turkey's political agenda instead of only focussing on regional politics.

The pro-Kurdish party won only one seat in the West SAR. In the East SAR, the JDP won 15 seats but the DTP 11 seats. Fierce competition in the region continued during the next elections. The JDP obtained votes from Turks and Arabs as well as Kurds. Many of those Kurds tend to support Islamic conservatism, others accorded with the state or the current political economic system in return for political economic benefits (Medyascope.tv, 2018, 23 March). More specifically, we can divide the Kurds in three categories: those who have limited educated and earn low incomes tend to vote for the existing pro-Kurdish party, as do those who are higher educated and earn relatively higher incomes; those who have limited education but earn relatively higher incomes tend to vote for the JDP (Medyascope.tv, 2018, 23 March). According to Kucukaydin (2013b, p. 138), the working class has a leading role in

\footnotetext{
62 Kurdistan includes territories in four nation states: Turkey, Iraq, Syria and Iran. Democratic confederalism requires the establishment of non-state-based self-governing bodies controlled by local communities.
} 
the Kurdish political movement whilst the Kurdish bourgeoisie is supposed to follow, and the conflicting interests of these classes both constrain and support the movement.

In fact, the JDP government agrees with the interests of the Kurdish bourgeoisie as the government represents the interest of the bourgeoisie. Given that large landholders, sheiks and tribal leaders have long got involved in capitalist accumulation, from Besikci's standpoint (1990, pp. 90-94), we can say that the Kurdish bourgeoisie, including urban capitalists, have long been collaborating with the state and incumbent governments. That is, they are a part of the dominant coalition. However, their position in it is far weaker than the Istanbul and Anatolian conservative bourgeoisies. As we discussed before, neoliberal policies helped the entire bourgeoisie, including the Kurdish one, to advance their capital accumulation. Development interventions would work in the same way, and the government, therefore, would be able to get the support of Kurdish capitalists.

When the JDP government used the development narrative to frame the Kurdish question, the Kurdish bourgeoisie gained in importance. That is, they are of importance as long as they can control the Kurdish peripheral movement with democratic requests and keep them within the boundaries of the current political economic order. In this context, as Kucukaydin (2013b, p. 138) points out, the political bases of the Islamist and the Kurdish movements are the working class people, but "the decisive factor avoiding their convergence is not class-based interests but their cultural and historical backgrounds". In other words, the dichotomy between Turkishness and Kurdishness has created different forms of intra-ethnic social capital whereas the dichotomy between Islamic conservatism and the political culture shaped by the interaction with leftism has created other forms of intra- and inter-ethnic social capital. Increasing political participation of Kurds could have removed these dichotomies, and induced the rise of class-based politics and radical democracy. As we shall see, whenever such an opportunity did raise, the state and the JDP government prevented it.

\subsubsection{The Kurdish Question between 2009 and 2013}

The 2007 general election and the presidential election results favoured the Islamist government. But the political contestation between the secular Kemalists and the JDP government carried over to the judiciary (Casier, Jongerden, \& Walker, 2015). While the Ergenekon and Sledgehammer trials, conducted by Gulenists in the police and the judiciary in order to purge Euroasianist and secular Kemalists, the secular establishment challenged the JDP government over the Kurdish Question. 
The JDP government - boosted in their confidence due to the result of the general election became more involved in the Middle East. Ahmet Davutoglu, the then minister of foreign affairs, was behind Turkey's international political shift. He had proposed in the Strategic Depth the international strategy that Turkey should follow. That is, Kemalist political elites had turned away from Turkey's historical and geo-cultural background and her central position to the Islamic civilisation and welcomed the West and its values. But the attempt to adopt the political-cultural system of the West had resulted in tension between political elites (or the centre) and the people (or the conservative periphery) (Davutoğlu, 2001, p. 83). To him, 'neither is Turkey a colony with a weak historical background, nor is she a pivotal country with a well-established political structure in the world system' (Davutoğlu, 2001, p. 83). In this sense, Turkey was to shift to Turk-Islamic values to overcome the tension, building a Sunni-Turk nation and forging a Sunni Islam axis in the Middle East under Turkey's leadership (Yasli, 2014, p. 166). This policy shift reflected itself in two immediate policy practices. The regional leadership in the Middle East was thought to be secured with the use of soft-power, especially in its relationship with Iraq and Syria (Yasli, 2014, p. 163). The national integrity was intended to be attained through solving the Kurdish Question by transforming Kurds into having an overriding Islamic identity instead of Kurdishness. However, the Kurdish movement, as stated before, is inherently a modern, secular movement linked with leftist ideologies, and therefore Islamic networks (i.e. Turkey's Hezbollah) and Barzani's political influence were used by the government to break the PKK's influence over Kurds (Yasli, 2014, pp. 163-164).

A series of events took place in Turkey associated with the previously described political terrain. The DTP won back local municipalities from the JDP in 2009. The Union of Communes in Kurdistan (KCK in Kurdish acronym) had been influencing the region politically and ideologically since 2007, which serves in all parts of Kurdistan for setting up "democratic republic", "democratic confederalism" and "democratic autonomy" (Casier et al., 2015) as checking Kurdish urban political elites who interact with the Kurdish bourgeoisie as a matter of urban politics (Kucukaydin, 2011, 20 November). Meanwhile, the PKK's attacks and urban protests of the Kurdish poor were continuing in the SAR, and some prominent members of the party cadre were detained by the police. A few months later, the government urged the opposition parties to support "the Kurdish opening". The alliance between Gulenists and the JDP government intended to disarm the PKK, criminalise Kurdish politicians, disorganise the $\mathrm{KCK}$, and weaken leftist national sentiments of Kurds and 
transform their political mindset by setting up a liberal-Islamist conservative party (Yasli, 2014, pp. 173-174) working closely with the relatively far weaker Kurdish bourgeoisie. Another element of the plan was to boost the regional development through the GAP investments (Casier et al., 2015). In other words, development interventions in agriculture was to a product of political plans of the JDP government.

As a part of the Kurdish opening, some guerrillas returned Turkey's territories to surrender as a goodwill gesture, enthusiastically welcomed by many Kurds. This led ordinary Turks and the opposition parties to accuse the government of treason and separatism (Gunter, 2013). The General Staff also bitterly repeated their commitment to the integrity of the nation and fight against terrorism (Hilton, Casier, \& Jongerden, 2009). The JDP government started to fear that they would lose their nationalist political base (Gunter, 2013), and retreated to 'a democratic opening' involving the democratisation of minority rights and freedom of religion and faith. Later they moved to a more backward position and launched 'a national unity project' against terrorism (Kökce, 2010, p. 135). The constitutional court stepped in and banned the DTP from politics. This was when the Peace and Democracy Party (BDP in Turkish acronym) was founded by the Kurdish movement. However, the state bureaucracy frequently tried to undermine the municipalities controlled by pro-Kurdish parties, and carried out KCK operations to disorganize the network of the Kurdish movement (Casier et al., 2015).

According to Kucukaydin (2011, 20 November); (2013, 4 August), all the operations and openings were conducted to help the Kurdish bourgeoisie to gain more control over the political movement. Recall that the Kurdish bourgeoisie has made their capital accumulation through benefits provided by the state, their economic relationships with the Turkish bourgeoisie and through investments in west Turkey. As a result, the intra-ethnic social capital of Kurds could not be dissolved, despite KCK arrests, an illegal organisation gaining support of the Kurdish poor (Kucukaydin, 2011, 20 November). The Kurdish opening came to an unsuccessful end. However, the government never ceased increasing public investments for agricultural development of the SAR; they kept their relationships with the Kurdish bourgeoisie; and development interventions continued.

\subsubsection{The Kurdish Question between 2013 and 2017}

When the Arab Spring started in the Middle-East in 2010, some Arab leaders governing secular regimes in the Middle East were overthrown. This historical period created political incentives for Erdogan's government to realise their plans for forging the Sunni axis under 
Turkey's leadership. They influenced the Muslim Brotherhood in Egypt through soft-power politics and implemented hard-power politics against Syria's secular regime by supporting Islamic militants in the civil war.

The most important event in the course of the Kurdish question occurred as the Syrian Army made a strategic move retreating from North Syria in the mid-2012. This allowed the Democratic Union Party, following Ocalan's political programme rather than Barzani's political vision, to set up democratic autonomy (Yasli, 2014, pp. 175-176). This political development impelled the JDP government to negotiate with Ocalan and other Kurdish political elites with the open support of Great Britain and the EU (Gunter, 2013), and eventually to declare a new peace process in early 2013. This was aimed to gain support of Kurds against the Shia axis in Iran and Iraq and to set up a federation including the region controlled by Barzani, who would agree with the US's interests (Yasli, 2014, pp. 177-180).

The Gezi protests in May-June, 2013 started several months after the peace process was initiated. Initially, Kurdish political elites took an ambiguous approach to the protests, fearing that a nationalist plot would end the peace process ("the Demirtas's Comment," 2013, 1 June; "the Ocalan's Message," 2013, 7 June).

The Kurdish political movement, understanding its political fault in the Gezi protests, then set up a new party, the Peoples' Democratic Party, embracing 'the spirit of the Gezi', including Turkish leftists, Alevis, environmentalists, feminists and LGBTs ${ }^{63}$ (Göksel \& Tekdemir, 2018) under the banner of 'becoming a part of Turkey', referring to the project of the democratic republic. In the election that choose Erdogan as president of Turkey, Selahattin Demirtas, the co-head of the pro-Kurdish party, obtained around $9.8 \%$ of the votes. The result was outstanding for the Kurdish movement in the June 2015 election; the newly founded party secured $13.1 \%$ of the votes, the highest in the history of the movement. Erdogan's administration had relaxed constraints over the political participation of Kurds to reach their political aims through the peace process. The moderate political environment had therefore facilitated the capability of Kurds in cementing their bridging social capital, which they had already forged with Turkish leftist parties and organisations under Peoples' Democratic Congress in 2011. All these efforts, coupled with the need for frustrating Erdogan's determination to replace the parliamentary system with an authoritarian presidential system, resulted in the JDP having lost ruling party status.

${ }^{63}$ The abbreviation of lesbian, gay, bisexual and transgender 
Erdogan's administration then waged a war against the Kurdish political movement after the election to restore his political power. According to Kucukaydin (2015, 9 November), he found political support in the military-bureaucracy, which was alarmed by the control of Tal Abyad by Kurdish guerrillas in Syria and the possible emergence of the Kurdish state. The urban warfare against Turkey's Kurds lasted a year, and state control over Kurdish-populated areas was restored eventually. When the military-bureaucracy recovered its political power relying on the military narrative, the military coup against Erdogan's administration was staged in 2016 by mainly Gulenists and other opponents. Since the failed coup, according to Ö. A. Çelik (January 8, 2019) conducting an interviewing with Ozgur Ozel, a prominent parliamentary member from the CHP, that there has existed an agreement between Erdogan's administration, the military-bureaucracy and the bourgeoisie. His administration allied with the military-bureaucracy to maintain the excessively centralised state depending on the one nation ideology, and with the bourgeoisie to provide them with clientelistic benefits with low legitimacy (Karaoğlu, 2018, 10 July).

\subsection{The Combination of Neoliberal Policies with the GAP-based Development Policies}

We now need to respond to the question why neoliberal economic policies have been combined with the GAP since 2001. The response should be focused on the development narrative of the Kurdish question, which matches with the GAP and GAP-related government interventions in the SAR's political and economic context. But why has the development narrative come to the fore since 2001? This is because the dichotomy of the political solution and the military solution to the Question emerged from the political struggle between the JDP government (or the Islamist social capital) and the military-bureaucracy on the national level. The promotion of the political solution underpinned by regional development interventions has been employed to keep the military bureaucracy away from politics as possible. On the regional level, the social capital of the Kurdish political movement were aimed to be dissolved. Neoliberal policies and development interventions were simultaneously used to attract the Kurdish bourgeoisie to ally with the government as well as ordinary Kurds to cut their ties with the Kurdish political movement.

The reason why neoliberal economic policies have been carried out is linked with the political struggle between the military-bureaucracy and the JDP government. Islamists acted flexible in 2001 and oriented their political programme with the interests of the different segments of the bourgeoisie (including Kurdish capitalists), the Western countries and international organisations. Neoliberal policies were a must to get political support and 
alienate the military-bureaucracy whilst neoliberal populism was useful to consolidate and expand the right-wing political base.

In the political course of the Kurdish Question, the development narrative has been exploited for Erdogan's internal and external political objectives. As Erdogan's government challenged the military-bureaucracy, they mostly kept the military away from the military options, which would otherwise have bestowed political power to the military. The development narrative of the question has offered him the required tools to shape the political terrain. In his political struggle with the military, Erdogan was required to lean on different segments of the bourgeoisie. Recall, the secular, westernised bourgeoisie withdrew their support from the military in favour of the JDP government, which applied neoliberal policies, thereby creating enormous economic benefits. Furthermore, the GAP as a multi-sectoral integrated project has been essential in generating economic benefits for capitalists from different ethnic groups in the SAR through governmental development interventions such as tax exemptions, selective credit mechanisms, financial incentive programmes, etc.

The development narrative of the Kurdish Question was a component of a grand strategy in the Middle East under the name of neo-Ottomanisation, aimed at the foundation of the federation of Turkey-Kurdistan governed by a centralised state structure (Karaoğlu, 2018, 10 July). The creation of interdependence between neighbouring countries by means of development was important in this context. The intention was to promote closer economic integration between the neighbouring countries and the SAR by establishing the cross-border trade, unlocking the industrial and agricultural potential of the SAR catalysed by the GAP. As Davutoglu states in the Strategic Depth, the creation of economically integrated areas including the SAR, North Syria and North Iraq (under Barzani's control), mostly populated by Kurds, was thought as an efficient way to isolate and eliminate the PKK and foster prosperity (Davutoğlu, 2001, pp. 146-147). The formulation of the solution for the Kurdish question has therefore rested on political and development contexts, sidelining the militarybureaucracy. The particular economic policy was effectively executed between Turkey, Iraq and Syria especially prior to the Syrian Civil war, creating economic benefits to the SAR (Müftüler-Baç, 2014; Ozer, 2007).

The development narrative and the GAP have been used for isolating the PKK. The then deputy prime minister, Cemil Cicek, said, 'security measures are not enough to avoid terrorism, an economic package is necessary [...]', and he added, 'if you say there is no economic package of this [Kurdish opening], the GAP is the economic package of it.'(Turkey 
Grand National Assembly, 2009, December 25, p. 69). As Orhan Miroglu, a Kurdish politician, reports in an interview that the nascent Kurdish bourgeoisie has inherently a classbased interest conflict with the PKK, thus neither willingly supports nor completely objects to it in fear of the coercive acts to be made by Turkish state (Basaran, 2011. 5 December). From this, the government attempted to more tightly control the Kurdish bourgeoisie with the GAP, using it as a fountain of privileges. Indeed, Miroglu contends that the Kurdish capitalists who collaborated with the state grew their economic and political power during the armed conflict (Basaran, 2011. 5 December). Obviously, development interventions are introduced to alienate the Kurdish capitalists from the PKK.

It was also envisaged that economic prosperity induced by the irrigation investments of the GAP could help the government to obtain political consent from ordinary Kurds. The discourse of democratisation was exploited to make them dream of security and prosperity. Meanwhile, it was thought that the political division between Barzani and the PKK could be used to impose Islamic identity on Kurds. However intra-ethnic social capital of Kurds has strengthened and followed their political agenda with their own networks and institutions.

\subsection{Conclusion}

In this analysis chapter, we addressed different but connected themes. We showed that the relationships between elites in the dominant coalition are not enough to comprehend state formations, and that the relationships between the centre and the periphery are of importance in understanding how intra-elite relationships change. This is what North et al (2009) do not recognise for the countries such as Turkey. When the JDP elites came to power, they attempted to involve the conservative and later the Kurds into the system, who had felt mistreated by the secular establishment. The existing level of impersonality has worsened over time. The consolidated control on military power has not been achieved as Gulenists and the JDP elites sought to exploit the capability of the military-bureaucracy to make their power incontestable. Even worse, the country declined to a relatively more fragile limited-access order with the deterioration of impersonality under an authoritarian regime. This increased discriminations and restrictions on Kurds' political participation. Favourable global liquidity gradually ended after 2013, and the country entered an economic slowdown on account of clientelistic economic relationships under the alliance between an excessively securityoriented group in the military and Erdogan.

Let us return to Bates and his argument that regional diversities leads to regionalism as a result of the political interplay with the incumbent political elites and regional elites. 
However, as Harris (2008) contends, discriminatory, coercive state practices over Kurds have triggered the PKK's violent reaction; the latter have subsequently generated state authority; cultural diversities have been formed by this conflict.

Apart from this, we saw that Kurds constituted a country-wide policy such as democratic republic and stepped forward to put it into practice under the rubric of "becoming part of Turkey" once the excessive centralised country eased political participation. It was displayed that international relations and dealings influenced the political economic development of the SAR, such as Turkey's plan over the Middle East and the development of a Kurdish state during the Syrian civil war. The latter drove the Turkish state to terminate the peace process and to wage a war against the Kurdish movement, which caused Kurds to pursue no longer "becoming part of Turkey".

Neoliberal policies with populism were applied by the JDP government to get support from the different sections of the bourgeoisie, international organisations and Western countries. Neoliberal clientelism has enabled the government to provide privileges and rents to the bourgeoisie and the conservative periphery in return of votes. The Kurdish bourgeoisie also benefitted from these possibilities to keep themselves align with the state policy. Public expenses, tax exemptions, grants and other financial incentives were increasingly granted after 2008 to Kurdish capitalists and agricultural enterprises through different programmes, particularly within the GAP. The combination of neoliberal policies with development interventions are mainly product of national and international political strategies and aims of the JDP government. 


\section{PART 2: NEOLIBERAL AGRICULTURAL POLICIES AND AGRICULTURAL DEVELOPMENT}

\section{Chapter 6: The Neoliberal Agricultural Transformation of Less Developed Countries}

\subsection{Introduction}

Until the 1980s, most developing countries had employed an inward-looking industrialisation model. As demonstrated before, increases in petroleum prices and contractions in export engendered international trade and budget deficits in the 1970s, and the resultant debt crisis in developing countries prompted serious criticism against the development models that had been pursued until then (Mudge, 2008). In particular, government interventions, political patronage and protectionism for industries were blamed by the proponents of the free market in the late-1970s for having created distortions that led to development failures (Weiss, 1993, pp. 26-41). The debt and development crisis triggered neoliberal policy interventions (conditionalities) in the 1990s.

The role of the IMF and the WB in the neoliberal economic order and the link between neoliberal economic policies and structural adjustment programmes will be discussed, and we will show how RCT has been established in politics and interacted with neoliberalism. This interaction is present in the structural adjustment programmes supervised by the IMF and the WB. Finally, we discuss how RCT approaches agricultural development and critically question the results of the neoliberal agricultural transformation in less developed countries. It is argued that the urban coalition - i.e. the bourgeoisie, professionals, state actors - has kept its power in the neoliberal era whereas urban workers were cast aside. Furthermore, many agricultural producers in the periphery were unable to adapt to the new policy climate.

\subsection{Neoliberalism and Neoliberal Economic Policies}

Neoliberalism is a somewhat vague term (Venugopal, 2015) and can refer to different concepts: a set of policies, a hegemonic project, an ideology, a governmental programme, etc. (Gilbert, 2013). Here, we mainly take neoliberalism as a set of policies.

According to Rodrik (2017, November), '[i]n broad terms, [neoliberalism] denotes a preference for markets over government, economic incentives over social or cultural norms, and private entrepreneurship over collective or community action.' As Mudge (2008) argues, neoliberalism has three faces including: an intellectual face, a bureaucratic face and a political face. Its intellectual face reflects the Anglo-American mindset accompanied with 
trans-nationality that gives importance to the market "as a source or arbiter of human freedoms", rejecting Keynesian and socialist state interventionism (Mudge, 2008). Its bureaucratic face can be characterised by "liberalization, deregulation, privatization, depoliticization $^{64}$ and monetarism", which require that the state facilitates "unfettered competition" by retreating back from the economic domain and even from public services such as education and health (Mudge, 2008). Finally, its political face is related to the politics focused on markets, which limits state authority and favours certain economic groups, such as companies and white-collar professionals (Mudge, 2008).

The pinnacle of neoliberalism - the Washington Consensus - perceives neoliberalism as a set of policies, such as: financial liberalisation, deregulation, privatisation, financial discipline to limit inflation, tax reform including broadening tax base and cutting marginal tax, trade liberalisation together with competitive exchange rates, and the elimination of restrictions over foreign direct investment together with securing property rights (Williamson, 1993). In this sense, criticism of neoliberal policies in the 1990s generally focused on their potential risks to create further economic crises (Harvey, 2007, pp. 94-97; Stiglitz \& Schoenfelder, 2003; Toussaint, 1999, pp. 191, 222-226), their political-economic costs for the poor, leading to further inequality (Harvey, 2007, pp. 70-71; Huber \& Solt, 2004; Toussaint, 1999, pp. 142$146,194)$, and socio-economic implications of the state retracting from economic areas and public services (Harvey, 2007, pp. 163-164; Toussaint, 1999, pp. 141-142) ${ }^{65}$ Williamson (2004), however, blames developing countries, the IMF and the WB for not properly adhering to the set of policies stipulated under the Washington Consensus.

Unsustainable political economic costs of neoliberal economic policies, as well as the emergence of economic crises in the second half of the $1990 \mathrm{~s}$, brought modifications to neoliberal economic policies. ${ }^{66}$ Strong critique from intellectuals and disadvantaged socioeconomic groups, however, did not result in the abandonment of the Washington Consensus. Rather, transparency, good governance and competition-enhancing policies, the

\footnotetext{
${ }^{64}$ It entails "the separation of regulatory authority from the executive branch" and the insulation of "regulatory authorities from political influence" (Mudge, 2008).

65 The main reason for intensifying criticism stemmed from the results of neoliberal policies in developing countries. In the 1990s, transition economies could not recover "the deep and prolonged collapse" in their output after the socialist period; Sub-Saharan African economies could not increase by leaps and bounds despite all the structural reforms and international aid; economies of Latin America, East Asia, Russia and Turkey seriously crashed at unexpected times (Rodrik, 2006).

${ }^{66}$ For example, the Mexican crisis occurred in 1995-1996, The Argentine Great Depression between 1998 and 2002, The Russian financial crisis in 1998, the Asian financial crisis in 1997-1998.
} 
establishment of strong financial institutions, and improved safety nets to tackle poverty were added to the list of neoliberal policies (Stiglitz, 2007).

The IMF and the WB have always played an important role in supervising whether developing countries exercise neoliberal policies correctly (Williamson, 2004) and embrace the required policies to repay their restructured debts (Busch, 2010). Briefly, the important tasks of the WB are to assist the IMF by giving recommendations to developing countries and to conduct research to develop a theoretical framework to undergird neoliberal policies (Toussaint, 2008, pp. 168-175). The latter was essential in introducing good governance, poverty reduction and sustainability to counter various criticisms levelled against neoliberal policies in the 1990s. It is worth noting that the relationship between the IMF and the WB changed after the 1994 Mexican crisis. The IMF possessed more control than the WB over shaping governmental policies of debtor countries under stabilisation (short-term) or structural adjustment programmes (see Table 6.1) (Toussaint, 1999, p. 135), which is believed to help them stabilise their balance of payments and achieve steady economic growth (Killick, 2003, pp. 18-21). To sum up, there has always existed a link between neoliberal economic policies and structural adjustment programmes or IMF programmes.

Have neoliberal economic policies or IMF programmes been successful for less developed countries? A set of methodological problems make it difficult to evaluate the effects of IMF programmes on an economy. There are many other factors stimulating or hindering an economy such as other finance programmes and aid granted to less developed countries (Killick, 2003, p. 37). Despite all this, Bird and Rowlands (2017) draw the conclusion that IMF programmes have generally not promoted economic growth in less developed countries. They do however have some positive effects on economic growth of low-income countries in the subsequent two years following the signing of an agreement with the IMF (Bird \& Rowlands, 2017). According to Killick's study (2003, pp. 67-71), whilst IMF programmes have made substantial improvements on the balance of payments accounts of the countries, most of them have produced either minor positive effects or negative effects on inflation rates over the longer term. 


\begin{tabular}{|c|c|c|c|}
\hline \multicolumn{2}{|c|}{ The First Phase: Short-Term Macroeconomic Stabilis ation } & \multicolumn{2}{|c|}{ The Second Phase: Structural Reforms } \\
\hline Policies & Aims & Policies & Aims \\
\hline $\begin{array}{l}\text { Devaluation and the } \\
\text { creation of a uniform } \\
\text { exchange rate }\end{array}$ & $\begin{array}{l}\text { *Paying real prices to direct producers } \\
\text { *Helping export-oriented sectors become more } \\
\text { competitive and increase their revenues }\end{array}$ & Trade liberalisation & $\begin{array}{l}\text { *Making the national economy } \\
\text { more competitive }\end{array}$ \\
\hline $\begin{array}{l}\text { Reductions in } \\
\text { budget deficits }\end{array}$ & $\begin{array}{l}\text { *Alleviating inflationary effects of public } \\
\text { spending } \\
\text { *Accumulating surplus for repayments of debts }\end{array}$ & $\begin{array}{l}\text { Liberalisation of the } \\
\text { banking system }\end{array}$ & $\begin{array}{l}\text { *Setting interest rates on the free market to } \\
\text { improve the allocation of financial resources } \\
\text { *Increasing domestic savings and attracting } \\
\text { foreign financial resources }\end{array}$ \\
\hline $\begin{array}{l}\text { Price liberalisation by } \\
\text { terminating subsidies } \\
\text { and price controls }\end{array}$ & $\begin{array}{l}\text { *Letting market mechanism set the real price } \\
\text { for efficient resource allocation }\end{array}$ & $\begin{array}{l}\text { Privatisation of } \\
\text { state-owned firms }\end{array}$ & $\begin{array}{l}\text { *Decreasing budget deficits stemming from } \\
\text { high duty losses } \\
\text { *Increasing economic efficieny of the firms } \\
\text { privatised }\end{array}$ \\
\hline $\begin{array}{l}\text { Setting prices of oil } \\
\text { products and public } \\
\text { services }\end{array}$ & $\begin{array}{l}\text { *Increasing public revenues } \\
\text { *Decreasing budget deficits }\end{array}$ & Tax reform & $\begin{array}{l}\text { *Expanding the tax base and increasing public } \\
\text { revenues } \\
\text { *Improving the allocation of economic } \\
\text { resources }\end{array}$ \\
\hline \multirow[t]{6}{*}{$\begin{array}{l}\text { De-indexation of } \\
\text { salaries }\end{array}$} & $\begin{array}{l}\text { *Decreasing public expenditures and } \\
\text { inflationary effects }\end{array}$ & Land privatisation & $\begin{array}{l}\text { *Raising public revenues } \\
\text { *Benefitting from scale of economies by selling } \\
\text { lands to large landholders and investors }\end{array}$ \\
\hline & & $\begin{array}{l}\text { Relaxing labour } \\
\text { market regulations }\end{array}$ & $\begin{array}{l}\text { *Increasing labour mobility to deal with } \\
\text { unemployment }\end{array}$ \\
\hline & & Reforms in trade unions & $\begin{array}{l}\text { *Improving income distribution by eliminating } \\
\text { privileges as far as possible that comes from } \\
\text { political power of trade unions }\end{array}$ \\
\hline & & $\begin{array}{l}\text { Reforms in } \\
\text { pension systems }\end{array}$ & $\begin{array}{l}\text { *Using pension funds effectively by turning } \\
\text { them from public into private one. }\end{array}$ \\
\hline & & $\begin{array}{l}\text { Poverty and } \\
\text { social safety nets }\end{array}$ & $\begin{array}{l}\text { *Managing poverty } \\
\text { *Alleviating adverse effects of contractions in } \\
\text { social public expenditures }\end{array}$ \\
\hline & & Good governance & $\begin{array}{l}\text { *Keeping the management of economy away } \\
\text { from political considerations }\end{array}$ \\
\hline
\end{tabular}

Table 6.1 Main Policies and Aims of a Typical Structural Adjustment Programme (Killick, 2003, pp. 25-26; Toussaint, 1999, pp. 140-150)

If we compare the period of 1961-1981to 1981-2016 in terms of economic growth (Table 6.2), the world and low and middle-income countries enjoyed lower average GDP (and per capita) growth rates in the neoliberal period. 


\begin{tabular}{|c|c|c|c|c|}
\hline \multirow{2}{*}{\begin{tabular}{c} 
Country Groups \\
\cline { 2 - 5 }
\end{tabular}} & \multicolumn{2}{|c|}{$\begin{array}{c}\text { Average Growth Rate of } \\
\text { Gross Domestic Product (\%) }\end{array}$} & \multicolumn{2}{c|}{$\begin{array}{c}\text { Average Growth Rate } \\
\text { of Per Capita Income (\%) }\end{array}$} \\
\hline & $1961-1981$ & $1981-2016$ & $1961-1981$ & $1981-2016$ \\
\hline Low \& middle income countries & 5.36 & 4.15 & 2.93 & 2.54 \\
\hline Low income countries & N/A & 3.43 & N/A & 0.70 \\
\hline Middle income countries & 5.42 & 4.20 & 3.18 & 2.66 \\
\hline Lower middle income countries & 4.53 & 4.45 & 2.03 & 2.57 \\
\hline Upper middle income countries & 5.72 & 4.07 & 3.45 & 2.97 \\
\hline World & 4.67 & 2.84 & 2.57 & 1.43 \\
\hline
\end{tabular}

Table 6.2 Average Growth Rates of Gross Domestic Product and Per Capita Income of Income Country Groups and the World as a Whole (The World Bank, 2017)

Examining the experiences of Latin American countries from 1982 to 1995 that were supervised by the IMF, Huber and Solt (2004) find that 'higher levels of liberalisation and more radical processes of liberalisation are associated with high levels of inequality and poverty.' More importantly, it appears that deviations from market fundamentalism have turned out well on the other side of the world. China, India and several other Asian countries have made significant inroads in alleviating poverty since the 1990s by adapting themselves to the market but deviating from neoliberal premises through a high level of trade protection, limited privatisation and interventionist industrial policies (Rodrik, 2006).

Toussaint (1999, pp. 140-150) claims that the neoliberal policies in a structural adjustment programme generally impose high socio-economic burdens on ordinary households, the working class and small producers and favour wealthy people. IMF programmes are therefore politically costly for politicians, but they have to implement them to be able to access shortterm loans from international creditors to recover their economy (Toussaint, 1999, p. 136).

Still, it is safe to state that neoliberalism has not enabled developing countries to develop their economies to a desired level. The foremost reason is that neoliberalism provides a single set of solutions that has proved to be unsuccessful in development (Rodrik, 2017, November; Stiglitz, 2007), especially in a context of "hyper-globalisation” (Rodrik, 2017, November). Policies designed within a local context and carried out with government interventions adaptive to changes - such as happened in many East Asian countries, are most likely to produce the desired results (Rodrik, 2017, November; Stiglitz, 1996, 2007). Another reason is that both rapid liberalisation and excessive protectionism do not create economic growth in developing countries (Stiglitz, 2007). 


\subsection{Rational Choice Theory and Its Links with Neoliberalism}

This section briefly depicts the link between neoliberalism and RCT to better understand the effects of neoliberal policies in agriculture.

Given its relationship with neoclassical economics, RCT is an important theoretical source of neoliberalism, with the conception of individuals as utility maximizers (Becchio \& Leghissa, 2017, pp. 12, 17). RCT rests on the assumption that individuals act rationally, thus maximizing their expected utility function. This logic is followed when moving from the individual to the social level, that is, a society can enhance its welfare by maximizing the social utility function (Becchio \& Leghissa, 2017, p. 113).

$[\mathrm{N}]$ eoliberalism is the use of maximization as the general rule to get any rational outcome in any framework. Choice involves means; ends are given, and they are not questionable. Individuals, social groups, institutions which are able to follow this way of choosing are bound to get the most rational possible result (benefit) and, simultaneously, to get it by the minimization of effort (cost) (Becchio \& Leghissa, 2017, p. 114).

Those who first sought to use RCT in politics accepted the conception of neoclassical economics that an individual seeks to maximize his political interests in a political domain, as he does in a market for his utility maximization (Buchanan \& Tullock, 1962, pp. 17-20). According to Buchanan and Tullock's (1962, p. 20): '[...] the representative or the average individual acts on the basis of the same over-all value scale when he participates in market activity and in political activity'. Espousing this idea, Becker (1986, p. 109) claims, '[...] the economic approach is uniquely powerful because it can integrate a wide range of human behaviour', and adds, '[r]ather, all human behaviour can be viewed as involving participants who maximize their utility from a stable set of preferences and accumulate an optimal amount of information and other inputs in a variety of markets.' After acknowledging that people have different opinions about what is morally correct, and that there is no prospect of having a consensus among people in this sense, Tullock (1976, p. 5) says, '[v]oters and customers are essentially the same people', and maintains: '[t]here is no strong reason to believe his behaviour is radically different in the two environments [in the supermarket and the voting booth]. We assume that in both he will choose the product or candidate he thinks is the best bargain for him.'

Bates (2005, p. 2), in "Markets and States in Tropical Africa”, contradicts the generally accepted assumption of agricultural economists that an economic man is rational, but a government policymaker is incapable or corrupt. He indeed proves throughout his book that 
politicians too seek to maximise their political interest. In this regard, his analysis as to why Africa had failed in development until 1980, are self-explanatory:

$[\ldots]$ political action is purposeful behaviour, and $[\ldots]$ among the major purposes of government are the pursuit of certain social objectives and the resources needed to achieve them. Foremost among the social objectives of government in the developing areas is to shift the basis of their economies away from the production of agricultural commodities and toward the production of manufactured goods. [...] they set prices in markets in order to capture resources [and foreign exchange] from agriculture. [...] we also recognise that more personal motives animate political choices. Governments want to stay in power. They must appease powerful interests. And people turn to political action to secure special advantages- rewards they are unable to secure by competing in the marketplace. [...] For to secure any given objective, governments can choose from a variety of techniques. [...] they find project-based policies politically more useful [than pricing policies] [...], or they can subsidise the costs of farm implements $[\ldots]$ because of superior political attractions. [...] Agriculture in Africa is [...] taxed. [...] To increase output, governments finance production programs. But doing so, they introduce characteristic distortions (Bates, 2005, pp. 3-5).

Thus, government interventions produce market distortions, resulting in development failure. E. Ostrom (2010a) underlines by referring to Alchian's study (1950) that 'what is called "rational choice theory" [italic in original], is not a broad theory of human behaviour but rather a useful model [italic in original] to predict behaviour in a particular situation - a highly competitive market for private goods.', and she adds, "[t]his model of the [rational] individual has fruitfully generated useful and empirically validated predictions about the results of exchange transactions related to goods with specific attributes in a competitive market but not in a diversity of social dilemmas.'

The appropriation of common pool resource gives rise to a social dilemma among its users, such as the tragedy of the commons ${ }^{67}$. According to the seminal work, Governing the Commons, government interventions could cause a positive effect on collective action in appropriating a common pool resource productively and sustainably by adjusting the set of incentives to shape their acts over it and solving the problem of incomplete information with low costs (E. Ostrom, 2011, pp. 138-160-161).

\footnotetext{
${ }^{67}$ The tragedy of the commons is a term used in social science to describe the depletion or degradation of common pool resource caused by users who strive to maximise their benefits but not to cooperate to sustain it.
} 
Nevertheless, government interventions are considered in RCT as likely to produce failures and to lead the economy to achieve a less than Pareto optimal state ${ }^{68}$ under competitive markets, in which private goods are exchanged (Krueger, 1990). This is because noncompetitive rent-seeking takes place, associated with differing interests of private beneficiaries, bureaucrats and politicians (Krueger, 1990; Moore, 1990) and because of market distortions created by public policies. Such evaluations made by RCT scholars were called into play by the IMF and the WB in designing structural adjustment programmes after 1980 (Stein, 1992). In particular, arguments about the crisis of African agriculture in Market and States in Tropical Africa by Robert Bates were readily accepted by the WB (Leys, 1996). The main aim was to dilute the adverse effects created by politicians on determining policies and development outcomes (Leys, 1996).

\subsection{Rational Choice Theory and Neoliberal Policies in Agriculture}

Our main purpose is to show how neoliberal policies have been applied to the agricultural sector of developing countries. We focus on two questions. How does RCT approach government interventions in agriculture? And how have neoliberal economic policies and structural adjustment programmes affected agriculture of developing countries, according to RCT opponents?

Prior to the late 1970 s debt crisis that led to a dramatic change in economic policies, the main problem of many less developed countries (according to Bates) were the intentionally created distortions and inefficiencies in markets. But politicians had not acted irrationally in doing so; in effect, they sought to consolidate their power and squeeze agricultural surplus to aid industrialisation after independence. They acted rationally, establishing coalitions with bureaucrats, industrialists and manufacturers, urban dwellers, and rural elites, based on mutual interests, but to the detriment of small-scale producers (Bates, 2005, pp. 11-12, 14).

Two policies were adopted to appropriate agricultural surplus from cash crop producers. The marketing boards with monopsony power, which had been inherited from the colonial powers, were used for controlling the export of cash crops and diverting the accumulated foreign exchange to industrial development projects, which was never paid the boards back. The execution of this policy was conditional upon another policy: the low-priced crop policy (Bates, 2005, pp. 12, 15-18). In addition to being protected against global competition, local

\footnotetext{
${ }^{68}$ Pareto optimality/efficiency states that, "[a] given economic arrangement is [Pareto] efficient if there can be no rearrangement which will leave someone better off without worsening the position of others (Musgrave \& Musgrave, 1989, p. 60)."
} 
industries benefitted from purchasing raw materials at (artificial) lower prices than global market prices. Nevertheless, these industries generally proved to be unproductive due to failures in both design and operation (Bates, 2005, pp. 20-26, 62-70).

As for food crops, the low-price policy was of importance for the government to consolidate the political coalition with industrialists, and urban workers and consumers. Bates $(2005, \mathrm{p}$. 30) elaborates:

Political pressures for low-cost food come from two main sources. One, of course, is the urban worker. The other is the employer, who, when his workers are faced with high-cost food, is forced to pay higher wages. For political reasons, African governments must appease the urban worker; but as major employers and as the sponsors of industry, governments share the interests of those who pay the wage bill. To appease consumers while pursuing their own interests, governments therefore join with workers and industry in seeking low-cost food (p.30). [...] Not only have consumer interests remained militant; government have remained vulnerable to consumer disaffection (p.31). [...] And, hungry for capital to promote further investments, many governments strive to maintain an attractive environment for foreign investors. For all of these reasons, governments in Africa tend to resist demands for higher wages [...] (p.32). [They] aimed at reducing the cost of living, and in particular the cost of food. Agricultural policy thus becomes a byproduct of political relations between governments and their urban constituents (p.33). [However], [w] here the elite engages in the production of a food item, policies are not employed to depress its price (p. 43).

Reinforcing the policy of low-cost food, import of food was facilitated through several measures, such as overvalued exchange rates and a low level of protective tariffs. A ban on the export of food and the administrative control over food prices through marketing boards with monopsony power were also put into practice (Bates, 2005, pp. 35-39). The latter resulted in financial pressure on public budgets and corruption. ${ }^{69}$ Even when agricultural supply fell due to low-price crop policy, governments subsidised agricultural production and imported food but did not offer higher crop prices to agricultural producers.(Bates, 1983, pp. 112, 119-120). Consequently, agricultural producers carried all the economic burden imposed by the political coalition between the government and the bureaucracy.

\footnotetext{
${ }^{69}$ Local branches of marketing boards were staffed but rising costs of growing staff members and inefficiency in marketing operations compounded the financial pressure on public budgets (Bates, 2005, pp. 26-27). Furthermore, some officials perverted their power to increase their personal wealth allowing farmers to evade the policies in exchange for bribes (Bates, 2005, pp. 27, 42-43).
} 
The necessity of augmenting food supplies to appease urban elements of the coalition directed the government to ally with the rural elites, who were more inclined to lobby their interests than smallholders. Commanding a domestic food market that had dispersed throughout a country was far more difficult than controlling the export of cash crops, which passed through ports where transactions and rules could easily be monitored and enforced. Adding to this challenge facing the central government was the above mentioned corruption among officials who were bribed by farmers. This ultimately forced governments to implement different policies to boost food production and keep food prices low. First, they directly engaged in it begetting heavy economic losses and debts (Bates, 2005, pp. 46-47). Second, they supported farm schemes and irrigation projects that 'tend[ed] to be privately profitable for those fortunate enough to gain access to them', namely, rural elites (Bates, 2005, p. 48). Finally, governments subsidised inputs, imported through overvalued exchange rate and sold at administratively supported prices, rather than raising food prices. Again, this policy benefitted rural elites (rather than smallholders) who were more engaged in modern agriculture (Bates, 2005, pp. 49-56).

'The governments want[ed] cheaper food; they therefore lower[ed] the prices offered to producers. But such a measure only create[d] shortfalls in supplies and shortages result[ed] in higher prices' (Bates, 1983, p. 120). From the perspective of RCT, they created market distortions, generated "non-competitive rents" and resultant economic inefficiencies that directly thwarted improvements in social welfare. However, politicians reached their own political goal: the preclusion of possible political challenges from organised interests (Bates, 1983, pp. 120-122). The problem of small-scale agricultural producers is that they are unable to organize and take collective action to receive higher prices from the government, despite representing large in numbers (Bates, 1983). Consequently, they were doomed to pay higher prices for industrial goods but receive low prices for what they produce (Bates, 2005, p. 81).

Some nuance is necessary here. When the main political support base of governments was in rural areas, or the agricultural marketing systems rested on farmers' associations, favourable prices were likely granted to farmers. But if the government and the marketing system of a country relied on the urban constituency and commercial interests (the small and large-scale bourgeoisie), lower prices than global market prices were probably conferred on farmers (Bates, 1983, p. 113).

As for the structure of production in agriculture, when small-scale production prevailed in agricultural sector, as in the case of the cultivation of coffee and tea, governments were 
inclined to offer less favourable prices to farmers. When large-scale agricultural enterprises dominated in the cultivation of a crop such as rice, wheat, cotton, etc., they were more able to demand favourable prices (Bates, 1983, p. 114).

The structure of the industry matters as well. When local processing industries overwhelmingly depended on locally produced agricultural raw materials, thus using a large portion of the agricultural output, lower prices were possibly offered by governments to farmers to guarantee the supply of raw materials to those industries (Bates, 1983, p. 114). However, it was possible for farmers to receive better prices from government agencies through their electoral power when the local industry consisted of large-scale processors (Bates, 2005, pp. 86-87).

Generally, African governments allied with industrial capitalists, and this powerful coalition did not allow farmers to participate in decision-making processes. Where rural populations had generally predominated in less developed countries before 1980, the coercive power of states was a major threat for the farmers in the political periphery when resisting against the unfavourable policies. Oppositions were repressed, arrested and exterminated for "reasons of state" (Bates, 2005, pp. 81,106-107). As Bates (1983, p. 131) accepts, 'the end result of [such policies] has been the neutralization of the majority of the African citizenry', and continues, ' $[\mathrm{t}]$ his form of politics [...] could only be expected in the absence of meaningful party competition'. This is evident in the case of Turkey after transitioning to a multi-party system in 1950. The Democrat Party offered agricultural producers higher prices, guaranteed purchasing crops, and provide input and credit subsidies (Aydemir, 2000, pp. 218-219; Başkaya, 1991, p. 173; Keyder, 1979, p. 57; Robinson, 1952) in order to expand its political base and hold the power.

The most important element of the urban coalition is the domestic and foreign commercial and industrial bourgeoisie in Bates's analysis. Farmers were generally repressed in order to cater to the interests of the industrial bourgeoisie. Even when low-priced food was provided to urban workers, the main purpose was to alleviate the pressure of salary to be paid by the industrial bourgeoisie. The commercial bourgeoisie - backing the ruling party - was granted licences to import goods, and rents created by public policies were unfairly appropriated by the bureaucracy (Bates, 2005, pp. 101- 105). In return, doomed to economic havoc because of unfavourable policies, farmers sought alternatives and averted direct challenge against the excessive central power. For example, they cut back higher value-added cash crop production, changed their production mix in a manner that would inhibit specialisation in 
production, migrated to become urban workers in order to maintain their average income levels and sold their crops on the black market (Bates, 2005, pp. 80-86). As witnessed later, neoliberal policies and the third wave of democratisation nevertheless shook the central power of most less developed countries. African states collapsed and lost their control over rural areas; triggering violence rather than allowing for democratic participation of the periphery.

\subsection{The Critical Appraisal of Rational Choice Theory and Neoliberal Agricultural Policies}

As Polanyi (1945, p. 13) argued in Origins of Our Time: Great Transformation, 'the idea of self-adjusting market implied a stark utopia. Such an institution could not exist for any length of time without annihilating the human and natural substance of society', and 'inevitably, society took measures to protect itself'. He further argued that the state itself established the market by its purposeful actions such as monitoring, controlling and regulating it (1945, pp. $82-90)$.

Pointing out that the underlying factor behind economic crises in the 1970s was governmental interventions, the fervent market-oriented ideas may appear rightful in their complete termination. However, Bienefeld (1988) criticises such views as they deem government interventions completely harmful:

"[The micro economic evidence of the new orthodoxy] consists of a seemingly endless catalogue of 'failed' projects or sectoral 'disasters" ${ }^{\text {, }}$, in which the state is said to have played a significant role. Although this catalogue contains many deplorable cases, it cannot be used to support the orthodoxy's general conclusion. In fact this evidence only serves to knock down a quite absurd straw man who allegedly argues that any type of economic intervention by any sort of state is desirable."71

He contends that newly industrialised countries in Asia such as Taiwan and South Korea reached a substantial degree of economic development by applying highly interventionist policies in production, capital markets, trade, and research and development in line with their highly coherent national long-term economic policies. In this general policy framework, they successfully intervened in agriculture to augment agricultural productivity and rural income

\footnotetext{
${ }^{70}$ Bates (2005, pp. 20-26, 56-61) does the same in Markets and States in Tropical Africa, showing how African states failed in their interventions in agriculture and industry.

${ }^{71}$ Bienefeld (1988) made a reference to the World Development Report published by the WB, which emphasises that "[t]he key factor determining the efficiency of an enterprise is not whether it is publicly or privately owned, but how it is managed" (The World Bank, 1983).
} 
levels (Bienefeld, 1988). China has adopted market-oriented policies in agriculture but applied them with both government interventions and "unfamiliar institutional arrangements" interacting with local context (Rodrik, 2017, November). For example, the so-called household responsibility system that allows farmers to only rent agricultural lands for a long time period, rather than possess as property, have altered incentives, encouraged farmers in production for markets without the need for privatisation, and resulted in substantial success in agricultural productivity (Huang \& Yang, 2017). Apart from income support, price intervention programmes are introduced, removed or adjusted with regard to crop types, changing conditions of international markets and national targets in order to raise rural income levels and ensure agricultural security; input subsidies are implemented for bolstering innovative input use to raise agricultural productivity; public investments are made in research and development (Huang \& Yang, 2017). We can conclude that state interventionism can function well if the local context is taken into account in design.

As shown in Table 6.3, the average growth rate of China's agriculture is $4.56 \%$ annually since 1981 (The World Bank, 2017). Apparently, South-east Asian countries can largely converge on crafting their agricultural policies to secure development and food security through interventions along with high interaction with international markets (de Koninck \& Rousseau, 2013; OECD \& FAO, 2017, pp. 73, 77-80). It seems that many of them are more or less successful as China (D. J. Green \& Vokes, 1997), despite any neoliberal criticism pointing to emergent market distortions, lack of private banks in the sector and ambiguity in property rights (OECD \& FAO, 2017, pp. 71-75, 91). The Philippines is relatively the most unsuccessful country because of agricultural liberalisation that resulted in low growth rates (Paderon, 2005 cited in Connell \& Dados, 2014) and smallholders leaving their lands due to soaring influx of imported crops and losses in livelihood (CETIM, 2000). Note that the same data (The World Bank, 2017) also exhibits Turkey's average agricultural growth rate has only been $0.05 \%$ in the neoliberal period, which means that the neoliberal agricultural transformation has not met expectations in Turkey's agriculture. 


\begin{tabular}{|c|c|}
\hline East Asian Countries & Average Agricultural Growth Rate (\%) \\
\hline China & 4.56 \\
\hline South Korea & 2.20 \\
\hline Indonesia & 3.20 \\
\hline Malaysia & 2.25 \\
\hline Thailand & 2.45 \\
\hline Vietnam & 3.47 \\
\hline Myanmar & 5.18 \\
\hline Cambodia & 3.90 \\
\hline Laos & 3.27 \\
\hline Philippinnes & 1.90 \\
\hline
\end{tabular}

Table 6.3 Growth Rates of Agricultural Value Added in East Asian Countries between 1981 and 2016 (The World Bank, 2017) ${ }^{72}$

Table 6.4 compares various regions in terms of agricultural growth rates starting from 1981. Sub-Saharan African countries as a whole have somewhat outperformed East Asian countries in agriculture. Yet, there are wide differences in agricultural performance among SubSaharan African countries (unlike their East Asian counterparts). For example, Kenya's agricultural growth rate is $0.16 \%$ annually in the neoliberal period whereas that rate stands at $4.00 \%$ for Malawi.

However, South- East Asian countries grew their economies far more than Sub-Saharan countries in the period of 1960-2006. The main factor behind this success is that they have intervened in rural and agricultural development especially through pro-poor and pro-rural policies, later mediated by markets (Kees, David, \& Peter, 2012). The assisting policies have consisted of linking industrial development with agricultural development, enhancing farmers' orientation towards market by giving them more freedom in their economic activities $^{73}$, granting them credit, fertilizer and seed subsidies, applying effective price interventions and restricting export of food crops (Kees et al., 2012).

\footnotetext{
72 The data provided by the WB has some deficits for some years. For example, the relevant data of Cambodia was started to be shared with the WB in 1994. Apart from this, we accept that the year of 1981 roughly represents the beginning of the neoliberal period in developing countries.

${ }^{73}$ The fact that they have helped smallholders enter into market relations more freely must not be 'interpreted as an argument for laissez faire or the minimisation of state intervention'. It has been just offered within the context of state-led rural development, and thus market just function as supportive (Kees et al., 2012).
} 


\begin{tabular}{|c|c|}
\hline Regions & $\begin{array}{c}\text { Average Agricultural } \\
\text { Growth Rate (\%) }\end{array}$ \\
\hline Latin America \& Caribbean & 2.34 \\
\hline Middle East \& North Africa & 3.51 \\
\hline Sub-Saharan Africa & 3.79 \\
\hline South Asia & 3.17 \\
\hline East Asia \& Pacific & 3.53 \\
\hline $\begin{array}{c}\text { Europe \& Central Asia } \\
\text { (excluding high income countries) }\end{array}$ & 0.87 \\
\hline
\end{tabular}

Table 6.4 The Comparison between Various Regions as to Agricultural Growth Rates in the Period between 1981 and 2016 (The World Bank, 2017) ${ }^{74}$

Apart from relatively lower agricultural growth rates, neoliberal policies included in structural adjust programmes also led to de-industrialisation ${ }^{75}$. This is evident in African countries (Stein, 1992) though average growth rates of agriculture $(3.79 \%)$ in Sub-Saharan Africa has been relatively high since 1981 (The World Bank, 2017). In light of poor data quality, Jalilian and Weiss (2000) conclude that seven out of sixteen countries in Africa have experienced a degree of de-industrialisation, which implied a partial negative process in manufacturing. Given that the first phases of industrialisation are associated with processing agricultural raw materials, policy solutions stemming from RCT may have negatively affected agriculture and agroindustry in African countries. Some evidence from Turkey also displays that a degree of de-industrialisation has taken place after the adoption of exportoriented industrialisation combined with trade and financial liberalisation (Tonus, 2007).

Neoliberal policies can hinder development and propel farmers to abandon their agricultural activities. Swelling interest rates to attract financial capital have curbed agricultural investments in rural areas, where shrinking public investments have led to the deterioration of rural infrastructure (Chakraborty, 2015; Kelly, 2001). When farmers need to obtain agricultural credits, they have faced limited amounts of credits (due to declining state-backed credits) and higher interest rates because of market reforms (causing more dependence on

\footnotetext{
${ }^{74}$ The data provided by the WB has some deficits; for example, former socialist countries have no data for the period between 1981 and 1991.

${ }^{75}$ Regardless of any consensus on its definition and indicators in the literature, de-industrialisation may be recognised as declining manufacturing in Stein's study (Stein, 1992), and the absolute size of manufacturing and its share in GDP have dropped below their predicted levels (Jalilian \& Weiss, 2000).
} 
informal credits). Given that low crop prices have decreased their income level, the ability of small and medium-scale farmers to repay debts has considerably eroded (Enriquez, 2010 as cited in Horton, 2013), which resulted in their marginalisation in land, input and commodity markets, selling lands to affluent farmers and rural elites and seeking employment in urban informal sectors (Banerjee, 2015; Toussaint, 1999, pp. 144-146).

Furthermore, 'instituting rules promoting liberal capital markets and deregulating banking to attract capital flows [...] with rising interest rates' caused financialisation (Arrighi, 2007, p.145 as cited in McMichael, 2012), and financial capital were directed in the 2000s to make profits from speculation in land, food and biofuel (McMichael, 2012). Such speculative transactions have given rise to soaring agricultural prices after 2003, and investments have been directed to purchase physical agricultural assets, such as lands, processing plants, in developing countries that offer relatively low-cost natural resources and labour (McMichael, 2012), which means the dispossession of local farmers by global corporates (B. White, Borras Jr, Hall, Scoones, \& Wolford, 2012).

As developing economies gear up to international market conditions, structural adjustment programmes require devaluation to recover the balance of international payments and create competitive exchange rates. Devaluation, however, dramatically increases the operational costs of industrial and agricultural enterprises and poses a high risk of failure in satisfying export targets and demand for industrial and agricultural goods (Stein, 1992). Some evidence shows soaring agricultural prices straight after the implementation of structural adjustment programs which create shocks and obstruct the supply of industrial goods (Stein, 1992).

According to the presumption made by Bates (2005) in Markets and States in Tropical Africa, agricultural trade liberalisation must have favoured agricultural producers regarding price levels. Chart 2.1 displays that neoliberalism or pro-market actors have not fulfilled their commitment to conferring more favourable prices on agricultural producers. Indeed, real food prices drastically fell between 1990 and 2003, especially at the expense of staple crop producers, such that per capita cereal production has nearly remained static over last three decades (Chakraborty, 2015). Though there has been a rising trend in agricultural commodity prices since 2008 , Chakraborty contends, ' $[\mathrm{I}] \mathrm{t}$ is the fallout of demand deflationary neoliberal policies that have squeezed the incomes of the peasantry and agricultural workers, especially in developing countries, to such an extent that even simple reproduction in this sector had been difficult [...]', and he adds, 'this led to a decline in the supply of agricultural 
commodities, [...] triggering a supply-demand imbalance in the international market, which eventually caused an upsurge in the prices of these commodities'.

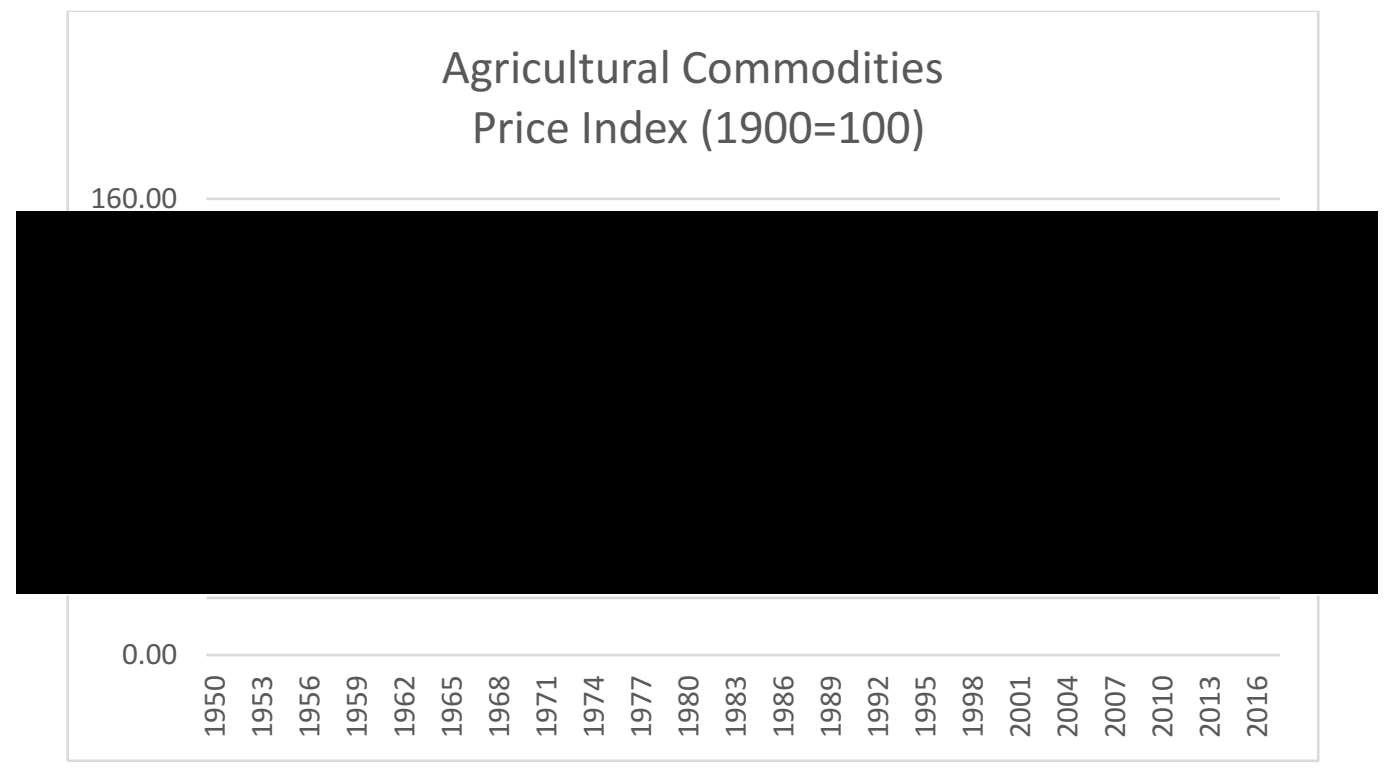

Figure 6.1 Agricultural Commodities Price Index from 1950 to 2017 (Jacks, 2017)

Not only levels of crop prices but also increasing input costs is an underlying factor behind supply deficits. Given that technological and chemical inputs such as machinery and fertilizers account for substantial increases (respectively 50\% and 35\%) in agricultural output in developing countries (Fulginiti \& Perrin, 1998), increases in agricultural input prices and credit costs and cutbacks in input subsidies have highly bedevilled economic activities of small-scale agricultural producers (Banerjee, 2015; Kelly, 2001; Oya, 2007). It is clear that those producers have been economically harmed through trade liberalisation, which makes them susceptible to economic actions of large urban capitalists, multinational companies and actors in retail markets (Chakraborty, 2015). Given increasing production costs, imported food has become more competitive in domestic markets due to liberalisation in trade, and this has forced agricultural producers to leave their economic activities (Toussaint, 1999, pp. 142143). It is noteworthy that despite influx of imported food, many people in developing countries find difficulties to equally access food in both rural and urban areas (Oya, 2010).

As a result, where agriculture is shaped by market-based relationships, smallholders have been worse off than before while local big landowners and traders have boosted their power and wealth (Oya, 2007) in addition to a number of giant corporations dominating markets globally (Chakraborty, 2015). Large scale commercial operators and industrial exporters rather than export-oriented agricultural sector have been able to reap benefits; devaluation, competitive exchange rates and decreasing prices of agricultural crops between 1980 and 
2003 were the driving factors (Toussaint, 1999, p. 140). We can conclude that there is still an urban bias, at the detriment of smallholders, under neoliberal policies. Although the WB criticised the self-interested urban elite (Bienefeld, 1988) as one of the main reason for economic crises in the 1970 s, this case holds true today not only in practice but also in policy-making processes. In other words, neoliberalism has not altered the dominant political position of the urban coalition at the centre and peripheral actors (e.g. smallholders) have been kept away from the decision making processes on national and international levels, set aside some local agricultural projects and resources.

\subsection{Conclusion}

This chapter explained the characteristics of neoliberalism and neoliberal policies and showed the main critical comments on these policies. Neoliberal policies came into practices as pro-market policies after severe crises especially hit less developed countries which had applied government interventions for development. These policies include deregulation, privatisation, monetarisation, and the depoliticisation of the economy. After they caused some political-economic problems, they were upgraded in the 1990s to foster good governance and ease poverty.

Neoliberal policies are applied by the supervision of the IMF and The WB at the global level. The less developed countries that carry out neoliberal transformation are faced with problems such as inequality, poverty and de-industrialisation. South-Asian countries have shown significant performance in developing their economies during the neoliberal period, but their success has come from government interventions to their economy rather than neoliberal policies.

After the chapter showed the relationship between RCT and neoliberalism, it discussed how RCT has contributed to shaping neoliberal agricultural policies. The removal of input subsidies, subsidised purchases, and the state-funded project and programmes are recommended by this theoretical approach. Criticising state-manipulated lower food price policies, it suggests leaving crop prices to be set under free-market conditions. However, the chapter showed that agricultural crops prices have dramatically declined under market dynamics after 1980, and agricultural input prices have surged. Obviously, capitalist classes benefit from neoliberal policies at the expense of smallholders. 


\section{Chapter 7: A Political Economy Analysis of Agricultural Development of the South-eastern Anatolia Region}

\subsection{Introduction}

This chapter will address the question of how Turkey's neoliberal agricultural transformation and government interventions, especially those within the scope of the GAP, have affected the agricultural development of the SAR since 2001. The question will be approached from different perspectives. While we focus on the effects of neoliberal policies on the SAR's agriculture, we will probe into how decreasing agricultural subsidies have affected AEs in the region. Because agricultural policies including subsidy policies are formulated the national level by the MOAF, the main elements of the agricultural liberalisation programme have been implemented in each region in a somewhat similar fashion.

But what markedly differed the SAR from other regions in terms of development policies are the government interventions made within the GAP. Each region has adopted an action plan for development in recent years, but these are not as comprehensive as the GAP. It is noted that regional formal institutional capacity also matters for regional development. The effects of government interventions on agricultural development of the region through the GAPRDA and other regional organisations will be scrutinized.

Agricultural support payments, the main part of government interventions on the national level, are no longer the only external source of income for farmers. Non-farm income possibilities have considerably developed in last fifteen years in west Turkey but are still limited in east Turkey. This has driven family members in east Turkey to migrate to urban areas all across Turkey to find urban employment; those remaining behind maintain their status of small-scale producers and find farm or non-farm jobs to raise their income level (M. Öztürk et al., 2018). Those who migrated are transferring money and goods to those in the rural, while those who do semi-subsistence and subsistence farming are actively be able to operate in the market and change their consumption patterns through this urban-rural network. A similar condition, as well as seasonal migration to other regions, are prevailing in the SAR among SAEs and landless people (V. Koçal, 2015).

At first, the tribal system played an important role in farmers' livelihoods. But then tribal leaders became large landholders getting involved in capitalist production. The sharecropping system has almost disappeared, except for some places in Sanliurfa. Therefore, tribal system 
is excluded from our analysis as it lost its role in dictating how to undertake agricultural activities.

In order to maximise their profits, agricultural producers carry out transactions allocating their resources to two main activities: production and sale. Three main markets determine their real income and activities. They purchase production factors from the input market, bearing production costs and sell what they produce in the commodity market to earn revenue.

Our analysis will start with the first two markets on the regional level. The position of agricultural producers in the market of consumer goods can easily be assessed through agricultural terms of trade. As was discussed in the background chapter, agriculture's domestic terms of trade were against agricultural producers, that is, income transfers have been made through the price mechanism from agricultural producers to the producers and sellers of consumer goods in the period examined. Most industrial and commercial goods and commodities have traditionally flowed from west Turkey to east Turkey. Relatively higher transportation costs and intermediary actors in the region adding their own profits, increased these. We thus presume that income transfers from agricultural producers in the SAR have been more than agricultural producers in west Turkey.

The analysis will continue discussing the privatisation of the TEKEL monopoly and the dominance of free-market dynamics on the tobacco market. The political conflict that emerged in the tobacco market will help us to critically assess present arguments of RCT.

Finally, we will focus on the critical appraisal of Bates (1983, p. 119; 2005, pp. 45-61) who argues that government interventions in the form of projects and programmes are indisputably doomed to fail because of political intentions and arrangements of governments. We will argue that well-designed government interventions based on the poly-centric governance approach could create positive effects for agricultural development.

\subsection{The Effects of the Neoliberal Transformation on Agricultural Production in the South-eastern Anatolia Region}

The most powerful element of the ARIP on agricultural production was the DIS payment, which was allocated according to land size. It did not yield much on Turkey's and the SAR's agricultural production by creating disincentives (see Table 7.1), favoured LAEs more than SAEs given unfair land distribution in the SAR and encouraged LAEs to end their contracts with sharecroppers to legally obtain the payment (Güven, 2009). Some SAEs were forced to 
leave their agricultural activities because of insufficient payments and soaring production costs. Given that land prices soared after the introduction of the DIS (Güven, 2009), those SAEs must also have felt impelled to sell their lands. ${ }^{76}$

The former minister claims that productivity, quality and standard could not be reached through the DIS (Eker, 2015, p. 88). It was replaced over time with a wide range of production-stimulating support payments, such as area-based input payments, deficiency payments, and compensatory payments. This shift in agricultural support policy has received strong criticism from $\operatorname{OECD}$ (2011, pp. 111-112) arguing that it led to market and trade distortions. Nevertheless, it cannot be argued that the government has deviated from agricultural liberalisation. ${ }^{77}$

\begin{tabular}{|c|c|c|c|c|c|c|c|}
\hline \multirow[b]{2}{*}{ Regions/Period } & \multicolumn{3}{|c|}{ Annual Agricultural Growth Rate (\%) } & & \multicolumn{3}{|c|}{ Annual Agricultural Growth Rate (\%) } \\
\hline & \multirow{2}{*}{ 2004-2008 } & \multirow{2}{*}{$2008-2017$} & \multirow{2}{*}{ 2004-2017 } & Regions/Period & \multirow{2}{*}{$2004-2008$} & \multirow{2}{*}{$2008-2017$} & \multirow{2}{*}{$2004-2017$} \\
\hline Relatively Less Developed Regions & & & & Relatively More Developed Regions & & & \\
\hline The SAR & -1.96 & 5.87 & 3.39 & The West Anatolia Region & 0.92 & 4.47 & 3.07 \\
\hline The Central East Anatolia Region & 3.48 & 5.27 & 4.72 & The Mediterrenian Region & 3.79 & 0.18 & 1.28 \\
\hline The North East Anatolia Region & -3.88 & 5.91 & 2.08 & The West Marmara Region & 1.49 & 0.59 & 0.87 \\
\hline The North Black Sea Region & 7.59 & 1.02 & 3.00 & The East Marmara Region & 0.13 & 2.08 & 1.48 \\
\hline The West Black Sea Region & 0.70 & 0.74 & 0.73 & The Aegean Region & 1.60 & 2.73 & 2.38 \\
\hline The Central Anatolia Region & 2.45 & 3.60 & 1.70 & Turkey & 1.11 & 2.50 & 2.07 \\
\hline
\end{tabular}

Table 7.1 Annual Average Growth Rates of Turkey and its Regions at 2011 Prices (Turkish Statistical Institute, 2017e, 2017f, 2018a ${ }^{78}$

Table 7.1 gives us insight into how agricultural policies have influenced different regions of Turkey in the ARIP and the post-ARIP periods. It shows that relatively less developed regions including the SAR performed slightly worse $(1.40 \%)$ than the developed ones $(1.59 \%)$ in the ARIP period in terms of annual agricultural growth rate. It is interesting to see that the SAR had the second-worst performance in that period. In the crisis years of 2001-

\footnotetext{
${ }^{76}$ According to Turkish Statistical Institute, AEs in Turkey equal to or smaller than 10 ha owned $42 \%$ of total agricultural lands in 2001, 34.3\% in 2006, 29.1\% in 2016 (M. Öztürk, 2012, p. 78; Turkish Statistical Institute, 19 April, 2018, 2017b). It is clear that SAEs have long been selling their lands to larger groups of AEs. From this point, some SAEs faced with economic difficulties in the SAR must have disposed of their lands while land prices were soaring.

77 It has reduced the share of total agricultural supports in Turkey's GDP (OECD, 2018), not saved sales cooperatives from bankruptcy, continued to protect intellectual property rights of global input providers (i.e. seed improvements), left agricultural producers getting more loans from private banking companies and privatised companies providing electricity for irrigation.

78 The relatively less developed regions have been defined as ones that have per capita income level less than three in four of Turkey's average per capita income level in Turkish lira.
} 
2002, the cultivated lands increased by around 121,250 ha, since the prospect of being employed in urban areas was significantly damaged, and since some of the displaced people returned to their villages after the end of the armed conflict. However, the land under cultivation fell by around 340,000 ha between 2002 and 2008 (Turkish Statistical Institute, 2018a) and the number of the employed in agriculture hit rock bottom at 255,000 in 2006 (451,000 in 2004) (Turkish Statistical Institute, 2017b). The underlying factor was that Turkey's economy grew by 5.84\% annually between 2002 and 2008, so drove the rural to find urban employment. Another important factor was that the diminution of agricultural support and the withdrawal of the government from subsidised purchases rendered agriculture in the region less attractive, where low productivity agricultural production took place because of lack of capital investments (Koçtürk \& Avcıŏlu, 2007). ${ }^{79}$

In the period between 2008 and 2017, the SAR recovered its loss and has reached the second highest annual agricultural growth rate $(5.87 \%)$. The impressive performance of three subregion of east Turkey between 2008 and 2017 inevitably catches our attention. Once the armed conflict ended, they started to integrate more into input and commodity markets. The dramatic neoliberal economic measures taken after the 2001 economic crisis may have caused delays to reap benefits from market relations. Indeed, the high annual agricultural growth rate has been reached despite the land under cultivation dropping by around 200,000 ha in the SAR between 2008 and 2017 (Turkish Statistical Institute, 2018a). This indicates that a high increase in total factor productivity in agriculture has been behind the relative success in the post-ARIP period. ${ }^{80}$ Given that paid agricultural workers rose from 49,000 in 2007 to 117,000 in 2017 (Turkish Statistical Institute, 2017b), it can be concluded that the mode of production is increasingly being oriented to a productive market-oriented, capitalintensive one.

Apart from the rising orientation to the market, the GAP investments (i.e. public irrigation and village and farmer-level investments), which were dramatically raised by the government since 2008 (The GAP-RDA, 2018, p. 18), have played an important role in agricultural growth and the adaptation of farmers to markets. Added to these investments are the private

\footnotetext{
79 The Central East Anatolia Region, having similar agricultural economic conditions with the SAR, enjoyed agricultural growth rate of $3.48 \%$ per annum between 2000 and 2008 . The underlying factor is that its cultivated lands constantly increased by around 61800 ha between 2000 and 2006, and the employed in agriculture increased from 318,000 in 2004 to 372,000 in 2006 (Turkish Statistical Institute, 2017e, 2017f, 2018a).

${ }^{80}$ According to International Food Policy Research Institute (2017, p. 108), Turkey enjoyed a far higher total factor productivity in agriculture in the period of 2008-2013 (4.8\%) than compared to previous periods $(1.6 \%$ for $1991-2000 ; 1.3 \%$ for $2008-2013$ ).
} 
rural investments that were financially supported through the Instrument for Pre-Accession Assistance in Rural Development (IPARD) after 2007 as a part of Turkey's EU membership bid. Finally, the grants for agricultural mechanisation that were provided by the MOAF under the Rural Development Support Programme (the RDSP) investments were important for the transformation of agricultural production mode to a productive capital-intensive, marketoriented one.

The shift in the composition of agricultural supports was also an important factor. Though the government reduced the weight of total agricultural support payments in GDP, the proportion of production-based support payments in total was raised (by around $42 \%$ in US dollars) (OECD, 2018). Although these are the highly distorting policy tools, it appears that they have improved incentives to production and led to positive results in the SAR. We can claim that more production subsidies would likely have encouraged more agricultural production by avoiding decreases in cultivated areas. The total cultivated areas in Turkey declined by around 2,994,000 hectares in the period between 2000 and 2017 (Turkish Statistical Institute, 2018a). Whilst almost all the regions have experienced this problem, the SAR have had the second-highest decline in cultivated lands, which amounts to around 420,000 ha (Turkish Statistical Institute, 2018a). What is interesting about the figures is that the fall in the cultivated areas was just about 135,000 hectares between 1989 and 1995 during the worst phase of the armed conflict (Turkish Statistical Institute, 1989, 1995).

\subsubsection{The Main Production Strategies of Agricultural Producers and Changes in the Use of Agricultural Lands Associated with Crop Types}

Table 7.2 shows how the use of land for cultivation has changed in Turkey and the SAR. As there is no significant difference between Turkey's other regions and the SAR in this sense (Turkish Statistical Institute, 2018a), we can derive from the data three possible common strategies that have been adopted by AEs in the SAR to cope with changing agricultural policies: a) leaving agricultural activities in a way that leads to depeasantation (M. Öztürk et al., 2018), b) bringing their fallow lands into production, c) contracting areas for field crops and vegetable production and allocating their factors of production to fruit production. 


\begin{tabular}{|l|c|c|c|c|}
\hline Region/Use of Lands & Fallow Lands & Croplands & Vegetable Gardens & Vineyards and Orchards \\
\hline The SAR & -58665 & -440862 & -11795 & 151534 \\
\hline Turkey & -827670 & -2463143 & -100235 & 718275 \\
\hline
\end{tabular}

Table 7.2 Changes in the Use of Agricultural Lands in Turkey and the SAR between 2000 and 2016 (Turkish Statistical Institute, 2018a)

A category of farmers across Turkey, especially those who had relied on rain-fed farming, were forced to leave agricultural activities for economic reasons. New production cost structures turned out unfavourable for them due to decreased input subsidies and the increased use of modern inputs (Ates et al., 2017; M. Öztürk et al., 2018). They also run into difficulties with the changing environment of marketing operations because of the removal of subsidised purchases by state-owned economic enterprises, the deterioration of relationships between cooperatives and farmers, and farmers' inability of accessing commodity markets (Ates et al., 2017). These exacerbated their conventional problems such as the vulnerability to price structure and bad weather, the low productivity of rain-fed farming, and the lack of capital and/or knowledge to invest in new agricultural equipment and methods (Ates et al., 2017; M. Öztürk et al., 2018). Consequently, they left farming.

Bringing more fallow lands into production has become another strategy to increase production and revenues. Yet, this strategy must have increased the use of fertilizer to keep soil nutrients sufficiently high, and in turn, production costs. Özuğurlu (2011, p. 107) puts forward that premium payments given to field crops are playing a part in boosting their production by reducing fallow land areas. It is however noteworthy that according to the Turkish Statistical Institute, AEs tend to let a higher proportion of land lie fallow as their scales raise (Turkish Statistical Institute, 2018b). First MAEs, then SAEs (except for those smaller than $1 \mathrm{ha}$ ) started to bring more fallow land into production (Turkish Statistical Institute, 2018b). Apparently, this strategy was employed by SAEs in an attempt to stay in farming.

AEs in all scales have diminished farmlands and vegetable gardens for producing more fruits and other perennial crops in vineyards and orchards, and they have been more inclined to turn more lands into vineyard and orchards as their scales diminish (Turkish Statistical Institute, 2018b). These crops provide higher value-added than do field crops and mostly tend to be stored longer than vegetables. Furthermore, the fruit types that require less water, energy and fertilizer consumption are preferred such as pistachio, almond, grape and pomegranate. 
Finally, their production requires labour-intensive maintenance and harvesting practices such as pruning and handpicking. Therefore, the use of family labour has become part of the strategy to take cost advantages (M. Öztürk et al., 2018). In this regard, SAEs with unwaged family labour force are more advantageous than MAEs and LAEs. AEs equal to or smaller than 100 da have expanded the area of vineyards and orchards more than MAEs and LAEs (Turkish Statistical Institute, 2018b). An interesting phenomenon is that even SAEs are drawing on agricultural mechanisation in field farming by either purchasing or renting agricultural machineries (Özuğurlu, 2013). It indicates that they are relying on family labour less than before, and the young having remained idle are departing from farming to find nonfarm jobs (Özuğurlu, 2013) and transferring money to the rural in order to sustain familybased agricultural production (M. Öztürk et al., 2018). As I observed, some male members of smallholding families are both working in city or town centres for wages and getting involved in agricultural activities. ${ }^{81}$

\begin{tabular}{|c|c|c|c|c|c|c|c|c|c|c|c|c|}
\hline & & Grains (ha) & $\begin{array}{l}\text { Potato and } \\
\text { Pulses (ha) }\end{array}$ & $\begin{array}{l}\text { Oil Seeds } \\
\text { (ha) }\end{array}$ & $\begin{array}{l}\text { Feed Plants } \\
\text { (ha) }\end{array}$ & Olive (ha) & Fruits (ha) & Grapes (ha) & $\begin{array}{l}\text { Vegetables } \\
\text { (ha) }\end{array}$ & $\begin{array}{l}\text { Plants Used } \\
\text { In Textiles } \\
\text { (ha) }\end{array}$ & $\begin{array}{l}\text { Plants Used } \\
\text { In the Sugar } \\
\text { Industry (ha) }\end{array}$ & $\begin{array}{l}\text { Raw } \\
\text { Tobacco } \\
\text { (ha) }\end{array}$ \\
\hline \multirow{3}{*}{ The SAR } & 2000 & 1596544 & 440494 & 33390 & 1667 & 43014 & 224857 & 126982 & 82942 & 317049 & 1484 & 30600 \\
\hline & 2016 & 1778126 & 255825 & 10471 & 36812 & 80902 & 347352 & 118133 & 71147 & 238326 & 2587 & 11522 \\
\hline & Change & $11.37 \%$ & $-41.92 \%$ & $-68.64 \%$ & $2108.28 \%$ & $88.08 \%$ & $54.48 \%$ & $-6.97 \%$ & $-14.22 \%$ & $-24.83 \%$ & $74.33 \%$ & $-62.35 \%$ \\
\hline \multirow{3}{*}{ Turkey } & 2000 & 13608574 & 1487197 & 634166 & 361400 & 600000 & 1475942 & 535000 & 904377 & 655368 & 408179 & 236569 \\
\hline & 2016 & 11361896 & 844966 & 902396 & 1867202 & 845542 & 2048448 & 435227 & 804142 & 416009 & 321957 & 92505 \\
\hline & Change & $-16.51 \%$ & $-43.18 \%$ & $42.30 \%$ & $416.66 \%$ & $40.92 \%$ & $38.79 \%$ & $-18.65 \%$ & $-11.08 \%$ & $-36.52 \%$ & $-21.12 \%$ & $-60.90 \%$ \\
\hline
\end{tabular}

Table 7.3 Crop Groups and Changes in the Cultivated Areas in the SAR and Turkey between 2000 and 2016 (Turkish Statistical Institute, 2018a)

Table 7.3 demonstrates how the cultivated areas of main crop groups in the SAR and Turkey have altered during the neoliberal agricultural transformation. It is clear that the decrease in

\footnotetext{
${ }^{81}$ Özuğurlu (2011) points out that this phenomenon has been prevailing all across Turkey. He uses a concept of "the necessity for labour force of household" to explain it. If the necessity of labour force of a household is low, the labour force reserve could be transferred to non-farm activities to increase income. In the same vein, the necessity of labour force of a household is relatively higher, the labour force reserve is more likely to be allocated to farming activities (pp.98-99). The scale of AEs are also important here. Insofar as it grows, the household tends to allow the family labourers to hunt for non-farm jobs and hires waged labourers (pp.99-100).
} 
cropland has come from a dramatic decrease in the cultivated areas allocated to pulses, oil seeds, cotton, raw tobacco and cumin as a spice plant (see Table 7.4). First the production of feed plants (maize silage and others), then of grain and sugar appears to have slowed the decrease in cropland.

Dramatic changes in the cultivated areas of fruits and other perennial crops should be noted. Pistachio and olive are the most preferred crops when farmers decide to alter the mix of their crop production. Further, AEs appears to have directed their resources to nuts (e.g. almond and walnut) and to the fruit types they expect more profits, such as pomegranate, apple, cherry and strawberry. The production and cultivated areas of all the grape types (e.g. table grapes, wine grapes, grapes for raisins) have been on the decrease since 2010, which amounts to areas of around 14500 ha and to around 47500 tonnes (Turkish Statistical Institute, 2017c).

In the following sections, we shall focus on how neoliberal agricultural policies and government interventions have induced these changes in agricultural production and created positive and negative results.

\subsubsection{Agricultural Production Costs, Input Subsidies, and the Input Market}

Having a critical discussion about government interventionist policies, Bates (2005, pp. 5051) emphasises that '[g]overnments in Africa subsidise[d] fertilizers, seeds, mechanical equipment, and credit' through the overvaluation of manipulated exchange rates that decreased the perceived prices of imported inputs, and 'the governments of Africa thus intervene[d] in in the markets for farm inputs [...] to depress the price of the inputs and thereby enhance the profitability of farming' (p.54). African governments framed their policies in such a way that subsidised inputs are not available for SAEs but for LAEs through political influence (p.55). This policy created disincentives for SAEs to produce more crops and the result is agricultural stagnation and food insecurity. The neoliberal prescription for solving the failure has involved the removal of input subsidies and the determination of input prices and exchange rates under free market conditions. However, in Turkey, it was adapted to the prevailing conditions in its agricultural sector. Indeed, Turkey ended input price subsidies and left the determination of input prices to markets (Oyan, 2015, pp. 120-121); yet, she has been gradually lessening the weight of input supports in GDP from $5.96 \%$ of agricultural GDP in 1999 to $2.88 \%$ in 2015 (OECD, 2018). 


\begin{tabular}{|c|c|c|c|c|c|c|c|c|c|c|c|c|c|c|c|c|}
\hline 㟒 & 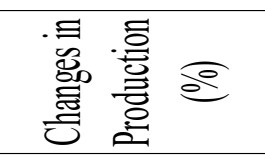 & $\begin{array}{l}\text { ปे } \\
\text { ఫे }\end{array}$ & $\frac{\partial}{\partial}$ & $\underset{⿱ 亠 䒑}{\stackrel{\partial}{\sigma}}$ & 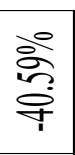 & $\begin{array}{l}\text { ڤิ } \\
\text { के }\end{array}$ & हैं & 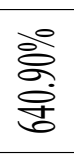 & $\frac{\stackrel{2}{2}}{\stackrel{9}{+}}$ & 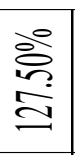 & 密 & 总 & 纺 & $\frac{b^{\circ}}{\frac{\infty}{6}}$ & $\begin{array}{l}\dot{2} \\
\dot{5} \\
\dot{5}\end{array}$ & $\begin{array}{l}\text { 令 } \\
\stackrel{0}{0}\end{array}$ \\
\hline 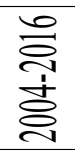 & 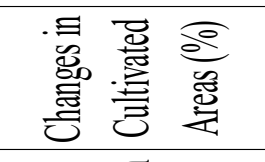 & $\begin{array}{l}\stackrel{0}{5} \\
\stackrel{5}{2}\end{array}$ & $\begin{array}{l}00 \\
0 \\
\frac{0}{9}\end{array}$ & $\begin{array}{l}\stackrel{0}{6} \\
\text { तi }\end{array}$ & $\begin{array}{l}\hat{2} \\
\infty \\
\text { iे }\end{array}$ & $\begin{array}{l}\frac{\partial}{\sigma} \\
\frac{\partial}{\leftrightarrows}\end{array}$ & 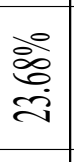 & 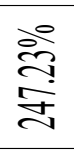 & $\begin{array}{l}\partial े \\
\text { 令 } \\
\text { है }\end{array}$ & $\frac{\stackrel{2}{E}}{\text { हैं }}$ & 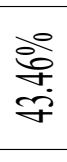 & $\frac{\hat{b}}{i}$ & 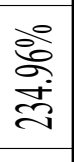 & 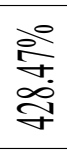 & ${ }^{20}$ & $\begin{array}{l}\text { हैं } \\
\text { छे }\end{array}$ \\
\hline \multirow{2}{*}{$\stackrel{\varrho}{\nexists}$} & 急总言㤩 & $\begin{array}{l}\frac{\infty}{\approx} \\
\text { శ్ }\end{array}$ & 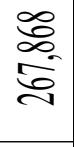 & $\sqrt{\approx}$ & ב) & 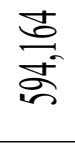 & $\frac{8}{\frac{8}{2}}$ & $\underset{\tilde{2}}{\stackrel{2}{n}}$ & $\begin{array}{l}\approx ్ \\
\infty \\
\infty\end{array}$ & శ్ & $\begin{array}{l}80 \\
8 \\
=\end{array}$ & 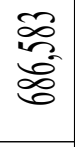 & $\begin{array}{l}\stackrel{2}{2} \\
\equiv\end{array}$ & $\frac{\Omega}{\infty}$ & $\bar{\sigma}$ & $\begin{array}{l}\stackrel{8}{\circ} \\
\frac{8}{8}\end{array}$ \\
\hline & 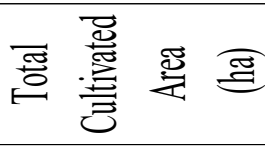 & \begin{tabular}{l}
$\infty$ \\
\multirow{2}{*}{} \\
:
\end{tabular} & 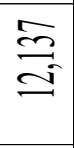 & $\stackrel{\vec{E}}{\vec{m}}$ & 志 & $\begin{array}{l}\text { హ్ } \\
\text { హิ }\end{array}$ & 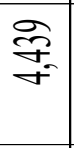 & $\frac{\infty}{2}$ & है & $\underset{\overbrace{}}{\stackrel{\overbrace{}}{\ddagger}}$ & $\begin{array}{l}\overline{\text { है }} \\
\hat{\text { हे }}\end{array}$ & $\stackrel{\approx}{\overparen{\infty}}$ & $\underset{\text { 㞼 }}{\text { m }}$ & 㐫 & $\stackrel{\Xi}{\Xi}$ & $\begin{array}{l}\hat{\xi} \\
\hat{\infty}\end{array}$ \\
\hline \multirow{3}{*}{ 总 } & 粘鄫 & 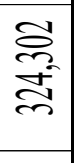 & 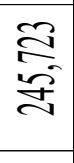 & 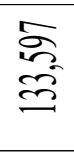 & $\begin{array}{l}\text { 亮 } \\
\text { हn }\end{array}$ & $\begin{array}{l}\text { 造 } \\
\text { 点 }\end{array}$ & $\begin{array}{l}\hat{\sigma} \\
\hat{8}\end{array}$ & ్ㅛ & $\underset{n}{\frac{n}{n}}$ & $\underset{8}{8}$ & $\underset{\approx}{\stackrel{2}{\sigma^{2}}}$ & 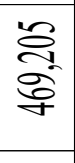 & $\underset{\tilde{5}}{\tilde{3}}$ & $\underset{\mathrm{g}}{\mathrm{g}}$ & $\stackrel{8}{\stackrel{8}{=}}$ & 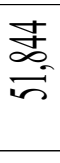 \\
\hline & 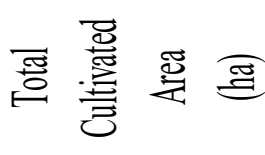 & 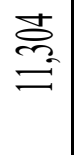 & 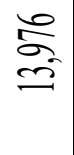 & $\begin{array}{l}3 \\
+5 \\
\text { in }\end{array}$ & ঙ্ণ & 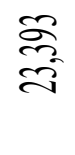 & 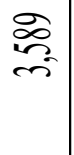 & 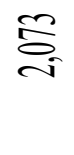 & $\tilde{\infty}$ & 8 & $\begin{array}{l}\text { 冚 } \\
\equiv\end{array}$ & 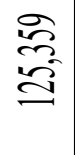 & 志 & F & S్ & $\stackrel{2}{\approx}$ \\
\hline & 总 & 器 & 屁 & 总 & $\frac{\bar{\Xi}}{\stackrel{0}{2}}$ & 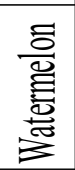 & 离 & 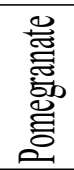 & 高 & $\begin{array}{l}\text { 言 } \\
\text { 吾 }\end{array}$ & 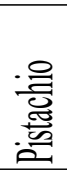 & 营 & 参 & 密 & 㤩 & $\frac{\mathscr{g}}{\sigma}$ \\
\hline 旁 & 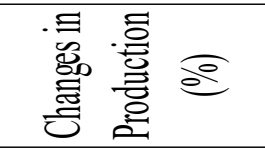 & 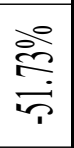 & $\begin{array}{l}\text { ڤે } \\
\text { ฮे }\end{array}$ & 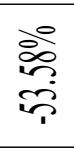 & 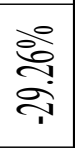 & $\begin{array}{l}\stackrel{\partial}{\mathrm{g}} \\
\text { ב }\end{array}$ & $\begin{array}{l}\frac{0}{2} \\
\infty \\
\infty\end{array}$ & 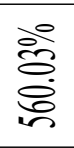 & $\begin{array}{l}\frac{0}{5} \\
\frac{1}{2}\end{array}$ & $\begin{array}{l}\stackrel{\hat{\Xi}}{\hat{\Xi}} \\
\stackrel{\Xi}{=}\end{array}$ & 흥 & 旁 & $\frac{\partial}{\infty}$ & $\begin{array}{l}\dot{0} \\
\text { के } \\
\text { के }\end{array}$ & $\frac{0^{\circ}}{0^{\circ}}$ & के \\
\hline 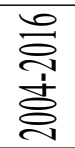 & 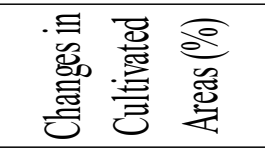 & $\begin{array}{l}\frac{a}{2} \\
\frac{2}{2}\end{array}$ & $\frac{\text { aे }}{\mathrm{i}}$ & $\begin{array}{l}0 \\
0 \\
3 \\
3 \\
0\end{array}$ & $\frac{0}{20}$ & $\begin{array}{l}\frac{\partial}{\partial} \\
\frac{\partial}{y}\end{array}$ & $\frac{\text { ळे }}{\text { के }}$ & $\frac{\stackrel{8}{0}}{\stackrel{8}{8}}$ & $\frac{\sqrt{8}}{\frac{2}{2}}$ & $\begin{array}{l}\frac{0}{2} \\
\stackrel{\sigma}{\sigma}\end{array}$ & હેं & 总 & $\frac{2}{\frac{2}{2}}$ & $\begin{array}{l}\frac{0}{0} \\
\text { के }\end{array}$ & 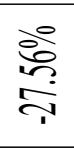 & 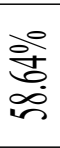 \\
\hline \multirow{2}{*}{ 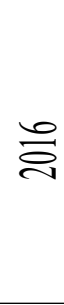 } & 㞼总言 & $\begin{array}{l}8 \\
\infty \\
0 \\
2 \\
2\end{array}$ & 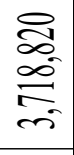 & $\begin{array}{l}\varrho \\
\text { o } \\
\text { f }\end{array}$ & 惡 & $\underset{⿱ 乛}{\stackrel{\Xi}{ \pm}}$ & ஜ్ & $\begin{array}{l}2 \\
2 \\
2 \\
\sigma_{0}\end{array}$ & 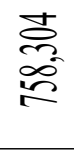 & $\underset{\sigma}{\infty}$ & $\frac{\infty}{\infty}$ & $\begin{array}{l}\text { 옹 } \\
\text { dै }\end{array}$ & $\stackrel{\widetilde{\Omega}}{\stackrel{\widetilde{S}}{=}}$ & 6 & 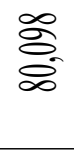 & 요 \\
\hline & 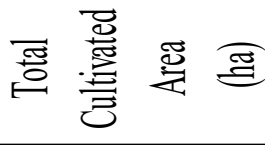 & 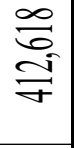 & 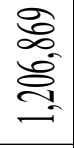 & 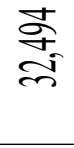 & $\begin{array}{l}\bar{\Xi} \\
\bar{\Xi}\end{array}$ & कू & 导 & $\bar{\Xi}$ & $\begin{array}{c}\stackrel{8}{8} \\
\infty \\
\infty\end{array}$ & $\begin{array}{l}\infty \\
\stackrel{8}{8}\end{array}$ & $\begin{array}{l}\approx \\
\approx \\
\text { के } \\
\approx\end{array}$ & $\begin{array}{l}\bar{\infty} \\
\text { s. }\end{array}$ & $\stackrel{\widetilde{\Omega}}{\stackrel{\Omega}{=}}$ & $\simeq$ & 羔 & శ్ \\
\hline \multirow{3}{*}{ 总 } & 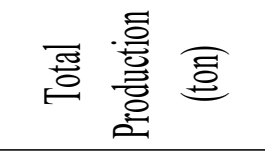 & 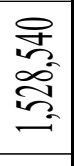 & $\begin{array}{l}8 \\
8 \\
0 \\
0 \\
0 \\
0 \\
0\end{array}$ & $\stackrel{\varrho}{\text { 三 }}$ & $\begin{array}{l}8 \\
\text { ज } \\
\text { I }\end{array}$ & 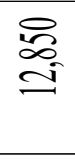 & $\mathbb{E}_{0}$ & 关 & $\begin{array}{l}\stackrel{8}{2} \\
\infty \\
\infty\end{array}$ & & 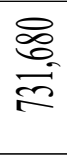 & 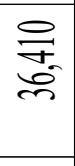 & 亭 & $\begin{array}{l}2 \\
\infty \\
\infty \\
\infty\end{array}$ & $\stackrel{\infty}{\stackrel{\infty}{\check{a}}}$ & $\begin{array}{l}3 \\
\approx\end{array}$ \\
\hline & 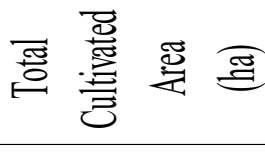 & $\begin{array}{l}\vec{J} \\
\text { J } \\
\text { 宁 }\end{array}$ & $\begin{array}{l}\text { E } \\
\pm \\
\text { E }\end{array}$ & $\frac{\infty}{\infty}$ & $\frac{\text { E }}{\text { E⿱ }}$ & $\begin{array}{l}n \\
\approx 0 \\
\approx\end{array}$ & $\begin{array}{l}\bar{E} \\
\bar{\sigma}\end{array}$ & $\frac{\infty}{\stackrel{\infty}{\leftrightarrows}}$ & $\underset{\text { E }}{\tilde{S}}$ & $\tilde{\sigma}$ & 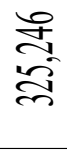 & $\frac{ \pm}{\infty}$ & 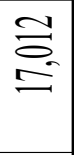 & $\stackrel{\infty}{g}$ & 早 & $\underbrace{\infty}_{0}$ \\
\hline & 龸 & $\frac{\grave{\Xi}}{\grave{n}}$ & $\begin{array}{l}\text { 吾 } \\
\end{array}$ & 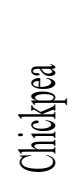 & 焉 & 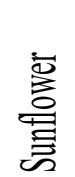 & $\begin{array}{l}\text { 营 } \\
\text { 赑 }\end{array}$ & 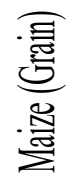 & 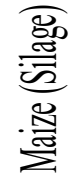 & 愛 & $\begin{array}{l}\text { 总 } \\
\text { 言 } \\
\text { 夏 }\end{array}$ & 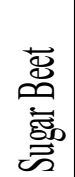 & 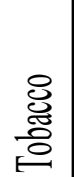 & 䏤 & 흥 & 을 \\
\hline
\end{tabular}

Table 7.4 Cultivated Lands and Production Levels of the Most Produced Crops in Each Crop Groups in the SAR between 2004 and 2016 (Turkish Statistical Institute, 2017c) ${ }^{82}$

\footnotetext{
${ }^{82}$ The Turkish Statistical Institute just provides the statistics for each crop type starting from 2004 (for those of tomato from 2006 and of cucumber from 2005). This is why Table 7.4 cannot demonstrate the 2000 figures.
} 
Our analysis will show how dynamics in the input market have affected agricultural producers in the SAR vis-à-vis various input providers. We, in doing so, will show that an insufficient level of input subsidies has not eased the problems of agricultural producers, but input subsidies promoted productivity, encouraging the use of highly productive inputs. The question of who has reaped their benefits will reveal the character of neoliberal transformation in agriculture.

\section{Commonalities}

Input and input-related subsidies became one of main elements of the agricultural support system after the introduction of the Agriculture Act in 2006 (The OECD, 2011, p. 47). Among the most prominent are the improved, certified seed, seedling and sapling (ICSSS) support $^{83}$, the area-based diesel and fertilizer (DF) support, the area-based soil analysis (SA) support and loan concessions.

We need to highlight three issues about input subsidies. First, production-based supports require the use of innovative agricultural inputs sold in the market, such as improved seed varieties, fertilizers, pesticides and machineries. Second, various production-based supports including input subsidies, were raised nominally in US Dollar after 2005, and this has led to productivity increases ever since (as seen in Table 7.4). ${ }^{84}$ Nevertheless, the level of input subsidies (\%3.55 of agricultural GDP in 2016) has remained less than its 1999-level (5.97\%) (OECD, 2018). I was told during fieldwork that nominally increased input subsidies are still far from easing concerns on agricultural production costs.

Every enterprise must make a profit by keeping their production cost, especially input costs, as low as possible. However, the manipulation of input costs is hardly possible for AEs as inputs are commercialised by national and multinational companies under the market conditions structured by liberalisation and globalisation (Keyder \& Yenal, 2014, p. 34). A few companies with high financial power have substantial control in the oligopolistic input market through intellectual property rights (Fuglie, Heisey, King, \& Schimmelpfennig,

Further, the total production values of pistachio are highly erratic in the examined period due to its periodicity tendency or environmental factors such as drought. For this reason, we have taken the 2006 figure instead of the 2004 figure to make our assessment reasonable.

${ }^{83}$ The improved, certified seed, seedling and sapling support is given to AEs after they purchase those inputs. Payments are made in cash relying on the total cost in the receipt, which is matched to the reference amount based on land size that was recorded for each AE in the Farmer Registry System beforehand. Thus, the improved, certified seed, seedling and sapling support is, an area-based subsidy.

${ }^{84}$ Input subsidies were around 1706 US Dollar in 1999, 400 US Dollar in 2005 (the ARIP period), around 1495 US Dollar in 2011 and around 917 US Dollar in 2015. 
2012). They invest in research and development activities for the production of innovative inputs yielding high productivity, and farmers are willing to pay higher prices for inputs, explaining the rising input costs in recent years (Fuglie et al., 2012). However, the factor that has raised concern among farmers in Turkey is that rises in input prices have exceeded rises in commodity prices (Olhan, 2012).

Farmers are today dependent on importing innovative inputs to raise agricultural productivity. Overvalued exchange rates under the free floating regime, which was strongly recommended in the IMF programme after the 2001 economic crisis, have heightened this dependency. ${ }^{85}$ The Turkish lira that greatly depreciated after the 2001 economic crisis became re-overvalued in 2004 and remained so by 2016 thanks to increased international capital inflows (Ertuna, 2005). This matter has moderately kept the difference between input and commodity price increments. With its highly productive characteristic, innovative inputs have helped AEs to substantially grow production volume and revenue. When Turkish lira inescapably started to dramatically depreciate after 2015 with the influence of contracting international capital flows, AEs all across Turkey, which already complained about the high input prices determined by big companies with oligopolistic power (Ates et al., 2017), started to experience problems (Donat, May 24, 2018).

The following excerpt from an interview with focus group F3 (personal communication, July 14, 2015) in Diyarbakir clarifies that even middle-scale and large-scale landholders are running into trouble with managing production costs.

F3: [...] I told [this] friend, "You were making wheat cultivation 50 years ago". 50 years later, he is still making agriculture on 500 or 1000 decares. Those lands belong to him. $\mathrm{He}$ is my close friend; his name is Hajji $\mathrm{K}$ [...]. [...] Let me tell you what he wanted to say. He told, "We used to do some work with manpower but some work with animal power, I mean ox power or horse power, [for] ploughing, harvesting, etc." [...] Today, we are cutting [wheat] with a tractor, and then we have turned to a combined harvester. At that time, we were cultivating - we were not giving [chemical] fertilizer [to our lands]; we were giving animal manure; we were getting more quality products. [...] If five or six grains on every ear of wheat got ripe, [then] it was saving us. Today, even if 15 grains got ripe on an ear of wheat, -we have [here] mentioned new seeds, new varieties, and the new agriculture- they would not save us. Because all business is done

\footnotetext{
${ }^{85}$ Overvalued exchange rates have always been a chronical problem for Turkey's economy. Before the 2001 economic crisis, Turkey had the same problem under the fixed exchange rate regime recommended by the IMF.
} 
by commercial payments, [such as renting] a combined harvester via a payment [or] a tractor via a payment, [and buying] fertilizer via a payment $[\ldots]$.

Interviewer: [...] If [agricultural] supports ceased, would you give up production completely?

Hajji K: [we would do it] willy-nilly

F3: Because it would not save us. ${ }^{86}$ I would quit.

In fact, agricultural producers throughout Turkey are seriously in need of getting more subsidies to keep up the use of productive innovative inputs (Ates et al., 2017). Otherwise, they use less inputs to reduce production costs, ending up with a loss of productivity. As Bates (2005, p. 82) argues, 'in the face of declining prices, producers devote fewer resources' to production in the short run, that is, 'they harvest less intensively and place fewer acres under production'. Bates talks about the African agricultural development having impeded with highly interventionist policies; yet, the neoliberal transformation is pushing the Turkish agriculture to a similar failure.

This case is easily seen in the cultivation of grains, pulses, maize and cotton which prevail in the region examined. Those crops are more productive through capital-intensive methods, which inherently require the use of more chemical and biological inputs in order to mount agricultural productivity. Increases in the relative price of inputs to crops are forcing farmers into financial vulnerability. Another pressure comes from the nature of using capital intensive methods. Their costs diminish over time, and therefore AEs cannot easily alter their crop patterns in the short run when they face economic instability or vulnerability (Keyder \& Yenal, 2014). In this lock-in situation, they follow the only way: reduce the production costs to cope with shocks. This, however, could impair crop productivity. In a focus group session, F8b (personal communication, July 26, 2015) explains how cost-saving negatively affects the full exploitation of agricultural techniques and methods.

F8b: [...] in view of avoiding costs, (any farmer, here,) does not plough his field properly. For instance, now, the state would tell him to spread 20 kilos of cotton seed on his field. It is really enough if you prepare your field well. But, now, that farmer would think that he hasn't made a proper field preparation, so he would spread 30 kilos of the seed. It is just equivalent to the 20 kilos of seed the state suggested. [...] There would be 10 kilos of difference because of [insufficient use of] diesel [for ploughing]. As for fertilizer, $[\ldots]$ he can buy 1 kilo of fertilizer with 3 kilos of wheat. So, he cannot properly

\footnotetext{
${ }^{86}$ It means that it would not fully cover the cost.
} 
use fertilizer. For instance, I would tell him, "let me give you leaf fertilizer as a supplement for the top of plants". He would reply me, "I cannot earn money, so don't give me it". If possible, he would not use pesticides. [...] [Consequently, we are] working on cotton for getting agricultural support [premium payments, a.n.].

As things stand, the complete removal of subsidies would result in an inevitable failure in agriculture in the SAR. F4 ${ }^{87}$ (personal communication, July 14, 2015), cultivating grains and lentil on a 125 decare of non-irrigated land, expressed that the ICSS subsidy was a decisive factor for his use of certified wheat seeds, as without it he would not use such seeds. During our focus group discussion, F9c (personal communication, July 26, 2015) from Mardin argued that he was spreading certified, improved wheat seeds on his 60 decare of nonirrigated land because of its high productivity, and firmly claimed that if the subsidy was abolished, he would use certified seeds to cultivate the first year crop but select his own seeds from that crop to produce the second and third year crops. ${ }^{88}$ In fact, some small- and mediumscale producers told me that they were employing such a strategy to lessen their production costs at the expense of degrading the quality and productivity of their crops and ultimately receiving lower prices from the agro-food industry.

Improved seeds, fertilizers, pesticides, machineries and equipment are, indeed, highly productive inputs. AEs should not have to give up their use because of lack of subsidies. One can regard cooperatives as a market-adapted solution to get those productive inputs at lower prices, where uncompetitive market conditions in the input market work against AEs. Yet, as an inherent characteristic of agricultural producers they are vast in number, spread out over a large geographical area, and this imposes a great barrier on them to act collectively to lower the prices of the inputs they buy.

Despite all this, there had been cooperatives granting inputs to farmers before the ARIP, financially assisted by the government. After the ARIP, the existing sales cooperatives were doomed to a failure with the withdrawal of financial assistance. For example, the Guneydogu Birlik went into liquidation; the Gapbirlik entered an inactive position; the Cukobirlik is very limitedly operating with a low level of financial resources after serious cutbacks. All of them would however distribute inputs to AEs at subsidies prices before 2001 (Karli \& Çelik, 2003, pp. 64-65). The manager of the Cukobirlik at Sanliurfa city centre (N2, personal

\footnotetext{
${ }^{87} \mathrm{He}$ owns a factory for poultry farming, for which his wheat production is used as forage.

${ }^{88}$ For example, F18, a focus group including a smallholder (F18a) and a medium landholder (F18b) from Sanliurfa, argued that the prices of certified seeds are higher than the prices they expect, and that the subsidy the state gives is far from being worth all their efforts.
} 
communication, April 29, 2015) expressed that they can operate in accordance with market dynamics, but the government must inject financial resources into the cooperative, as they did to the Agricultural Credit Cooperatives (ACC) before. The ARIP cooperatives were, however, forced to find financial resources from the market but not from public financial organisations. The cooperatives in the SAR therefore could not repay their debts they obtained at the market interest rate and lost their capability of offering inputs and credit to their members. In fact, the ACC staff received technical assistance as well, instructing how to operate in the market. The staff of the sale cooperatives did not receive such assistance, and without financial resources they easily failed in executing their tasks.

Where the agricultural cooperatives in the SAR are unable to attract support from the government, it should be noted that producers unions have been encouraged to be set up through financial and technical assistance supplied by the government and international organisations such as the UNDP and the EU within the scope of the IPARD and the EU-CAP. According to Abdullah Aysu, the Chairman of the Confederation of Farmer Unions, the law of Agricultural Producers Union does not however give a mandate to these unions to purchase inputs wholesale at lower prices from input providers and sell to their partner farmers (Aysu, 2013).

Obviously, a vast number of AEs are unlikely to obtain inputs from their own organisations at lower prices. As many SAEs in the SAR have no economic power to pay nominal costs of inputs in cash, they apply to formal and informal credit mechanisms. Private banking companies have expanded their operations in the SAR after subsidised credit was removed within the ARIP. However, the Agriculture Bank and ACCs started after mid-2000s to provide AEs with loans at interest rates lower than market interest rates or at a zero interest rates with a view to support the purchase of productive inputs ${ }^{89}$ and the use of innovative methods such as organic agriculture and good agricultural practices. I was however told that smallholders are supposed to pledge a high value of collateral despite owning a low level of assets. Even worse, land is occasionally used to secure loans at the risk of losing them if defaulted on the loan. The risks posed by the unsolved Kurdish Question have also kept the required level of collateral high. For all these reasons, SAEs are far more inclined than MAEs and LAEs to seek credit from informal sources ranging from relatives to input providers or merchants.

\footnotetext{
${ }^{89}$ Those productive inputs and investments that can be bought at lower interest rates are improved livestock breed, modern bee hives, poultry and fishery animals and equipment, agricultural machineries and equipment, improved certified seeds, seedlings, saplings, irrigation equipment, modern greenhouse investments, etc.
} 
The informal credit mechanism can be characterised as an exploitative mechanism at the expense of SAEs. F17, a smallholder in Adiyaman says:

F17: [...] For instance, one would bring fertilizer, diesel and seeds by loan. [...] assume that fertilizer and seed are 900 Turkish liras, if you brought them by loan, they would be 1200-1300 Turkish liras. [...] [Later on] he would sell earlier what is in his hand to pay money for [renting] a combined harvester or [buying] fertilizer.

Interviewer: Actually, fertilizer and varieties of wheat are normally available, but you have always a financial problem.

F17: Smallholders always have financial problems. The government does not give us fertilizer now but before; [...] [thus,] they made agricultural lands adapted to fertilizer. $[\ldots]$ farmers are buying fertilizer in cash now.

Prior to the planting season, many SAEs often apply to a merchant or a broker or an input seller for a loan to gain the required inputs, so paying interest after harvesting. Assume that a SAE is supposed to repay by selling their crops to that merchant just after the harvest, that SAE would miss a chance to sell his crops later for a higher price by taking advantage of seasonal supply deficit and market fluctuations, but the merchant would have such a chance to augment his profit margin. In this way, the market mechanism and lack of subsidised credit and input subsidies have clearly led to the exploitation of especially SAEs and MAEs. I was told that the formal credit mechanism explicitly works in favour of LAEs in the SAR. Bates (2005, pp. 56-58) puts forward the usefulness of market-based policies by arguing that government interventions were responsible for LAEs accessing credits at the expense of SAEs in African cases. The case of the SAR however shows that market-based policies have not worked well for SAEs.

In respect of obtaining inputs, farmers have been crippled by formal institutional arrangements at the national level as well. For example, with the introduction of the Act of Seed Growing, only the seeds that have been registered and patented by the MOAF are accepted legal to be produced and traded, and farmers, therefore, cannot legally sell or exchange their own seeds for trade ("Tohumculuk Kanunu [The Act of Seed Growing]," 2006). The act definitely sought to favour the global and national seed companies that have financial and technical capability of registering and patenting seeds (M. Öztürk et al., 
2018).$^{90}$ As Değirmenci (2014, pp. 148-149) states, after the seed growing sector was opened up to private actors in 1984, the General Directorate of Agricultural Enterprises (TIGEM) have already lost its status of being a state monopoly over the production of seeds and have not even fulfilled the function of regulating the seed market later. Consequently, national and global seed companies are diffusing their power in the seed market and forcing AEs to become almost entirely dependent to them.

This is evident in the case of F1 hybrid seeds ${ }^{91}$ that are planted for the cultivation of cotton, maize, field fruits (e.g. melon and water melon) and vegetables. These highly productive seeds are improved by global seed companies, spending large sums on research and development to obtain their intellectual property rights. Those who sow F1 hybrid seeds do not receive any ICSSS support although they are supposed to buy those seeds every year to maintain their agricultural production (they cannot be re-selected from the harvested crop owing to technical-biological impossibilities). The Act of Seed Growing here renders them more dependent to global seed companies by preventing farmers from trading their own seeds. Given that most vegetable producers are comprised by SAEs, the lack of subsidy for F1 hybrid seeds also makes them more vulnerable.

This is also evident in the case of national seed growing companies. The seeds of many field crops are improved by public research bodies, and the government covers research and development expenditures with public financial resources. The improved seeds are distributed to national seed growing companies, where global companies do not consider the production or import of most of such seeds profitable (Acikgoz, 2005, p. 5). The subsidisation of research expenditures has actually averted a possible market failure. However, national seed companies offer high prices to farmers buying those certified, improved seeds although they barely invest in research and development. F7b clarifies the unfair price differential between the seed price and the crop price: '[a ton of] certified [wheat] seeds is 1400 Turkish liras. The commodity [a farmer] would sell is 700 Turkish liras. There is a hundred per cent of difference.' It is manifest that the market mechanism and the lack of

\footnotetext{
${ }^{90}$ This act also facilitated the establishment of an internet-based network between urban gardeners and peasants getting involved in the exchange of seeds (M. Öztürk et al., 2018). However, the mass production of agricultural commodities has been possible with the use of commercial seeds to a very great extent.

${ }^{91}$ The scientific meaning of F1 hybrid in biology is out of our interest. However, for any readers in the field of political science, we can explain main characteristics of it within our context. O9 (personal communication, September 30, 2014) tells me that the maize cultivation is depended on F1 hybrid seeds. The main characteristic of hybrid seeds is that if any farmer generated seeds from them for his cultivation in the next year, he would exactly yield no crops because germination would be impossible. Hybrid seeds, providing high productivity, lead farmers to become dependent on the terms offered by seed companies.
} 
government interventions in the seed market (e.g. TIGEM's inability to regulate it) work at the expense of farmers.

Farmers have been also harmed by the lack of governmental interventions in agricultural research and development. R7 (personal communication, July 24, 2015), a managerresearcher in a regional agricultural research organisation, stated that unlike field crops, vegetable and fruit seeds, seedlings and saplings have not been properly improved by national and regional research bodies so far, except for pistachio, olive and grape. SAEs, therefore, devote their resources to these three types of fruits since they do not know how to grow other types of fruits because of lack of public agricultural extension, which limits alternative ways of earning income.

AEs have been left alone in the input market against big private companies during the neoliberal agricultural transformation. They have lacked the required support from the state and the farmer organisations that weakened with the withdrawal of government support. Where imperfect competition is prevailing in the input market, increased agricultural surpluses are being transferred to global and national input providers, local input sellers, and to those renting out machinery. Note that the economic benefits derived from innovative, productive inputs are also being exploited by agro-industrial companies benefitting from lower market prices to buy agricultural commodities, and intermediaries such as banking companies and merchants.

\section{Variations}

Depressing relative prices of crops to inputs is a major problem, especially in dry-land farming as compared to irrigation farming, since the former is less productive than the latter (see Table 7.5). The focus group interview conducted with F9 included smallholders in Mardin, and explains how lack of irrigation water and adverse changes in relative prices of crops have forced SAEs, small-scale tenants and sharecroppers to abandon their activities.

F9a: [...] water is not available any more. Those who cultivate wheat have a lot of difficulties here. $[\ldots]$ There were no people in the village; all of them migrated [to urban areas]. Now, there are two or three old people in the village. That's all.

F9b: [...] Fifteen years ago I was cultivating cotton on my lands. There was a worker irrigating and farming in return of 1.5 tons of cotton. He could get by on 1.5 tons of cotton. Now, if I gave him 5 tons of wheat, I mean if we cultivated jointly, then we could not make even a little bit profit. 
F9a: He could not get by on it. Now, producers [here] are only landholders. In the past, if you had not owned a land, you could have got by on a 10 decare of land by renting, but now even landholders are unable to live on [agricultural income]. Look, wheat price was 600-700 [for one ton] earlier; it is the same now. In the past, we can buy 2 [units of] fertilizer for one [unit of] wheat but it's totally opposite right now. [...] In the past, they did not give us agricultural support money but our due, I mean, the real price of wheat.

'The real price of wheat' here indicates the agricultural prices subsidised in the past, which the smallholder interviewed deems as the real return of his effort. F9a is definitely dissatisfied with the price level determined by market dynamics as it has lessened relative prices of wheat to fertilizer. Önal (2013) shows that this case is also applicable to other field crop types.

\begin{tabular}{|l|c|c|c|c|c|c|c|c|c|}
\hline \multirow{2}{*}{$\begin{array}{l}\text { Agricultural } \\
\text { Crops }\end{array}$} & \multicolumn{3}{|c|}{$\begin{array}{l}\text { Productivity under Rain- } \\
\text { fed Conditions (kg/da) }\end{array}$} & \multicolumn{3}{|c|}{$\begin{array}{c}\text { Productivity under } \\
\text { Irrigated Conditions } \\
\text { (kg/da) }\end{array}$} & \multicolumn{2}{c|}{ Productivity Difference (\%) } \\
\cline { 2 - 11 } & 2012 & 2013 & 2014 & 2012 & 2013 & 2014 & 2012 & 2013 & 2014 \\
\hline Durum Wheat & 236 & 208 & 88 & 462 & 446 & 377 & $95.76 \%$ & $114.42 \%$ & $328.41 \%$ \\
\hline Barley & 289 & 257 & 128 & 428 & 429 & 436 & $48.10 \%$ & $66.93 \%$ & $240.63 \%$ \\
\hline Red Lentil & 180 & 127 & 73 & 231 & 189 & 192 & $28.33 \%$ & $48.82 \%$ & $163.01 \%$ \\
\hline Chickpea & 97 & 95 & 68 & 180 & 180 & 192 & $85.57 \%$ & $89.47 \%$ & $182.35 \%$ \\
\hline
\end{tabular}

Table 7.5 Productivity Differences between Rain-fed and Irrigated Agricultural Methods in the Case of Sanliurfa (Turkish Statistical Institute, 2017a)

In addition, the increasing use of commercial inputs has necessarily resulted in raised production costs (Önal, 2013) $)^{92}$ and narrowed profit margins. However, some AEs with access to irrigation water have a chance to cultivate what they want from a wider range of crop types available (i.e. cotton, maize, wheat, soybean, pepper, tomato, etc.) and furthermore, they can harvest twice or three times in a year with higher productivity. Profit margins occurred under both conditions therefore vary greatly, most notably in dry years (look at the figures of 2014 that represents a dry season in Table 7.5). This difference between rain-fed farming and irrigated farming has caused a quintuple income disparity between AEs in favour of those engaging in irrigated farming (The State Hydraulic Works, 2012).

\footnotetext{
${ }^{92}$ In the period between 2002 and 2015, diesel fuel prices increased by about $236 \%$, the index of fertilizer prices by about $327 \%$. As for agricultural crops, increase rates in wheat and maize prices (relatively by $239 \%$ and $312.5 \%$ ) predominated the increase rate of diesel fuel price in the same period but not the increase rate of fertilizer prices. The increase rates of maize, red lentil, cotton was lower than the increases of these input prices, relatively 195\%, 153\% and 47.5\% (The Institute for Agricultural Economy and Policy Development, 2015).
} 
Dramatic contractions in the lands allocated to pulses, barley and oil seeds (see Table 7.3 and 7.4 again) have resulted from the market-based policies that negatively affect the smallholders doing rain-fed farming. True, the agricultural enterprises which can access irrigation water have stabile income patterns, and they could take advantage of increases in agricultural commodity prices in any drought year due to the reduced supply of agricultural crops (F15, personal communication, August 26, 2015). ${ }^{93}$

Furthermore, they can decrease water consumption and costs and raise crop productivity with efficient irrigation through modern irrigation equipment, such as drip irrigation and sprinkler irrigation systems. In particular, the government grants given after the mid-2000s to cover half the cost of their purchase and installation have helped AEs to increase crop productivity. Although O5 (personal communication, May 5, 2015) claims that LAEs are financially more capable than SAEs to afford the remaining cost, Table 7.6 points to the fact that SAEs have substantially benefitted from the government grants to set up drip irrigation systems (an increase of around $42.5 \%$ ) in vineyards, orchards and gardens. Accordingly, the increased use of modern irrigation equipment through government grants has been one of the underlying factors that helped AEs to offset loss of agricultural production coming from uncultivated lands and to enhance their income to remain in agriculture.

\begin{tabular}{|c|c|c|c|}
\hline & \multicolumn{3}{|c|}{ The Types of Irrigation Equipment } \\
\hline Period & $\begin{array}{c}\text { Various Pump } \\
\text { Types }\end{array}$ & $\begin{array}{c}\text { Sprinkler Irrigation } \\
\text { System }\end{array}$ & $\begin{array}{c}\text { Drip Irrigation } \\
\text { System }\end{array}$ \\
\hline $2002-2005$ & $3.18 \%$ & $12.19 \%$ & $4.10 \%$ \\
\hline $2005-2015$ & $3.03 \%$ & $11.41 \%$ & $42.43 \%$ \\
\hline
\end{tabular}

Table 7.6 The Average Growth Rates of Different Types of Irrigation Equipment in the SAR (Turkish Statistical Institute, 2016b)

In spite of their advantages stemming from irrigation, AEs involved in irrigated agriculture still have problems with production costs. The focus group of $\mathrm{F}^{94}$ (personal communication, July 24, 2015) shows that even MAEs and LAEs that get involved in irrigated farming in Diyarbakir complain about costs and lack of input subsidies:

\footnotetext{
${ }^{93}$ The average price of durum wheat and barley was respectively 760 Turkish Lira (TL)/Ton and 587 TL/Ton in 2012, but $885 \mathrm{TL} /$ Ton and $660 \mathrm{TL} /$ Ton in 2014 (Turkish Grain Board, 2012, 2014). It is clear that rises in crop prices do not offset the loss of crop production made under rain-fed conditions.

${ }^{94}$ In addition to agricultural activities, F7a and F7b run businesses in the centre of Diyarbakir selling fertilizer, seeds and pesticide.
} 
F7a: The support is low; input [costs] are high; diesel is expensive ${ }^{95}$; labour cost is high.

[The government] left prices to the market [...].

F7b: [A ton of] certified [wheat] seeds is 1400 Turkish liras. The commodity [a farmer] would sell is 700 Turkish liras. There is a hundred per cent of difference. [...] He would spread fertilizer on his field two times, and seeds. A litre of diesel is 4.5 Turkish liras.

This would not save that man. Labour cost must be added. [...] If supports were ceased, I would give up agriculture, definitely.

Those who engage in irrigated farming differ from each other in terms of how water is conveyed to their lands, and this criterion determines their production costs.

Some AEs can directly access the irrigation water that can be extracted through a pump engine from a dam reservoir or from the tributaries of the Euphrates and the Tigris. They fortunately incur relatively low electricity or diesel costs of using water (F26, personal communication, July 1, 2015; F20, personal communication, July 5, 2015). Even smallholders, therefore, have the capability to produce crops for markets with high profit margins (Gultekin, 2013). Many SAEs that are located in the mountain villages illustrate this case. They generally produce tobacco and various types of fruits and vegetables in vineyards, orchards and gardens whilst AEs in low-elevated areas mostly cultivate field crops with irrigation water, such as wheat, maize, cotton, pepper, tomato, water melon, melon, tobacco, etc.

If the water is conveyed by gravity-fed irrigation, then the cost of water per cubic meter is relatively cheap, and thus the profit margin is high. AEs with varying scales in Harran and Akcakale plains in Sanliurfa can directly reach water through open channels connected with the gravity irrigation system constructed as a part of the GAP. According to Isgin's study (2006), the average agricultural income in Sanliurfa increased 3,5 times in the first ten years after the Ataturk Dam had started to supply irrigation water to Sanliurfa's plains. However, not every agricultural enterprise has increased their agricultural income at the same level because of unfair distribution of agricultural lands favouring LAEs (Isgin, 2006) and the political-economic dominance of LAEs in irrigation unions (F15, personal communication, August 25, 2015).

\footnotetext{
${ }^{95}$ Turkey is one of the countries with the most expensive diesel among OECD countries. Both increases in the price of raw petroleum and in tax on diesel consumption have mounted diesel prices in Turkey, which has nearly offset the positive effect of the diesel support payments. While other OECD countries lifted tax on diesel consumption in agricultural production, Turkey has not done so yet. Consequently, the diesel cost in agricultural production is four or five times greater in Turkey than in the US (Aktaş, İpek, \& Işık, 2010).
} 
But there area AEs which use irrigation water and which are experiencing financial troubles. Pumping wells are set up through individual investments. Their success is based on the depth of groundwater bodies below the surface (directly effecting electricity bills) and the amount of water available. As costs of drilling, maintaining and operating a pumping well are high, LAEs tend to exploit groundwater more than SAEs (see Figure 7.1 for the main area in which those AEs using pumping wells exist). Easily meeting the criteria about collateral, LAEs can access loans with a low interest rate from the Agricultural Banks and the ACC to invest in pumping wells (O5, personal communication, May 5, 2014). Regardless of scales of economy, the cost of electricity to operate pumping wells creates financial problems for most of the AEs extracting groundwater (F19, personal communication, July 5, 2015; O6, personal communication, April 28, 2015; N1, personal communication, September 16, 2014). A few agriculture enterprises in the region are very fortunate as they can substitute the water extracted from pumping wells for water pumped from rivers (F11, personal communication, July 27, 2015).

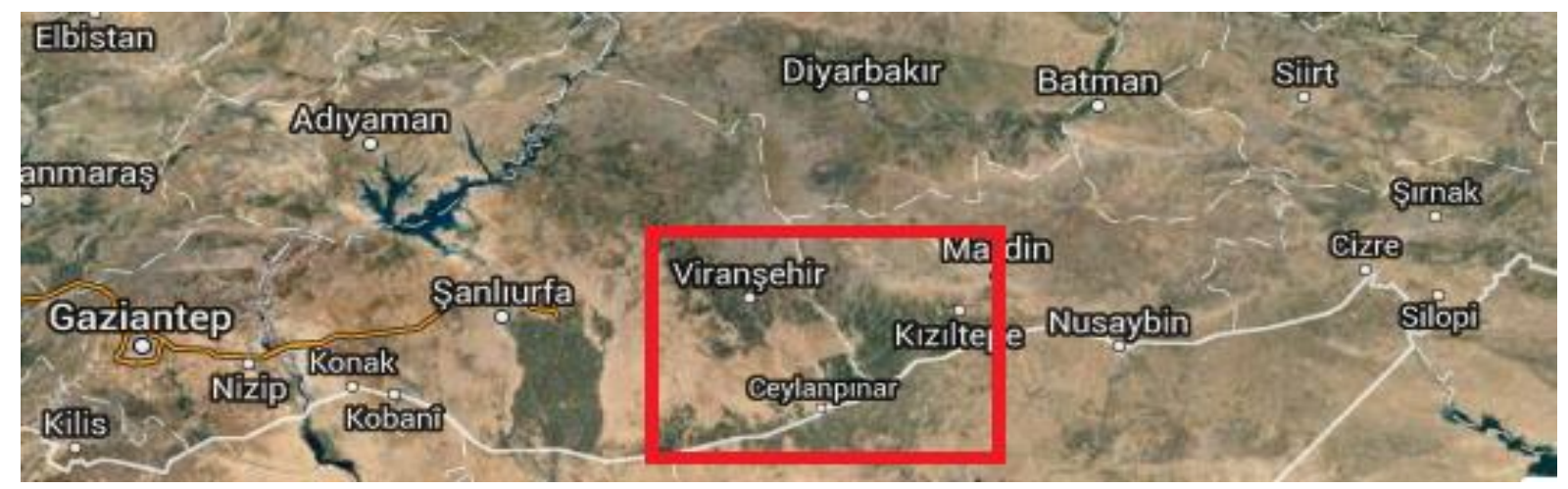

Figure 7.1 Most of the Area in the SAR where Bore Wells Are Excessively Being Used (Google Maps, 2017)

Many AEs in the SAR can access water through the pumped irrigation systems of the GAP despite their higher elevations than the water reservoirs, but then its costs are relatively higher due to associated electricity cost than for those relying on gravity-fed irrigation water (The State Hydraulic Works, 2012, p. 5). This is certainly true in the case of AEs in Bozova of Sanliurfa and Samsat of Adiyaman, which are supposed to pay electricity cost putting a strain on their finance (Erdil, 2014, July 24). Further, irrigation unions in Adiyaman could not pay electricity costs of irrigation water in many cases and ended up out of service (O16, personal communication, September 22, 2014; The Town Governorship of Samsat, 2013). The need for state intervention in such cases is clearly expressed by an official in the region (O16, personal communication, September 22, 2014): 
“[...] the water of the Ataturk Dam cannot be turned reversely, cannot be flowed to Adiyaman by the gravity, and energy is required to [do] this. In fact, how it can happen; if the state does a favour for farmers, in favour of farmers, in terms of the charge for water use, I mean, of charge for spending [electricity], our farmers can benefit from this. If she does not, farmer[s] cannot."

The agricultural enterprises affected, regardless of their size, abandoned the cultivation of high value added crops and turned to low value-added ones such as wheat and barley (F24, personal communication, July 7, 2015). The following discussion with farmers captures this (F24, personal communication, July 7, 2015):

"F24a: We had extracted water from the dam for some period. We had cultivated cotton for eight years and bankrupted. 40 billion Turkish liras ${ }^{96}$ of electricity bill were charged every year. [...] We have 3 or 5 flats and sold them. [...].

The interviewer: $[\ldots]$ there is [now] no irrigation water [supplied] to your current lands? F24a: No, there is not.

The interviewer: This is why you are doing rain-fed agriculture?

F24a: [...] the distance between us and the reservoir is 300 metres. [...] there is even no drinking water. [...] we benefit from neither water nor anything; the property submerged [in water reservoirs] was ours. [...] Over 1000 decares of land of our village were submerged. [...] some of us could put [the expropriation money] to good use but the rest could not.

F24b: They bought two or three flats.

F24a: They bought them, all right, but we wasted them for that [water pump].

The procurement of electricity and water would be subsidised for agricultural irrigation until 2001 (Güresinli, 2015, p. 66). This was left with the ARIP, and the electricity market was later privatised. The privatisation enabled the government to leave economic decisions about electricity to the market. However, privatised electricity distributors in Turkey receive a licence for certain regions, hence having monopolistic power in a certain regional market ("Elektrik Piyasasi Kanunu [The Act of Electricity Market]," 2013). For example, the Tigris Electricity Distribution Incorporated is the only service provider in six cities: Diyarbakir, Sanliurfa, Batman, Mardin, Siirt and Sirnak. The market for electricity production is indeed

\footnotetext{
${ }^{96}$ In 2005, Turkey introduced the new Turkish lira, equivalent to 1 million of the old Turkish liras. While speaking in their daily life, Turkey's people sometimes use the old Turkish lira. The electricity bill was 40,000 Turkish liras per year, which equals to around 9300 pound for 60 decares of land cultivated.
} 
limitedly competitive (The Energy Market Regulatory Authority, 2015, p. 22). And the unit price of electricity is higher in Turkey than the average unit price in the OECD countries (Aktan, 2006). In addition, the government does not subsidise the electricity use of agricultural enterprises or irrigation unions and does not guide or direct them in their decision-making process. The local representative of an agricultural non-governmental body (The Chamber of Agricultural Engineers in Mardin, 2012) summarises the case well:

"[...] Although [agricultural] producers approximately know the cost of all types of inputs, they cannot even guess the cost of electricity. While 3 or 5 thousand Turkish liras of a bill is charged for a year for the pumping well used in production, 25 or 30 thousand Turkish liras might be charged for the same well the following year. Moreover, it is said that some bills issued are equal to a hundred thousands Turkish liras. While this inconsistency is doing serious harms to producers, they are avoiding paying these bills, too. $[\ldots]$ that the price [per unit] of electricity is so expensive is another problem. The price of electricity produced in agriculture must be subsidised. Given that the Mardin [and Ceylanpinar irrigation] canals of GAP will be finished at a near future date, farmers are supposed to be saved from the burden of the accumulated debt."

However, the government has yet to intervene in the electricity market. Even worse, they have put agricultural support payments on hold to force agricultural enterprises to pay their electricity bill since 2014 (F5, personal communication, July 24, 2015, The Cabinet, 2014/6052). It was expected that this decision would force farmers to settle the issue with the electricity distributor. In reality, this pressure has acted as a disincentive for agricultural enterprises, which has resulted in reduction in the value added. Private electricity distributors have not made the required investments in the regional electricity grid. As a result, the electricity network frequently breaks down due to high electricity consumption, especially in summer. This electricity cut resulted in loss of agricultural values in the past years, approximately 115 million Turkish liras just for Mardin in 2010 (Irmak, 2012). ${ }^{97}$

Overall, the GAP investments in irrigation have the potential to enhance agricultural productivity; yet, these investments alone are insufficient. The study of Türkekul and Unakitan (2011) proves that the subsidisation of energy is required to foster agricultural productivity. However, the lack of subsidies, and the high cost of electricity as a result of the privatisation ostensibly hamper agricultural economic activities in the region. Note that the State Hydraulic Works is currently trying to find an innovative solution without harming

\footnotetext{
${ }^{97}$ It is around 26.7 million pounds. Power cuts also cause pump engine break downs. Its total cost to farmers in Mardin in 2010 was approximately 20 million Turkish liras or 465,000 pounds (Irmak, 2012).
} 
market dynamics; they are constructing solar panels for irrigation unions to decrease their energy costs for pumped irrigation (The State Hydraulic Works, 2015). The success of this initiative will determine whether any government intervention in the electricity market is required.

\subsection{Agricultural Commodity Markets}

The main aim of this section is to discuss how neoliberal policies towards and lack of government interventions in agricultural commodity markets have influenced AEs in the SAR.

For easiness, agricultural commodity markets will be addressed in two main categories: the fresh food market and the processed agricultural commodities market. We will address the relationship between main actors in these market within the boundaries of government agricultural policies and their adaptation to the international institutional framework. In doing so, we will show that neoliberal agricultural transformation in agricultural commodity markets has advanced at the expense of SAEs.

\subsubsection{The Fresh Food Market}

The crops sold in domestic markets for the direct consumption of urban dwellers are generally fresh fruits and vegetables. Some crops that are refined with simple treatments (e.g. drying and roasting) are also included in this model. Since Turkey has a high sufficiency in fresh fruits and vegetables (Turkish Statistical Institute, 2016a), some portion of these are exported to international markets, and tropical fruits, which gained popularity in the last two decades, are imported to be traded in domestic markets. Figure 7.2 points to the simplified model depicting the agricultural marketing network of fresh produce.

Fresh fruits and vegetables are secured in the domestic market through AEs growing these crops and importers bringing especially tropical fruits to supply to the domestic market. The total supply of fresh produce is eaten by consumers at their houses and restaurants to meet daily diet. What decreases the total supply is that merchants gather some of the produced fresh fruits and vegetables and trade in international markets to earn foreign exchange. What I learnt from my conversation with the local people is that most of the fresh vegetables produced in the region are consumed within its boundaries. However, its historical heritage, and its culture surrounding food have attracted many tourists to the SAR since the armed conflict ended. This adds to the total demand of the fresh produce cultivated in the region. 
AEs could have been expected to get higher prices, but some practices of agricultural liberalisation have not allowed this.

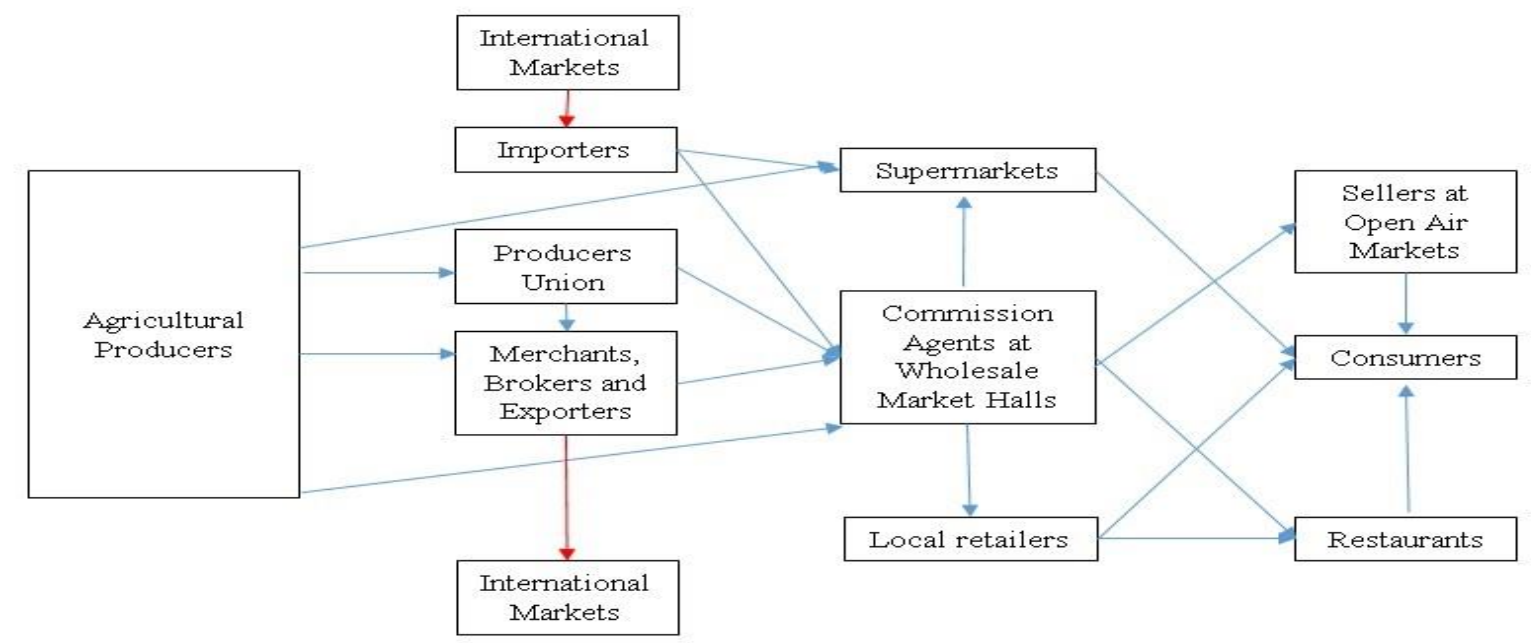

Figure 7.2 The Main Supply Line of Fresh Fruits and Vegetables

Although Turkey has adopted the agricultural trade liberalisation imposed by the Uruguay Round Agreement, it has continued to protect raw agricultural products, including fruits and vegetables, with higher tariff rates without violating the agreement. The exclusion of raw agricultural products from the EU Common Custom Tariffs also provides a room for the government to protect the AEs growing them (the OECD, 2011, pp. 50-51). According to the OECD (2016b, p. 23), the Turkish trade regime can be considered liberal given its tariff structure; yet, several factors such as standards, procedures, 'mutual recognition agreements', and fees and charges, etc. are rendering Turkey more restrictive in international trade than most OECD countries. As a result of this hybrid approach to international agricultural trade, average agricultural prices received by AEs in Turkey have turned out to be $20 \%$ higher than world prices in 2015 (the OECD, 2016a, p. 123). Still, this is lower than the price levels in the 1990s. After the ARIP, the agricultural prices received by farmers have dramatically dropped due to the lowered international trade barriers, leading to the income loss of AEs (M. Öztürk, 2012, pp. 94-95).

One of the important changes made within the ARIP engendered the exclusion of agricultural sale cooperatives (ASCs) and unions (ASCUs) at the expense of AEs. This policy change was to cease governmental financial support to them as they had purchased crops from their members at a loss. The most important factor behind the financial loss was that the floor prices had been set higher than market prices, having inevitably created incentives to 
producers. Another important factor was that the sale cooperatives were forced by the politically-motivated government to get the excessive volume of crop purchases (Oral, 2015a, p. 330). Worse, storage costs and the sale of crops to merchants and industrialists at a loss because of overstuffed inventories heavily harmed their economic efficiency (Oral, 2015a, p. 330). These cooperatives therefore formed a heavy financial burden on the public budget.

ASCUs were restructured with the ARIP and compelled to offer prices to their members without compromising their competitiveness (M. Öztürk, 2012, p. 90), to obtain financial resources from the market (the OECD, 2011, pp. 42-43). Today, the main problem of agricultural producers in the SAR is that they are heavily dependent on merchants in the commodity market, so unable to set prices in the absence of sales cooperatives and the collective action they had provided before. The ASCUs that were operating in the SAR in the 1990s are seen in Table 7.7.

\begin{tabular}{|l|c|l|}
\hline Cooperative Unions & Current Status & \multicolumn{1}{|c|}{ Agricultural Commodities } \\
\hline Guneydogubirlik & Closed & Pistachio, Red Pepper, Red Lentil, Raisins, Olive and Olive Oil \\
\hline Gapbirlik & Open But Not Active & Cotton, Lentil, Pistachio, Soy Bean, Red Pepper, Raisins, Maize \\
\hline Cukobirlik & Limitedly Active & Cotton, Groundnut, Soy Bean, Sunflower, Kanola \\
\hline
\end{tabular}

Table 7.7 The Cooperative Unions in the SAR, Their Current Status and Their Areas of Operation

The Gapbirlik is officially still active but in reality it is not. As we will mention in the next section, the Cukobirlik is active but on a limited level. The Guneydogubirlik went into liquidation. Instead of ASCUs losing their power in agricultural marketing, producers unions (see Table 7.8) have been encouraged by the government across the country. Affiliated with a centre union of producers union as to crop groups, these unions are mostly organised on town-level, involving a small group of farmers. Most of them have succeeded in reaching export markets, thereby getting higher prices from brokers, merchants and exporters (Demir Kaya, 2016a; Parlak, June 8, 2018) and even guaranteeing their future sales through contracts (Demir Kaya, 2016a). The unions are, however, not connected with each other and sometimes even compete with each other, and thus most of them cannot enhance their bargaining power to get even higher prices from merchants or brokers. ASCs, nevertheless, would cover most of the farmers engaging in the production of a certain crop type, collect most of them through subsidised purchases and sell them to merchants at higher prices thanks to their monopolistic status. 


\begin{tabular}{|l|c|}
\hline Cities & Crop Types \\
\hline Adiyaman & Grape; Hard Shelled-Fruits; Organic Fruits; Milk; Meat \\
\hline Batman & Strawberry; Grape; Pistachio; Aquaculture Products; Milk, Meat \\
\hline Diyarbakir & Grape; Cotton; Grains; Organic Grains; Organic Fruits; Milk, Sericulture; Honey; Vegetable \\
\hline Gaziantep & Cherry; Milk; Meat; Egg \\
\hline Kilis & Organic Olive; Vegetable \\
\hline Mardin & Olive; Grains; Cherry; Milk; Honey; Meat \\
\hline Sanliurfa & Natural Flower Bulb; Milk; Pepper; Pistachio; Honey; Meat \\
\hline Siirt & Pomegranate; Honey; Pistachio; Milk \\
\hline Sirnak & Grains; Milk \\
\hline
\end{tabular}

Table 7.8 Crop Types in Which Each Producers Union Carries Out Agricultural Marketing Operations (The General Directorate of Agricultural Reform, 2017)

The Guneydogubirlik is an instructive case. Its former general directorate, Ökkeş Kıroğlu, blames politicians and the authorities in the chamber of commerce and the commodity exchange in Gaziantep for the closure of the Guneydogubirlik:

“[...] Now, producers are in a terrible state, especially in pistachio, lentil, pepper and grape. They [politicians and the authorities] guessed that after the cooperative got closed, they would make a lot of money. Those who are earning from this business now are just hoarders. [The importance of] its absence has been come out. When the cooperative exists, it would release the commodity to the market if it disappeared. [...] the price would not rise. [...] the market would be stabilised itself. If it was too much in the market, the cooperative would purchase it. Then [...] the price would come to stability. Everyone would have confidence. Producers would sell their products well. The shopkeepers would get their product well. Hoarders would not earn (Kınacılar, 2018, 3 August)."

Hoarders here refer to a group of merchants who own inventories and adequate financial resources to make economic operations in the market to maximize their profits. They can speculate in the market or easily benefit from price fluctuations where there are no well functioning cooperatives. As SAEs and MAEs have no capability to store and process, they do not have this bargaining power in agricultural marketing networks. This case is also applicable to the other regions of Turkey for the sale of other fruits and vegetables, with merchants and supermarkets being behind the lower prices received by producers and higher prices paid by consumers (Lemeilleur \& Codron, 2011) (see Table 7.9). The more merchants 
get involved in conveying fresh produce to urban areas, the higher the prices paid by urban consumers owing to transportation costs.

\begin{tabular}{|c|c|c|c|c|c|c|c|}
\hline Crops & $\begin{array}{c}\text { The Prices } \\
\text { Received } \\
\text { at Farm Gate } \\
\text { (TL/Kg) }\end{array}$ & $\begin{array}{c}\text { The Prices at } \\
\text { Wholesale } \\
\text { Markets } \\
(\mathrm{TL} / \mathrm{Kg})\end{array}$ & $\begin{array}{c}\text { The Prices at } \\
\text { Open Markets } \\
(\mathrm{TL} / \mathrm{Kg})\end{array}$ & $\begin{array}{c}\text { The Prices at } \\
\text { Supermarkets } \\
(\mathrm{TL} / \mathrm{Kg})\end{array}$ & $\begin{array}{c}\text { The Price } \\
\text { Differential } \\
\text { Between Farm } \\
\text { and Wholesale } \\
\text { Markets }\end{array}$ & $\begin{array}{c}\text { The Price } \\
\text { Differential } \\
\text { Between Farm } \\
\text { and Open } \\
\text { Markets }\end{array}$ & $\begin{array}{c}\text { The Price } \\
\text { Differential } \\
\text { Between Farm } \\
\text { and Supermarkets }\end{array}$ \\
\hline Apple & 1.31 & 3.06 & 3.33 & 5.21 & $133.59 \%$ & $154.20 \%$ & $297.71 \%$ \\
\hline Aubergine & 0.94 & 1.49 & 2.17 & 2.77 & $58.51 \%$ & $130.85 \%$ & $194.68 \%$ \\
\hline Watermelon & 0.48 & 0.76 & 1.00 & 1.34 & $58.33 \%$ & $108.33 \%$ & $179.17 \%$ \\
\hline Tomato & 1.58 & 2.10 & 2.83 & 4.08 & $32.91 \%$ & $79.11 \%$ & $158.23 \%$ \\
\hline Cucumber & 1.50 & 1.79 & 2.33 & 3.08 & $19.33 \%$ & $55.33 \%$ & $105.33 \%$ \\
\hline Pistachio & 40.00 & N/A & 70.00 & 82.80 & N/A & $75.00 \%$ & $107.00 \%$ \\
\hline Raisin & 7.30 & N/A & 12.00 & 13.60 & N/A & $64.38 \%$ & $86.30 \%$ \\
\hline Pepper & 1.86 & 2.24 & 3.00 & 3.45 & $20.43 \%$ & $61.29 \%$ & $85.48 \%$ \\
\hline Onion & 1.75 & 2.43 & 2.67 & 3.05 & $38.86 \%$ & $52.57 \%$ & $74.29 \%$ \\
\hline Beef & 29.04 & N/A & N/A & 47.13 & N/A & N/A & $62.29 \%$ \\
\hline Lamb & 39.43 & N/A & N/A & 63.50 & N/A & N/A & $61.04 \%$ \\
\hline
\end{tabular}

Table 7.9 The Prices of Fresh Agricultural Commodities at Different Nodes of the Agricultural Marketing Network in 2018 (Turkey Union of Chamber of Agriculture, 2018)

Most households and restaurants prefer to acquire their fresh food from sellers at open markets or local shopkeepers, who secure their products from whole markets. At wholesale markets, commission agents add a 3-8\% of commission to their prices (Atasoy, 2013; Lemeilleur \& Codron, 2011). Their intermediary position is guaranteed by law in return of tax, that is, the producers who do not sell their products to exporters and agro-food industries must sell them to wholesale markets if the volume of sale per day is under the level set by local municipalities (Atasoy, 2013; Lemeilleur \& Codron, 2011).

Supermarkets are another major actor supplying fresh produce to consumers. They are increasing their share in the retail market in recent years (The Competition Authority, 2011, p. 6), but their sales of fresh fruits and vegetables compose a small portion of the total (Lemeilleur \& Codron, 2011) because of their higher price policy (see Table 7.9). One of the important cases in the organised retail sector is that conservative capitalists in Anatolia associated with the ruling party have increasingly invested in this sector, which causes competition with secular and international capitalists and the resultant intensification of market-based relationships in the food sector (Atasoy, 2013). The outcome is that small producers are increasingly developing their ties with supermarkets in value chains (Atasoy, 2013). As I observed, while local supermarkets are spreading across urban areas in the SAR, 
a very small group of farmers directly sell their fresh produce to them, most sell at local open markets or to agents in wholesale markets.

It is clear that merchants and brokers appropriate the agricultural surplus generated by fruit and vegetable producers under free-market conditions. Though they are complaining about the intermediary positions of merchants and brokers, they despairingly admit that this traditional supply chain will not change in the near future. They do not receive any price support, and there is no market intervention by any board. The neoliberal agricultural policies certainly support merchants and supermarkets at the expense of producers and urban wage earners. O35 (personal communication, August 6, 2014), an official expert on marketing in the MOAF, elaborates on the problems of producers in trading their products:

O35: Those who got out of the [whole sale] market feel impelled to engage in systems like district-level open markets [or] things in between like alternative marketing systems. It is because they are not able to access national markets. It is because getting products to over there is a must for accessing [national markets], [and] paying taxes is required. For example, you cannot sell products without getting involved in the whole sale market [...]. In the whole sale market for fruits and vegetables, the share of merchants and brokers is about $70-80 \%$, farmers $5 \%$ and farmer organisations $2-3 \%$. What does it mean? In the market of agricultural products [or] of fresh vegetable and fruit, merchants and brokers play a dominant and prevalent role. The price of tomatoes [per kilogram] which is 50 kurus $^{98}$ or 1 lira at the farm increases by two or three times when [buyers go through] checkout in the whole sale market. When they arrive at Istanbul, their price goes up by 4 or 5 times. [...] the share of producers in the [total] value-added [...] is low; it is far lower for small producers. [...] large scale ones can directly reach to supermarkets and markets through their means. [Yet,] small producers are to sell them to one or several intermediaries. [...] This is not a sustainable and competitive structure. Today, not only Turkey but also FAO are doing research for not losing smallholders or family farmers by addressing how their integration with the market will take place. [...] Another question is that there are supermarkets in our [country] [...] like Aldi or Tesco in the Europe. They are disintermediating [merchants and brokers] and directly buying products from producers and farmlands but still tomatoes for 50 kurus [for agricultural producers]. They are claiming the profit of intermediaries and still have a negative effect on producers. $[\ldots]$ while the retail sector is growing, there is no improvement in [economic] welfare of producers.

${ }^{98} 100$ kurus is equal to 1 liras. 
Where real agricultural prices in Turkey have nearly remained constant since 2001 (A. Y1lmaz \& Ar1, 2013), intermediary actors have increased their profit margins and have forced agricultural producers to acquiesce to reductions in their profit margins (Baydur, 2015).

In the hope of getting higher prices, some of AEs directed their resources to organic crop production, preferred by the urban middle class (M. Öztürk, Jongerden, \& Hilton, 2014). In fact, organic farmers in the SAR have received higher prices than non-organic farmers but not to the expected level (Monis et al., 2012, pp. 29-31, 41). As O9 (personal communication, September 30, 2014) stated, the subsidy for organic farming is given by the government to encourage agricultural producers; yet, it has remained low for SAEs, and generally favoured LAEs, since it is granted subject to land size. Another way encouraged by development agencies and the GAP-RDA was to produce local agricultural products having genuine qualities that are recognised and certificated by the EU as products with geographical indication, offering protections, so higher prices, to agricultural producers (B. Aslan \& Demir Kaya, 2017).

We mentioned that urban consumers have been the other actors paying for the costs of agricultural policies, and worse, they have been confronted with decreases in real wages since 2001 (A. Y1lmaz \& Ar1, 2013). They are still paying higher prices for agricultural commodities than international prices, but this has gradually been reduced as a result of agricultural liberalisation. Domestic agricultural prices at the farm gate were $60 \%$ higher than international prices in 1999, 29\% in 2007, 22\% in 2013 and 32\% in 2016 (The Organisation for Economic Co-operation and Development, 2018). It shows that the loss of urban consumers' wages has been alleviated with domestic agricultural prices getting closer to international market prices.

Why has the government allowed producers to be protected from international competition by not designing policies that would converge domestic and international agricultural prices? According to Keyder (2014, p. 208), 'most of the agricultural producers in Turkey are not able to compete with the world regarding productivity for the reasons of the agronomic qualities of soil, the technology used, the scale of enterprise and climate.' The issue points to structural problems. Agricultural liberalisation and market dynamics have apparently not overcome these problems. And the rise in uncultivated land implies that the convergence of domestic and international prices would have brought devastating results for agricultural production. 
It should be noted that fruit and vegetable producers receive higher prices than field crop producers as they have comparative advantages in international markets. This advantage pertains to the cultivation of fruit and vegetable types involving the peculiarity of Turkey and Mediterranean geography and climate. Despite high sufficiency in their cultivation, their export decreases the level of the supply to the national market, so keeping these prices relatively high. This allows the government not to give premium payments based on output to fruit and vegetable producers. Except for input subsidies, fruit and vegetable producers competitively operate under free market conditions.

All the effort to increase agricultural productivity are greatly exploited by merchants and middle- and large-scale capitalists at the end of the day, which form a strong political base of the ruling party at regional and national levels.

\subsubsection{The Processed Agricultural Commodity Market}

Processed agricultural commodities enter domestic markets via three channels: domestic and international processors and importers (see Figure 7.3). International agro-processors do not have any weight in the industrial production of the SAR but in the regional consumption through their vendors and through the domestic importers merchandising their products to supermarkets and local retailers.

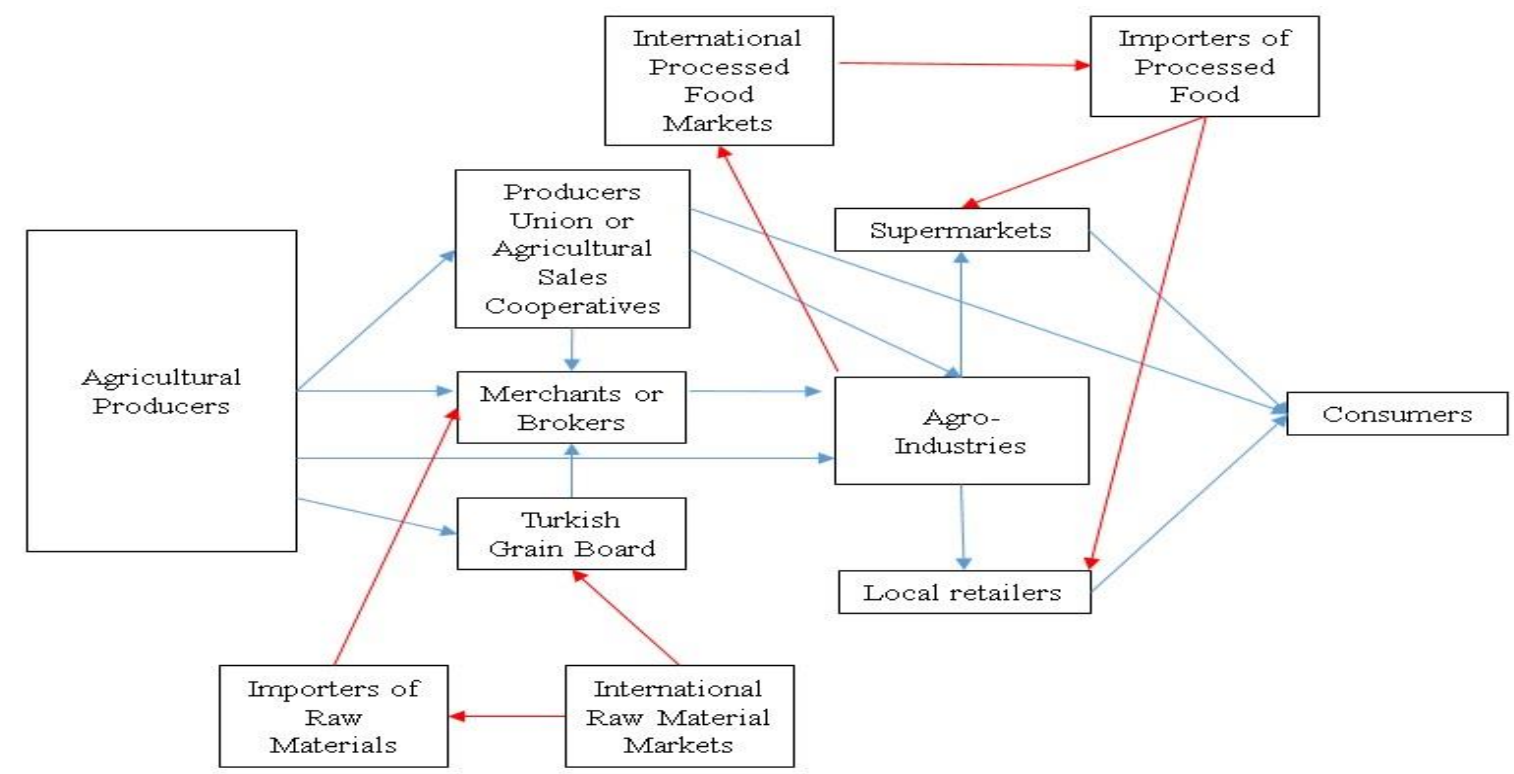

Figure 7.3 The Main Supply Line of Agricultural Raw Materials and Processed Food in the SAR

Both globalisation and trade liberalisation have created a suitable environment for the international agro-industrial companies and importers to expand their commercial operations 
across the world. In this sense, Turkey has gone beyond what is expected regarding international trade, with the adoption of the EU Common Custom Tariffs. For example, Turkey's protection of processed agricultural commodities has remained far lower than the level imposed by the Uruguay Round Agreement (the OECD, 2011, p. 50). Varieties and the range of brands in food, beverages and textile products have therefore expanded more. The organised retailing sector has long been supported by the government creating incentives, loan concessions and exemptions in order to diminish the weight of unrecorded commerce leading to loss of tax income (A. A. Koç et al., 2007). They therefore increased the share in the fast-moving consumption good sector from around $31 \%$ in 2004 to around $51 \%$ in 2011 (The Competition Authority, 2012, p. 5). The upsurge in the use of credit cards and consumer loans after mid-2000s thanks to decreasing interest rates and flourishing future expectations (Mazibaş \& Tuna, 2017) has helped households to grow their consumption with user-friendly cooking and storing devices, fast-moving consumption goods, fast-food and apparels (A. A. Koç et al., 2007), ${ }^{99}$ justifying neoliberal policies in the eyes of urban people in spite of decreasing real wages.

Meanwhile, international agro-processors have bolstered their partnerships with domestic large-scale capitalists in west Turkey, which help them fully exploit potential benefits from their intellectual property rights such as patents and brands (Yenal, 2014, pp. 113-126). This development marks the intensification of the existing surplus transfer mechanism from the SAR to west Turkey, of which the urban areas have densely been populated in the last two decades, and to abroad. As I observed, the organised retailing sector has a place in the city centres but hardly in the towns, except for local ones.

One of the important phenomenon is the increasing share of discount supermarkets in the retailing sector, which sell products with their own private labels and of little-known brands (The Competition Authority, 2012, pp. 6-8). Conservative Anatolian capitalists play an important role in manufacturing processed food for such supermarkets through subcontracting and also serve as subcontracted manufacturers for international and national textile companies with popular brands (Hosgör, 2011).

How is the position of agro-industries of the SAR in such a competitive environment? The competitiveness of the agro-industries in the SAR, mostly at small and medium scales, tend to be less than those in west Turkey because of several reasons. First, their financial and

\footnotetext{
${ }^{99}$ Around $25 \%$ of total household expenses in Turkey are made for food, beverages and tobacco products (KMPG Turkey, 2018, p. 8).9
} 
technical abilities of marketing their products to the national market are limited, and therefore they generally produce commodities as subcontractors yielding lower profits (N9, personal communication, May 11, 2015). Another reason is that they have technical and financial barriers to smoothly proceed from the level of simple processing to advanced levels. For example, the SAR is ranked first in cotton production; ginneries have spread across the region, but the industries of cotton spinning, dying and textile have remained nascent (Deniz, 2010, p. 23). An expert in the Chamber of Commerce and Industry at Diyarbakir, N9 (personal communication, May 11, 2015) pointed out that grains are processed to produce flour, bran and bulgur but rarely to make pasta and biscuits, and that agro-food products are commonly packaged and branded in other regions. As N9 stated, capitalists outside the region (conservative Anatolian capitalists) get into agro-manufacturing to take advantage of lowcost raw materials and low-paid workers. In addition, local capitalists generally invest in agro-processing industries, composed by Kurdish capitalists and conservative capitalists from different ethnic groups. The large-scale secular and conservative capitalists have engaged in the sectors requiring high capital levels such as retailing, cement production, mining and energy in the last two decades.

In an effort to overcome these problems, agro-industrial companies are financially and technically being assisted by the government and international organisations in line with the development strategy of the GAP, and by the EU with a view to adapt Turkey's agriculture to the accession conditions of the Union. Conservative local capitalists, thanks to their political rapport with the ruling government, are obtaining the required support from the government. Again, the Kurdish capitalists have also been backed in the same way, as a part of the government strategy that aims to strengthen ties with the loyal Turkish and Arab-origin capitalists and to assure the economic dependency of Kurdish capitalists to the state. According to N9 (personal communication, May 11, 2015), an official in Diyarbakir Chamber of Commerce, such capital owners are receiving grants, tax exemptions, loan concessions through different schemes to make investment in the sub-sectors they have comparative advantages, such as industrial feed, packed milk products and meat, packed pulse products, edible oil, flour, bakery products, ginning, irrigation equipment, etc. ${ }^{100}$

The number of food processing firms in the SAR has increased fourfold between 2002 and 2017 (from 294 in 2002 to 1198 in 2017) thanks to these financially backed investments, and

\footnotetext{
${ }^{100}$ In this way, the total value of annual private industrial investments in the SAR that are financially supported by the government grew by nearly 18 times from 451 million Turkish lira in 2002 to 8.5 billion Turkish lira in 2017 but $69 \%$ in Turkey (The GAP-RDA, n.d.-a).
} 
the number of firms in textile, apparel and leather sectors raised by nearly 1.5 times (from 511 in 2002 to 1227 in 2017) (The GAP-RDA, n.d.-b). ${ }^{101}$ The total value of industrial export and agricultural export have been mounted by 12.5 and 11.8 time respectively since 2002, recording around 2.6 billion dollar in foreign trade surplus (The GAP-RDA, 2018, pp. 39-40). In the period between 2004 and 2017, the SAR's industrial economy has annually grown $(16.22 \%)$ more than Turkey's (15.13\%) in current prices (Turkish Statistical Institute, 2018a).

Agro-industrial companies sell their products to consumers through supermarkets and local retailers and additionally export them mostly to Middle-East countries. As such, compared with supermarkets and merchants, agro-processors tend to operate with greater profit margins (Dağlı \& Eker, 2016; Kazak, 2018; Turkish Exporters Assembly, 2016, p. 27). ${ }^{102}$ Therefore agro-processors are expected to be the most prominent beneficiaries of agricultural production in the SAR.

The owners of agro-industries secure raw materials from the crops of their agricultural land as well as the merchants and brokers who acquire them from agricultural producers at different scales. Again, some owners of LAEs can directly sell their crops to manufacturers in the region, receiving higher prices than SAEs and MAEs. To a large extent the Turkish Grain Board and producer unions and Cukobirlik to a lesser extent also become involved in the provision of raw materials (see Figure 7.3).

\subsubsection{Cooperatives}

As mentioned earlier, ASCUs were re-organized after the ARIP, turning their processing facilities into corporations as a part of privatisation (Oral, 2015a). Oyan (2000 cited in Oral, 2015 , p.331) criticised at that time that those policies would undermine industrial and commercial capacities of the ASCUs, so deteriorating the bargaining power of AEs against other actors in the market. The Guneydogubirlik is an instructive case. Its former general directorate, Ökkeş Kıroğlu, emphasizes that the factories of the Guneydogubirlik processing various crops were closed and sold for close to nothing, and AEs have thus been doomed to failure in the favour of merchants (Kinacilar, 2018, 3 August).

\footnotetext{
${ }^{101}$ All the mentioned agro-industrial sectors account for around $57 \%$ of total industrial firms in the region. Note that about $66 \%$ of the total industrial firms agglomerate in only two cities, Gaziantep and Sanliurfa (The GAPRDA, n.d.-b).

102 It must be noted that there are disparities between firms at various scale regarding profit margins. As expected, economies of scale prevail in Turkey's food processing sector, that is, the larger the scale of a firm, the greater the profit margin (Dağlı \& Eker, 2016).
} 
As Karli and Çelik (2003) point out, financial problems after the restructuring drove the cooperatives in the SAR to withdraw from the market. The Cukobirlik has about 15,300 members in the SAR, ${ }^{103}$ but what I learnt from my fieldwork was that most of those members do not actively work with the cooperative. For example, the total number of the members at the central district of Sanliurfa is about 3,000 on paper. Yet, only 100 to 200 cotton producers, and mainly large and medium scale AEs, actively collaborate with the Cukobirlik. As the manager of the Cukobirlik at Sanliurfa city centre (N2, personal communication, April $29,2015)$ expressed, the vast majority of cotton producers gave up working with the cooperative since the withdrawal of state funds thwarted the operational effectiveness of the cooperative, and only the agricultural producers which harvest low quality cotton are now willing to bring their products to the cooperative. The Cukobirlik has long had difficulties to repay the debt borrowed during the restructuring period (Çavdarc1, February 23, 2017). The cotton purchased by the cooperative therefore declined from around 208,500 ton in 1998/99 to around 82,700 in 2007/2008 (TGNA Inquiry Committee, 2008, p. 272), which resulted in their sale operations only concentrating on areas outside the SAR. According to Cahit Ari, a deputy in Turkish Grand National Assembly (TGNA):

[...] if we especially look at [the issue] with regard to cotton, the cultivated areas for cotton as the most important raw material for textiles and the oil industry declined from $7,210,770$ decares in 2002 to 5 million decares in 2017. A decrease of $30 \%$ has come up from 2002 to 2017. The import policies have been maintained in cotton, too; the insufficiency has been tackled through import. Consequently, the import of cotton has rose by $56.25 \%$ between 2003 and 2017. In this context, there is great importance in increasing efficiency of TARIS, Cukobirlik and Antbirlik. Additionally, the support [payment] given to cotton production is not adequate (TGNA Directorate of the Minutes Services, November 16, 2018, p. 75).

Turkey has a comparative advantage in textiles. In 2015, Turkey ranked eighth globally and third among European countries with regard to the production of clothing. The country is in the group of top-ten exporter countries globally in textiles (The Ministry of Economy, n.d). Despite the high competitiveness in this sector, the lack of subsidies, the absence of cooperatives in marketing, and the lower prices for cotton have created disincentives to AEs in Turkey, rewarded AEs abroad and resulted in losing foreign currency. The fact that the

103. They also show that Cukobirlik had over 63,000 members at its peak but now only has 15,000. 
SAR accounts for around $57 \%$ of Turkey's total cotton production (Turkish Statistical Institute, 2017c) indicates that AEs in the region have suffered.

Where the neoliberal agricultural policies have trivialised the cooperatives in the SAR, producers unions have sprouted to some extent as mentioned earlier. Some of them have been processing and packaging the crops they collect for a few years, and some are still constructing the required facilities through national and international financial and technical assistance. We shall address the case of Kilis Organic Olive and Olive Oil Producers Union in the following sections, as an example of a success story.

\subsubsection{The Turkish Grain Board}

The Turkish Grain Board was responsible for purchasing grains and pulses at the declared prices when required, monitoring the national reserve and assuring the required stock for possible shocks in demand or supply (M. Öztürk, 2012, p. 94). Until 2001, the Board had generally relied on public funds and the write-off of debts by the government to curb overproduction and sharp contractions in prices (the OECD, 2011, pp. 43-44; M. Öztürk, 2012, p. 94). It was remodelled to better handle market fluctuations and sustain the stability of the grain market (The World Bank, 2009, pp. 1, 4, 9). In this regards, the Board ceased preventing dramatic declines in grain prices owing to overproduction, lifted import barriers, started to give lower prices to farmers as lessening purchases and set the minimum purchase quantity at the expense of SAEs (M. Öztürk, 2012, p. 94). The main aim was eventually to lower the subsidised prices to the level of world prices.

Modernising its labs, facilities and equipment after $2001^{104}$, the role of the Board in the market is now to alleviate sharp market fluctuations with price interventions. O26 (personal communication, September 26, 2014), an official in Turkish Grain Board in Diyarbakir clarified this policy:

O26: When you would look at [the data of] some year in the past, we totally purchased 360,000 tonnes of wheat and 275,000 tonnes of maize. [...] but when we look at [the data of] 2014, we did not purchase even one kilogram of wheat.

Interviewer: Why not?

O26: The intervention purchase price was not declared.

Interviewer: Why was it not declared?

\footnotetext{
104 The modernisation of facilities, labs and equipment of Turkish Grain Board should be considered as an attempt to innovatively increase institutional capacity. For example, the pricing of grains became a scientific endeavour using the modern equipment evaluating the nutrient and quality values.
} 
O26: Assume that as merchants purchase wheat from the market for 800-900 liras per ton, if the price we declare was 700 liras, we would dismay producers [...]. Last year, $[\ldots]$ the purchase price was 635 liras. We will increase it by the inflation rate, $8 \%$. When you added it [to the intervention price], it accounts for approximately 700 liras. If you declared it as 700 liras and the wheat price was 800 liras, it would mean that your policy is against producers. It would mean that you do not implement your mission [properly]. We have a mission to protect both producers and consumers. It would mean that [...] you side with industrialists. If we declared it as 700 liras, that price of 800 liras immediately would decrease to 650 liras. [...] Why? This is because Turkish Grain Board would cut official expenses from the declared price [...]. All of them account for 5\%. [...] The market [actors] would immediately calculate it and [declare,] "I am purchasing [wheat] at 660 liras."[...] [Additionally], when you get wheat to the Board, there is a transportation cost [to pay]. [...] [Merchants] would tell them, "Do not go run in circles, brother, and get your 650 liras. I will come to your farmland to get your products". [...] When the price drop to 650 liras, if the Board was not be able to gather enough wheat [from producers], - here is so important- merchants would increase the wheat price to 900 liras three months later [at the expense of industrialists]. If the Board did not have enough wheat in hand, she would import [wheat] or sell her stock, in order to protect consumers [and industrialists].

If we look at what the official said, we might conclude that the price regulatory mechanism is working smoothly in favour of all actor groups in the market. However, Ali Ekber Yildirim (May 27, 2015), a journalist writing about agriculture, points to the trouble on agricultural producers posed by the Board's policy:

The production [of wheat] that amount to 22 million 500 thousand tonnes in 2013 fell to 19 million tonnes in 2014. Additionally, the quality of the products was not at the desired level. But the price increased because of the decreased production. The Turkish Grain Board did not declare any intervention price as "the price was high".

The case is so different this year. Both production and quality are high.

[...] The concern of the producer is that the price of 820 [Turkish] lira [per ton] could decrease as long as the [total] yield increases. [...] The wheat producer argue that costs have risen too much, and a decrease in price would negatively affect the next year's production.

The date of the announcement of the price by the Board is underlined here. When costs rise year by year, any drop in the price could easily bankrupt the agricultural producers with 
financial vulnerabilities. They, therefore, call for the Board intervening in the market to keep the price up. Indeed, many SAEs complained during the fieldwork about the price policy conducted by the Board. A smallholder cultivating grain in Adiyaman, F24 (personal communication, July 7, 2015) provides an illustrative case:

We sell barley to merchants in the [local] wheat market. [...] Will we wait for the state! [If] we have a harvester reaped [barley], then we pay fee for the harvester. For the debt [owed] for fertilizer, we pay [back the required] money. [...] If the state had offered us a price, we would not have brought [to merchants]. I mean we would have waited. They [the Board] are now purchasing [grains], [but] I have nothing. [...] I obtained [loan] from a fertilizer seller. He added 250 liras [to the total payment] as interest. I had to [do this], no way.

The late announcement of purchase prices results from the Board monitoring the market for price stability; the officials do not intervene in the grain market until they have assessed if grain prices would economically harm consumers, producers or industrialists. As discussed earlier, SAEs mostly obtain inputs by borrowing from input sellers, merchants and broker. After all, they are supposed to pay back loans with interest just after the harvest. It means that they are unable to take the advantage of the price that will later be declared by the Board, thus selling their crops to merchants at lower prices and failing to fully derive potential profits (Ihlas News Agency, July 6, 2017). When prices increase within the season, merchants get the extra returns.

\subsubsection{Agricultural Producers versus Merchants and Agro-Industries}

We need to understand market-based relationships between agricultural producers, merchants and agro-industries within the context of support policies. As mentioned, subsidised purchases were eliminated with the ARIP reshaping cooperative and the Turkish Grain Board. The premium payments subject to the sale of certain crops were later introduced so that the supply of agricultural raw materials could be secured by agro-processors.

\section{The Premium Payment}

The market price support policy is essentially based on the deficiency or "premium" payment in Turkey, which is given to AEs as a payment per unit, without intervening in the market price and the amount of the supply. The government actually aims for AEs to continue their crop-specific production through this policy. OECD (2011, p. 112) criticizes the Turkish government that the deficiency payments are 'potentially the most distorting and inefficient forms of support in transferring income to farmers' and are supposed to be replaced by 
decoupled policies such as the DIS payment, which have 'no or minimal impact on production and trade' (OECD, 2006, p. 9). The DIS, however, did not yield the expected results and resulted in a decrease in the cultivated areas, as shown before.

In order to protect agricultural producers against a decrease in the prices of the selected crops and to promote self-sufficiency (The MOAF, 2016; Turkish Statistical Institute, 2016a) ${ }^{105}$, the government pays the premium payment as to the amount of the crop sold. The crops included in the premium payment policy framework are grains, pulses, oil seeds, maize and cotton, which are seen by the government as strategic crops (The MOAF, 2013, p. 51). As it is, LAEs can reap far more benefits from the premium payment than SAEs through their relative advantages in land size.

The production of those crops is vital for the export industry. For example, Turkey is ranked fourth in pasta production and third in its export (The Ministry of Economy, 2017, pp. 2-3), fourth in bulgur production and first in its export (Ankara Commodity Exchange, 2016), fifth in the export of bread and baked products (Ankara Commodity Exchange, 2018) and finally first in the export of flour (Turkish Flour Industrialists' Union, 2012, p. 16). Middle Eastern and African countries are the main consumers of these Turkish products; for example, around 45 per cent of Turkey's exported flour is purchased by Iraq (Turkish Flour Industrialists' Union, 2015). Given its geographical position, the continuation of producing those crops and of the premium payment are of critical importance for agro-industries in the SAR. True, about 78 per cent of total value of SAR's export relies on agriculture and agro-processing sectors (The Exporter Unions of the South-eastern Anatolia, 2016).

Securing agricultural raw materials is essential for the competitiveness of the agro-industries. Recall, the cultivated areas of Turkey have declined by 3 million ha, and many AEs relying on rain-fed farming have withdrawn from the cultivation of field crops and kept their lands idle. In this case, the premium payment is deemed an effective tool to make AEs to proceed with the production of agricultural raw materials. Yet, the premium payments have remained largely inadequate to fulfil the commitment to decreasing the share of agricultural support in GDP. For example, the premium payment for wheat has been 50 Turkish lira (TL)/ton since 2007 despite raising inflation rates; the premium for barley was $40 \mathrm{TL} /$ ton in 2007 but just 50

\footnotetext{
${ }^{105}$ According to the Turkish Statistical Institute (2016a), wheat hit rock bottom in 2008, that is, its sufficiency rate was 94.5 per cent in 2008. The sufficiency level of maize has never exceeded 93.2 per cent in the period between 2000 and 2015. Beans dropped to its lowest sufficiency level, 71 per cent, in 2007. Red lentil sometimes reached high levels of over-sufficiency but dropped drastically to $45.2 \%$ in 2008 . Green lentil production diminished greatly despite the premium payments; its sufficiency was 39 per cent in 2014. Unlike most field crops, fruit and vegetables have almost always maintained their sufficiency level over 100 per cent.
} 
TL/ton in 2018 ("The Premium Payments in 2008," 2008; The Ministry of Agriculture and Forest, 2018).

Gül Yavuz, Miran, Gürer, Yürekli Yüksel, and Demir (2016, p. 67) argue that the wheat and maize prices are key factors in determining their total supply quantities, and that if the premium payment was lifted for maize and wheat, there would be no difference in the amounts supplied. It implies that the premium payment is not sufficient in stimulating production. As Erdal and Erdal (2008) put forward, the premium payments do not encourage AEs to allocate more land to the cultivation of sunflower and soy bean but only provide protection against unfavourable market prices. Unlike maize, the total amount of cultivated areas for cotton has not been influenced by the premium payment because of its insufficient amount (Erdal \& Erdal, 2008).

As it is, the government does not opt for the augmentation of the premium payments. The import of certain agricultural crops (e.g. grains, pulses, cotton, etc.) are allowed without custom tariffs. That is, the agro-industrial company that imports agricultural crops without paying tariffs must process in Turkey and export. This step of trade liberalisation was long underpinned by overvalued exchange rates set by market dynamics by 2018. This policy clearly favoured first the domestic agro-processors that seek to acquire agricultural raw materials at international prices, and later AEs abroad rather than those in Turkey.

The SAR is ranked first in the country for cotton production, important for the Turkish textile industry as it is one of the primary sectors providing employment and foreign exchange, with the country being almost self sufficient in cotton production. One, therefore, would expect that AEs are financial viable; however, they would operate at a loss without the input subsidies and the so-called "premium" payments (Ș. G. Yılmaz \& Gül, 2015). ${ }^{106}$ F8b (personal communication, July 26, 2015) says 'he is working on cotton only for agricultural support' as a smallholder, and what he indicates is that the profit derived cotton production is formed by premium payments, and that there is no possibility for sustaining cotton production without any support payments. What F15 (personal communication, August 26, 2015) says is that he would prefer to grow a crop type with lower total cost rather than cotton, if the premium payment was abolished. When it comes to grain and pulse production under rain-fed farming, a farmer in the F5 focus group (personal communication, July 24, 2015)

\footnotetext{
${ }^{106}$ According to Yilmaz and Gul's study (2015), AEs with land between 16-30 decares are in loss although all is subsidized, while AEs with land between 61 and 100 decares make no profit or loss despite all subsidies, AEs with land above 100 decares generate profit by 5 per cent. This study clearly proves the importance of subsidies in cotton production.
} 
said that he would switch to wheat production. In other words, the cultivation of food crops would be preferred to cash crops in the absence of the premium payment. However, it does not mean that cotton producers would shift to more profitable or less heavily taxed crops as Bates (2005) suggested for his African cases; rather, they would just regress to less addedvalue food crops.

Given that the price level of any crop is determined by market dynamics, O21 (personal communication, August 27, 2015), an official working in the irrigated Harran Plain, asserted that if the deficiency or premium payment for cotton had been phased out, machinery and equipment specific to cotton production would stand idle. That would mean that their efforts would be wasted without recouping investment costs. It also implies that switching from one crop to another and preparing AEs for market conditions in this way is not straightforward for most SAEs.

\section{Non-Market Institutions to Solve Information and Measurement Costs for Agro- Processors}

We can draw a conclusion at this point: support payments in the neoliberal period are used to keep AEs in agriculture to maintain the high competitiveness of agro-industries. The case of the ICSSS subsidy proves this. As R7 (personal communication, July 24, 2015) stated, one of the reasons for subsidising improved certified seeds is to help the agro-industry to distinguish durum wheat, used for pasta production, from bread wheat, thus increasing the quality of processed food. ICSSSs are indeed important for the agro-industries to increase their competitiveness in international markets by improving the quality of raw materials, and for farmers to sustain agricultural activities in line with market demand conditions (N6, personal communication, May 8, 2015). O26 (personal communication, September 26, 2014) elaborates:

[...] the consciousness of producers, this is very important factor. [...] Especially after 2001 and 2002, they have obtained different types of supports. [...] Apart from this, they are endeavouring to produce quality products. [...] they are looking at the market [to find out] what kind of products and what variety of them industrialists want to buy, and which product has a more price level. [...] They are looking at which variety of products is resistant to cold and diseases. [...] I am not telling this for only wheat [producers]. [...] In the past, everything was subject to the Board. [...] [They were thinking that] the Board would buy [their products] in the end. [...] In the past, the industry was not developed to the current degree. My hometown is Mardin. There were four or five enterprises 
producing flour and pasta 10 or 15 years ago but 80 or 90 ones now. Our purchases have not decreased because of our policy change but the development of the industry, the awareness of producers, the emergence of new varieties and increases in supports.

The feedback mechanism to convey to AEs requests for crop quality of the agro-industry is generally based on informal, indirect processes through merchants. Other actors in the system can somewhat relay market information and signals to AEs. The extension and information system between research bodies, public extension staff, private extension firms, and farmers are suffering from the weaknesses of a top-down system (Ozcatalbas et al., 2011). The infrastructure of information and communication technology is weak in rural areas (the OECD, 2016b, p. 102). Television channels operated by private and public initiatives, and the staff members of the GAP-Agricultural Education and Extension Project (GAP-TEYAP), are more concerned with the dissemination of cultivation methods and institutional changes than they are with disseminating market-based information. With the effects of globalisation in agriculture, failure to receive and correctly interpret signals about fluctuating market prices and return rates is still confounding AEs not only in the SAR but across the country (Keyder $\&$ Yenal, 2014, p. 52). The withdrawal of the state from purchases has somewhat exacerbated the case. O26 (personal communication, September 26, 2014), an official in the Turkish Grain Board highlights this issue: 'In the past, everything was subject to the Board. [...] [They were thinking that] the Board would buy [their products] in the end.' AEs were, thus, rarely interested in changes in market conditions. In the neoliberal period they are supposed to follow changes in markets. Finding an efficient way of obtaining information, and its costs, remain a challenge for AEs, which the government has not effectively handled.

The agro-processors have solved the problem of information costs and measurement costs in the market, with the help of non-market institutions, and they can thus gather a substantial amount of raw materials to assure low costs per unit. The owners of agro-industries, mostly large landholding families, allocate their crop production for agro-food production first. In the next step, they obtain the required crop-based raw materials from other large landholders, purveying crops in high volume and of similar standards (O26, personal communication, September 26, 2014). Finally, they bargain with merchants over the price of crops that will make up the remainder, which are normally collected from SAEs. Here, smallholders can find out what varieties of a crop are preferred by agro-industries via merchants, on whom they are already highly dependent in commercial and financial terms. As for non-market institutions, through the inward processing relief help, agro-industries acquire a large amount of high- 
quality raw materials (providing that their products are exported). Again, the Turkish Grain Board and the commodity exchanges that modernised their facilities, labs and equipment, can scientifically price any crop type in terms of nutrient and quality values. In this way, they classify raw materials according to the needs of agro-processers, inform AEs of what standards the agro-processors demand, and create price dispersions to award AEs for keeping their crop at higher quality. The ICSSS subsidy has also driven AEs to use improved, certified seeds to get higher prices and adapt to market demands for raw materials. AEs however tend to cut their production costs, decreasing the use of modernised inputs because of lack of subsidies.

Bates (1989/2005, pp. 73-84) examines the origins of institutions in Beyond the Miracle of the Market taking Kenya as a case, and details that information costs and the problem of quality were not be dealt with through market dynamics but through non-market institutions. Bates (1989/2005, p. 77) argues that 'given the high costs of monitoring the quality of products, control over farm inputs thus replaces the evaluation of outputs, and rules and regulations replace markets in efforts to enforce quality standards', where price dispersion did not work well in rewarding AEs producing high-quality products.

In Turkey, as shown, the non-market institutions have not replaced markets but helped market actors to sustain or improve the quality of products. As displayed, the use of standardised inputs are secured through non-market institutions. The ICSSS subsidy and the soil analysis subsidy are driving AEs to yield crops with certain nutrition values. The Act of Seed Growing is obstructing the use of uncertified seeds by farmers. The state-funded research bodies also work or help for the use of productive farm inputs but do not impose any control over them. The Board employs price dispersion to award AEs producing high quality products. The inward processing relief offers high quality raw material to agro-processors at international competitive prices.

\section{Struggle over Agricultural Commodity Markets}

The expansion of agro-food industries has presented significant opportunities to AEs, merchants and industrialists, and therefore the withdrawal of subsidised purchases has not resulted in excessive political pressure on the government. In fact, the pressure from rural families has also eased with increased urbanisation and non-farm jobs (supplementing rural incomes). The former indicates a marked decline in the electoral power of the rural whereas the latter refers to complicated or fragmented interests. 
Before the 2000s, coalition governments experiencing harsh political competition, at times endeavoured to favour AEs with higher prices and agro-processors with lower prices. As we shall demonstrate, an Olson-like argument is today valid in agricultural commodity markets under the neoliberal regime. A small groups of merchants and agro-industrialists act collectively to reap benefits but most AEs cannot. Although farmers are complaining about this fact, they cannot lobby the government because they lack collective action (and because of the factors mentioned above). This contradicts what Bates (1989/2005, pp. 85-89) explains about the Kenyan industrial struggles. That is, the political mutual relationship between politicians and rural and urban dwellers resulted in Kenyan agro-processors being squeezed between them. They were 'large-scale, vocal and active lobbyists' but not effective ones 'for want of an ability to take refuge in economic alternatives, thus not resisting predation' (Bates, 1989/2005, pp. 86, 89).

In the neoliberal period after 2001, as explained before, the dominant coalition is formed by the bureaucratic class, different factions of the bourgeoisie, and the ruling government, representing the interests of the latter but having obtained support of the conservative periphery to come to power. In this political setting, whilst agricultural producers are exploited by merchants and agro-processors, the government, as mentioned in the background chapter, mobilises non-market actors (e.g. local officials and religious networks] and provides assistance via informal mechanisms to alleviate political repercussions. As a result, agricultural producers, lacking collective action to lobby the government to change policies, fall victim to predation in the market as well as being exploited by merchants and agro-processors.

An expert at the Chamber of Agriculture in Adiyaman, N5 (personal communication, September 19, 2014) claimed that merchants and brokers acted like a cartel to control price levels in the market. O26 (personal communication, September 26, 2014) confirmed that claim, stating that industrialists make a deal with buyers on a certain price beforehand, and then also make a deal with the merchants based on that price. Finally, the merchants join together to control prices in the local market, which somewhat reduces profits for SAEs. As mentioned before, the Board generally intervenes in grain markets where prices are kept at a low level by merchants or wait until SAEs repay their debt to merchants by selling outputs at lower prices. A lack of intervention-oriented to the interests of AEs leads to SAEs making a loss and possibly withdrawing from agriculture, thereby resulting in reduced grain production, impacting on urban populations. When a supply deficit emerges in the grain 
market, interventions made by the Board or the import of grains, which are facilitated by the relatively more liberalised trade regime, depresses increasing prices in favour of urban consumers and industrialists, at the expense of farmers (M. Öztürk, 2012, pp. 94-95). The former groups can obviously put more political pressure on the government than the AEs. ${ }^{107}$

Apart from local merchants depressing prices through setting up a cartel, merchants from other regions also visit the SAR to purchase agricultural commodities on the cheap. F7a (personal communication, July 24, 2015) highlights this fact:

[...] When [a crop] season in Adana ends, and when the crops are released, for example its price is 1100 Turkish liras. When the crops cultivated here are released, its price is decreased by 200 or 300 Turkish liras by Cukobirlik. ${ }^{108}$ This is true for cotton and other crops. [...]They say, "After all, everything got abundant", and they start dropping prices. There is ever no price stability.

If merchants from other regions can buy enough crops in their own region, they do not feel a pressing need to purchase crops cultivated in the SAR. In such a case, buying crops from the $\mathrm{SAR}$ is regarded as an extra business to gain extra profit. They therefore have a high bargaining power and offer lower prices to producers in the region (Borlu, 2015). This phenomenon sharply distinguishes the SAR from the other regions. Lack of capital leads to lack of agro-industries, insufficient total market depth to absorb agricultural production and to the further exploitation of agricultural producers in the SAR by merchants and agroindustries from Turkey's western regions.

Another decisive factor behind the exploitative dependency of AEs in the SAR on merchants and agro-processors is that the marketing network is marked by the lack of competition between market actors in purchasing agricultural crops, although the regional agro-industrial capacity has expanded in recent years. Statistics confirm that there is still an imbalance between the regional agricultural production and industrial production. The share of the regional industrial production to Turkey's total industrial production is around 5.10 per cent, whereas the share of regional agricultural production to Turkey's total agricultural production is around 10.38 per cent (Turkish Statistical Institute, 2018a). F17, who lives in Adiyaman,

\footnotetext{
${ }^{107}$ Every Turkish citizen over 30 years old was taught in primary school that: "Turkey is one of seven countries that can totally feed itself." Whenever agricultural commodity prices increase in Turkey, urban people blame the government, and the government relaxes trade barriers to allow the Board to import grains. However, protests made by farmers about low agricultural prices, are often ignored by politicians and the media. See also Keyder and Yenal (2014, pp. 14-15)

${ }^{108}$ The Cukobirlik cooperatives actively work in several cities. The mentioned cooperatives come to the SAR from other regions to buy crops as merchants but not as actors of a cooperative.
} 
which has fewer industrial firms than Gaziantep, Sanliurfa and Diyarbakir, draws attention, albeit exaggeratedly, to a different aspect of this imbalance:

F17: Farmers have nothing to sell to [the firms located in] the organised industry zone.

There is an edible oil production facility but there is no cotton and maize [grown in Adiyaman]. They come from outside [the region] for textiles. If there is not any [irrigation] water, you cannot produce them.

The guest: In that textile [industry], [fabric] pieces are brought from large facilities [...]. They are brought from Istanbul and assembled [by sewing] here [...].

F17: [...] How cheap labour force is in China [...]. Here, Adiyaman is Turkey's China.

In fact, field crop producers are complaining less than vegetable and fruit producers in selling their crops to agro-industries but mostly feeling disgruntled because of the low prices they receive. Among field crop producers, both tobacco and cotton producers are complaining about the lack of industrial capacity to absorb their production. For example, a farmer in Harran, Sanliurfa, F34 (personal communication, August 27, 2015) with 360 decares of irrigated land, compared cotton producers in west Turkey to those in the SAR, with the latter receiving lower prices due to lack of capacity in the SAR textile industry. N9 (personal communication, May 11, 2015) explained that cotton was produced in the SAR but fabric was produced elsewhere. She commented that fabric was brought back to the SAR to produce textile products and clothes.

Fruits and vegetable producers in the SAEs are also complaining about the lack of industries to purchase their products. The pomegranate is a case in point. F17 (personal communication, September 6, 2014), a smallholder in Adiyaman, described how difficult it is to sell pomegranate, talking about a case with an industrial firm which attempted to buy pomegranate for juice production:

Interviewer: Is contract farming widespread?

F17: [...] that man says, "How is the average price of pomegranate in the market? Its [ton] is 700 liras. I would buy it for 500 liras. If you like, give it to me, otherwise do not. He does not buy at the normal price [level].

Interviewer: There is no long term contract, I mean, for 5 or 10 years.

F17: No. [...] The Hejaz type of pomegranate is appropriate for Adiyaman's climate. It is for factories, I mean, can be processed in factories. It can be made into pomegranate treacle and juice. Then, it can be consumed edible. Keeping this [type of pomegranate] in 
a cold storage lasts longer. [...] But everyone is attempting to uproot them because there is no market $[\ldots]$.

Interviewer: There is no guidance of the government?

F17: No, there is not. I mean, [...] the government tells "you must plant it in the first year, but you cannot pull it in five years." [...] I spent 4000 liras for pesticide, 3000 liras for electricity and 2000 liras for diesel. Then, I sold pomegranate but realised that it did not cover my cost. [...] if you have 50 bovines, there is the milk support, 15 kurus [per liter], when you sold it. If the support existed as 15 kurus per kilogram, farmers would go on [pomegranate production] at least. [...] yet, my tree[s] are seven years old. If I cut them, I will be disappointed. [...]If it covered my cost, it would be enough for me. [...][Unfortunately,] I will do dry-land farming instead. [...] For example, farmers are planting almond [trees] but its market [conditions] will be the same. To whom you will sell almond. [...] everyone will plant it and then it will cause trouble because no export is done. If export was possible, and the provincial agricultural directorate brought buyers from abroad, [maybe] [...].

Pomegranate cultivation was financially encouraged under ARIP to divert farmers from tobacco production, but resulted in commercial failure. One can argue that such support interfered with the decision making process of AEs. Several years ago farmers decided under market rules to plant almond receiving a relatively higher price, which can be stored longer than pomegranate. However, most of them are unable to profitably sell it. ${ }^{109}$

In conclusion, SAEs and MAEs have the most disadvantage position in agricultural commodity markets, a market which favours merchants, brokers, exporters, supermarkets and agro-processors (which compose the bourgeoisie). What $\mathrm{O} 17$ said (personal communication, May 5, 2015), an official in the Mardin agricultural directorate, is self-explanatory:

O17: Believe me, farmers cannot earn anything now but could they if organised.

The interviewer: $[\ldots]$ why do the state not alter the system depending on brokers and merchants?

O17: [...] Now, [one of] the biggest sectors in Turkey is the food sector. [...] Everybody now talks about the arms sector, but the biggest problem in the world is the food sector. Few companies keep [the sectors of] food and seed in their hands, and they have started

\footnotetext{
${ }^{109}$ Smallholders in the focus group of F18 (personal communication, August 26, 2015), located in Sanliurfa, stated that they had a different variety of pomegranate to enable them produce it earlier than Hejaz producers, thus receiving a higher price. Despite all this, they cannot find sufficient number of buyers to sell their products. They also added that this problem is prevalent in fruits and vegetable farming in general.
} 
to control the world [through this power]. It is, now, not seen in Turkey that the wealthiest people are dealing in food. How would they be disintermediated? Turkey has not been able to transition to a system of corporations like the United States of America; yet, merchants and building contractors are governing Turkey. They might be disintermediated one day in the future. No one shoots their rich people in their feet; the system is now working in this way.

\subsection{The Privatisation of the TEKEL Company and the Tobacco Market}

One of the neoliberal policies that have affected the SAR was the withdrawal of the state from the market of tobacco and tobacco products. The main reason of such a policy was that the unsold tobacco in the TEKEL's inventories was leading to a loss and in turn laying a substantial burden on the public budget during the 1990s. It was mainly made up of tobacco from the east regions, as it was less demanded by tobacco companies compared with the tobacco produced in the western regions because of its poorer quality (Kayaalp, 2009, p. 140; Yürekli et al., 2010, p. 16).

Prior to the ARIP, a quota for tobacco production was re-introduced in 1999. When the 2001 economic crisis severely hit Turkey, 30,000 poor tobacco producers, including SAEs and sharecroppers, were abruptly forced to give up agriculture in Adiyaman (Kaya, 2015; Kayaalp, 2009, p. 165), where the tobacco production of the SAR is traditionally concentrated. The ongoing process was finalised with the privatisation of the TEKEL. The outcome was a fall of about 55\% in Adiyaman's tobacco production between 2000 and 2005 and of a further $9.5 \%$ between 2005 and 2015. As for the entire SAR, decline rates in tobacco production were even more dramatic in the mentioned two periods, respectively $51 \%$ and 46\% (Turkish Statistical Institute, 2017a). Adiyaman's vegetative production, adjusted at 2009 prices, annually contracted by $9.17 \%$ between 1999 and 2001. In the ARIP period, it dropped again by 3.08\% annually between 2001 and 2008. The contraction in tobacco played an important part in the decline of vegetative production (Turkish Statistical Institute, 2018a). While the cultivated areas of tobacco in Adiyaman plunged from around 15365 to around 7530 ha between 1995 and 2015, the anticipated shift from tobacco to alternative crops within the ARIP did not materialise (Karabacak, 2017). Adiyaman's vegetative production has later grown by $4.51 \%$ averagely in the period of 2008-2017; with its value in 2017 nearly recovered to its 1999 value (Turkish Statistical Institute, 2018a). Interviewees complained during the fieldwork that pomegranate, almond and walnut are being grown as alternative crops to tobacco, but they have not yielded the same result because of marketing problems. It 
is therefore reasonably to infer that the removal of subsidised purchases of tobacco have adversely affected Adiyaman's agriculture and the wealth level of agricultural producers. O16 (personal communication, September 22, 2014), an experienced official in Adiyaman, explains how such sharecroppers have been sifted out since 1999:

[...] we had 40,000 [actual] owners of registration cards. [...] I mean, 40,000 are multiplied by 5; it was a matter of interest for 200,000 people at least. In Adiyaman, tobacco was equally as important as grain. Those people became like a fish out of water when the state stopped buying tobacco. Those 200,000 people were all not in the same situation. 20,000 or 30,000 of them had [already] owned a land. The rest, 170,000 or 180,000 of them, had been working [...] as sharecroppers. [...] tobacco production is a labour-intensive one [...]. [...] the state suddenly quitted this. Around 200,000 people, in a small-scale city like Adiyaman, were out of employment. What does it mean? I do not want to list the words like the burglar, the prostitute, the racketeer, the snatcher and the drug seller. I mean, we started to think of such words rapidly. [...][the state] never figured out, "I am applying such a project but how will I evaluate the potentiality resulted from this?"

\subsubsection{The Tobacco Law}

In 2002, the tobacco law, legalised in line with Turkey's commitment to the IMF, enabled the free market mechanism in the tobacco sector through contract farming. This worked as "a market device" that would eliminate politics and distorting state interventions (e.g. the subsidised purchases of tobacco) from the economic domain (Kayaalp, 2009, pp. 151-153). As mentioned earlier, the government commenced to gradually abandon the DIS independent from production between 2005 and 2009 - and instead expanded productionrequired subsidies without renouncing the market-oriented perspective. As a traditional export crop, tobacco would never be subsidised again. Based on the tobacco law, the subsidised purchase of tobacco was completely abolished in 2008 through the privatisation of the TEKEL, and from then multinational tobacco companies have totally dominated the Turkish tobacco market (Yürekli et al., 2010, p. 16). After market dynamics became totally dominant, tobacco sales from east Turkey to private companies have contracted and come to bring producers lower prices than have those from west Turkey (The Tobacco and Alcohol Markets Regulatory Authority, 2016). ${ }^{110}$

\footnotetext{
110 Varying prices between regions is another issue leading to dissatisfaction and the feeling of being discriminated. Farmers in the SAR fervently believe that their own tobacco is the best in Turkey and even in the world. According to state-based data (The Tobacco and Alcohol Markets Regulatory Authority, 2016), the
} 
The termination of state interventions in the tobacco sector, with the enactment of the Tobacco Law, evoked three different responses from tobacco producers. One group started to engage in contract farming, as directed by the Tobacco Law. Another group preferred to illicitly sell loose tobacco in the unregulated market. A final group commenced to grow alternative crops, which the government subsidised for several years under the ARIP to alleviate the economic problems that would arise from the liberalisation of the tobacco market. Note that we will address this last group when discussing well-designed and illdesigned government interventions.

\subsubsection{Contract Farming in Tobacco and Illicit Tobacco Sales}

The tobacco law altered the marketing system in tobacco, introduced contract farming ${ }^{111}$ and then proceeded with the application of quotas to obviate any oversupplied, unsold tobacco in the inventories of the TEKEL. After the privatisation of the TEKEL in 2008, the quota policy was necessarily abolished, and the method of contract farming totally dominated the market regulated and monitored by The Tobacco and Alcohol Market Regulatory Authority (TAPDK in Turkish acronym). In the meantime, the demand for oriental tobacco in the regulated market slumped for several reasons: a determined effort for tobacco control made by the government in line with the global framework stipulated by the World Health Organisation; increases in taxes relevant to tobacco control, which in turn expanded the illicit loose tobacco market; new developments in cigarette production regarding input types, and the adaptation of cigarette blends in response to changes in customer tastes and preferences (Yürekli et al., 2010).

In addition to the dramatic drop in the demand of oriental tobacco in the regulated market, tobacco growers have not enjoyed the practice of contract farming itself so far (Gumus, 2008). Kayaalp (2009, pp. 154-155) explains the case:

Farmers stuck with their contracted buyers do not have any choice but to sell their crops to them. The tobacco market being structured under contracts strictly binds sellers to buyers. The underlying logic of contract farming is to initiate a competitive market setting, but instead it has brought about a more strictly designed and controlled structure preventing all kinds of competition. Furthermore, it is not a secret that tobacco leaf companies negotiate with each other about the price they will offer to farmers.

regional disparity between west Turkey and east Turkey is 54 per cent with regard to oriental tobacco prices. Tobacco prices offered to farmers in west Turkey was 14.18 liras but only 9.17 liras for those in the SAR.

${ }^{111}$ In contract farming, an agricultural enterprise and a buyer (the leaf company in this context) make an agreement prior to crop production, in which they agree on the price level, farming methods, production standards, assistance or extension, etc. (Kayaalp, 2009, pp. 74-75). 
Afterwards, (Kayaalp, 2009, pp. 155-156) compares the old tobacco market with the new one:

In the old tobacco market, on the other hand, tobacco farmers used to have the flexibility of choosing their buyers. [...] After grading tobacco, TEKEL used to announce the maximum price offered for the best quality crop. Farmers, having different grades for their crops from different merchants, were then able to calculate how much they would earn. They had the option of choosing their buyers, usually the highest grader, and then conclude their agreements. This tobacco market offered a more competitive setting with its diverse choice of sellers and thus prices. [...] It is correct that the monopoly's purchase of all grown tobacco gradually raised the supply side and created a big hole in the budget. But it is very hard to claim that the monopoly's price intervention was really an obstacle to the development of a competitive market. On the contrary, the old market was relatively more competitive and "free" compared to the contract system [...]. [...] From the perspective of the international financial institutions, as well as national proponents of neoliberal policies, free market simply implies the non-intervention of the state [but not the formation of a competitive market].

In other words, the aim is clearly to create a market operating in favour of first multinational or international and then national large-scale capitalist classes in the case of tobacco.

Interestingly, the new "competitive" marketing system has created illegal tobacco sales between producers and the tobacco leaf companies or the brokers who sell the tobacco collected to multinational tobacco manufacturers. Those manufacturers are not bound by any formal contract, thus buying tobacco from tobacco leaf companies at varying quantities every year. When the demand for tobacco decreases, tobacco leaf companies transfer this decrease to tobacco purchases from farmers at that year, exploiting the flexible nature of contracts; for example, they refer to the required quality standards to not buy a specific amount of tobacco (Kayaalp, 2009, pp. 186-188). When there is unsold tobacco in their possession, tobacco producers are supposed to sell them in auctions arranged by the TAPDK. As auctions would lead to the loss of time and of quality in tobacco because of bureaucratic red tape, unsold tobacco is often sold 'under the table' to tobacco companies via brokers at lower prices (Kayaalp, 2009, pp. 74-75, 185). Where the lack of well-functioning tobacco cooperatives prevails, tobacco growers are unable to enhance their bargaining power against those actors and receive a higher price. Apparently, the termination of the monopoly through privatisation has resulted in the welfare transfer from tobacco producers to multinational cigarette manufacturers, tobacco leaf companies and brokers. 
Moreover, given that tobacco manufacturers, tobacco leaf firms, private and public research bodies specialising in tobacco, and the Union of Aegean Tobacco Exporters have agglomerated in the western regions, it is clear that the current system is working against farmers in the East. ${ }^{112}$ F23 (personal communication, September 8, 2014), a focus group including several members of the Association of Adiyaman Tobacco Growers ${ }^{113}$, involved in selling tobacco illicitly, clarifies this further:

F23a: Private companies give only their tobacco [seeds to farmers] for their cultivation.

Interviewer: It means that they do not furnish them with advisory and extension service or knowledge.

F23a: No. They just gather tobacco leaves.

F23b: With a low price.

F23a: With a miniscule price. I mean, [they imply to the folks] "do not be idle, and work". I mean, we [illicitly] sell this by 20-30 liras per kilogram, [but] private firms purchase it by 5 or 6 liras.

F23b: If a man plants [tobacco] on a 2 decares of land, and grow it for 5 or 6 liras per kilogram, he would make 200 or 300 liras per year. [In this way,] would he sustain his kids' education or live on? ${ }^{114}$

F23a: If they bought my product for 20 or 30 liras, why would I sell it illicitly? [...]

Interviewer: [...] You, [the farmers in] the Aegean [region] and Adiyaman, have the same [market] conditions. I would like to turn to local conditions. They established an exporter union, but you don't have it here.

F23a: We do not have a financial power. [...]No matter which state organisations we have visited, their doors are closed to us. After that, our farmers are afraid. They avoid being organised. For example, if the government decides that this is free in a legal

\footnotetext{
112 The system is working in favour of tobacco growers in East Turkey. According to Gumus (2008), 76 per cent of the surveyed farmers in west Turkey are not satisfied with contract farming, particularly due to the low tobacco price.

${ }^{113}$ Its name sounds highly formal; yet, this association has less than 10 members and relies on an informal network.

114 The farmers interviewed do not provide a more quantitative insight into the production and income levels coming from tobacco. According to Turkish Statistical Institute (2017a), the average production per decare was 78 kilograms in 2015 in Adiyaman, and a 2 or 4 decare of plot is generally used for producing and selling loose tobacco (Uznay \& Gümüs, 2016). A SAE with 3 decares of land would be able to make 234 kilogram of tobacco and around 179 liras per month (around 45 pound) given that the average tobacco price is 9.17 liras in 2016 under contract farming (The Tobacco and Alcohol Markets Regulatory Authority, 2016). For a smallholding family, such an income level is not sufficient to live on. Nonetheless, a kilogram of tobacco is worth 60 liras in the illicit market; therefore, the same SAE would make 1170 liras per month (around 296 pound), which is almost sufficient to sustain life.
} 
manner, $[\ldots]$, the sense of misgiving among farmers will end. [...] We would double [what] the Union of Exporter in the Aegean [region has done].

Interviewer: What is their advantage?

F23a: They can come here and freely have tobacco planted. They distribute seeds. [...] The Union of Aegean [Tobacco] Exporters buy it [from farmers] for 7 liras and then sell it for 40 liras. [However,] when I buy it for 20 liras, I can sell it 30 liras [...]. [...] There is nothing in farmers' hand. Wheat and barley always make a loss. There is no water to plant maize and cotton here. There is no alternative for farmers. There is no way except tobacco. Otherwise, they would be glue-sniffers or thinner-sniffers.

A group of farmers, who overwhelmingly own SAEs, bootleg loose tobacco in the unregulated market, under the unofficial brand of Celikhan, a town in Adiyaman famous for its own distinctive tobacco. The farmers do not have any direct relationship with the tobacco leaf companies. Uznay and Gümüş (2016) argue that the establishment of tobacco cooperatives, technically and financially assisted by the government, is required to help them legally operate in the regulated market. However, amendments in the tobacco-related legal framework, the provision of technical machinery and information and the improvement of the marketing channels must take place. ${ }^{115}$ Kayaalp (2009, p. 196) asserts that farmer groups in Celikhan intended to establish a cooperative, engaging in production and sale without any assistance from the government; yet they realised that this highly costly investment would fail because of the high tax on tobacco products. SAEs and MAEs generally pay low tax rates deducted at source, varying between 2 and 4 per cent, when selling their crops to market actors (Hayran, 2013). However, if those farmers groups in Celikhan had initiated the production of tobacco products such as cigarettes, they would today pay the tax rate of $83.4 \%$ for a box of cigarette (Çakmaklı, Demiralp, Yeşiltaş, \& Yıılıırım, 2018).

Tobacco producers operating in the unregulated market are often unemployed and marginalised (Kayaalp, 2009), and their small plots do not allow them to sustain their lives without tobacco production (Karakaş, 2014). Loose tobacco production takes place in towns, in which people have so far been susceptible to the armed conflict between the Turkish state

\footnotetext{
${ }^{115}$ Uznay and Gümüş (2016) establish that tobacco farmers in Celikhan are okay with paying taxes and receive a lower price in return of being accepted in the legal tobacco market, and then put forward a detailed plan for the loose tobacco market. According to this plan, a protected geographical indication for Celikhan tobacco should be obtained from the Turkish Patent Institute. A special tax and incentives on loose tobacco, providing an advantage to its producers and consumers, should be introduced in line with the EU legal framework. The tobacco cooperative and facilities for processing tobacco should be set up and supported financially by the government. Finally, the legally determined production capacity for such a facility should be decreased 15 tonnes to 1 ton; the strict condition on installing new technology-based machinery should be changed.
} 
and the PKK, such as Celikhan town of Adiyaman, Gurs District of Mardin, and Lice and Kulp towns of Diyarbakir (Uznay \& Gümüş, 2016). For example, the ongoing bans on pasture use has inflicted a blow on livestock production in those towns, and in turn hit their income resources. As F4 (personal communication, July 14, 2015) asserted, when agricultural subsidies on tobacco were terminated, tobacco producers in Lice, Diyarbakir directed their attention to the long-existing illegal cultivation of cannabis. This case proves that the lack of government intervention to foster alternative farm and non-farm income resources has created the unregulated illicit market in tobacco.

\subsubsection{The Political Conflict on Tobacco}

Despite the political tussle, both regulated and unregulated tobacco markets have been maintained for more than a decade. This phenomenon evidently contradicts with both Olson's and Bates' arguments.

According to Olson (2002, p. 33), 'small groups can provide themselves with collective goods without relying on coercion or any positive inducements apart from the collective good itself'. He explains the reason:

This is because in some small groups each of the members, or at least one of them, will find that his personal gain from having the collective good exceeds the total cost of providing some amount of that collective good; there are members who would be better off if the collective good were provided, even if they had to pay the entire cost of providing it themselves, than they would be if it were not provided.

Olson would predict that multinational tobacco companies as a small group would succeed in having the illicit tobacco market abolished by lobbying the government, which has so far not happened in the case of Turkey's tobacco market.

Bates (1989/2005, pp. 86-89) argues that politicians in the single-party system could prevent large-scale processors by skilfully handling the legal framework and public authorities from imposing higher prices for their products and paying lower prices for raw materials, where urban consumers and small farmers constitute the vast portion of electoral power. Consequently, the interests of local politicians interact with the interests of those who can operate effectively on the national political domain. And large-scale processor could find themselves squeezed between all the mentioned groups.

Olson and Bates consider such cases as a zero-sum game. Large groups (e.g. too many smallholders) suffer from predation in Olson's argument but so do small groups (e.g. large 
processors) in Bates's argument. But in the case of Turkey's tobacco market, each group has received benefits.

Governments are political machines as much as they are economic ones. The Tobacco Law had been delayed for many years by various governments shying away from losing the votes of tobacco producers. The 2001 economic crisis forced them to take a step forward, as the economic assistance given by the IMF and the WB were contingent upon the enactment of various laws, including the Tobacco Law (Kayaalp, 2009, pp. 66-67). In accordance with the law, the government privatised the TEKEL, changed the tobacco marketing system, eliminated the state purchases in tobacco and let global tobacco companies dominate the tobacco market. Implementing neoliberal policies as required, they succeeded in obtaining financial assistance from international organisations and in convincing international creditors of the fact that they are on track. They overcame the economic crisis, boosted the economy and in turn successively won many general and local elections. They also justified heavy taxes on tobacco products, referring to the commitments given to the World Health Organisation for tobacco control, thus securing more public revenues.

Big tobacco companies have obtained many benefits. The TAPDK was established as a nonmarket institution within the Tobacco Law, in line with global standards (Kayaalp, 2009, p. 67). The TAPDK having financial and administrative autonomy assumed the mandates of regulating, monitoring and enforcing the production and sales of tobacco leaves and tobacco products, licensing manufacturing, and sanctioning those who violate the law, in order to secure free market conditions without government interventions ("Law on Regulating Tobacco, Tobacco Products and Alcohol Market," 2002). It is noteworthy that the TAPDK has never allowed big tobacco companies to be represented on its board and thus they could not influence the decisions of the board this way (Kayaalp, 2013). No matter that the TAPDK has largely been under political influence and hardly fulfilled its mandate because of its technical incapability (Ozel \& Atiyas, 2011), the regulatory agency and the government have never obstructed contract farming in tobacco that assures lower prices for raw materials for big tobacco companies. Furthermore, the agency also stifled any attempt to produce cigarettes by small producers by putting high-level barriers based on legal and technical conditions ${ }^{116}$ (O. Doğan, 2012, p. 84), thus letting big tobacco companies spike their market concentration.

\footnotetext{
116 Those who intend to establish a factory are bound to set it up with the minimum capacity of 2 million cigarettes a year and to install machines with up-to-date technology.
} 
Although the government has frequently raised taxes on tobacco products, big tobacco companies have succeeded in increasing their sales and profits through innovative products, strong marketing and pricing strategies, cost-saving strategies, and the ineffective tobacco control implementations of the government (Keklik \& Gultekin-Karakas, 2018). Given that the state monopoly withdrew from the tobacco market in 2008 , the tobacco companies have enjoyed the market share left by the monopoly. They also benefit from state subsidies given for production, export and import of tobacco products without any obstruction (Keklik \& Gultekin-Karakas, 2018).

The main complaint the tobacco companies made about the tobacco sector is the illicit sales of loose tobacco, which are produced by tobacco farmers in the SAR, especially in Adiyaman. It is illegal because they do not have a licence that must be obtained from the TAPDK for the sales of tobacco. This licence requires paying taxes and making certain investments, which render the business unprofitable for the farmers.

Selling their products without any licence, tobacco producers occasionally had problems with security officials but can run their business one way or the other. F23a (personal communication, September 8, 2014), the head of the Association of Adiyaman Tobacco Growers, explains:

Interviewer: $[\ldots]$ there is a problem with being organised?

F23a: Yes, there is. [...] I set up this association, and I am the head of it. A man readily thinks if pressure was put on the association, what would happen. He is afraid of coming to the association [because] he experienced a trouble in the past. [...] He thinks that if the state terminated the association, all of us would be prisoned. But [the state] is somewhat winking at [this illicit tobacco sale]. If they allowed this by legislation, I would feel more relaxed. Then, I would even send it to the Europe and the Middle East.

Although the constituency of Adiyaman have mostly voted for the ruling party, the representatives find it difficult to lobby at the top-level of the state mechanism in favour of tobacco producers, a complaint that they were frequently making during the fieldwork. However, it is clear that the government has mostly overlooked their businesses, and the gendarmerie often have done the same, as I learnt from the tobacco producers. The ruling party has assured their votes from tobacco producers this way. Apart from this, Adiyaman is a Kurdish densely populated province, which has given a little support to the cause of the Kurdish political movement. It seems that, to increase their bargaining power, the local notables and the tobacco producers generally use a discourse referring to their ever-present 
support to the state against the PKK ("The Adiyaman Tobacco Would Not Belong to the PKK," June 29, 2017). I think that the state and government officials do not push these people to the arms of the Kurdish political movement, so implicitly permitting the illicit tobacco sales. Consequently, the TAPDK without any security power have remained ineffective in its sanctioning.

The interviewer: The state says, 'produce tobacco how ever you want to produce, but if you sell it in this way, I cannot allow you. Am I right?

F23a: Yes

The interviewer: But there is a tobacco market in Urfa and Diyarbakir. Are they intervening in them [to avoid tobacco sales]?

F23a: No. They are not intervening in the market. They are not intervening in tobacco in your hand, but if the gendarmerie catch us on the road [to sell it out of Adiyaman], then they intervene in it.

Many tobacco producers in the SAR benefit from the tobacco sales. It is estimated that the illicit tobacco market is equivalent to $14 \%$ of the legal one in Turkey (Uznay \& Gümüş, 2016). One way or the other, the big companies, and tobacco producers and illegal sellers take benefits from the tobacco market without being into complete predation.

\subsection{Successful and Unsuccessful Cases of Government Interventions}

Our analysis has so far focussed on the issue that the government interventions within the neoliberal agricultural regime that are made because of inherent characteristics of agriculture itself, have created positive results in the SAR, but their insufficient level has limited its success. In some cases, the withdrawal of government interventions have badly affected AEs, especially smallholders. In this section, we will focus on project and programmes that have been implemented by the government in the SAR's agriculture.

One who read Markets and States in Africa would see a lot of examples of failed projects and programmes, indicating that government interventions are generally harmful to economic development (Bates, 2005, pp. 45-61). In Essays on the Political Economy of Rural Africa, (Bates, 1983, p. 119) contends,

An important objective of African governments is to increase food supplies. To secure greater supplies, they could offer higher prices for food or invest the same amount of resources in food-production projects. There is every reason to believe that the former is 
a more efficient way of securing the objective. But governments in Africa systematically prefer project-based policies to price-based policies.

In this section, drawing upon cases from the SAR, we argue that how well projects and programmes are designed is a key factor in how much government interventions become successful. The somewhat normative term 'well' refers here to the government devising projects and programmes with the help of stakeholders in the agricultural system, contributing to efforts put for agricultural development in the SAR. In fact, we have never ignored the importance of higher prices for agricultural production, but have showed that the agricultural surplus produced are appropriated by commercial and industrial capitalists, thereby encouraging AEs to leave agricultural activities. In this circumstance, well-designed projects and programmes have stimulated agricultural development, which in turn slowed the exodus of farmers from agriculture.

\subsubsection{Designing Government Interventions through the Poly-Centric Governance}

One of the important contributions in RCT was made by E. Ostrom (2011) in Governing the Commons, who focused her efforts to understand self-organising and self-governing common pool resources, such as grazing areas, closed fishery areas, groundwater bodies. However, the implications of her study can be extended to self-governing resource or public good systems, or even highly specialised systems which may be special districts, private associations or parts of a local government (E. Ostrom, 2005, p. 283). Government interventions in agricultural development can be deemed as a public good. In this regard, when a rural development fund is formed, our presumption is that it is to be designed, financed, distributed and enforced with the participation of public and private bodies in order to achieve success.

Ostrom addresses failed and successful cases and shows how users set up institutions to specify how to benefit from common pool resources and maintain them for securing the constant stream of the benefits, how to modify those institutions to changing conditions, and how to resolve disagreements or conflicts. She also notes that 'most of the institutional arrangements used in the success stories were rich mixtures of public and private instrumentalities' (E. Ostrom, 2011, p. 182).

From similar studies, Ostrom and her colleagues have devised and developed over a long period the polycentric governance approach 'for the analysis of collective-action problems involved in the provision of diverse public goods and services' (E. Ostrom, 2010b). One of the important aspects of public goods is that those who do not participate in paying for costs 
made cannot be excluded from their consumption because of prohibitive costs of doing so. The free-rider problem emerges in such a case, and private agencies, therefore, cannot provide such goods and services as they are unable to impose prices on each consumer (T. Cowen, n.d.).

Public goods are provided by public agencies, and the issue of how to provide them gives rise to several basic questions such as how to organise public agencies, how to govern the whole organisation, and how to solve conflicts between agencies, etc. In this context, '[p]olycentric systems are characterized by multiple governing authorities at differing scales rather than a monocentric unit' (E. Ostrom, 2010b). When the term was first coined in study of V. Ostrom, Tiebout, and Warren (1961), it addressed the assumed pathologically chaotic order of producing and providing public goods in metropolitan areas by diverse public and private agencies at different layers of governance. It proposed that polycentric governance could be more successful than a political governance with a single dominant centre for making decisions:

\begin{abstract}
"Polycentric" connotes many centers of decision-making which are formally independent of each other. Whether they actually function independently, or instead constitute an interdependent system of relations, is an empirical question in particular cases. To the extent that they take each other into account in competitive ${ }^{117}$ relationships, enter into various contractual and cooperative undertakings or have recourse to central mechanisms to resolve conflicts, the various political jurisdictions in a metropolitan area may function in a coherent manner with consistent and predictable patterns of interacting behavior. To the extent that this is so, they may be said to function as a "system."
\end{abstract}

As E. Ostrom (2010a) infers from the literature, decentralised governance systems, including the small but many providers of public goods, are far more likely to outperform large, centralised governance systems, in terms of technical efficiency and output.

One of the important aspects of the polycentric governance systems is that it requires to authorise civil or private stakeholders (e.g. the users of smaller-scale common pool resources) to define policies, set up institutions and check the system. Their participation would definitely bestow advantages for improving and sustaining the system, such as the utilisation of both local and issue-specific disaggregated knowledge, building trustworthy for promoting

\footnotetext{
${ }^{117}$ It indicates that competition between different producers and providers of public goods would help the governance system develop through self-regulating tendencies that forces them to find the more effective solution. In particular, the separation between producer and provider of the public good significantly matters to reach success (V. Ostrom et al., 1961).
} 
social capital, better adaptation to the system, lower enforcement costs, the establishment of parallel autonomous systems that lowers the possibility of any failure to afflict the entire connected milieu (E. Ostrom, 2005, pp. 281-282)

Ostrom and her colleagues have developed an institutional analysis framework that involves the most general set of variables the researcher may use to investigate various ranges of institutional settings. Doing an analysis through that institutional framework goes beyond the limits of this research. In the next section, we just shall take some cases from the SAR to show that to what extent governmental interventions in the form of projects and programmes are governed by the polycentric approach have determined the degree of achieving success.

\subsubsection{Unsuccessful Cases in the SAR of Government Interventions}

We shall take two cases here. The first one is concerned about the alternative crop production project created within the ARIP to encourage farmers to abandon tobacco production. The second one addresses the Harran irrigation union and its problems ailing its operation.

\section{An Unsuccessful Case: The Alternative Crop Production Instead of Tobacco Production}

The replacement of previously highly supported and overproduced crops (i.e. hazelnut and tobacco) with alternative crop types was one of the objectives of the ARIP. The safety net was based on a simple mechanism, that is, when the price subsidies were decoupled, producers of those crops would face a disincentive to produce these crops. To make the transition smoothly, an incentive was created. The one-time cost of the shift, such as costs of buying inputs and preparing and tending fields in the transition period, would be covered by financial assistance provided by the WB (The World Bank, 2001b, p. 14). The WB and the concerning ministry did not contact local producers for devising the plan or in order to find out their circumstances and opinions. The project had a top-down management style, governed by a single dominant centre.

Support for the alternative crop production was available between 2002 and 2007. In this period around 97 per cent of the total support for the replacement of tobacco was paid to those who had left its production in Adiyaman (Gül, Arısoy, Sivük, \& Ataseven, 2009). The total areas cultivated for tobacco declined by $35 \%$ in the implementation period of the project, and most of those who decreasingly engaged in it over years, started to cultivate grain types with far lower profit margins, such as canola, wheat and safflower (Gül et al., 2009). 
O16 (personal communication, September 22, 2014), an experienced official in the Adiyaman agricultural directorate, explained why this project failed:

[...] that [alternative crop] project succeeded but within its own scope. What is that scope? You do not remove people from lands but set them adrift. [...] Is the rest of the life of this man only one year or two years [...]? [...] The support that [the state] gave was 100 or 200 liras [per decare]. It is that funny, [but] the alternative crop project was applied. [But,] it was a small application [designed] by small minds. It provided no benefits $[\ldots]$

The application period of the projects was short and the support payment was insufficient: it almost seemed that the project did not actually aim to replace tobacco with an alternative crop but to withdraw SAEs gradually from agriculture.

The WB and the ministry did not try to understand local conditions of tobacco producers. Where lack of irrigation water in the plots where tobacco was grown, alternative crop production was difficult, and therefore producers generally directed their resources to lowvalue added.

A number of tobacco producers in Adiyaman opted to grow higher added-value crop types. F17 (personal communication, September 6, 2014), a smallholder in Adiyaman, was one of those former tobacco producers:

We got support [payments] for [pomegranate] saplings, [...] in the first year, [but] nothing was [given to us] in the following years. But, for instance, they did not set up its market as encouraging it. You would plant pomegranate but sell to whom [and how]. There is not a cold storage [in hand]. They do not educate us, [I mean], the provincial agricultural directorate. Private firms do it, [I mean], pesticide firms, [...] to sell their pesticide in the end. [...] There is no cooperative in Adiyaman [to sell pomegranate]. [...] Now, there are around 30,000 decares of pomegranate orchards in Adiyaman, including large enterprises. Now, everyone is trying to install their own cold storage using their [financial] possibilities. The government supports [the instalment of] cold storages. However, I have 2000 [pomegranate] trees. If I thought of installing a cold storage, 40,000 liras would be gone. [...] [Actually] there is a certain time limit for storage. After four months later, [...] pomegranates in hand would be rotten. [...] Now, there is a firm in Adiyaman from Elazig; they will sell organic pomegranate juice to the Migros [supermarket chain] and out of Turkey. [...] but there is no price guarantee. He says "the average price for [a ton of] pomegranate in the market is 700 liras so I will buy it for 500 liras. If you want to sell it, do it or if not, don't sell it." [...] Everyone here is 
seeking to uproot their pomegranate trees], because there is no market for [pomegranates].

As understood, the WB and the ministry did not underpin the project with an extension programme that could have involved private and public extension staff, set up a mechanism to document the problems that those who engaged in the project would face or did face, improve the system with stakeholders to solve the emerging problems, and cooperate with them to build a sustainable sales cooperative for alternative crops.

\section{A Partly Unsuccessful Case: The Case of the Irrigation Unions in the Harran Plain}

The irrigation unions in the Harran Plain, which farmer members cooperatively administer via the board they select, have been responsible for over twenty five years of managing and maintaining irrigation water conveyed by open channels. As they fulfil their tasks, they maintain close contact with the provincial branch of State Hydraulic Works. No matter how much AEs in the Harran Plain have increased their agricultural income thanks to irrigation water, their irrigation unions have had serious problems limiting their effectiveness and causing the problem of waterlogging and salinisation.

Some of the problems, in fact, result from Turkey's existing institutional weaknesses. Although the country is endeavouring to adapt new global principles associated with socioeconomic development and water management, such as participation of stakeholders, good governance, and sustainability, there still exist institutional problems in water management: the inadequate awareness of environmental and economic aspects of water resources; the lack of coordination between public stakeholders in the water sector and; the confusing structure of domestic legal sources (Kibaroglu \& Sumer, 2007). These institutional problems are the main factors behind what would hamper the functioning of a polycentric governance system over water resources as common pool resource. For example, the inadequate awareness of environmental aspects of water resources combined with the hastiness of the incumbent government of getting political benefits. Agricultural producers in Harran that accessed irrigation water for the first time in their lives, used irrigation water exorbitantly, so caused the problem of waterlogging and salinisation, deteriorating agricultural lands. The government, at that time, had not listened to what experts recommended about the extension service and work quality that required substantial improvements (Van den Ban, 2000 cited in Jongerden, 2010a). In later years, a partnership between public organisations, universities and private agencies came into place to solve the problem; for example, drainage systems were started to be set up in agricultural lands to dispose water. However, as I was told during 
fieldwork, the problem of educating farmers about how to use water in crop cultivations is still continuing, despite all the efforts, in the areas where irrigation water have opened up.

According to E. Ostrom (2011, p. 90), the governance of common pool resources must be designed around and embedded in certain principles. To put it differently, those who have rights to appropriate benefits from those resources and the resource itself must be defined clearly with certain boundaries. The appropriation and provision rules in relation to local conditions, and the rules used for modifying these rules and for providing enforcement must be specified well through the participation of stakeholders. Monitoring and graduated sanctions must be fulfilled properly by keeping accountability to the appropriators. The appropriators and their officials must be able to access local agencies or courts that can solve conflicts between stakeholders. The external agencies must respect what rules the appropriators have designed.

Özerol (2013) uses Ostrom's institutional analysis method to understand the problem having arisen in the case of the irrigation unions in Harran, and she first ascertains that lack of water rights at plot and district levels is a major problem. Both the landowners and those who rent those lands have a right to access irrigation water, and this creates a problem.

In the plains of Sanliurfa which have agricultural irrigation systems, most of the large landholders traditionally work with sharecroppers. Under the sharecropping system, the provision of agricultural inputs and the decisions made about production fall under the responsibility of the large landholders. Sharecroppers are supposed to add their labour to the production process. As for the use of irrigation water in this system, most of the sharecroppers waste too much water (Mehmet Simsek, personal communication, July 22, 2015). Mehmet Simsek (personal communication, July 22, 2015), a professor at Harran University, explains how sharecroppers think about water use:

“[...] Citizens are responsible [for water-based problems about soil] with fifty per cent as well as the state with [the other] fifty per cent. [...] First, the educational level of farmers is low. No matter how much you increase literacy rate, in order to maintain a family-type agricultural enterprise and employ family work force, there must be the density of illiterate people so you can keep them. Second, I do not have any fields today; [I think] today I will stay here with the person $\mathrm{X}$ for three years. I see this field is not [appropriate] so I can go to another field. Therefore, I would not care the contamination of this field [due to excessive water use] [...]. It is because they think that I am not the owner of the field and that I have no expectation from here. If he somewhat has some 
faults in his character, he says: "never mind, let it get worse and let the landholder not gain anything". He would not lose [in this case], because there are many alternative fields for him. It is because there are a lot of needs for work force, so he has no problem with being unemployed. There is no situation to lose his income that year, because these decreases [in soil quality] expand within the long term."

The problem of excessive water use points to a bigger problem, that is, 'the low degree of alignment between the rules at different levels also results in "inappropriate" irrigation practices (Özerol, 2013). For example, users who are unable to access water conveyed through gravity, pump water from the main or secondary channels, an action that is prohibited by law. Again, the tail-end users are sometimes unable to access water during the irrigation season, and therefore, they have to withdraw salinized water from the drainage system (Özerol, 2013).

Furthermore, the participation of the farmer users in the seasonal planning of irrigation water procurement is limited and done by the DSI and the irrigation unions (Özerol, 2013). The appropriation needs of water by farmers does not match with the seasonal plan, and worse, monitoring, enforcing and sanctioning are frustrated by farmers and associations such that 'individual water use is not metered, neither aggregated to monitor the water use at the district level' (Özerol, 2013). What I learned during fieldwork was that the provisional activities such as repairing and cleaning canals are done by the unions through the fees collected from users, but the problem is that these unions lack financial and administrative transparency and accountability. Put it bluntly, the heads of irrigation unions are not equipped themselves with the required information and abilities for managing an irrigation union.

All these problems derive from the political economic terrain in the Harran Plain. Compared with other regions, the large landholders are key actors here who have a political tie with the state officials and the government thanks to being wealthy and having tribal power. In the Harran Plain, the majority of the population are of Arab-origin, and they have been long loyal to the state and the ruling party, and against the Kurdish political movement. In return, the large landholders controlling the tribal networks keep control of irrigation unions and the headship of villages, and thus, tribal nepotism plays a part in political and economic relationships (Özerol, 2013). It was claimed by one of my respondents that when the water is first released at the start of the season, it is arranged in tune with the water needs of large landholders, who prepare with the local administration of the DSI the seasonal irrigation planning related to when and how much water is required for agricultural lands (F15, 
personal communication August 26, 2015). Timing of watering plants matters highly in agricultural production, any delays could thus result in less productive yields for smallholders.

An official in the region (O17, personal communication, May 4, 2015) depicts the case well that the feudal system has disintegrated to a significant degree, but the region is now experiencing an interregnum between this old system and the modern one. The main source of this long-standing interregnum is about the conflict between the Turkish state and the Kurdish political movement. This political problem and the state formation help the tribal political power to sustain itself in the irrigation unions, blocking the democratic participation of the farmers in multi-layered collective action processes to improve the governance of the unions. E. Ostrom (2011) and Özerol (2013) never discuss how classes in the dominant coalition and the political economic terrain they face are determinants for collective action problems and the governance of common pool resources.

\subsubsection{Successful Cases of Government Interventions in the SAR}

We will look at two cases in this section to show that as long as government interventions are framed by approaching the polycentric governance, its likelihood of being successful will raise. The first case is about the use of IPARD grants to overcome the lack of capital in the SAR; the second case is about the support for fruit production in the SAR.

\section{The IPARD and the Expansion of Agro-Industries in the SAR}

Given that the total capital stock level of the region is limited - not surprising for a relatively less developed regional economy - the subsidisation of capital within the GAP through public-funded grants and economic incentive programmes created by the EU and the Turkish state have undeniably helped to improve the regional industrial base.

These suppliers of grants and economic incentives do inherently not intend to obtain material benefits such as interest payments. However, they have encountered uncertainty that poses risks, that is, the demanders may waste those resources granted. As Bates (2005, p. 74) highlights, 'the result is that suppliers and demanders of capital possess an incentive to cooperate in devising nonmarket means of providing assurances to investments'. In this sense, the EU and the Turkish government share the risks involved, that is, the former made a commitment to finance $75 \%$ of grant programmes and the latter $25 \%$. The investors who receive grants for their project are liable to pay $50 \%$ of the total investment costs, but banking companies facilitate their financial burden offering loans with low interest rates. 
The EU helped the Turkish government to adapt to the EU institutional framework for accurately conducting all the assessments required in the grant programme. The Agricultural and Rural Support Agency was established and its officials prepared strategy and implementation documents. ${ }^{118}$ As a result, the framework and strategies were adapted to local conditions by the local officials of the agency, preparing strategy reports in line with the GAP action plans that prioritise comparative advantages and consulting with local development agencies, the GAP-RDA, agricultural directorates and non-governmental organisations (O36, personal communication, May 7, 2015). When Turkey fulfilled the required tasks, procurement of grants were initiated in 2007 within the IPARD, which have significantly contributed to the solution of the problem of lack of capital in the SAR.

The private companies applying to grants are collaborating with the private advisory firms that prepare the projects at the EU standards to submit the applications successfully. The officials of the Agricultural and Rural Support Agency are providing the required legal and institutional information to stakeholders, and ranking their projects based on a point-based system and the technical reports written by experts from universities. In doing so, they must comply with the institutional framework adopted from the EU, and eventually committees from the EU and the government are auditing all the grants provided. The Agricultural and Rural Support Agency has a three-layer process to evaluate and enforce the projects: the preconfirmation process, the implementation process, and the post-implementation process lasting five years. They especially check if the firm is active in the post-implementation process, and if it is not active or violates the agreement, they sanction the firm; for example, they reclaim the total amount of grant with interest payments (O36, personal communication, May 7, 2015).

Looking at the practice of these grants, we can easily understand that the advisory firms that assume the responsibility of preparing the projects have developed their abilities over time. The success of receiving grants in the first invitation for bids was very low for Turkey $(9.8 \%)$ but far higher (77.5\%) in the twelfth invitation for bids (A. Koç \& Giray, 2015).

In the SAR, despite some coordination problems between local public organisations (TEPAV, 2013, p. 106), the grants are successfully bestowed to the establishment of new factories as well as the improvement of the current ones with new machineries and equipment

\footnotetext{
${ }^{118}$ See the website of Agricultural and Rural Support Institute for documents : http://www.tkdk.gov.tr/; and see the website of IPARD for international agreement between Turkey and the EU: https://ipard.tarim.gov.tr/mevzuat-tr
} 
(Cihangir, Bilgiç, \& Aba, 2015). The completion rate of the projects assisted is high (74\%), and the completed ones transitioned to the evaluation of post-implementation process ( $\mathrm{S}$. Aslan, Demirhan, \& Ertaş, 2016). The grants have mostly been allocated to the AEs and agro-industries that invest in the sub-sectors with comparative advantages. For example, in Mardin, investments were completed in meat and milk production and processing, beekeeping, halva production, corn drying, and the cultivation of ornamentals and medical plants (S. Aslan et al., 2016).

Studies about how the IPARD have influenced the SAR's economic development is limited. However, the study of Gülçubuk, Köksal, Ataseven, Gül, and Kan (2016) that examines the effect on the IPARD on Turkey's economic development gives us some insight. The investments within the scope of the IPARD have not only expanded the industrial capacity but also helped increase sales, raise productivity by the use of novel technologies and highquality inputs and develop local economies by stimulating local input suppliers and local human resources (Gülçubuk et al., 2016). Taking these advantages, investors are carefully selected, so to increase their chance to survive in the market. For example, a group of the investors who received this grant had already obtained a certain level of experience in the sub-sector they invested. The others committed to hire experienced employees. In this way, they proved that they could create a sustainable business. The point-based system of the grant programme impelled them to do so, which in turn assured the development of human resources in localities (Gülçubuk et al., 2016). More importantly, while agro-industries in the SAR have developed within the GAP (see the section 7.3.2), the IPARD grants have significantly contributed to these efforts. These grants have increased milk production by $4 \%$ in Sanliurfa and meat production by $20.5 \%$ in Diyarbakir and around $12 \%$ in Sanliurfa (Gülçubuk et al., 2016).

The EU authorities confirmed that 42 provinces of Turkey would be added to the IPARD grant programme. Sanliurfa, Mardin and Diyarbakir were three of these from the SAR. This impelled various stakeholders in the other provinces to put pressure on the government to create such a grant programme for their needs. The RDSP, therefore, came into practice in 2006, which were updated by the same logic several years later but without the EU's supervision and auditing. It is noteworthy that the programme has functioned well through the institutional capabilities of public organisations, developed as performing the IPARD.

The provinces of the SAR have highly benefitted from this program. Gaziantep and Sanliurfa have benefited the most of all provinces from the grants for investing in agro-processing and 
packaging; Adiyaman has been one of the seven provinces obtaining grants for fertilizer processing and packaging. Mardin has ranked first in making investments in agricultural storage facilities (Can, Sayılı, Yılmazçoban, \& Bilici, 2014).

The IPARD and the RDSP have been highly beneficial depending on the scale of capital owners, but the RDSP had at least helped all scales of AEs to improve their agricultural machinery and equipment pool until it was ended in 2016 because of the saturation AEs had reached in mechanisation.

The extension of agricultural irrigation equipment into the regional agriculture (see section 7.2.2) was the result of this programme. Apart from this, the number of agricultural machineries raised all over Turkey. As seen in Table 7.10, the SAR remained behind Turkey's average in changes in most of the agricultural machinery and equipment between 2000 and 2005. With the implementation of the RDSP, the SAR dramatically increased this, more than any other region in Turkey. It seems that the increase in the regional agricultural productivity we discussed earlier is related to increases in agricultural machineries and equipment through grants.

\begin{tabular}{|l|l|c|c|c|c|c|c|}
\hline Period & & Tractors & $\begin{array}{c}\text { Combine } \\
\text { Harvesters }\end{array}$ & $\begin{array}{c}\text { Tractor Disc } \\
\text { Ploughs }\end{array}$ & Cultivators & $\begin{array}{c}\text { Fertilizer } \\
\text { Broadcasters }\end{array}$ & $\begin{array}{c}\text { Milking } \\
\text { Machines }\end{array}$ \\
\hline \multirow{2}{*}{$2000-2005$} & Turkey & $8.55 \%$ & $-6.10 \%$ & $-0.11 \%$ & $7.37 \%$ & $10.50 \%$ & $50.91 \%$ \\
\cline { 2 - 8 } & The SAR & $4.72 \%$ & $-23.17 \%$ & $3.95 \%$ & $3.82 \%$ & $18.49 \%$ & $39.11 \%$ \\
\hline \multirow{2}{*}{$2005-2016$} & Turkey & $24.57 \%$ & $37.55 \%$ & $0.91 \%$ & $31.12 \%$ & $25.75 \%$ & $129.88 \%$ \\
\cline { 2 - 8 } & The SAR & $34.13 \%$ & $235.22 \%$ & $20.32 \%$ & $76.71 \%$ & $45.04 \%$ & $834.35 \%$ \\
\hline
\end{tabular}

Table 7.10 Percentage Changes in Agricultural Machineries Before and After the Introduction of the Rural Development Support Programme (Turkish Statistical Institute, 2018a)

The assistance of the EU authorities was key to improve the national and regional institutional and organisational capacity to execute the IPARD and the RSDP successfully. We should however note that the case shows that as long as the political intentions of the government and the content of the programmes are well matched, the programmes were successful. The government sought to strengthen ties with the region itself, especially with capitalists and the small-scale property owners who largely constitute their political base in the region. This was key to the plan that aimed at disintegrating the Kurds from the Kurdish political movement. They failed to do this, but the ruling party has remained the second most popular for party in the region. 


\section{Agricultural Support for Small Agricultural Enterprises for Fruit Production: Strawberry Production in Lice and Sason}

Since the mid-2000s the government and regional agricultural authorities have encouraged SAEs in fruit and vegetable production by granting financial support, certified seedlings and innovative irrigation equipment in addition to countrywide agricultural subsidies. As a result of cooperation with international organisations, grants are being given to SAEs for establishing modern fruit orchards; for example, the IPARD is being used for such a purpose, introduced by the EU. For the Diyarbakir, Batman and Siirt Rural Development Project, international assistance from the UNDP and the International Fund for Agricultural Development was obtained and has been used for SAEs which developed fruit yards with modern irrigation system. This support has been directed by scientific research conducted in the 1990 s by the GAP-RDA ${ }^{119}$. Universities, regional and national research centres, and regional development agencies were included in this programme to increase coordination and enhance farmers' adaptation to the production of new types of fruits through demonstration (The MOAF, 2012). Nevertheless, detailed or purposely-made scientific studies conducted by regional research bodies have generally benefited LAEs more than SAEs, as these have greatly focussed on grains, legumes, fodder plants, maize and cotton. ${ }^{120}$ However, studies about fruit production have gradually increased since 2005 .

To examine how state interventions have been made, and failed, for fruit production, we can take the case of state-supported strawberry production in Lice as an example. F2, ${ }^{121}$ a smallholder family in Lice, Diyarbakir who was selected as 'a leader farmer', and who lives from 25 decares of irrigated land, describes how such support failed:

F2a: We joined in the strawberry production project two or three years before. [...] But, strawberries dried out as a problem arose from the seedlings granted. Then, the project stopped. We installed here this drip irrigation system thanks to them. [...] Its cost was covered by the provincial agricultural directorate for the strawberry production project. But when strawberries dried out, we started to use [to produce] pepper, aubergine and bean for our consumption.

\footnotetext{
${ }^{119}$ For details, see website of The GAP Regional Development Administration, particularly the section of library and e-sources (http://yayin.gap.gov.tr/tum-yayinlar.html).

${ }^{120}$ The publication list of the GAP Agricultural Research Institute (2016) shows that studies on fruit and vegetables were started in 2005 but that their number is still lower than those for other crops. The same is true for the GAP International Agricultural Research Institute and Diyarbakir Plant Protection Institute.

${ }^{121}$ The focus group of F2 includes the mother (F2b) and a daughter (F2a) of a smallholder family. The daughter graduated from the Department of Agriculture at Dicle University in Diyarbakir.
} 
F2b: The seedlings dried out. When we planted strawberry again in the following year but could not gain [the desired] productivity, we removed strawberries.

F2a: The benefit left for us is about the irrigation system. [...] I went to the provincial agricultural directorate later. I informed them of the situation. "There is nothing we can do but there is a company in Mersin, so you can buy seedlings with your money", they said. But if they had applied this project- this was their fault, and there was nothing wrong with its cultivation-, they should have covered the cost [of buying new seeds], but they did nothing.

F3 (personal communication, July 14, 2015), a large landholder, explained his frustration: F3: [...] what is to be done from now on? Farmers must be educated here; a market guarantee is needed; [buyers] are needed here to get farmers to do agriculture here. $[\ldots]$ The provincial and town-level agricultural directorates must orchestrate all these tasks. At this point, qualified personnel are required. [...] Our provincial agricultural directorate visited and looked at [the case] that farmers in Kiziltepe or Derik, Mardin were tremendously making strawberry production. Then, they told me "make a list including 14 or 15 farmers that will be able to do this well". They provided us with a grant covering 100 per cent [of our cost]. The provincial and town-level directors are our friends. They contracted a man named as Haci A., who does not know how to do this business and $[\ldots]$ strawberry production $[\ldots]$. That man searched on the internet and found a firm located in Mersin or Antalya or Adana [selling strawberry seedlings]. [...] When time came to plant the strawberry seedlings, there were none of them here. They said that it had hailed and iced them, and did not give us any seedlings. The provincial director told me "you, tell the producers to plant tomatoes in the plots arranged for strawberry". Tomatoes were planted. They gave excessive amount of water to [the tomato plants] because of senseless use of the drip irrigation system; the [water] channel dried up. The required education had not been given [to the farmers]. Then, the [strawberry] seedlings were brought, but tomatoes were standing tall [meanwhile]. [...] 300,000 or 400,000 Turkish liras of state fund were squandered. Now, I am the only one who is doing this business; the remaining part of [strawberries] all dried up. They brought temporary workers from the Turkish Labour Agency. We all planted them. [...] All of the applications were made wrongly. As we had not known it, they did not get our opinion. [...] Our climate is not favourable for strawberry. [...][Still,] if farmers was participated [in every process] and made aware of it; if [strawberry production] was explained [well]; if demonstration was made; [if] soil analysis and climatic appropriateness were [taken into consideration], [such a project would be successful]. 
As can be deducted from the above, AEs were helped by governmental bodies to start innovative strawberry production in Lice, but they failed. The regional and local officials did not take local agricultural conditions and the views of local farmers into consideration when designing the strawberry production project in Lice. Worse, they could not find a competent contractor to distribute seeds to farmers in Lice and failed in carrying out and enforcing this operation properly. Today, there is no strawberry production in Lice (Turkish Statistical Institute, 2017b).

The case of Sason, Batman can be taken as a counter-example to show that local and regional bodies, their innovation and institutional capacity, and the active participation of farmers are important for initiating or diffusing innovative production methods or new types of crops. Strawberry production was funded in Sason with grants for certified seedlings and with irrigation equipment by the GAP-RDA at first in 2008-2009, and later between 2011 and 2015 within the scope of the Diyarbakir, Batman and Siirt Development Project.

Bad previous experiences and lack of trust seemed the biggest obstacle to collective action among farmers. The GAP-RDA encouraged farmers to participate in a discussion to verbalise their problems. During this discussion, farmers discovered that they had common problems with marketing their crops, and that it would be difficult to solve it without collective action. The organisation, thus, convinced the farmers of establishing the Batman Sason Strawberry Producers Union and provided them with an innovative extension service, named the GAPTEYAP (Demir Kaya, 2016a, p. 16). ${ }^{122}$ Today the Union is executing $90 \%$ of sales operation strawberry in Sason by disintermediating brokers, thereby helping farmers to raise their income (Demir Kaya, 2016a).

The GAP-TEYAP is still continuing to improve the strawberry cultivation in Sason. The staff initiated a five-year project in 2014 including grants to foster productivity and product quality and lay out a marketing strategy plan (Demir Kaya, 2016a). In the following years, the GAPTEYAP introduced low tunnel greenhouses to the farmers in Sason to improve the productivity of strawberry cultivation, protect crops against unfavourable weather conditions and extend the cultivation period, so raising income (Demir Kaya, 2016b, pp. 14-15).

F37 (personal communication, October 17, 2016), both a manager of the union and a smallholder, expressed that the authorities had cut down their investment costs by 50 to 70

\footnotetext{
${ }^{122}$ This system is an innovative, integrated and participatory extension system, with researchers cooperating with show-case farmers and subsequently farmers interacting with each other to learn how to do farming innovatively. The aim is to limit shortcomings of top-down extension approaches.
} 
per cent by providing grants. Thanks to this well-designed project, over 300 SAEs are still continuing strawberry production in Sason. Although they still need some support from the government such as for cold storage, they were thankful that the regional and local agricultural bodies had provided an efficient extension and advisory service and financial assistance for the strawberry production. ${ }^{123}$

The total land allocated for the strawberry production was 1.5 ha in 2008 . It dramatically increased over time and reached 300 ha in 2017 as a result of all the effort described. The production raised from 45 tonnes to 3300 tonnes between 2008 and 2017 (Turkish Statistical Institute, 2017b). Strawberry production in Sason shows that government interventions in the form of well-designed projects can contribute to local agricultural development.

\section{The Case of Kilis Organic Olive and Olive Oil Producers Union}

In Market and States in Tropical Markets, small-scale fruit producers who used to be squeezed out by interventionist policies were cultivating globally high-in-demand cash crops such as coffee, cocoa, tea, palm kernels and oil and sisal etc. (Bates, 2005, p. 11). As African governments offered lower prices for cash crops, producers shifted their production to food crops such grains with comparatively higher prices (Bates, 2005).

The case of the SAR follows what Bates describes. The SAR producers' way is to produce fruits with relatively higher prices that can be cultivated under rain-fed conditions. They also follow the same logic when choosing the fruit type they will cultivate.

As we mentioned earlier, the use of modern inputs such as pesticide and fertilizer started to be prevalent in the region after the armed conflict. Agricultural lands in the SAR are therefore less contaminated by pesticides than those in the West SAR. A large area of orchards is free from pesticides, and many smallholders are producing high value-added organic crops in their orchards, such as pistachio, olive, and pomegranate, for local and national markets.

There are however two problems with engaging in organic farming. The relative cost of acquiring a certificate that proves organic farming practices in production is much higher for SAEs and MAEs. They therefore always find it hard to meet the costs in the absence of subsidies (F7-F25, personal communication, July 24-July 8, 2015). Furthermore, limited

\footnotetext{
${ }^{123}$ Despite this successful operation, the union still needs public financial support to advance their marketing capacity by investing in cold storage as smallholding members of the union are not be able to collectively cover these cost. For this purpose, the union applied for financial aid to the agricultural bodies, which has successfully operated and enabled its members to derive more profit from strawberry production.
} 
interaction among the AEs involved in organic farming poses another important problem (Monis et al., 2012, pp. 50, 53).

To solve these problems, the GAP-RDA instigated a programme with the technical support of the United Nations Development Programme (the UNDP), development agencies, research bodies and universities to technically and financially encourage the establishment of producer unions for organic farming and to enhance competitiveness, know-how and collective action among producers through a clustering strategy (within the GAP Organic Agriculture Cluster Project). The potential of organic olive farming has easily attracted such supports in Kilis in this way.

After the privatisation of TEKEL, the wine factory ceased to purchase grapes from AEs of Kilis after 2013. The cultivated areas of wine grapes in Kilis fell by around $40 \%$ and its production by around 30\% between 2013 and 2017 (Turkish Statistical Institute, 2017b). Merchants have harnessed their oligopolistic power to reduce prices of wine grapes (F31, personal communication, July 3, 2015). With few options left, some SAEs are therefore uprooting their grape vineyards: the cultivation of grains and pulses is likely to result in a drop in their income and a possible failure to sustain their agricultural activities. A more profitable option is to plant olive trees; however, they need money to start an olive orchard and the first harvest only takes place after five or six years. However, different kinds of interventions are required for such a switch. After the alternative crop project designed by the WB within the ARIP, the government got the lesson in 2008 and started paying subsidies for setting up orchards to cultivate the fruit types with comparative advantages and marketing possibilities.

As a result of such efforts, the Kilis Organic Olive Producers' Union has been operating successfully in Kilis for seven years, an area where an influx of Syrian refugees has greatly shocked the socio-economic stability. The Union opened an organic olive oil production plant with the technical support of the UNDP and the GAP-RDA and the financial support of the United Nations High Commissioner for Refugees, which was equipped with machineries enabling cold-pressing instead of hot-pressing, standardisation and packaging (The UNDP, $2014,2015 b$ ). Increasing the quality of the olive oil this way, the Union was supported and educated with a marketing expert, who later created their website and brands, and obtained the required certificates that would render them competitive in markets (The UNDP, 2015a). 
All these efforts bear fruits. In 2011 the Union included 146 member AEs cultivating 1290 ha for organic olive and by 2016 the member number had risen to 345 AEs cultivating 2870 ha of land (Sinan Sahinalp, personal communication, February 7, 2017). The Union extended their farming practices to other olive producers to get higher prices for their products. That is, merchants used to sell the olives produced in Kilis for 4 or 5 liras per kg, paying lower prices to farmers than this level. The price of the olive has increased to the same level as that of the olive produced in the Aegean region in recent years (Çevik, 2018, p. 32). In Kilis, the total land allocated to olive production has consequently raised from around 18800 ha in 2008 to around 28040 ha in 2017 (an increase of 49\%) (Turkish Statistical Institute, 2017b).

\subsection{Conclusion}

This chapters addressed how neoliberal policies applied at the national level, and government interventions made within the scope of the GAP, assisted by national and international organisations, have influenced the agricultural development of the SAR.

When the region came out of the armed conflict, the neoliberal agricultural transformation started, and made difficult the regional adaptation to market-oriented modern agriculture. This is why the neoliberal policies applied within the ARIP (e.g. the production-non-required DIS payment, the withdrawal of cooperatives, and the privatisation of state monopolies, etc.) adversely affected the SAR more than it did the relatively more developed regions, as they brought the dramatic withdrawal of the state from subsidising agriculture. AEs needed to be supported more but the neoliberal policies with the ARIP did not allow this.

When the ARIP ended, its results were regarded as unproductive, and the government therefore relaxed neoliberal policies without completely abandoning it. In other words, the logic of neoliberal policies has been maintained across the country. The government specifically increased production-required subsidies, stimulating the SAR's agricultural production more than in relatively more developed regions. However, the share of the supports in GDP continued to be reduced in line with the neoliberal agricultural transformation.

The irrigation investments within the GAP and the other government interventions in the forms of projects and programmes achieved success to the extent that they rely on the polycentric governance approach. Whenever the government allows the participation of stakeholders (e.g. farmers, and local, regional and international organisations) in decision- 
making and implementation processes, the projects and programmes applied mostly have contributed to productivity gains.

As a result, costs of production have raised since 2001, and the problem is that AEs continued to receive relatively low prices because of free-market dynamics. The market is free for brokers, merchants, supermarkets, and agro-processors (mostly large landholders) when it comes to appropriate the great portion of the agricultural surplus produced by AEs resulting from productivity gains. For this reason, a decrease in the total land under cultivation has continued after the post-ARIP period but at lower rate than compared with the ARIP-period.

The neoliberal agricultural policies have not worked well, causing increasing costs and decreasing agricultural commodity prices. These policies benefit the members of the dominant coalition and squeeze the agricultural producers that cannot act collectively. It is a fact that the creation of non-farm jobs for rural people, transfer between family members living in urban and rural areas, and the informal social security network of the government over religious communities have cushioned the impacts of the neoliberal policies, so preventing the radicalisation of the rural people.

What Bates (2005) ignores in Markets and States in Tropical Africa is that elements of the dominant coalition, such as large landholders and various factions in the bourgeoisie, who enjoyed the developmentalist policies, have also enjoyed the neoliberal economic policies acting at the expense of urban workers and smallholders. Government interventions in agriculture, in fact, aim to blunt the irreversible migration of rural people to urban areas. When they are added to the working class and cannot find formal jobs, but rather find lowly paid informal jobs driving them to severe poverty and insecurity, they are more perceptive to radicalisation. This possibility forced the government to carry out projects and programmes in the SAR. Indeed, the Kurdish movement continued to expand itself to west Turkey through these rural-urban migrations. Before 2001 this phenomenon happened because of the armed conflict but it has continued, even after the fighting ended, because of the impacts of neoliberal policies. The net migration rate from the SAR to other regions decreased between 2000 and 2015 but remained negative. The rate of the East SAR is also more negative than the West SAR (Turkish Statistical Institute, 2015b).

The intention of undermining the Kurdish political movement in the region brought government interventions to forge and strengthen ties with Turkish and Arabic-origin capitalist classes and alienate Kurdish capitalists and smallholders. However, the expansion 
of agro-industries has driven AEs to engage more in market-based relationships but simultaneously being exploited. 


\section{Chapter 8: Conclusion}

\subsection{Introduction}

This research critically approached RCT from the aspects of state formation and development, highlighting that it has a predominately Western-centric perspective. As Western countries were the first to achieve security and prosperity, underpinned with wellfunctioning, enduring institutions, RCT scholars therefore have focussed on them. However, their approach to understanding less developed countries is generally based on the same western-centric perspective, that is, it generally focuses on countries with which the west had a colonial relationship, such as Latin America and African countries. Less developed countries that have transitioned from an empire to a modern one, thus having a different political and development past, are not deeply studied using the same framework. The research is a step to fill this shortcoming, using Turkey as a case study.

The research discusses two main theoretical issues with regard to state formation. The first one concerns Bates's argument that regional diversity shapes the political terrain and the use of power; elites at the centre find coercing regional elites more effective than cooperating with them, thus hampering development (Bates, 2017, p. 117). We have countered this argument, arguing that regionalism occurs when elites at the centre restrict the participation of elites and people in decision-making processes. The starting point for our argument was the historical development of the Kurdish Question up to present day, so we traced back to the foundation of Turkey and the Ottomans to comprehend state formation.

Turkey's political-economic and institutional heritage from the Ottomans is an important determinant in Turkey' state formation process and on its effect on development. Acemoglu and Robinson (2012, pp. 120, 216) are right in observing that the Ottoman sultan created extractive institutions under an absolutist regime, providing privileges for the dominant coalition and preventing innovators to grow in power. We have showed that the military bureaucratic class, which never allowed the rise of any regional power in Anatolia, embedded itself in the modern Turkish state when the Ottoman Empire collapsed. This class was the product of a pre-capitalist era and maintained its power in a capitalist political economic setting. What is remarkable here is that it created capitalist classes that are dependent on the state and/or the protection of the bureaucracy. In other words, state formation and its political pathway have generally been shaped by the long-existing military bureaucratic class. Clearly, there is a symbiotic relationship between the bourgeoisie and the military-bureaucracy. The 
outcome of this relationship is the highly centralised Turkish state that thwarts the participation of mass people in decision-making processes, and that subtracts systematic rents for the dominant coalition.

North et al. (2009) refer to the role of the military and its control in mature natural states, but this is insufficient for understanding the case of Turkey, as these authors only direct their attention to the mature-natural-state period of France and England. So the gap in knowledge (which this thesis addresses) is that there is no attention to the class-based character of the (military) bureaucracy in non-Western countries, with its ability to keep a monopoly over violence.

Violence and Social Orders by North et al. (2009) is an important study for our understanding as it provides a conceptual framework categorising states as limited-access orders (natural states) and open-access orders. This framework contributes to our understanding of how elites in natural states act, how the nature of intra-elite relationships make door-step conditions rational for them, and how a transition is realised to reach an open-access order. However, this study does ignore how the periphery can influence intra-elite relationships in the dominant coalition in a way that shapes the state. Similar to the studies of Acemoglu and Robinson (2012) and (Bates, 2001, 2017) people in the periphery are considered passive actors.

In our study we have addressed this issue with reference to the Kurdish Question by taking account of social capital and its effect on forming political collective action. The Kurdish political movement as an ethno-political collective action re-emerged in the 1960 s as a grassroots movement, rather than as an elite-movement. In a similar way, a conservative peripheral movement emerged among elites and people as a reaction to a modernising Turkey. The conflicting relationship between the periphery and the centre and its effects on the dominant coalition and Turkey's state formation were scrutinized in this thesis.

After the 2001 economic crisis sparked great popular discontent, the conflicting relationship between centre and the periphery became more tense. The research discussed the impact of this relationship on the political economy and in particular the SAR's development. Neoliberal policies that were initiated at the national-level as a result of the economic crisis were combined with development interventions in the SAR to appropriate political benefits. The effects of these policies on the regional agricultural development were closely examined in this study. 


\subsection{Findings}

The research looks at Turkey's political economy in a wider sense but specifically focuses on the Kurdish Question and agricultural development of the SAR to make a series of critical arguments against RCT.

In Chapter 5, the research answered the first research question: why has Turkey, since 2001, simultaneously implemented both neoliberal agricultural policies and governmental interventions for agricultural development in the SAR? Our findings showed that the intentional co-implementation of these policies in the same period is a derivative of the conflicting relationships within the dominant coalition and between the centre and the periphery.

The JDP government, the political representative of the conservative bourgeoisie and periphery, followed the neoliberal recipe to obtain support from international financers, political organisations and Turkey's secular bourgeoisie. International investors and creditors, satisfied with the neoliberal policy implementations of the government, provided capital to Turkey, which resulted in a booming economy. This neoliberal economic adaptation was also underpinned by an improved relationship with the West. The government improved its relationship with the EU and convinced it to commence with accession negotiations. It also developed a strategic partnership with the US for the latter's politics and operations in the Middle East. These policies have strengthened the JDP government in domestic politics and prevented the military bureaucracy from intervening in the government. The political contest between the government and the Euroasianist and Kemalist wing of the military ended in a victory of the JDP after the 2007 general election. Judicial operations to remove that wing were initiated after 2007 by the JDP government and by the Gulen movement that had kept their members in the state since the mid-1980s.

The Kurdish Question became a hotly debated topic in this relationship. The JDP government sought to initiate good relationships with Kurds in order to politically isolate the secular inclined people and the military in domestic politics. When the PKK resumed their attacks after the Iraq War, the military narrative became more dominant. In the $1990 \mathrm{~s}$, it had provided the military with the opportunity to silence different views and dominate Turkey's politics. Perceiving this threat, the JDP waited for the military to start to fail in its military operations. Then, they created democratic openings and dramatically increased the level of investments in the SAR. They gained the support from most ordinary Turks and Kurds, so 
managed to isolate the military. The increased developmental efforts in the region were thus a political tool for the JDP. The JDP became the second most popular party in the SAR since 2002 thanks to these policies, and was regarded as the only political power to stop the rise of the Kurdish political movement. This confronted the state bureaucracy with a dilemma: "if we do not support the JDP against the Kurdish political movement, the PKK will achieve its goal, so Turkey will be divided." The JDP benefitted from this dilemma and eliminated the option of the military narrative.

The development narrative underpinned with democratic openings and peace talks with the pro-Kurdish parties and the authorities of the PKK all contributed in gaining support among many ordinary Kurds to cut their ties with the PKK. The plan of the JDP government was to establish a federal republic, which was to include the Kurdistan Region of Iraq, thus amplifying Turkey's regional power. In line with the plan, the Kurdish political movements as peripheral movement were supposed to be disintegrated. Forging good relationship with the Kurdish bourgeoisie, as the weakest group in the dominant coalition, was considered key to becoming successful. To make this group more dependent on the state, the government substantially increased public investments and provided grants and other financial incentives to the Kurdish bourgeoisie. Turk-origin and Arab-origin capitalist classes in the SAR elements of the conservative bourgeoisie - were also supported by the government to balance out the Kurds.

As a result, the rise of two peripheral movements, those of the conservatives and the Kurds, has been leveraged by the conservatives and Kurdish capitalists, and the associated political elites, to shape the dominant coalition. This allowed for more political power and a higher share of rents. The Gulen movement and the Euroasianist and Kemalist wing in the military were removed from the dominant coalition over time. Particularly, the conservative groups gained some economic advantages at the expense of the secular periphery.

In previous chapters, we argued that the highly centralised state causes regionalism and a lack of security and prosperity, and that the transition to open access orders is more difficult in countries such as Turkey because of its imperial background. This is because the (military) bureaucracy with its incontestable capacity of violence does not allow such a transition. Neither the bourgeoisie did have the intention to control them and gain political power nor have the peripheral movements been successful in doing this. 
After the June 2015 election, Erdogan, facing the loss of electoral power, stopped the negotiations with the Kurdish political movement, and instead took military actions. But with the November 2015 election, he re-gained his power. However, a one-year prevalence of the military narrative in Turkey's politics resulted in a coup attempt. After the failed coup attempt in 2016, lead by the Gulen movement, Erdogan allied with the security-obsessed wing of the bureaucracy to keep and raise his power. This political alliance established an oppressive regime. As they have blocked political participation of the periphery through coercion, the pro-Kurdish parties, which had introduced country-wide policies during peace talks, retreated and focused on regional policies again.

In Chapter 7, we answered the second research question: how has the simultaneous implementation of neoliberal agricultural transformation and government interventions affected agricultural development of the SAR since 2001? A great part of the analysis was written as a response to Bates' Markets and States in Tropical Africa, which argues against government interventions and prefers free-market policies and the withdrawal of subsidies.

The 2001 economic crisis had a massive impact on the Turkish economy and society. To overcome the crisis, Turkey signed a standby agreement with the IMF and accepted to start a dramatic neoliberal agricultural transformation under the supervision of the WB. Obtaining debt from the IMF was contingent to carrying out the neoliberal policies at national level. The policies in the ARIP (e.g. the production-non-required DIS payment, the withdrawal of cooperatives, and the privatisation of state monopolies, etc.) negatively affected the SAR more than relatively better developed regions since 2009. When the ARIP ended, the government introduced production-based subsidies to support AEs and increased investments and farmer-level projects within the scope of the GAP. The result was observed to be positive, in that the SAR's agricultural production has grown more than in relatively more developed regions. Güven (2009) defines the agricultural policies after 2008 as a hybrid period reflecting a partial diversion from the neoliberal reforms. We argued that these policies were hybrid as they included production-based subsidies and output-based subsidies. However, we have showed that the share of support payments in GDP kept decreasing since 2001, which suggests a gradual removal of subsidies. Furthermore, the government has never reverted to subsidised purchases via cooperatives and the Turkish Grain Board, or to the establishment of state-funded agricultural processors competing with market actors. 
The neoliberal agricultural policies have manifested themselves in a contraction of land under cultivation, with a decrease in grain and pulses predominately responsible for this. They have also resulted in a decline in fallow lands, which has somewhat offset the contraction of cultivated lands, and an increase in fruit production, in particular by SAEs.

Production-based support and various agricultural projects and programmes after 2008 have stimulated the use of innovative inputs and helped raise productivity and agricultural surpluses as well as an increase in crop quality, which is important for agro-processors. One factor behind productivity increase is the public irrigation investments within the GAP. But despite all this, the decline in the share of total agricultural support in GDP is evident from the lack of subsidies. Where relative prices of inputs to outputs have increased, the lack of subsidies have hit AEs and caused the transfer of increasing agricultural surplus values to big input providers and their vendors. Neoliberal policies have forced AEs to get credits at market-interest rates from banking companies or at higher interest rates from informal creditors, such as brokers, merchants, input vendors, etc. These market actors have therefore seized the agricultural surplus value created by AEs

We have shown in Chapter 6 that the agricultural crop prices dramatically decreased after 1980. Market-oriented policies did not bring favourable prices and income levels for farmers. Domestic terms of trade worked also against farmers. AEs tended not to act collectively as they are large and dispersed group. When the government stopped supporting cooperatives, AEs found themselves standing alone in the market with an inability of influencing let alone dictating prices. Market actors such as merchants, brokers, supermarket and agro-processors were taking advantage of this under free market conditions at the expense of SAEs and MAEs. Free market conditions did not bring free competition; merchants, brokers and agroprocessors are now pre-setting crop prices and imposing these on AEs.

Privatisation has created negative results for AEs. The privatisation of electricity providers required to cut electricity subsidies, which caused agricultural productivity to decrease. Those who could not afford to lose productivity started to illegally use electricity for agricultural production. This resulted in a political conflict between privatised electricity providers and a category of farmers. The government responded to this problem by suspending agricultural support payments for those farmers, making some farmers to return to cultivating low valueadded crops. 
The privatisation of TEKEL has severely afflicted SAEs in the SAR. The government ceased subsidised tobacco purchases and introduced contract farming in tobacco. Big tobacco companies and leaf companies enjoyed decreased tobacco prices, and as they are mostly buying tobacco from western regions, the SAR has been affected more than other tobacco producing regions. Alternative crop production did not help the SAEs. Many SAEs started to produce and sell illicit loose tobacco to smokers. This marked a new political conflict in tobacco market, different from Olson's and Bates' argument. Neither the tobacco companies nor those who produce and sell illicit tobacco have solely suffered. The former obtained the market share of TEKEL and increased its profits; the latter is compensating their loss from the removal of subsidised purchases through illicit activities and the government collects some taxes and get votes from tobacco producers.

Finally, we showed that governmental interventions in the form of projects and programmes can be successful if they are designed well and in line with the poly-centric governance approach, which recommends the participation of stakeholders in their design. When international organisations engaged in the design and implementation of a programme, it produced good results as they generally give importance to the participation of stakeholders. However, the research has argued that in the absence of international organisations the government favoured large landholders rather than smallholders, as was for instance in the case of the Harran irrigation systems. This is because large landholders in the SAR, who are wealthy and invest in agro-industries and other sectors, are deemed as members of the dominant coalition.

It was found that a range of government interventions have generally created positive results in the SAR. When the government and regional bodies devise them, they generally follow a market-oriented logic. However, neoliberal policies naturally benefit capitalist classes at the expense of especially SAEs; they have absorbed a great part of the agricultural surplus generated by SAEs which use innovative inputs to raise productivity. The government has sought to cushion the adverse effects of neoliberalism by informal mechanisms alleviating the poverty of smallholders via religious networks and by the expansion of non-farm jobs, so offsetting the loss of votes.

\subsection{Suggestions for Future Academic and Practical Endeavours}

This research was designed to critically appraise RCT with regard to state formation and development. The main weakness of RCT is that its scholars neglect to closely look at 
countries with an imperial background such Turkey, Egypt, Iran, Russia, China, etc. The political dynamics in these countries must be thoroughly understood, and in particular the role of the (military) bureaucratic class.

The research assessed intra-elite relationships and the conflicting relationships between the centre and the periphery. Growing reactions from the periphery to the centre or the dominant coalition in every country is an observable phenomenon after the 2008 economic crisis. A recommendation is therefore that scientific investigations must not only focus on intra-elite relationships but also on the peripheral movements, their dynamics and effects on intra-elite relationships.

Neoliberal policies and their effects are hotly debated in academia. Scientific research must be deepened to comprehend to what extent these policies are effective to foster development, especially agricultural development. Government interventions must not be considered necessarily harmful for economies. The question of how we can devise development interventions in less developed countries must be fully explored and must be done empirically, as we did in this study. 


\section{APPENDICES}

\section{Appendix 1: Qualitative Interview and Focus Group Questions}

\section{Appendix 1a: Qualitative Interview Questions Asked Officials at Provincial}

Agricultural Directorates

1- How do you inform small and large agricultural enterprises of innovations in agricultural inputs? What kinds of activities do you generally do for this purpose? Do you believe that public and private extension systems work?

2- To what extent do small and large agricultural enterprises use non-certified seeds that have no guarantee for disinfection? What kinds of activities do you generally do for preventing them from using them? What do you think about the certified seed support?

3- What kinds of supports do you give to agricultural enterprises about certified, improved seeds? To what extent do smallholders adapt themselves to the use of certified seeds? What kinds of problems do they have?

4- Can the market provide seeds, seedlings and saplings to farmers appropriate for their ecological conditions and socio-economic circumstances? How do you help farmers? What kinds of activities do you carry out to prevent the market from selling such seed varieties? Do you carry out or inspect performance analyses of the seeds sold in the market? Do you inform agricultural enterprises of the results of such analyses?

5- How do you help farmers for soil analyses? What kinds of barriers prevent agricultural enterprises from getting soil analysis done? What kinds of supports do you give to agricultural enterprises about fertilizer and diesel? What do you think about certified fertilizer and diesel support payments?

6- What kinds of machineries and equipment do smallholders generally buy? Do they take advantage of grant programmes for machineries and equipment? What kind of barriers do they confront in benefiting from such grants?

7- Do you support smallholders about the use of common machinery pool?

8- To what extent do smallholders adapt themselves to the implementation of agricultural prescription in agricultural pest management? What do you think about their use of pesticides and their efforts for pest management control?

9- What kind of activities do you do for organic agriculture and good agricultural practices? To what extent do small and large agricultural enterprises adapt themselves 
to such activities? What do you think about support payments given for those activities?

10-Have the projects for diversifying agricultural crop cultivation become successful? If yes, what are the factors behind your success? If no, what are the factors behind your failures?

11- What kind of barriers do small and large agricultural enterprises confront, which want to access irrigation water or have already accessed irrigation water? Do agricultural enterprises in your province use modern irrigation methods and equipment? Do you help them learn how to irrigate?

12- Why do some agricultural enterprises not use irrigation water though they can access to it? How do you help irrigation unions in conducting their activities?

13-Do you have an understanding of integrating land consolidation and land improvement works? What have you done about these issues so far?

14- To what extent do agricultural enterprises prefer to operate under a company? What are the problems with incorporation?

15- What are the problems of agricultural enterprises with the market, the Turkish Grain Board and sales cooperatives?

16- Are contract farming and supply value chains prevalent in your province? If no, what are the problems? Do you provide any extension activities to farmers about such marketing possibilities? What are the factors behind failed and successful projects? What do you think about the regional agricultural marketing system?

17- What kind of activities do you carry out with other stakeholders in the agricultural system such as research bodies, universities, cooperatives, irrigation unions, etc.?

18- How have the water dispute, dams and reservoir constructions and irrigation projects affected agricultural enterprises in your province?

19-How have the Kurdish Question and the armed conflict affected agricultural enterprises in your province?

20- Would like to add extra comments to what we have talked?

Note that the similar types of questions were also asked or adapted to interviewees in other official and non-governmental organisation according to their tasks or activity areas. 


\section{Appendix 1b: Qualitative Interview and Focus Group Questions Asked Farmers}

\section{Questions about Agricultural Production and Sale}

1- How many decares of land do you have? Could you tell me about the general qualities of your agricultural enterprises?

2- Do you use certified, improved seeds? Why? What kind of problems do you generally face buying and using them? What do you think about the certified seed subsidy?

3- Do you get the soil analysis done? Why? What kind of problems do you generally face the soil analysis? What do you think about subsidies given for the soil analysis, fertilizer and diesel?

4- What are your problems with pesticide use and purchases, and pest control management? What do you think about the implementation of agricultural prescription for pesticide use?

5- Have you ever engaged in organic agriculture and good agricultural practices? What do you think about the subsidies given for these activities?

6- Do you cultivate alternative or new types of crops? What kinds of problems do you generally have with cultivating alternative or new types of crops?

7- Do you receive any loan for agricultural production? What kind of problems do you have with getting loans?

8- Do you benefit from grants for agricultural machineries and equipment? What do you think about such grants?

9- Do you receive extension services from public organisations or private organisations? What do you think about the subsidy given for private extension services?

10 - Have you ever used any machinery or equipment from a common pool?

11- What do you think about incorporation in agriculture?

12- What kinds of ways do you follow to access water used for agricultural activities? Have you ever benefitted from any grants for purchasing modern irrigation equipment?

13- Do you use information technologies for your agricultural activities?

14- How do you sell your agricultural crops? What kinds of problem do you have with selling your crops? Have you ever tried to sell your crops in an alternative way? How are your relationships with agricultural cooperatives and Turkish Grain Board?

15-What do you think about agricultural taxation? Do you think tax on agriculture hampers your activities? 
16- Would like to add extra comments to what we have talked?

\section{Questions about the Water Dispute and the Use of Water in Agriculture}

1- Have your agricultural activities been affected by the water dispute over the Euphrates and Tigris Rivers?

2- How have dam and reservoir constructions affected your agricultural activities?

3- Have you ever accessed the irrigation water provided in the scope of the South-eastern Anatolia Project? If yes, how could you benefit from the irrigation water, and what are your problems with accessing and using irrigation water? If no, what do you think about water works on agricultural irrigation?

4- How has the use of irrigation water influenced your agricultural activities in terms of innovations?

5- Could you share your experiences with irrigation unions?

6- Would like to add extra comments to what we have talked?

\section{Questions about the Relationship between the Kurdish Question and Agriculture}

1- Could you tell me about how the Kurdish Question has affected your agricultural activities?

2- Has the armed conflict harmed your agricultural enterprise, land, vineyard, orchards and agricultural facilities?

3- Have the Kurdish Question and the armed conflict affected the use of new or modern agricultural inputs such as certified improved seeds, fertilizers, pesticides, etc.?

4- Have the Kurdish Question and the armed conflict affected your lending money from banking companies?

5- Do you believe that you have not benefitted from public agricultural services because of the Kurdish Question, such as general services and extension services?

6- Have you ever experienced any problems as purchasing agricultural inputs from the market during the armed conflict?

7- How has the village guard system affected your agricultural activities?

8- How has the Kurdish Question affected the sale of agricultural crops in the market?

9- Did you have to leave your village because of the armed conflict? What have you experienced or learnt about agriculture in the cities to which you migrated?

10- Would like to add extra comments to what we have talked? 
Appendix 2: The Cities and the Towns Visited in the Fieldwork

Appendix 2a: The Entire List of the Cities and the Towns Visited

\begin{tabular}{|c|c|}
\hline Cities & Towns \\
\hline Adiyaman & Central District \\
\hline Adiyaman & Kahta \\
\hline Adiyaman & Samsat \\
\hline Batman & Central District \\
\hline Batman & Gercus \\
\hline Batman & Sason \\
\hline Diyarbakir & Sur \\
\hline Diyarbakir & Lice \\
\hline Diyarbakir & Silvan \\
\hline Diyarbakir & Yenisehir \\
\hline Diyarbakir & Cinar \\
\hline Gaziantep & Nizip \\
\hline Kilis & Polateli \\
\hline Kilis & Central District \\
\hline Mardin & Kiziltepe \\
\hline Mardin & Nusaybin \\
\hline Mardin & Derik \\
\hline Mardin & Central District \\
\hline Mardin & Midyat \\
\hline Sanliurfa & Siverek \\
\hline Sanliurfa & Central District \\
\hline Sanliurfa & Harran \\
\hline Sanliurfa & Hilvan \\
\hline
\end{tabular}


Appendix 2b: The List of Towns with High Conflict Rates and Those of Which Were Visited During the Fieldwork to Talk about the Kurdish Question (Marked in Yellow)

\begin{tabular}{|c|c|}
\hline Cities & Towns \\
\hline Sirnak & Merkez \\
\hline Sirnak & Uludere \\
\hline Diyarbakir & Silvan \\
\hline Sirnak & Cizre \\
\hline Sürt & Pervari \\
\hline Mardin & Nusaybin \\
\hline Sirnak & Idil \\
\hline Sirnak & Silopi \\
\hline Mardin & Midyat \\
\hline Batman & Sason* \\
\hline Mardin & Kiziltepe \\
\hline Sïrt & Eruh \\
\hline Diyarbakir & Lice \\
\hline Mardin & Dargecit \\
\hline Batman & Merkez \\
\hline Diyarbakir & Kulp \\
\hline Diyarbakir & Yenisehir \\
\hline Batman & Kozluk \\
\hline Sirnak & Beytussebab \\
\hline Mardin & Savur \\
\hline Siirt & Kurtalan \\
\hline Diyarbakir & Bismil \\
\hline Sïrt & Baykan \\
\hline Sürt & Sirvan \\
\hline Mardin & Omerli \\
\hline Batman & Gercus \\
\hline Diyarbakir & Sur \\
\hline Diyarbakir & Ergani \\
\hline Mardin & Mazidagi** \\
\hline Sirnak & Guclukonak \\
\hline
\end{tabular}

*I talked with a farmer in Sason about the Kurdish Question on the phone.

**I went to Derik of Mardin on the recommendation of the local people, instead of Mazidagi. They told me that Derik had been more affected than Mazidagi during the armed conflict. According to my data, Derik is slightly below the average conflict rate, thus being excluded from the list above. In fact, the difference between the two towns in terms of conflict rates is narrow. Based on this fact, I chose to listen to the local people and visited Derik, around 14 miles away from Mazidagi. 
Appendix 3: The Lists of the Interviewees

\begin{tabular}{|c|c|c|}
\hline \multicolumn{3}{|c|}{ The Complete List of the Officials Interviewed } \\
\hline Code & \begin{tabular}{|l|} 
Organisation \\
\end{tabular} & Inte rview Date \\
\hline $\mathrm{O} 1$ & Adiyaman Agricultural Directorate & 23 September 2014 \\
\hline $\mathrm{O} 2$ & Adiyaman Agricultural Directorate & 23 September 2014 \\
\hline $\mathrm{O} 3$ & Mardin Agricultural Directorate & 05 May 2015 \\
\hline $\mathrm{O} 4$ & Mardin Agricultural Directorate & 05 May 2015 \\
\hline $\mathrm{O} 5$ & Mardin Agricultural Directorate & 05 May 2015 \\
\hline $\mathrm{O6}$ & Sanliurfa Agricultural Directorate & 24 April 2015 \\
\hline $\mathrm{O} 7$ & Adiyaman Agricultural Directorate & 22 September 2014 \\
\hline $\mathrm{O} 8$ & Diyarbakir Agricultural Directorate & 24 September 2014 \\
\hline O9 & Gaziantep Agricultural Directorate & 30 September 2014 \\
\hline $\mathrm{O} 10-\mathrm{O} 37$ & Mardin Agricultural Directorate & 05 May 2015 \\
\hline $\mathrm{O} 11$ & Sanliurfa Agricultural Directorate & 28 April 2015 \\
\hline $\mathrm{O} 12$ & Adiyaman Agricultural Directorate & 19 April 2015 \\
\hline $\mathrm{O} 13$ & Gaziantep Agricultural Directorate & 30 September 2014 \\
\hline $\mathrm{O} 14$ & Mardin Agricultural Directorate & 04 May 2015 \\
\hline $\mathrm{O} 15$ & Sanliurfa Agricultural Directorate & 28 April 2014 \\
\hline $\mathrm{O} 16$ & Adiyaman Agricultural Directorate & 22 September 2014 \\
\hline $\mathrm{O} 17$ & Mardin Agricultural Directorate & 04 May 2015 \\
\hline $\mathrm{O} 18$ & Mardin Agricultural Directorate & 04 May 2015 \\
\hline $\mathrm{O} 19$ & Sanliurfa Agricultural Directorate & 29 April 2015 \\
\hline $\mathrm{O} 20$ & Diyarbakir Agricultural Directorate & 24 September 2014 \\
\hline $\mathrm{O} 21$ & Harran Agricultural Directorate & 27 August 2015 \\
\hline $\mathrm{O} 22$ & Kilis Agricultural Directorate (Conversation) & 20 April 2015 \\
\hline $\mathrm{O} 23$ & Adiyaman State Hydraulics Works & 06 July 2015 \\
\hline $\mathrm{O} 24$ & Sanliurfa State Hydraulics Works & 24 July 2015 \\
\hline $\mathrm{O} 25$ & Adiyaman Turkish Grain Board & 18 September 2014 \\
\hline $\mathrm{O} 26$ & Diyarbakir Turkish Grain Board & 26 September 2014 \\
\hline $\mathrm{O} 27$ & Dicle Development Agency & 07 May 2015 \\
\hline $\mathrm{O} 28$ & The Regional Directorate of the GAP & 28 July 2015 \\
\hline $\mathrm{O} 29$ & The Regional Directorate of the GAP & 28 July 2015 \\
\hline $\mathrm{O} 30$ & Gaziantep Ipekyolu Development Agency Office & 24 April 2015 \\
\hline $\mathrm{O} 31$ & Ipekyolu Development Agency & 24 May 2015 \\
\hline $\mathrm{O} 32$ & Ipekyolu Development Agency & 24 April 2015 \\
\hline $\mathrm{O} 33$ & Kilis Ipekyolu Development Agency Office & 21 April 2015 \\
\hline $\mathrm{O} 34$ & Kilis Ipekyolu Development Agency Office & 21 April 2015 \\
\hline $\mathrm{O} 35$ & The Ministery of Food, Agriculture, Livestock & 06 August 2014 \\
\hline $\mathrm{O} 36$ & Agricultural Rural Development Support Agency - Mardin Office & 07 May 2015 \\
\hline
\end{tabular}




\begin{tabular}{|c|c|c|c|}
\hline \multicolumn{4}{|c|}{ The List of the Farmers Interviewed } \\
\hline Code & City - Town & Type of Interview & Interview Date \\
\hline F1 & Diyarbakir - Sur & Individual Interview & 14 July 2015 \\
\hline F2 & Diyarbakir - Lice & Focus Group (2 people) & 14 July 2015 \\
\hline F3 & Diyarbakir - Lice & Individual Interview & 14 July 2015 \\
\hline F4 & Diyarbakir-Silvan & Individual Interview & 14 July 2015 \\
\hline F5 & S.urfa - Siverek & Focus Group (6 people) & 24 July 2015 \\
\hline F6 & S.urfa - Siverek & Individual Interview & 24 July 2015 \\
\hline F7 & Diyarbakir - Yenisehir & Focus Group (3 people) & 24 July 2015 \\
\hline F8 & Mardin- Kiziltepe & Individual Interview & 26 July 2015 \\
\hline F9 & Mardin-Nusaybin & Focus Group (3 people) ${ }^{1}$ & 26 July 2015 \\
\hline F10 & Mardin - Derik & Individual Interview & 27 July 2015 \\
\hline F11 & Mardin - Derik & Individual Interview & 27 July 2015 \\
\hline F12 & Mardin- Central District & Individual Interview & 27 July 2015 \\
\hline F13 & Batman-Gercus & Individual Interview & 28 July 2015 \\
\hline F14 & Mardin - Midyat & Individual Interview & 28 July 2015 \\
\hline F15 & Sanliurfa - Central District & Focus Group (3 people) & 26 August 2015 \\
\hline F16 & Adiyaman - Central District & Individual Interview & 29 August 2015 \\
\hline F17 & Adiyaman - Central District & Individual Interview & 06 September 2014 \\
\hline F18 & Adiyaman - Central District & Individual Interview & 05 July 2015 \\
\hline F19 & Adiyaman-Kahta & Conversation & 05 July 2015 \\
\hline F20 & Adiyaman - Central District & Individual Interview & 05 July 2015 \\
\hline F21 & Adiyaman - Central District & Individual Interview & 06 July 2015 \\
\hline F22 & Adiyaman - Samsat & Focus Group (3 people) & 07 July 2015 \\
\hline F23 & $\begin{array}{c}\text { Adiyaman- The Association of Tobacco } \\
\text { Producers }\end{array}$ & Focus Group ( 4 people) & 08 September 2014 \\
\hline F24 & Adiyaman - Kahta & Individual Interview & 07 July 2015 \\
\hline F25 & Adiyaman - Central District & Focus Group (2 people) & 08 July 2015 \\
\hline F26 & Gaziantep - Nizip & Focus Group (3 people) & 01 July 2015 \\
\hline F27 & Batman - Gercus & Conversation & 28 July 2015 \\
\hline F28 & Batman- Central District & Conversation & 28 July 2015 \\
\hline F29 & Diyarbakir - Yenisehir & Conversation & 13 July 2015 \\
\hline F30 & Gaziantep - Nizip & Individual Interview & 01 July 2015 \\
\hline F31 & Kilis - Polateli & Individual Interview & 03 July 2015 \\
\hline F32 & Kilis - Central District & Focus Group (3 people) & 20 April 2015 \\
\hline F33 & Mardin - Cenral District & Conversation & 26 July 2015 \\
\hline F34 & Sanliurfa - Harran & Individual Interview & 27 August 2015 \\
\hline F35 & \begin{tabular}{|l|} 
Sanliurfa - Hilvan \\
\end{tabular} & Conversation & 22 September 2014 \\
\hline F36 & Diyarbakir - Sur & Conversation & 24 June 2015 \\
\hline F37 & Batman- Sason & $\begin{array}{l}\text { Individual Interview } \\
\text { via Phone }\end{array}$ & 17 June 2016 \\
\hline F38 & Diyarbakir-Cinar & Conversation & 26 July 2015 \\
\hline
\end{tabular}

${ }^{1}$ It started as an individual interview but then turned to focus group with the participation of that villager's two sons, one of which is an agricultural engineer and the other is an urban dweller visiting his village in every summer. 


\begin{tabular}{|c|c|c|}
\hline \multicolumn{3}{|c|}{ The List of the Other People Interviewed that Play a Part in the Region's Agriculture } \\
\hline Code & Positions & Interview Date \\
\hline N1- Ahmet Fatih Simsek & Adiyaman Agricultural Credit Cooperative & 16 September 2014 \\
\hline $\mathrm{N} 2$ & Cukobirlik Agricultural Cooperative & 29 April 2015 \\
\hline $\mathrm{N} 3$ & Diyarbakir Agricultural Credit Cooperative & 25 September 2014 \\
\hline $\mathrm{N} 4$ & Kilis Agricultural Credit Cooperative & 20 April 2015 \\
\hline N5 & Adiyaman Chamber of Agriculture & 17 September 2014 \\
\hline N6 & The Association of Wheat Producers, Mardin & 08 May 2015 \\
\hline N7 & The Center of Chamber of Agriculture, Ankara & 07 August 2014 \\
\hline $\mathrm{N} 8$ & Adiyaman Chamber of Commerce & Email \\
\hline N9 & Diyarbakir Chamber of Commerce & 11 May 2015 \\
\hline N10 & Gaziantep Chamber of Industry & 22 April 2015 \\
\hline N11 & Gaziantep Chamber of Commerce & 01 October 2014 \\
\hline $\mathrm{N} 12$ & Kilis Chamber of Commerce and Industry & 21 April 2014 \\
\hline $\mathrm{N} 13$ & Sanliurfa Commodity Exchange & 30 April 2015 \\
\hline $\mathrm{R} 1$ & The Research Institute for Pistachio & 01 October 2014 \\
\hline R2 & The Institute of Agricultural Pest Control & 11 May 2015 \\
\hline R3 & GAP Directorate of International Agricultural Research & 29 April 2015 \\
\hline $\mathrm{R} 4$ & GAP Directorate of International Agricultural Research & 29 April 2015 \\
\hline R5 & GAP Directorate of International Agricultural Research & 29 April 2015 \\
\hline R6 & GAP Directorate of International Agricultural Research & 24 July 2015 \\
\hline R7 & GAP Directorate of International Agricultural Research & 24 July 2015 \\
\hline R9 & Gaziantep Techno Park (Personal Conversation) & 05 September 2014 \\
\hline Mehmet Simsek & Harran University & 22 July 2015 \\
\hline B1 & Private Advisory Company & 13 July 2015 \\
\hline B2 & CRC Electronic & 15 December 2014 \\
\hline B3 & Tarimsalpazarlama.com & 18 December 2014 \\
\hline
\end{tabular}




\section{Appendix 4: The Farmers Interviewed, Their Agricultural Enterprise Sizes and Land Utilisation}

\begin{tabular}{|c|c|c|c|c|c|}
\hline Code & City - Town & Type of Interview & Intervieews & AE Size & Land Utilis ation \\
\hline F1 & Diyarbakir - Sur & Individual Interview & Farmer & $800 \mathrm{da}(\mathrm{LAE})$ & Rain-fed Farming \\
\hline $\mathrm{F} 2$ & Diyarbakir - Lice & $\begin{array}{l}\text { Focus Group ( } 2 \text { people } \\
\text { from the same family) }\end{array}$ & $\begin{array}{l}\text { 1st- Agricultural engineer } \\
\text { (daughter) } \\
\text { 2nd- Farmer (mom) }\end{array}$ & 25 da (SAE) & Irrigated Farming \\
\hline F3 & Diyarbakir - Lice & Individual Interview & Farmer & $1000 \mathrm{da}(\mathrm{LAE})$ & Irrigated Farming \\
\hline $\mathrm{F} 4$ & Diyarbakir-Silvan & Individual Interview & $\begin{array}{c}\text { Farmer \& The owner of an } \\
\text { agroindustrial firm }\end{array}$ & 125 (SAE) & Rain-fed Farming \\
\hline F5 & S.urfa - Siverek & Focus Group (5 people) & Farmers & $\begin{array}{l}\text { 1st - } 100 \text { da (MAE) } \\
\text { 2nd - } 7 \text { da (SAE) } \\
\text { 3nd - } 12 \text { da (SAE) } \\
\text { 4th - } 9 \text { da (SAE) } \\
\text { 5th - } 8 \text { da (SAE) }\end{array}$ & $\begin{array}{l}\text { 1st - } 60 \text { da under Rain-fed } \\
\text { and } 40 \text { da under Irrigated } \\
\text { farming } \\
40 \text { da of his land is managed } \\
\text { by the informal pertnership } \\
\text { of all the farmers } \\
\text { the Others- Irrigated farming }\end{array}$ \\
\hline F6 & S.urfa - Siverek & Individual Interview & Farmer & $100 \mathrm{da}(\mathrm{MAE})$ & $\begin{array}{c}\text { Partly Rain-fed + } \\
\text { Partly Irrigated Farming }\end{array}$ \\
\hline F7 & Diyarbakir - Yenisehir & Focus Group ( 3 people) & $\begin{array}{l}\text { 1st- Farmer \& } \\
\text { Agricultural Input Seller } \\
\text { 2nd and 3rd - Farmer }\end{array}$ & $\begin{array}{l}\text { 1st- } 725 \mathrm{da}(\mathrm{LAE}) \\
\text { 2nd- } 1000 \mathrm{da}(\mathrm{lAE}) \\
\text { 3rd- } 1200 \mathrm{da}\end{array}$ & $\begin{array}{l}\text { 1st- Irrigated Farming } \\
\text { 2nd- Irrigated Farming } \\
\text { 3rd- } 240 \text { da under Irrigated } \\
\text { Farming; the Rest under } \\
\text { Rain-fed Farming }\end{array}$ \\
\hline $\mathrm{F} 8$ & Mardin- Kiziltepe & Individual Interview & Farmer & $50 \mathrm{da}(\mathrm{SAE})$ & Irrigated Farming \\
\hline F9 & Mardin-Nusaybin & Focus Group ( 3 people $)^{1}$ & $\begin{array}{c}\text { 1st - Farmer } \\
\text { 2nd - Agricultural Engineer } \\
\text { 3rd - The Farmer's Son }\end{array}$ & $60 \mathrm{da}(\mathrm{SAE})$ & Rain-fed Farming \\
\hline F10 & Mardin - Derik & Individual Interview & $\begin{array}{c}\text { Farmer + Official in the } \\
\text { Township } \\
\text { Agricultural Directorate }\end{array}$ & $\begin{array}{c}1400 \text { (LAE) } \\
\text { (Partly managed under } \\
\text { tenancy) }\end{array}$ & $\begin{array}{c}\text { Partly Rain-fed + } \\
\text { Partly Irrigated Farming }\end{array}$ \\
\hline F11 & Mardin - Derik & Individual Interview & Farmer & $660 \mathrm{da}(\mathrm{LAE})$ & $\begin{array}{c}\text { Partly Irrigated }+ \\
\text { Partly Rain-fedFarming } \\
\end{array}$ \\
\hline F12 & Mardin- Central District & Individual Interview & Farmer & SAE & Rain-fed Farming \\
\hline F13 & Batman-Gercus & Individual Interview & Farmer & $90 \mathrm{da}(\mathrm{SAE})$ & $\begin{array}{l}10 \text { da under Irrigated } \\
\text { Farming } \\
+80 \text { da under Rain-fed } \\
\text { Farming } \\
\end{array}$ \\
\hline F14 & Mardin - Midyat & Individual Interview & Farmer & $10 \mathrm{da}(\mathrm{SAE})$ & Irrigated Farming \\
\hline F15 & Sanliurfa - Central District & Focus Group (3 people) & Farmers & $\begin{array}{c}1 \text { st }-30 \text { da (SAE) } \\
\text { 2nd - } 110 \mathrm{da}(\mathrm{MAE}) \\
\text { 3rd - } 150 \mathrm{da}(\mathrm{MAE})\end{array}$ & Irrigated farming \\
\hline F16 & Adiyaman - Central District & Individual Interview & Farmer & $150 \mathrm{da}(\mathrm{MAE})$ & Irrigated Farming \\
\hline F17 & Adiyaman - Central District & Individual Interview & Farmer & $130 \mathrm{da}(\mathrm{SAE})$ & $\begin{array}{c}\text { Mostly Rain-fed Farming + } \\
\text { Partly Irrigated Orchard }\end{array}$ \\
\hline F18 & Adiyaman - Central District & Individual Interview & Farmer & $60 \mathrm{da}(\mathrm{SAE})$ & Rain-fed Farming \\
\hline F19 & Adiyaman-Kahta & Conversation & Farmer & $180 \mathrm{da}(\mathrm{MAE})$ & Rain-fed Farming \\
\hline $\mathrm{F} 20$ & Adiyaman - Central District & Individual Interview & Farmer & $200 \mathrm{da}$ (MAE) & Irrigated Farming \\
\hline $\mathrm{F} 21$ & Adiyaman - Central District & Individual Interview & Farmer & $130 \mathrm{da}(\mathrm{SAE})$ & $\begin{array}{c}\text { Orchard }+ \\
\text { Rain-fed farming land }\end{array}$ \\
\hline $\mathrm{F} 22$ & Adiyaman - Samsat & Focus Group (3 people) & Farmers & $\begin{array}{c}1 \text { st - 90da (SAE) } \\
2 \text { st - } 50 \text { da (SAE) } \\
\text { 3rd- } 200 \text { (MAE) }\end{array}$ & Rain-fed Farming \\
\hline $\mathrm{F} 23$ & $\begin{array}{l}\text { Adiyaman- The Association } \\
\text { of Tobacco Producers }\end{array}$ & Focus Group (4 people) & $\begin{array}{c}\text { 1st Farmer \& The Head of } \\
\text { the Association } \\
\text { the Others - Farmers }\end{array}$ & $\begin{array}{c}\text { 1st }-100 \mathrm{da}(\mathrm{MAE}) \\
\text { the Others }-<50 \mathrm{da} \\
(\mathrm{SAE})\end{array}$ & 1st - Irrigated Farming \\
\hline
\end{tabular}




\begin{tabular}{|c|c|c|c|c|c|}
\hline F24 & Adiyaman - Kahta & Individual Interview & Farmer & $60 \mathrm{da}(\mathrm{SAE})$ & Rain-fed Farming \\
\hline F25 & Adiyaman - Central District & Focus Group (2 people) & $\begin{array}{c}\text { 1st - Farmer \& } \\
\text { Head of the Village } \\
\text { 2nd- Farmer }\end{array}$ & $\begin{array}{c}350 \mathrm{da}(\mathrm{MAE}) \\
100 \text { (SAE) }\end{array}$ & Rain-fed Farming \\
\hline F26 & Gaziantep - Nizip & Focus Group (3 people) & Farmers & $\begin{array}{l}\text { 1st - } 10 \text { da orchard + } \\
\text { around } 40 \text { da non- } \\
\text { irrigated land (SAE) } \\
\text { 2- } 10 \text { da (SAE) } \\
\text { 3- } 15 \text { da (SAE) }\end{array}$ & $\begin{array}{c}\text { Non- Irrigated } \\
\text { Pistachio Orchard }\end{array}$ \\
\hline F27 & Batman - Gercus & Conversation & Farmer & Around $80 \mathrm{da}(\mathrm{SAE})$ & Rain-fed Farming \\
\hline F28 & Batman- Central District & Conversation & Farmer & SAE & Irrigated Farming \\
\hline F29 & Diyarbakir - Yenisehir & Conversation & Farmer & SAE & Irrigated Farming \\
\hline F30 & Gaziantep - Nizip & Individual Interview & Farmer & $120 \mathrm{da}(\mathrm{MAE})$ & $\begin{array}{l}20 \text { da Irrigated Orchard } \\
100 \text { da Rain-fed Farming }\end{array}$ \\
\hline F31 & Kilis - Polateli & Individual Interview & $\begin{array}{c}\text { Farmer+ the Owner of a Shop } \\
\text { in the City Centre }\end{array}$ & 70 da (SAE) & $\begin{array}{c}\text { Orchard and Vineyard } \\
\text { (Rain-fed) }\end{array}$ \\
\hline F32 & Kilis - Central District & Focus Group (3 people) & $\mid \begin{array}{c}\text { 1st - Farmer } \\
\text { 2st Farmer } \\
\text { 3rd- Official in an Agricultural } \\
\text { Credit Cooperative }\end{array}$ & $\begin{array}{l}\text { 1st - } 200 \mathrm{da}(\mathrm{MAE}) \\
\text { 2nd- } 3000 \mathrm{da}(\mathrm{LAE})\end{array}$ & $\begin{array}{c}\text { 1st - Partly Rain-fed } \\
+ \text { Partly Irrigated Farming } \\
\text { 2nd- Rain-fed Farming }\end{array}$ \\
\hline F33 & Mardin - Cenral District & Individual Interview & The Son of a Farmer & SAE & Orchard \\
\hline F34 & Sanliurfa - Harran & Individual Interview & Farmer & 360 da (LAE) & Irrigated Farming \\
\hline F35 & Sanliurfa - Hilvan & Conversation & Farmer & SAE & Irrigated Farming \\
\hline F36 & Diyarbakir - Sur & Conversation & $\begin{array}{c}\text { Farmer \& Advisor } \\
\text { in an Agricultural Investment } \\
\text { Advisory Firm }\end{array}$ & 60da (SAE) & Rain-fed Farming \\
\hline F37 & Batman- Sason & $\begin{array}{c}\text { Individual Interview } \\
\text { via Phone }\end{array}$ & Farmer & SAE & Irrigated Farming \\
\hline F38 & Diyarbakir-Cinar & Conversation & Farmer & $60 \mathrm{da}$ (SAE) & Irrigated Farming \\
\hline
\end{tabular}




\section{Appendix 5: Consent Form}

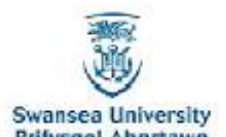

Prifysgol Abertawe

\section{A Political Economy Analysis of the Agricultural Structure of South-eastern Anatolia Region of Turkey}

Please check the appropriate box

Participartion in The Research

I read and understand the research document prepared on $17^{\text {th }}$ August 2014.

I was given to an opportunity to ask question about the research

I accept to participate in the research. By doing so, I accept to be interviewed and my voice or picture to be recorded.

I understand this voluntary participartion and accept it. I could always leave the interview and do not have to inform the reason why I have left.

To Use only for This Research

I understand that mu phone number and address will not be given any person out of this research

I understand and accept my words will be used in publications, reports, web page and other research materials.

Please select one of the following options

I accept my real name to be used for the research mentioned above

I would like to be an anonym person with regard to the research mentioned above

I accept to give Ulas Inci all types of rights over any material with regard to this research.

\begin{tabular}{llll} 
& & & Date \\
\hline Researcher & & & \\
Contact Detaile. & & & Date \\
Email: & & &
\end{tabular}




\section{Appendix 6: Research Information Document}

\section{Research Information Document}

\section{Introduction}

I am doing a PhD education in the Department of Politics and Cultural Studies at Swansea University. I intend to complete my doctoral research to graduate from the university

\section{What is the Aim of the Research?}

The aim of this research is to examine agricultural activities of small agricultural enterprises in the South-eastern Anatolia Region in term of producing for and sell to markets innovatively. By doing so, I will critically assess rational choice theory from the innovation systems approach.

\section{How Do I Conduct This Research?}

I employ qualitative interview technique and focus group technique for this research. I will discuss which technique will be applied to you prior to starting our discussion. If you accept it, I am interviewing you and record the entire interview made through voice recording machines or camera. Later on, if you give me consent, I can request for making an additional interview.

\section{The Disadvantages of Your Participation}

As I protect your anonymity, there will be no disadvantages to you. If the participant would like to accept the end of anonymity, I could mention your name in any relevant publication and written materials.

\section{The Advantages of Your Participation}

If you participate into this research, you can express your opinions and contribute to my research. You could also get recommendations about your activity area.

\section{What Will Happen When the Research Is Done}

When the research is done, its results will be placed in the literature as a doctoral research. Other researcher can use the research for various purposes. Furthermore, the results will be shared with public organisations.

\section{Do I Have to Participate It?}

You do not have to participate in this research. You can leave the interview for no reasons. If you do that, you will not be faced any legal problem. 


\section{What If I Encounter a Problem?}

If you have any concern or complaint, please contact with Ulas Inci

(743289@swansea.ac.uk).

\section{Will My Anonymity be Protected?}

Yes. It relies on your consent. Nobody use the data except for the researcher interviewed with you. The data will be kept in a computer with a password protection, and will be stored in accord with the legal framework of Turkey and the United Kingdom (Data Protection Act 1998).

\section{Who is Financing This Research?}

Swansea University and Republic of Turkey Ministry of National Education

\section{Contact Details:}

Temel Araşturmac1

Ulaş İnci

Politics and Cultural Studies Department

Keir Hardie Building

Swansea University

Singleton Park

Swansea, SA2 8PP

Wales.UK

Email:

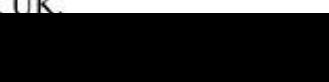

Main Supervisor

Krijn Peters

Politics and Cultural Studies Department

Keir Hardie Building

Swansea University

Singleton Park

Swansea, SA2 8PP

Wales, UK.

Email:

Telefor 


\section{BIBLIOGRAPHY}

2008 Yılı Ürünü Hububat ve Baklagil Üreticilerine Destekleme Primi Ödenmesine Dair Bakanlar Kurulu Kararı Uygulama Tebliği [The Application Notice of the Decision of the Cabinet on The Payment of Premium Support to The Producers of Grains and Pulses in 2008], 2008/68, The Official Gazette (The General Directorate of Legislative Development and Publication 2008 November 14).

Acemoglu, D., \& Robinson, J. A. (2005). Economic Origins of Dictatorship and Democracy (1st ed.). Cambridge: the UK: Cambridge University Press.

Acemoglu, D., \& Robinson, J. A. (2012). Why Nations Fail: The Origins of Power, Prosperity and Poverty (1st ed.). London, the UK: Profile.

Acikgoz, N. (2005, 9-11 November 2005). Hızla Değişen Gıda Tüketimi Karşısında Yeni Tohumculuk Stratejilerimiz Ne Olmalı? [What Is Our Strategy for Seed Production to Be towards Rapidly Changing Food Consumption?] Paper presented at the Turkiye Ikinci Tohumculuk Kongresi [The Second Turkey Congress on Seed Growing] Adana, Turkey.

Adıyaman Tütünü Pkk'ya Yar Olmaz [The Adiyaman Tobacco Would Not Belong to the PKK]. (June 29, 2017). Aksam. Retrieved from https://www.aksam.com.tr/guncel/adiyaman-tutunu-pkkyayar-olmaz/haber-638269

Ágoston, G. (1999). Ottoman Warfare in Europe 1453-1826. In J. Black (Ed.), European Warfare 1453-1815 (pp. 118-144). London: Macmillan Education UK.

Ahmad, F. (1993). The Making of Modern Turkey (1st ed.). London : the UK: Routledge.

Ahn, T., \& Ostrom, E. (2002, August-September). Social Capital and The Second-Generation Theories of Collective Action: An Analytical Approach to The Forms of Social Capital. Paper presented at the 2002 Annual Meeting of the American Political Science Association, Boston: the US.

Ahn, T., \& Ostrom, E. (2008). Social Capital and Collective Action. In D. Castiglione, J. W. Van Deth, \& G. Wolleb (Eds.), The Handbook of Social Capital (1st ed.). Oxford, the UK: Oxford University Press.

Akça, E., Sasaki, D., \& Fujikura, R. (2017). An Unexpectedly Successful Resettlement: The Atatürk Dam Resettlers to Western Turkey. Asian Journal of Environment and Disaster Management, 9(1), 39-48.

Akçadağ Alagöz, E. (2011, 24 Haziran). Avrupa Yerel Yönetimler Özerklik Şartı ve Türkiye. Retrieved from Retrieved from http://www.bilgesam.org/incele/753/-avrupa-yerel-yonetimlerozerklik-sarti-ve-turkiye/\#.WseBEy7wYdV

Akkaya, A. H., \& Jongerden, J. (2011). The PKK in the 2000s: Continuity through Breaks? In M. Casier \& J. Jongerden (Eds.), Nationalisms and Politics in Turkey: Political Islam, Kemalism and the Kurdish Issue (1st ed.). Oxon: Routledge.

Aksan, V. H. (2006). Ottoman to Turk. International Journal, 61(1), 19-38. doi:http://dx.doi.org/10.1177/002070200606100102

Aktan, I. (2006) Türkiye'nin Enerji Politikasi ve Özelleşen Elektrik [The Privatised Electricity Market and Turkey's Energy Policy] /Interviewer: K. Ulusaer. The Journal of Express, 64, Retrieved January 21, 2016 from http://www.emo.org.tr/ekler/07030ca685076c0 ek.doc?tipi=5\&turu=X\&sube=0

Aktas, E., Aka, A., \& Demir, M. C. (2008). Kinship (Hemsehri) Associations and Rural Transformation in Turkey (MRA Paper No. 8646). Retrieved from https://mpra.ub.uni-muenchen.de/8646/

Aktaş, E., İpek, S., \& Işık, S. (2010). Türkiye'de Tarım Sektöründe Kullanılan Mazota Yönelik Vergi ve Destekler [Taxes and Subsidies for Diesel Fuel Used in Turkey's Agricultural Sector]. Tarim Ekonomisi Dergisi, 16(1-2), 19-24.

Alchian, A. A. (1950). Uncertainty, Evolution, and Economic Theory. Journal of Political Economy, 58(3), 211-221.

Ankara Commodity Exchange. (2016). Dünya Bulgur Pazarı ve Türkiye [The World Bulgur Market and Turkey]. Retrieved from https://www.ankaratb.org.tr/solmenu goster.php?ld=52 
Ankara Commodity Exchange. (2018). Türkiye'de ve Dünyada Unlu Mamüller Ticareti [The Trade of Baked Products in Turkey and the World]. Retrieved from https://www.ankaratb.org.tr/solmenu goster.php?ld=52

Arksey, H., \& Knight, P. (1999). Interviewing for Social Scientists (1st ed.). London: the UK, California: the US, New Delhi: India: Sage Publications.

Arpac, O., \& Bird, G. (2009). Turkey and the IMF: A Case Study in the Political Economy of Policy Implementation. The Review of International Organizations, 4(2), 135-157. doi:10.1007/s11558-008-9051-4

Arrighi, G. (2007). Adam Smith in Beijing: Lineages of the Twenty-First Century (1st ed.). London: Verso.

Artigercek. (2018, 04 June). AKP'li Başkan: Oy Vermezlerse Işsiz Bırakmak Boynumun Borcu [The Mayor of the JDP: If They Do Not Vote for Erdogan, Then Dismissing Them Is My Binding Duty]. Artigercek. Retrieved from https://www.artigercek.com/haberler/akp-li-baskan-oyvermezlerse-issiz-birakmak-boynumun-borcu

Asik, G. A. (2012). Türkiye'de Kadınların İsgücüne Katılımı [Labourforce Participation Rate of Women in Turkey]. Retrieved from http://www.tepav.org.tr/en/yayin

Aslan, B., \& Demir Kaya, H. (2017). Coğrafi İşaretli Ürünler ve Güneydoğu Anadolu Bölgesindeki Durum [Products with Geographical Indication and Their State in the South-eastern Anatolia Region]. Gap Teyap Dergisi, 8, 2-7. https://www.gapteyap.org/dokumanlar/dergilerimiz.

Aslan, S., Demirhan, Y., \& Ertaş, M. (2016). Avrupa Birliği Katılım Öncesi Mali Yardım Aracı Kırsal Kalkınma Bileşeni (IPARD I) ve Mardin İline Etkileri [Eu Pre-Accession Assistance For Rural Development Component (IPARD I) and The Effect To Province of Mardin]. Akademik Yaklaşımlar Dergisi, 7(1), 232-254.

Ataay, F. (2001). Türkiye Kapitalizminin Mekansal Dönüşümü [The Locational Transformation of Turkey's Capitalism]. Praksis, 2, 53-96.

Atasoy, Y. (2013). Supermarket Expansion in Turkey: Shifting Relations of Food Provisioning. Journal of Agrarian Change, 13(4), 547-570. doi:doi:10.1111/j.1471-0366.2012.00382.x

Ates, H. C., Yilmaz, H., Demircan, V., Gul, M., Ozturk, E., \& Kart, M. Ç. O. (2017). How did post-2000 agricultural policy changes in Turkey affect farmers? - A focus group evaluation. Land Use Policy, 69, 298-306. doi:https://doi.org/10.1016/j.landusepol.2017.09.029

Ay, A., \& Yapar, S. (2005). Dünya Ticaret Örgütü Tarım Anlaşması ve Türkiye. Selcuk Unıversıtesi Sosyal Bilimler Enstitusu Dergisi, 13, 57-80.

Aydemir, S. S. (2000). Menderes'in Dramı [The Tradegy of Menderes] (7th ed.). n.p.: Remzi

Aydin, Z. (2005). The Political Economy of Turkey (1st ed.). London: the UK, Ann Arbor: Michigan, the US: Pluto Press.

Aysu, A. (2013). Türkiye Tarımının Serbest Piyasaya Uyarlanması ve Küçük Çiftçiliğin Tasfiyesi [The Adaptation of Turkey's Agriculture to the Free Market and The Liquidation of Smallholder Farming]. Perspectives, 6(13), 14-21.

Aytekin, A. (2013). Osmanlı-Türk Modernleşmesinin Düşünsel, Ekonomik ve Bürokratik Kodları. SDÜ Fen Edebiyat Fakültesi Sosyal Bilimler Dergisi, 30, 313-329.

Baday Yildiz, E., Sivri, U., \& Berber, M. (2012). Türkiye'de Illerin Sosyoekonomik Gelişmiş̧lik Sıralaması 2010 [The Ranking of Cities in Turkey in Terms of Socio-economic Development). Erciyes Üniversitesi iktisadi ve Idari Bilimler Fakültesi Dergisi,, 39(1), 147-167.

Banerjee, A. (2015). Neoliberalism and its Contradictions for Rural Development: Some Insights from India. Development and Change, 46(4), 1010-1022. doi:doi:10.1111/dech.12173

Basaran, E. (2011. 5 December). Kürt Burjuva Pkk'yı Ne Tam Olumlar Ne Reddeder [The Kurdish Bourgeoisie Neither Affirm the PKK Nor Deny It]. Radikal. Retrieved from http://www.radikal.com.tr/yazarlar/ezgi-basaran/kurt-burjuva-pkkyi-ne-tam-olumlar-nereddeder-1071530/

Başkaya, F. (1991). Paradigmanın Iflası: Resmi Ideolojinin Eleştirisine Giriş [The Bankruptcy of the Paradigm: Introduction to a Critique of the Official Ideology] (1st ed.). Istanbul, Turkey: Doz. 
Bates, R. H. (1983). Essays on the Political Economy of Rural Africa (1st ed.). New York: the US: University of California Press.

Bates, R. H. (1989/2005). Beyond the Miracle of The Market: The Political Economy of Agrarian Development in Kenya (3rd ed.). New York: the US: Cambridge University Press.

Bates, R. H. (2001). Prosperity and Violence: the Political Economy of Development (1st ed.). New York: the US; London: the UK: W.W. Norton.

Bates, R. H. (2005). Markets and States in Tropical Africa: The Political Basis of Agricultural Policies (2nd ed.). Berkeley, California: the US; London: England: University of California Press.

Bates, R. H. (2008). When Things Fell Apart (1st ed.). Cambridge, the UK: Cambridge University Press.

Bates, R. H. (2017). The Development Dilemma: Security, Prosperity, and a Return to History (1st ed.). Princeton: the US: Princeton University Press.

Bayar, A. H. (1996). The developmental state and economic policy in Turkey. Third World Quarterly, 17(4), 773-786. doi:10.1080/01436599615371

Baydin, A. G. (2006). Blank Map of Republic of Turkey's Provinces. In: Retrieved 26 September, 2018 from https://commons.wikimedia.org/wiki/File:BlankMapTurkeyProvinces.png . Creative Commons Attribution-Share Alike 3.0 Unported.

Baydur, C. M. (2015). Post Keynesgil Makro Açıdan Türk Tarımında Enflasyon [The Turkish Agriculture Inflation of Post Keynesian Perspective]. Çankırı Karatekin Üniversitesi Iktisadi ve Idari Bilimler Fakültesi Dergisi, 5(2), 749-762.

Becchio, G., \& Leghissa, G. (2017). The Origins of Neoliberalism: Insights from Economics and Philosophy (1st ed.). Oxford: the UK; New York: the US: Routledge.

Becker, G. (1986). The Economic Approach to Human Behavior. In J. Elster (Ed.), Rational Choice. Oxford: The UK: Basil Blackwell.

Beris, H. E. (2008). Türkiye'de 1980 Sonrası Devlet Sermaye iliş̧kileri ve "Parçalı Burjuvazi"nin Oluşumu [The State-Capital Relations After 1980 and The Formation of Partial Bourgeoisie in Turkey]. Ekonomik Yaklasim, 19(69), 33-45.

Besikci, I. (1970). Doğu Anadolu'nun Düzeni: Sosyo-Ekonomik Etnik Temeller [The Order of the Eastern Anatolia: Socio-Economic and Ethnic Foundations] (2nd Ed.). Ankara, Turkey: e.

Besikci, I. (1990). Devletlerarasi Somurge Kurdistan [Kurdistan : An Interstate Colony] (1st ed.). Istanbul, Turkey: Alan

Bienefeld, M. (1988). Dependency Theory and the Political Economy of Africa's Crisis. Review of African Political Economy(43), 68-87.

Bilgen, A. (2014). Katı Bir Bağ mı, Dinamik Bir Ağ mı? Güvenlik ve Kalkınma llişkisini Güneydoğu Anadolu Projesi (GAP) Bağlamında Yeniden Yorumlamak [A Static Nexus or a Dynamic Network Rethinking the Security Development Relationship within the Context of Southeastern Anatolia Project]. Analiz Turkiye, 3(4), 12-23.

Bird, G., \& Rowlands, D. (2017). The Effect of IMF Programmes on Economic Growth in Low Income Countries: An Empirical Analysis. The Journal of Development Studies, 53(12), 2179-2196. doi:10.1080/00220388.2017.1279734

Boratav, K. (1990). Inter-Class and Intra-Class Relations of Distribution under 'Structural Adjustment': Turkey during the 1980s. In T. Aricanli \& D. Rodrik (Eds.), The Political Economy of Turkey: Debt, Adjustment and Sustainability (1st ed.). New York: The US: Palgrave Macmillan.

Boratav, K. (1999). 1980'li yıllarda Türkiye'de Sosyal Sınıflar ve Bölüşüm [Social Classes and Distribution in Turkey in the 1980s] (3rd ed.). Istanbul: Turkey: Gerçek.

Boratav, K. (2005). Türkiye iktisat Tarihi 1908-2002 [Turkey's Economic History 1908-2002] (9th ed.). Istanbul, Turkey: Imge.

Boratav, K. (2009). Tarımsal Fiyatlar, İstihdam ve Köylülüğün Kaderi. Mülkiye, 33(262), 9-24.

Borlu, Y. (2015). A Story of Post-Fordist Exploitation: Financialization and Small-Scale Maize Farmers in Turkey. Rural Sociology, 80(2), 173-197. doi:10.1111/ruso.12061

Bosso, C. (2017). Framing the Farm Bill: Interests, Ideology, and Agricultural Act of 2014 (1st ed.). Kansas, the US: University Press of Kansas. 
Boudon, R. (2009). Rational Choice Theory. In B. S. Turner (Ed.), The New Blackwell Companion to Social Theory (1st ed., pp. 179-196). West Sussex, the United Kingdom: Wiley-Blackwell.

Bozarslan, H. (1996). Political Crisis and the Kurdish Issue in Turkey. In R. Olson (Ed.), The Kurdish Nationalist Movement in the 1990s (1st ed.). Kentucky: the US: the University Press of Kentucky.

Bozkurt, U. (2013). Neoliberalism with a Human Face: Making Sense of the Justice and Development Party's Neoliberal Populism in Turkey. Science \& Society, 77(3), 372-396. doi:10.1521/siso.2013.77.3.372

Brown, C. S. (2007). Turkey in the Gulf Wars of 1991 and 2003. Turkish Studies, 8(1), 85-119. doi:10.1080/14683840601162054

Bruinessen, M. v. (1992). Agha, Shaikh and State: The Social and Political Structures (1st ed.). London: Zed Books.

Bryman, A. (2012). Social Research Methods (4th ed.). New York, USA: Oxford University Press.

Bryman, A. (2016). Social Research Methods (5th ed.). Oxford, the UK: Oxford University.

Buchanan, J. M., \& Tullock, G. (1962). The Calculus of Consent : Logical Foundations of Constitutional Democracy. Ann Arbor: The US: The University of Michigan.

Buğra, A. (2008). Kapitalizm, Yoksulluk ve Türkiye'de Sosyal Politika [Capitalism, Poverty and Social Policy in Turkey] (1st ed.). Istanbul, Turkey: Iletisim.

Busch, L. (2010). Can Fairy Tales Come True? The Surprising Story of Neoliberalism and World Agriculture. Sociologia Ruralis, 50(4), 331-351. doi:doi:10.1111/j.1467-9523.2010.00511.x

Cakmak, E. H., \& Yeldan, A. E. (1994). The Role of Agriculture in the Structural Adjustment Experience of Turkey: A General Equilibrium Analysis. In M. Allaya \& B. Thabet (Eds.), Food and Agricultural Policies in the Middle East and North Africa: Egypt, Lebanon, Morocco, Sudan, Tunisia, Turkey (Vol. 7, pp. 221-267). Montpellier, France: CIHEAM.

Çakmaklı, C., Demiralp, S., Yeşiltaş, S., \& Yıldırım, M. A. (2018). Tütün Ürünlerine Uygulanan Dolaylı Vergierin Enflasyona Etkileri. Retrieved from https://eaf.ku.edu.tr/calismaraporlari

Can, M., Sayılı, M., Yılmazçoban, M., \& Bilici, İ. (2014). Tarım İşletmelerinin Pazarlama Kabiliyetlerini Geliştirmek için Verilen Hibelerden Yararlanma Durumu [The Case of Agricultural Organisations Benefiting from the Grant Supports to Improve their Marketing Capabilities]. Çankırı Karatekin Üniversitesi Sosyal Bilimler Enstitüsü Dergisi, 5(1), 109-132.

Çarkoğlu, A. (2012). Economic evaluations vs. ideology: Diagnosing the sources of electoral change in Turkey, 2002-2011. Electoral Studies, 31(3), 513-521. doi:https://doi.org/10.1016/i.electstud.2012.02.005

Casier, M., Jongerden, J., \& Walker, N. (2015). Fruitless Attempts? The Kurdish Initiative and Containment of the Kurdish Movement in Turkey. New Perspectives on Turkey, 44, 103-127. doi:10.1017/S0896634600005951

Çavdarcı, G. (February 23, 2017). Çukobirlik DFiF Borçları İçin Yeniden Yapılandırma Talebinde Bulundu [The Cukobirlik Requested For Re-Structuring Its DFIF Debt]. Dünya.

Çelik, A. (2008, 24 July). Yeşil Rize'de Sarı Sendikacılık [Yellow Trade Unionism in the Green Rize]. Birgün. Retrieved from https://www.birgun.net/haber-detay/yesil-rize-de-sari-sendikacilik$\underline{4180 . h t m l}$

Çelik, Ö. A. (January 8, 2019). 'Türkiye'yi Ne Erdoğan Ne Bahçeli Yönetiyor; Daha Güçlü ve Daha Derin Bir Akıl Yönetiyor' [Neither Erdogan Nor Bahceli Is Governing Turkey; a Stronger and Deeper Mind Is Doing So]. Gazete Duvar. Retrieved from https://www.gazeteduvar.com.tr/yazarlar/2019/01/08/603381/

Cernea, M. M. (1994). Using Knowledge from Social Science in Development Projects. Project Appraisal, 9(2), 83-94. doi:10.1080/02688867.1994.9726935

CETIM. (2000). WTO and the Agrarian Reform in the Philippines. Retrieved from https://www.cetim.ch/wto-and-the-agrarian-reform-in-the-philippines/

Çevik, M. (2018). GAP Organik Tarım Küme Projesi Sonuç İleme- Değerlendirme ve Etki Araştırması [The GAP ORGANIC AGRICULTURE CLUSTER PROJECT: FINAL MONITORING \& EVALUATION \& 
IMPACT ASSESSMENT]. Retrieved from

https://erc.undp.org/evaluation/evaluations/detail/9599

Chakraborty, S. (2015). Explaining the Rise in Agricultural Prices: Impact of Neoliberal Policies on the Agrarian Economy. Agrarian South: Journal of Political Economy, 4(2), 232-258. doi:10.1177/2277976015591413

Cihangir, H., Bilgiç, B., \& Aba, T. (2015). IPARD Makine ve Ekipman Desteklerinin Mardin Tarımına Etkisi. Tarım Makinaları Bilimi Dergisi, 11(1), 25-31.

Civelek, F. (2011). NUTS of Turkey on First Level. In. Retrieved on 30 September, 2018 from https://commons.wikimedia.org/wiki/File:NUTS Map of Turkey.png. Creative Commons Attribution-Share Alike 3.0 Unported.

Cizre-Sakallioglu, U. (1997). The Anatomy of the Turkish Military's Political Autonomy. Comparative Politics, 29(2), 151-166. doi:10.2307/422077

Cizre-Sakallioglu, U. (2003). Demythologyzing the National Security Concept: The Case of Turkey. Middle East Journal, 57(2), 213-229.

Cizre-Sakallioglu, U., \& Erinç, Y. (2000). Politics, Society and Financial Liberalization: Turkey in the 1990s. Development and Change, 31(2), 481-508. doi:doi:10.1111/1467-7660.00163

Cizre, Ü., \& Çinar, M. (2003). Turkey 2002: Kemalism, Islamism, and Politics in the Light of the February 28 Process. South Atlantic Quarterly, 102/2-3, 309-332.

Cohen, D., \& Crabtree, B. (2006). Qualitative Research Guidelines Project. Retrieved from http://www.qualres.org/HomeStra-3813.html

Connell, R., \& Dados, N. (2014). Where in the world does neoliberalism come from? Theory and Society, 43(2), 117-138. doi:10.1007/s11186-014-9212-9

Cowen, M. P., \& Shenton, R. W. (1996/2005). Doctrines of Development. London, the UK: Routledge.

Cowen, T. (n.d.). Public Goods. Retrieved from https://www.econlib.org/library/Enc/PublicGoods.html

Curtis, A. (2005). Nationalism in the Diaspora: A Study of the Kurdish Movement. Retrieved from http://www.tamilnation.co/selfdetermination/nation/kurdish-diaspora.pdf

Dağlı, H., \& Eker, D. (2016). Türkiye'de Gıda İçecek ve Tütün Sektöründe Faaliyet Gösteren İşletmelerin Ölçekleri Açısından Finansal Oranlarının Karşılaştırmalı Analizi [A Comparative Financial Ratio Analysis in Terms of Business Scale in Turkish Food Beverage and Tobacco Sector]. Aівய̈ Sosyal Bilimler Enstitüsü Dergisi, 16(2), 99-114.

Daldal, A. (2004). The new middle class as a progressive urban coalition: the 1960 coup d'etat in Turkey. Turkish Studies, 5(3), 75-102. doi:10.1080/1468384042000270335

Davutoğlu, A. (2001). Stratejik Derinlik: Türkiye'nin Uluslararası Konumu [The Strategic Depth: Turkey's International Position] (1st ed.). Istanbul: Küre Yayınları.

de Koninck, R., \& Rousseau, J.-F. (2013). Southeast Asian Agricultures: Why such Rapid Growth? [Pourquoi et jusqu'où la fuite en avant des agricultures sud-est asiatiques ?]. L'Espace géographique, 42(2), 143-164.

Değirmenci, E. (2014). Türkiye'de Tarımsal Dönüşüm ve Yeniden Metalaşma [Agricultural Transformation and Re-Commodofication in Turkey]. (MA Master's Thesis), Ankara University, Available from The National Thesis Centre of the Board of Higher Education

Demir Kaya, H. (2016a). Bir Yerel Kalkınma Örneği: Sason Çilek Üreticileri Birliği [A Case of Local Development: the Sason Strawberry Producers Union]. GAP TEYAP, 5, 14-19. Retrieved from https://www.gapteyap.org/dokumanlar/dergilerimiz.

Demir Kaya, H. (2016b). Sason İlçesinde Çilek Yetiştiriciliği Alanında Alçak Tünel Uygulaması [The Implementation of Low Tunnels in Strawberry Cultivation in Sason Town] GAP TEYAP, 4, 12 15. Retrieved from https://www.gapteyap.org/dokumanlar/dergilerimiz.

Demirtaş'tan Gezi Parkı Direniş Yorumu [Demirtas' Comment over the Gezi Resistance]. (2013, 1 June). Cumhuriyet. Retrieved from http://www.cumhuriyet.com.tr/haber/diger/425288/Demirtas tan Gezi Parki direnis yoru $\underline{\text { mu.html }}$ 
Deniz, H. (2010). Diyarbakır ili Sanayi Raporu [The Industrial Report of Diyarbakir Province]. Retrieved from http://investdiyarbakir.com/tr-tr/bilgimerkezi/?sayfa=1\&type=doc

Diamond, L. (2010). The State and Violence: A Discussion of Violence and Social Orders: A Conceptual Framework for Interpreting Recorded Human History. Perspectives on Politics, 8(1), 293-296. doi:10.1017/S1537592709992593

Directorate for EU Affairs. (2017). IPA I \& IPA II Programming. Retrieved from https://www.ab.gov.tr/45627 en.html

Doğan, E. (2005). The Historical and Discoursive Roots of the Justice and Development Party's EU Stance. Turkish Studies, 6(3), 421-437. doi:10.1080/14683840500235498

Doğan, O. (2012). Tracing the Accumulation By Dispossession Moments of Turkish Tobacco Sector within the Neoliberal Transformation. (Master's Thesis), Bilgi University,

Donat, I. (May 24, 2018). Tarımda Kur Etkisi [The Impact of Exchange Rates on Agriculture]. BloombergHT. Retrieved from https://www.bloomberght.com/yorum/irfan-donat/2123596tarimda-kur-etkisi

Düzel, N. (August 6, 2012). Taşçır: Kürtler Kendini Kürt Meclisiyle Yönetmeli [Tascier: Kurds Must Govern Themselves by a Kurdish Assembly]. T24. Retrieved from https://t24.com.tr/haber/imam-tascier-kurtler-kendini-kurdistan-parlamentosuylayonetmeli,210195

Eker, M. (2015). Türkiye Tarımının Değişim ve Dönüşüm Süreci [The Continuum of Change and Transformation in Turkey's Agriculture] (3rd ed.). Istanbul, Turkey: Alfa.

Eldem, T. (2017). Democratic Control and Military Effectiveness of the Turkish Armed Forces. In A. Croissant \& D. Kuehn (Eds.), Reforming Civil-Military Relations in New Democracies (1st ed., pp. 171-192). Cham: Springer.

Engin, A. (1999). Kahhar ve Kerim Devlet [The Destructive and Gracious State]. Birikim, 125126(September-October).

Enriquez, L. (2010). Reactions to the Market: Small Farmers in the Economic Reshaping of Nicaragua, Cuba, Russia, and China. University Park: Pennsylvania State University Press.

Eraktan, G., Abay, C., Miran, B., \& Olhan, E. (2004). Türkiye'de Tarımın Teşvikinde Doğrudan Gelir Desteği Sistemi ve Sonuçları [The Scheme of Direct Income Support in Encouraging Agriculture in Turkey and Its Results] (1st ed.). Istanbul, Turkey: Istanbul Chamber of Commerce

Erdal, G., \& Erdal, H. (2008). Türkiye'de Tarımsal Desteklemeler Kapsamında Prim Sistemi Uygulamalarının Etkileri [The Effects of Premium Payment in Turkey Agricultural Supports System]. Gaziosmanpaşa Universitesi Ziraat Fakültesi Dergisi, 25(1), 41-51.

Erdil, M. (2014, July 24). Yan Yana Tarla Dört Kat Fatura [Farms Side by Side, a Quadrupled Bill]. Hurriyet. Retrieved from http://www.hurriyet.com.tr/yan-yana-tarla-dort-kat-fatura26872930

Ergil, D. (2000). The Kurdish Question in Turkey. Journal of Democracy, 11(3), 122-135.

Erşan, H. (n.d.). Güneydoğu Anadolu Projesi (Gap) Eylem Plani ile Sağlanan Gelişmeler [The Developments Made by the Action Plan of the South-eastern Anatolia Project]. Retrieved from https://docplayer.biz.tr/9665493-Guneydogu-anadolu-projesi-gap-eylem-plani-ilesaglanan-gelismeler.html

Ertuna, Ö. (2005). TL'nin Aşırı Değerlenmesinin Makro ve Mikro Çelişkisi [The Macro and Micro Dilemma of Overvalued Turkish Lira]. Muhasebe ve Finansman Dergisi, 25, 6-17. Retrieved from http://dergipark.gov.tr/mufad/issue/35594/395228

Escobar, A. (1997). Anthropology and development. International Social Science Journal, 49(154), 497-515. doi:10.1111/j.1468-2451.1997.tb00040.x

Esen, B., \& Gumuscu, S. (2018). Building a Competitive Authoritarian Regime: State-Business Relations in the AKP's Turkey. Journal of Balkan and Near Eastern Studies, 20(4), 349-372. doi:10.1080/19448953.2018.1385924 
Eurostat. (2017). Small and large farms in the EU - Statistics from the Farm Structure Survey. Retrieved from http://ec.europa.eu/eurostat/statisticsexplained/index.php/Small and large farms in the EU statistics from the farm structure survey\#Size classes

Fearon, J. D. (2003). Ethnic and Cultural Diversity by Country. Journal of Economic Growth, 8(2), 195222. doi:10.1023/a:1024419522867

Feroz, A. (1993/1995). Modern Türkiye'nin Oluşumu [The Making of Modern Turkey] (Y. Alogan Ed. 1st ed.). Istanbul, Turkey: Sarmal.

Fransen, L. W., \& Kolk, A. (2007). Global Rule-Setting for Business: A Critical Analysis of MultiStakeholder Standards. Organization, 14(5), 667-684. doi:10.1177/1350508407080305

Fuglie, K., Heisey, P., King, J., \& Schimmelpfennig, D. (2012). Rising Concentration in Agricultural Input Industries Influences New Farm Technologies. Amber Waves: The Economics of Food, Farming, Natural Resources, \& Rural America, 10(4), 63-70.

Fulginiti, L. E., \& Perrin, R. K. (1998). Agricultural productivity in developing countries. Agricultural Economics, 19(1-2), 45-51. doi:http://dx.doi.org/10.1016/S0169-5150(98)00045-0

Fuller, G. (31 October 2004) Tarihi Itiraf [A Historical Confession]/Interviewer: D. Sevimay. Vatan Newspaper, Retrieved from http://www.gazetevatan.com/tarihi-itiraf-39231-gundem/.

Genc, M. (2014). Osmanlı Imparatorluğunda Devlet ve Ekonomi [The State and Economy in the Ottoman Empire] (11th ed.). Istanbul, Turkey: Otuken.

Genelkurmay'dan Çok Sert Açıklama [A Very Serious Declaration from the General Staff]. (2007, 27 April). Hurriyet. Retrieved from http://www.hurriyet.com.tr/gundem/genelkurmaydan-coksert-aciklama-6420961

Gilbert, J. (2013). What Kind Of Thing Is 'Neoliberalism'? New Formations, 80(80), 7-22. doi:10.3898/nEWF.80/81.Introductlon.2013

Göksel, O., \& Tekdemir, O. (2018). Questioning the 'Immortal State': the Gezi Protests and the Shortlived Human Security Moment in Turkey. British Journal of Middle Eastern Studies, 45(3), 376-393. doi:10.1080/13530194.2016.1262241

Goldstone, J. A. (1991). Revolution and Rebellion in the Early Modern World (1st ed.). Berkeley, the US: University of California Press.

Google Maps. (2017). Mardin. Retrieved March 29, 2017 from https://www.google.co.uk/maps/@37.3190175,39.6004988,356030m/data=!3m1!1e3. In.

Green, D. J., \& Vokes, R. W. A. (1997). Agriculture and the Transition to the Market in Asia. Journal of Comparative Economics, 25(2), 256-280. doi:https://doi.org/10.1006/jcec.1997.1465

Green, D. P., \& Shapiro, I. (1994). Pathologies of Rational Choice Theory: A Critique of Applications in Political Science. New Haven: The US, London: The UK: Yale University Press.

Grojean, O. (2011). Bringing the Organization back in: Pro-Kurdish Protest in Europe. In M. Casier \& J. Jongerden (Eds.), Nationalisms and Politics in Turkey: Political Islam, Kemalism and the Kurdish Issue (1st ed.). Oxon: Routledge.

Gül, U., Arısoy, H., Sivük, H., \& Ataseven, A. (2009). Alternatif Ürün Projesi Kapsamında Tütün ve Bazı Ürünler Arasında Kârlılık Karşılaştırmaları [Comparison between Tobacco and Some Crop Types in Terms of Profitability within the Scope of the Alternative Crop Project]. Tekirda $\breve{g}$ Ziraat Fakültesi Dergisi, 6(3), 215-226.

Gül Yavuz, G., Miran, B., Gürer, B., Yürekli Yüksel, N., \& Demir, A. (2016). Buğday, Dane Mısır ve Çeltik Üretiminde Fark Ödemesi Desteklerinin Etkisi [(1st ed. Vol. TEPGE Publication Nu : 266). Ankara: The Institute of Agricultural Economy and Policy Making.

Gülçubuk, B., Köksal, Ö., Ataseven, Y., Gül, U., \& Kan, M. (2016). Kırsal Kalkınma Desteklerinin Ulusal Düzeyde Etkileri: Tarım ve Kırsal Kalkınmayı Destekleme Kurumu (TKDK) Projelerinin Incelenmesi. Tarım Ekonomisi Araştırmaları Dergisi, 2(1), 32-41.

Gultekin, A. K. (2013). Kürt Topluluklarda Aşiret Tipi Toplumsal Örgütlenme Yapılarında Değişme Dinamiklerine Güncel Bir Bakış: Beğendik-Bedar Örneği (Siirt-Pervari) [A Current Insight into 
the Dynamic of Changes in The Structures of Asiret-Type Social Organisation in Kurdish Communities: the Case of Begendik-Bedar (Siirt-Pervari)]. Praksis, 29, 87-106.

Gumus, S. G. (2008). Economic Analysis of Oriental Tobacco in Turkey. Bulgarian Journal of Agricultural Science, 14(5), 470-475.

Gunes, C. (2012). Explaining the PKK's Mobilization of the Kurds in Turkey: Hegemony, Myth and Violence. Ethnopolitics, 12(3), 247-267. doi:10.1080/17449057.2012.707422

Gunter, M. (2013). Reopening Turkey's Closed Kurdish Opening? Middle East Policy, 20(2), 88-98. doi:doi:10.1111/mepo.12022

Gurbey, G. (1996). The Development of the Kurdish Nationalism Movement in Turkey since the 1980s. In R. Olson (Ed.), The Kurdish Naionalist Movement in the 1990s: Its Impact on Turkey and the Middle East (1st ed.). Kentucky: the US: The University Press of Kentucky.

Gurcan, M. (2015). Arming civilians as a counterterror strategy: The case of the village guard system in Turkey. Dynamics of Asymmetric Conflict, 8(1), 1-22. doi:10.1080/17467586.2014.948026

Gürel, B. (2011). Agrarian Change and Labour Supply in Turkey, 1950-1980. Journal of Agrarian Change, 11(2), 195-219. doi:doi:10.1111/j.1471-0366.2010.00299.x

Güresinli, C. N. (2015). Avrupa Birliği ve Türkiye Tarımsal Destekleme Politikaları ve Yapısal Politikalarının Tarihi Gelişiminin Değerlendirilmesi [The Evaluation of the Historical Developments of Agricultural Support and Structural Policies in the European Union and Turkey]. Retrieved from https://www.tarimorman.gov.tr/ABDGM/Link/37/Ab-Uzmanlik$\underline{\text { Tezleri }}$

Gürsoy, S., Sessiz, A., Eliçin, A. K., Akın, S., \& Esgici, R. (2013). Diyarbakır Ilinin Agro-Ekolojik Alt Bölgelerine Göre Tarımsal Yapı ve Mekanizasyon Özelliklerinin Irdelenmesi [The Assesment of Agricultural Structure and Mechanisation of Diyarbakir with Regard to Its Agro-Ecological Subregions]. Paper presented at the 28. Ulusal Tarımsal Mekanizasyon Kongresi [The 28th Congress of National Agricultural Mechanisation], Konya, Turkey.

Güven, A. B. (2009). Reforming Sticky Institutions: Persistence and Change in Turkish Agriculture. Studies in Comparative International Development, 44(2), 162-187. doi:10.1007/s12116-0089035-7

Harris, L. M. (2008). Modernizing the nation: Postcolonialism, postdevelopmentalism, and ambivalent spaces of difference in southeastern Turkey. Geoforum, 39(5), 1698-1708. doi:http://dx.doi.org/10.1016/i.geoforum.2008.03.002

Harvey, D. (2007). A Brief History of Neoliberalism (1st ed.). Oxford: the UK: Oxford University Press.

Hayek, F. A. (2005). The Road to Serfdom with The Intellectuals and Socialism (1st ed.). London, The UK: The Institute of Economic Affairs.

Hayran, S. (2013). Türkiye'de Tarım Kesiminin Vergilendirilmesi [Taxation of Agriculture Sector in Turkey]. Iğdır Üni. Fen Bilimleri Enst. Der., 3(1), 69-72.

Hilton, A., Casier, M., \& Jongerden, J. (2009). "Road Maps" and Roadblocks in Turkey's Southeast. Retrieved from Middle East Research and Information Project website: https://www.merip.org/mero/mero103009

Horton, L. R. (2013). From Collectivism to Capitalism: Neoliberalism and Rural Mobilization in Nicaragua. Latin American Politics and Society, 55(1), 119-140. doi:doi:10.1111/j.15482456.2013.00186.x

Hosgör, E. (2011). Islamic Capital/Anatolian Tigers: Past and Present. Middle Eastern Studies, 47(2), 343-360. doi:10.1080/00263206.2011.534336

Huang, J., \& Yang, G. (2017). Understanding recent challenges and new food policy in China. Global Food Security, 12, 119-126. doi:https://doi.org/10.1016/i.gfs.2016.10.002

Huber, E., \& Solt, F. (2004). Successes and Failures of Neoliberalism. Latin American Research Review, 39(3), 150-164.

Human Rights Watch. (2005). "Still Critical" Prospects in 2005 for Internally Displaced Kurds in Turkey. Retrieved from https://www.hrw.org/reports/2005/turkey0305/turkey0305.pdf 
Human Rights Watch/Helsinki. (1993). The Kurds of Turkey: Killings, Disappearances and Torture. Retrieved from https://www.hrw.org/sites/default/files/reports/TURKEY933.PDF

Huntington, S. P. (1984). Will More Countries Become Democratic? Political Science Quarterly, 99(2), 193-218. doi:10.2307/2150402

Huntington, S. P. (2002). The Clash of Civilizations and the Remaking of World Order (1st ed.). London, the UK: The Free Press.

Ihlas News Agency. (July 6, 2017). Tmo Fiyat Açıklamadı, Çiftçiler Tefecilerin Eline Düşmek Istemiyor! [The Turkish Grain Board Have Not Declared the Price, Farmers Do Not Want to Fall Into Usurers' Clutches!]. Haber21. Retrieved from http://www.haber21.com/diyarbakir/tmofiyat-aciklamadi-ciftciler-tefecilerin-eline-dusmek-istemiyor-h6506.html

Inalcik, H. (2013). Osmanli ve Modern Turkiye [The Ottoman and Modern Turkey] (1st ed.). Istanbul, Turkey: Timaş

International Food Policy Research Institute. (2017). 2017 Global Food Policy Report. Washington, DC: International Food Policy Research Institute. https://doi.org.10.2499/9780896292529.

Irmak, S. (2012). Sulama Tesislerinde Elektrik Enerjisi Kullanimi ve Erişimde Yaşanan Sorunlar [The Electricity Use in Irrigation Establishments and the Problems with Accessing It]. Paper presented at the The Energy Forum 2011 in the Provinces of Mardin and Sanliurfa, Mardin Sanliurfa.

Isgin, T. (2006). Harran Ovasi Sulu Tarim Isletmelerinde Arazi ve Gelir Dagilimi [Income and Land Distribution Among Farm Households Operating Under the Irrigated Conditions of the Harran Plain]. Tarim Ekonomisi Dergisi, 12(2), 59-68.

Jacks, D. (2017). Data On Real Commodity Prices, 1850 - Present. Real Commodity Prices, 1850-2017. Retrieved from: http://www.sfu.ca/ djacks/data/boombust/index.html

Jalilian, H., \& Weiss, J. (2000). De-industrialisation in sub-Saharan Africa: myth or crisis? Journal of African Economies, 9(1), 24-43. doi:10.1093/jae/9.1.24

Jongerden, J. (2010a). Dams and Politics in Turkey: Utilizing Water, Developing Conflict. Middle East Policy, 17(1), 137-143. doi:10.1111/j.1475-4967.2010.00432.x

Jongerden, J. (2010b). Village Evacuation and Reconstruction in Kurdistan (1993-2002). Etudes Rurales, (186), 77-100. Retrieved from www.cairn.info/revue-etudes-rurales-2010-2-page77.htm.

Jongerden, J. (2015). Türkiye'de İskan Sorunu ve Kürtler: Modernite, Savas ve Mekan Politikaları Üzerine Bir Çözümleme [The Settlement Issue in Turkey and the Kurds: An Analysis of Spatial Policies, Modernity and War] (M. Topal, Trans. 1st ed.). Istanbul: Turkey: Vate.

Jung, D. (2008). "Secularism": A Key to Turkish Politics? In D. Jung \& C. Raudvere (Eds.), Religion, Politics, And Turkey's Eu Accession (1st ed.). New York, the US: Palgrave Macmillan.

Karabacak, K. (2017). Türkiye'de Tütün Tarımı ve Coğrafi Dağııışı [The Tobacco Production in Turkey and Its Geographical Distribution]. Cografi Bilimler Dergisi, 15(1), 27-48.

Karadag, R. (2010). Neoliberal Restructuring in Turkey: From State to Oligarchic Capitalism. (MPIfG Discussion Paper 10/7). Retrieved from http://hdl.handle.net/10419/43284

Karakaş, D. G. (2014). Market-Oriented Transformation of Tobacco Sector in Turkey. Turk Toraks Dergisi, 15, 71-91.

Karaoğlu, M. (2018, 10 July). Mevcut Devleti Nasıl Tarif Edilmeli? [How to Define the Existing State?] [Blog Post]. Retrieved from http://mehmetkaraoglu2015.blogspot.com/2018/07/mevcutdevlet-nasl-tarif-edilmeli.html

Karaosmanoglu, A. L. (2000). The Evolution of the National Security Culture and the Military in Turkey. Journal of International Affairs, 54(1), 199-216.

Karli, B., \& Çelik, Y. (2003). GAP Alanındaki Tarım Kooperatifleri ve Diğer Çiftçi Örgütlerinin Bölge Kalkınmasındaki Etkinliği [The Effectiveness in Regional Development of Sales Cooperatives and Other Farmer Organisations in the GAP Region]. Retrieved from http://www.tepge.gov.tr/Yayinlar.aspx 
Kasaba, R. (1993). Osmanlı Imparatorluğu ve Dünya Ekonomisi: On Dokuzuncu Yüzyıl [The Ottoman Empire and the World Economy: The Nineteenth Century] (K. Emiroglu, Trans. 1st ed.). Istanbul, Turkey: Belge.

Kavak, S. (2012). Kürt Siyasetinin 2000'li Yılları: “Türkiyelileşme” ve Demokratik Toplum Partisi. In B. Ersanli, G. G. Özdoğan, \& N. Uçarlar (Eds.), Türkiye Siyasetinde Kürtler: Direniş, Hak Arayışı, Katılım [Kurds in Turkey's Politics: Resistance, the Pursuit of Rights, Participation (1st ed., pp. 151-202). Istanbul: Iletisim.

Kaya, G. (2015). Internal Migration and its Effects in one of the Underdeveloped Regions of Turkey (The Sample of Adiyaman). International Journal of Humanities and Social Science, 5(3), 71 80.

Kayaalp, E. (2009). From Seed to Smoke: The Re-Making of the Tobacco Market in Turkey. (Doctoral dissertation), Rice University, Texas, The US. Available from Rice University Digital Scholarship Archive. (10269)

Kayaalp, E. (2013). 'If these machines could talk...': experts, cigarettes and policymaking in Turkey. Social Anthropology, 21(4), 479-491. doi:10.1111/1469-8676.12046

Kayhan Pusane, Ö. (2015). Turkey's Military Victory over the PKK and Its Failure to End the PKK Insurgency. Middle Eastern Studies, 51(5), 727-741. doi:10.1080/00263206.2014.979801

Kazak, H. (2018). Bim Mağazalar Zinciri ve Türkiye Perakende Sektörünün Finansal Performanslarının Karşılaştırılması: Bilanço ve Gelir Tabloları Üzerine Oran Analizi Yöntemiyle Bir Araştırma [Comparison of Financial Performances for BIM Chain Stores and Turkey Retail Sector: A Study with Ratio Analysis on Balance Sheet and Income Statements]. Journal of Life Economics, 5(3), 93-120.

Kees, v. D. J., David, H., \& Peter, L. (2012). Tracking Development in South-East Asia and sub-Saharan Africa: The Primacy of Policy. Development Policy Review, 30(s1), s5-s24. doi:doi:10.1111/j.1467-7679.2012.00563.x

Keklik, S., \& Gultekin-Karakas, D. (2018). Anti-tobacco control industry strategies in Turkey. BMC Public Health, 18(1), 282. doi:10.1186/s12889-018-5071-z

Kelly, T. J. (2001). Neoliberal Reforms and Rural Poverty. Latin American Perspectives, 28(3), 84-103.

Keyder, Ç. (1979). The Political Economy of Turkish Democracy. New Left Review, 115(May-June), 344.

Keyder, Ç. (1987). State and Class In Turkey (1st ed.). London: the UK; New York, The US: Verso.

Keyder, Ç. (2014). 2000'lerde Devlet ve Tarım [The State and Agriculture in the 2000s]. In Ç. Keyder \& Z. Yenal (Eds.), Bildiğimiz Tarımın Sonu: Küresel Iktidar ve Köylülük [The End of Agriculture as We Knew It: The Global Power and Peasantry] (2nd ed.). Istanbul: Turkey: Iletisim.

Keyder, Ç., \& Yenal, Z. (2014). Bildiğimiz Tarımın Sonu: Küresel iktidar ve Köylülük [The End of Agriculture as We Knew It: The Global Power and Peasantry] (2nd ed.). Istanbul: Turkey: lletisim.

KHRP. (2002). Ülke İcinde Göç Ettirilen Insanlar: Türkiye'deki Kürtler [The Internally Displaced People: Turkey's Kurds]. Retrieved from http://www.khrp.org/khrp-news/human-rightsdocuments/doc download/49-kuert-goecue.html

Kibaroglu, A., \& Sumer, V. (2007). Diverging water management paradigms between Turkey and the European union. Water International, 32(sup1), 739-749. doi:10.1080/02508060.2007.9671994

Kilicbay, M. A. (2000). Osmanlı'nın Kuruluşu'nun Efsanevi Yanı [The Myrtical Aspect of the Foundation of the Ottoman]. In Osmanlı Devleti'nin Kuruluşu: Efsaneler ve Gerçekler [The Foundation of the Ottoman Empire: Myths and Facts] (1st ed.). Ankara: Imge.

Killick, T. (2003). Imf Programmes in Developing Countries : Design And Impact (1st ed.). London: the UK; New York: the US: Routledge.

Kınacılar, M. (2018, 3 August). Güneydoğubirlik'in Kapatılması Hata İdi [The Closure of Guneydogubirlik Was A Mistake] Gaziantep27.net. Retrieved from http://www.gaziantep27.net/guneydogubirlikin-kapatilmasi-hata-idi-519023h.htm 
Kindleberger, C. P., \& Herrick, B. (1977). Economic Development (3rd ed.). New York: McGraw-Hill. Kırmızıtaş, H., Leylak, A., \& Pınar, Ö. (2010, 23 June). Bakan Eker: GAP bitince terör bitmeyecek [The Minister Eker: When the GAP Completes, Terrorism Will Not End]. Posta. Retrieved from http://www.posta.com.tr/bakan-eker-gap-bitince-teror-bitmeyecek-34328

Kivilcimli, H. (1965a). Tarih Devrim Sosyalizm [History, Revolution and Socialism] (n. ed.). n.p: Kivilcimli Enstitusu. Retrieved from http://www.kivilcimlienstitusu.org/kitaplar.

Kivilcimli, H. (1965b). Tarih Devrim ve Sosyalizm Işığında: ilkel Sosyalizmden Kapitalizme ilk Geçiş ingiltere [In the Light of the History, Revolution and Socialism: The First Transition From Primitive Socialism to Capitalism - England] (n. ed.). n.p: Kivilcimli Enstitusu. Retrieved from http://www.kivilcimlienstitusu.org/kitaplar.

Kivilcimli, H. (2010a). Osmanlı Tarihinin Maddesi : Osmanlı Tarihinin Ruhu [The Essence of the Ottoman History: The Spirit of the Ottoman History] (2nd ed. Vol. 1). Istanbul: Derlenis.

Kivilcimli, H. (2010b). Osmanlı Tarihinin Maddesi : Osmanlı Tarihinin Ruhu [The Essence of the Ottoman History: The Spirit of the Ottoman History] (2nd ed. Vol. 2). Istanbul: Derlenis.

Kivilcimli, H. (2010c). Osmanlı Tarihinin Maddesi : Osmanlı Tarihinin Ruhu [The Essence of the Ottoman History: The Spirit of the Ottoman History] (2nd ed. Vol. 3). Istanbul: Derlenis.

Kizilkaya, B. (2014). Açılımla Yaşamak: Geçmişten Bugüne Kürt Sorununun Çözümüne Dönük Devlet Politikalarının Kürtler Için Anlamı [Living with The Opening: The Meaning of State Policies for Kurds Aimed at Resolving the Kurdish Question From Past to Present] (Master's Dissertation), Ankara University, Ankara, Turkey. Available from Ankara University Open Access System.

Kiziltan, Y. (2006). I. Meşrutiyetin Ilânı ve Illk Osmanlı Meclis-i Mebusan'ı [The Declaration of the First Constitutional and the First Ottoman Assembly of Deputies]. Gazi Eğitim Fakültesi Dergisi, 26(1), 251-272.

KMPG Turkey. (2018). Perakende: Sektorel Bakis [Retail: The Sectoral Outlook]. Retrieved from www.kpmg.com.tr

Koç, A., \& Giray, F. H. (2015). Avrupa Birliği Kırsal Kalkınma Mali Yardımı (IPARD): Türkiye Uygulaması ve Yeni Dönem (2014-2020) Değişiklikler [European Union Instrument for Pre-Accession Rural Development (IPARD): Implementation in Turkey and New Periodamendments (20142020)]. Akademik Bakış Dergisi, 51, 314-331.

Koç, A. A., Codron, J. M., Tekelioglu, Y., Lemeilleur, S., Tozanli, S., Aksoy, S., . . Mencet, N. (2007). Restructuring of Agrifood Chains in Turkey, Turkey National and Local Mesostudy (Modules 1 and 2 of (1) Report. Retrieved from https://prodinra.inra.fr/record/20213

Koçal, A. V. (2014). Osmanli-Türkiye Modernleşmesinin Sosyo-Ekonomik Temelleri Ve Aktörleri Bağlaminda 'Türk'-Kürt Ikileminin Doğuşu ve Kaynaklari [The Emergence and Factors of The Dilemma between the Turk and the Kurd in the Context of Socio-Economic Bases and Actors of the Ottoman-Turkey Modernisation]. Paper presented at the The International Symposioum of Turks and Kurds in the History, Ankara, Turkey.

Koçal, V. (2015). Bir Siyasal Değişme Etkeni Olarak Göç: Kürt Kimliğinin Siyasal Evriminde Göç Dinamiği Örneği - Nedenler ve Sonuçlar [Migration as a Factor Leading to Political Change: The Case of Migration Dynamics in the Evolution of the Kurdish Identity - Reasons and Results]. Idealkent, 6(15), 214-241.

Koçtürk, D., \& Avcıoğlu, A. O. (2007). Türkiye'de Bölgelere ve Illere Göre Tarımsal Mekanizasyon Düzeyinin Belirlenmesi. Tarım Makinaları Bilimi, 3(1), 17-24.

Kökce, H. K. (2010). Two Transformative Actors Of Turkish Politics: Justice And Development Party And Kurds. (Master Dissertation), Middle East Technical University, Retrieved from http://etd.lib.metu.edu.tr/upload/12611664/index.pdf

Köseoğlu, B. (2014, 19 May). Soma Holding-Akp Ilişkisinin Kilit Adamı: Ramazan Doğru [The Key Person of the Relationship between Soma Holding Company and the JDP]. Diken. Retrieved from http://www.diken.com.tr/soma-holding-akp-iliskisinin-kilit-adami-ramazan-dogru/

Krueger, A. O. (1990). Government Failures in Development. Journal of Economic Perspectives, 4(3), 9-23. 
Kucuk, Y. (2010). Fitne [Sedition] (1st ed.). Istanbul, Turkey: Mizrak.

Kucukaydin, D. (2011, 20 November). KCK Nedir ve KCK Tutuklamaları Ne Anlama Gelir? [What Is the KCK and What Do the KCK Arrests Mean?] [Blog Post]. Retrieved from https://demirdenkapilar.blogspot.com/2011/11/kck-nedir-ve-kck-tutuklamalar-ne-anlama.html

Kucukaydin, D. (2012). 11 Eylül ve Politik İslam Üzerine Yazılar [Writings on 11th September and Political Islam] (3rd ed.). n.p.: Koxuz Yayinlari.

Kucukaydin, D. (2013a). Gezi Direnişi Yazıları [Writings about the Gezi Protest] (1st Edition ed.). Istanbul, Turkey: Koksuz.

Kucukaydin, D. (2013b). Kemalizm ve Askeri Burokratik Oligarsi Uzerine [On Kemalism and the Military Bureaucratic Oligarchy] (2nd ed.). n.p.: Koxuz Yayinlari.

Kucukaydin, D. (2013, 4 August). Seçimlere Nasıl Girileceği Tartışması Üzerine [On the Discussion over How Will Be Contested in Elections] [Blog Post]. Retrieved from https://demirdenkapilar.blogspot.com/2013/08/secimlere-nasl-girilecegi-tartsmas.html

Kucukaydin, D. (2015, 9 November). Seçim Sonuçları Analizlerinde Hiç Söz Edilmeyen Belirleyici Güç [The Deciding Power that Is Not Ever Mentioned in the Analysis of the Election Result] [Blog Post]. Retrieved from https://demirden-kapilar.blogspot.com/2015/11/secim-sonuclaranalizlerinde-hic-soz.html

Kucukaydin, D. (2016). Deniz Gezmiş ve Kürt Sorunu Üzerine Yazılar [Deniz Gezmis and Writings on the Kurdish Question] (3rd ed.). n.p.: Koxuz Yayinlari.

Küçükşahin, Ş. (2006, 8 October). Dağda Silah Tutacağına Düz Ovada Siyaset Yapsın [Let Them Do Politics Instead of Holding Arms in the Mountain]. Hurriyet. Retrieved from http://www.hurriyet.com.tr/gundem/dagda-silah-tutacagina-duz-ovada-siyaset-yapsin$\underline{5219661}$

Kumar, K. (2017). Visions of Empire: How Five Imperial Regimes Shaped the World. Princeton, NJ: Princeton University Press.

Kurban, D., \& Yegen, M. (2012). Adaletin Kıyısında: 'Zorunlu' Gö̧ Sonrasında Devlet ve Kürtler [On the Edge of Justice: The State and Kurds after the "Forced" Migration] (2nd ed.). Istanbul, Turkey: Türkiye Ekonomik ve Sosyal Etüdler Vakfi.

Kurubas, E. (2008). Etnik Grup - Devlet Sorunsallaşması ve Aktör Tutumlarındaki Açmazlar: Türkiye'deki Kürt Sorunu Örneği [The Problematique of Ethnic Group and the State and Dilemmas in Attitudes of Actors: The Case of Kurdish Question in Turkey]. Liberal Dusunce, 50, 19-53.

Laçiner, Ö. (2001). Ekonomik Kriz: "Sistem Türkiye'ye El Koydu [The Economic Crisis: "The System Took Turkey in Hand". Birikim, 144(April).

Lan, N. (2008). A Network Theory of Social Capital. In D. Castiglione, J. W. Van Deth, \& G. Wolleb (Eds.), The Handbook of Social Capital (1st ed.). Oxford, the UK: Oxford University Press.

Law on Regulating Tobacco, Tobacco Products and Alcohol Market, 4733, The Official Gazette (The General Directorate of Legislative Development and Publication 2002 March 1).

Lemeilleur, S., \& Codron, J.-M. (2011). Marketing cooperative vs. commission agent: The Turkish dilemma on the modern fresh fruit and vegetable market. Food Policy, 36(2), 272-279. doi:https://doi.org/10.1016/i.foodpol.2010.11.024

Leys, C. (1996). Rational choice or Hobson's Choice? The "new political economy" as development theory. Studies in Political Economy, 49(1), 37-69. doi:10.1080/19187033.1996.11675342

Luan, Y., Cui, X., \& Ferrat, M. (2013). Historical trends of food self-sufficiency in Africa. Food Security, 5(3), 393-405. doi:10.1007/s12571-013-0260-1

Mann, M. (2005). The Sources of Social Power: A History of Power from the Beginning to A.D. 1760 (1st ed. Vol. I). New York, the US: Cambridge University Press.

Mardin, S. (1969). Power, Civil Society and Culture in the Ottoman Empire. Comparative Studies in Society and History, 11(3), 258-281.

Mardin, S. (1973). Center-Periphery Relations: A Key to Turkish Politics? Daedalus, 102(1), 169-190. 
Mazibaş, M., \& Tuna, Y. (2017). Understanding the Recent Growth in Consumer Loans and Credit Cards in Emerging Markets: Evidence from Turkey. Emerging Markets Finance and Trade, 53(10), 2333-2346. doi:10.1080/1540496X.2016.1196895

McDowall, D. (1996). The Kurds. Retrieved from The United Kingdom:

McDowall, D. (1997). A Modern History of The Kurds. London: I.B.Tauris Co Ltd. New York: St Martin's Press.

McDowall, D. (2004). Modern Kürt Tarihi [A Modern History of Kurd] (N. Domaniç, Trans. 1st ed.). Ankara, Turkey: Doruk Yayimlari.

McMichael, P. (2012). The Land Grab and Corporate Food Regime Restructuring. The Journal of Peasant Studies, 39(3-4), 681-701.

Medyascope.tv. (2018, 23 March). AKP'nin Kürt Tabanı Konuk: Prof. Mesut Yeğen [The Kurdish Base of the JDP The Guest: Prof. Mesut Yegen]. In.

Miedema, T. (2010). Violent Conflict and Social Capital in Ethnically-polarized Developing Countries. (Doctoral dissertation), University of Toronto, Retrieved from TSpace Repository http://hdl.handle.net/1807/26301

Monis, T., Çıkman, A., İpekçioğlu, Ş., Çetiner, i. H., Nacar, A. S., Saner, G., . . Kenanoğlu Bektaş, Z. (2012). GAP Bölgesi'nde Organik Tarımın Benimsenmesini Etkileyen Sosyo-Ekonomik Faktörler [ Socio-Economic Factors Affecting the Adoption of Organic Agriculture in the GAP Region] (1st ed.). Şanlıurfa, Turkey: The GAP Agricultural Research Institute.

Moore, M. (1990). The Rational Choice Paradigm and the Allocation of Agricultural Development Resources. Development and Change, 21, 225-246.

Mudge, S. L. (2008). What is neo-liberalism? Socio-Economic Review, 6(4), 703-731. doi:10.1093/ser/mwn016

Müftüler-Baç, M. (2014). Changing Turkish foreign policy towards Iraq: new tools of engagement. Cambridge Review of International Affairs, 27(3), 538-552. doi:10.1080/09557571.2013.840560

Musgrave, R. A., \& Musgrave, P. B. (1989). Public Finance In Theory And Practice (5th ed.). Singapore: McGraw-Hill.

Musser, K. (2005). The Tigris - Euphrates Watershed. In: Retrieved 26 September, 2018 from https://commons.wikimedia.org/wiki/File:Tigr-euph.png . Creative Commons AttributionShare Alike 2.5 Generic.

Mutlu, S. (2011). The Economic Cost of Civil Conflict inTurkey. Middle Eastern Studies, 47(1), 63-80. doi:10.1080/00263200903378675

Narli, N. (1997). The Rise of the Islamist Movement in Turkey Middle East Review of International Affairs, 3(3), 38-48.

North, D. C. (1990). Institutions, Institutional Change and Economic Performance (1st ed.). Cambridge: the UK: Cambridge University Press.

North, D. C. (2005). Understanding the Process of Economic Change (1st ed.). Princeton: Princeton University Press.

North, D. C., Wallis, J. J., \& Weingast, B. R. (2009). Violence and Social Orders: A Conceptual Framework for Interpreting Recorded Human History (1st ed.). New York, the US: Cambridge University Press.

Nyeck, S. (2010). When Things Fell Apart: State failure in late-century Africa, by Robert Bates. African Affairs, 109(437), 672-674. doi:10.1093/afraf/adq053

O'Connor, F. (2017). The Kurdish Movement in Turkey: Between Political Differentiation and Violent Confrontation. Retrieved from Frankfurt am Main: Hessische Stiftung Friedens- und Konfliktforschung: Retrieved from 17 June, 2018 http://nbn-resolving.de/urn:nbn:de:0168ssoar-56326-3

O'Connor, J. (1984). Accumulation Crisis (1st ed.). New York, the US: Basil Blackwell. 
Öcalan'dan Gezi Parkı Mesajı [A Message for Gezi from Ocalan]. (2013, 7 June). Cumhuriyet. Retrieved from http://www.cumhuriyet.com.tr/haber/diger/426356/Ocalan dan Gezi Parki mesaji.html

Ocalan, A. (2001). Sümer Rahip Devletinden Demokratik Uygarliğa: AiHM Savunmaları Cilt II [From the Sumerian Monk State to Democratic Civilisation: The Defence for ECHR Volume II] (1st ed.). Koln: Mezopotamya.

OECD. (2006). Decoupling: A Conceptual Overview. doi:https://doi.org/10.1787/oecd papers-v5art37-en

OECD, \& FAO. (2017). Southeast Asia: Prospects and Challenges. In OECD-FAO Agricultural Outlook 2017-2026 (1st ed.). Paris: France: OECD Publishing.

Olhan, E. (2012). Türkiye'de Reformlar Kapsamında Yoksullaşan Tarım Sektörü [The Impoverishing Agricultural Sector within the Scope of Reforms in Turkey]. Paper presented at the The 10th Congress of Turkey's Agricultural Economy, Konya, Turkey. Retrieved from http://www.tarimarsiv.com/category/yayim-yeri/10-turkiye-tarim-ekonomisi-kongresikonya/.

Olson, M. (2002). The Logic of Collective Action: Public Goods and the Theory of Groups (12th ed.). Massachusetts, the US: Harvard University Press.

Olson, R., \& Bozdaglioglu, Y. (1996). The New Democracy Movement in Turkey: A Response to Liberal Capitalism and Kurdish Ethnonationalism. In R. Olson (Ed.), The Kurdish Nationalist Movement in the 1990s: Its Impact on Turkey and the Middle East (1st ed.). Kentucky: the US: the University Press of Kentucky.

Önal, N. E. (2012). Osmanli Imparatorlugu'ndan Cumhuriyet'e Geciste Büyük Toprak Sahiplerinin Sinifsal Rolü ve Dönüsümü. METU Studies in Development, 39(1), 137-168.

Önal, N. E. (2013). The Effects of Privatization on Agricultural Subsidies and Small-Scale Farming: The Case of Turkey. Paper presented at the Political Economy, Activism and Alternative Economic Strategies, The Hague, Netherlands. Conference Paper retrieved from http://iippe.org/wp/?page id=957

Önder, N. (1998). Integrating with the Global Market: The State and the Crisis of Political Representation. International Journal of Political Economy, 28(2), 44-84. doi:10.1080/08911916.1998.11643965

Öniş, Z. (2004). Turgut Özal and his Economic Legacy: Turkish Neo-Liberalism in Critical Perspective. Middle Eastern Studies, 40(4), 113-134. doi:10.1080/00263200410001700338

Öniş, Z. (2009). Conservative Globalism at the Crossroads: The Justice and Development Party and the Thorny Path to Democratic Consolidation in Turkey. Mediterranean Politics, 14(1), 21-40. doi:10.1080/13629390902747376

Öniş, Z. (2012). The Triumph of Conservative Globalism: The Political Economy of the AKP Era. Turkish Studies, 13(2), 135-152. doi:10.1080/14683849.2012.685252

Öniş, Z. (n.d.). Globalization and Party Transformation: Turkey's Justice and Development Party in Perspective. Retrieved from http://file.setav.org/Files/Pdf/globalization-and-partytransformation-ziya-onis-2005-2006.pdf

Onyx, J., Edwards, M., \& Bullen, P. (2007). The Intersection of Social Capital and Power: An Application to Rural Communities. Rural Society, 17(3), 215-230. doi:10.5172/rsj.351.17.3.215

Oral, N. (2006). Türkiye Tarımında Kapitalizm ve Sınıflar [Capitalism and Classes in Turkey's Agriculture]. In. Retrieved from http://www.zmo.org.tr/yayinlar/kitap goster.php?kodu=71

Oral, N. (2015a). Tarım Satış Kooperatif ve Birliklerinin İşlevsizleştirilmesi [The Disfunctionalisation of Agricultural Sale Cooperatives and Unions]. In N. Oral (Ed.), Türkiye'de Tarımın EkonomiPolitiği (1923-2013) [The Political Economy of Agriculture in Turkey (1923-2013)] (2nd ed., pp. 325-336). Ankara, Turkey: Notabene.

Oral, N. (2015b). Tarımda Özelleştirme Uygulamaları [The Implementations of Privatisation in Agriculture]. In N. Oral (Ed.), Türkiye'de Tarımın Ekonomi-Politiği (1923-2013) [The Political 
Economy of Agriculture in Turkey (1923-2013)] (2nd ed., pp. 299-208). Ankara, Turkey: Notabene.

Orhan, M. (2012). Kurdish Rebellions and Conflict Groups in Turkey during the 1920s and 1930s. Journal of Muslim Minority Affairs, 32(3), 339-358. doi:10.1080/13602004.2012.727294

Oskam, A., Burrell, A., Temel, T., van Berkum, S., Longworth, N., \& Vílchez, I. M. (2004). Turkey in the European Union: Consequences for Agriculture, Food, Rural Areas and Structural Policy. Retrieved from http://library.wur.nl/WebQuery/wurpubs/fulltext/282128

Ostrom, E. (2001). Social Capital: A Fad Or a Fundamental Concept? In P. Dasgupta \& I. Serageldin (Eds.), Social Capital: A Multifaceted Perspective (1st ed.). Washington: The World Bank.

Ostrom, E. (2005). Understanding Institutional Diversity (1st ed.). Princeton, the US: Princeton University Press.

Ostrom, E. (2010a). Beyond Markets and States: Polycentric Governance of Complex Economic Systems. American Economic Review, 100(3), 641-672. doi:doi: 10.1257/aer.100.3.641

Ostrom, E. (2010b). Polycentric Systems for Coping with Collective Action and Global Environmental Change. Global Environmental Change, 20(4), 550-557. doi:https://doi.org/10.1016/i.gloenvcha.2010.07.004

Ostrom, E. (2011). Governing the Commons: The Evolution of Institutions for Collective Action (29th ed.). New York: the US: Cambridge University Press.

Ostrom, E., \& Ahn, T. (2009). The Meaning of Social Capital and Its Link to Collective Action. In G. T. Svendsen \& G. L. H. Svendsen (Eds.), Handbook of Social Capital: The Troika of Sociology, Political Science and Economics (1st ed.). Cheltenham, the UK; Massachusetts, the US: Edward Elgar.

Ostrom, V., Tiebout, C. M., \& Warren, R. (1961). The Organization of Government in Metropolitan Areas: A Theoretical Inquiry. The American Political Science Review, 55(4), 831-842. doi:10.2307/1952530

Owen, R., \& Pamuk, Ş. (2002). 20. Yüzyılda Ortadoğu Ekonomileri Tarihi [A History of Middle East Economies in the Twentieth Century] (A. Edirne, Trans. 1st ed.). Istanbul, Turkey: Sabancl Üniversitesi.

Oya, C. (2007). Agricultural Maladjustment in Africa: What Have We Learned after Two Decades of Liberalisation? Journal of Contemporary African Studies, 25(2), 275-297. doi:10.1080/02589000701396355

Oya, C. (2010). Local and Global Food Distribution: Malfunctioning Markets. Retrieved from http://www.thebrokeronline.eu/Special-Reports/Special-Report-The-heart-of-thematter/Malfunctioning-markets

Oyan, O. (2000). Tarımda Ne Yapılmak ísteniyor? [What Is Meant to Be Done in Agriculture?]. Teori Dergisi, 127, 23-31.

Oyan, O. (2015). Tarımda IMF-DB Gözetiminde 2000'li Yıllar [Agriculture in the 2000s under Supervision of the IMF-the WB]. In N. Oral (Ed.), Türkiye'de Tarımın Ekonomi-Politiği (19232013) [The Political Economy of Agriculture in Turkey (1923-2013)] (2nd ed., pp. 110-130). Ankara, Turkey: Notabene.

Ozcan, A. K. (2006). Turkey's Kurds: A Theoretical Analysis of the PKK and Abdullah Ocalan (1st ed.). London: the UK, New York: the US: Routledge.

Ozcatalbas, O., Boz, I., Demiryurek, K., Budak, D. B., Karaturhan, B., \& Akcaoz, H. (2011). Developing Participatory Extension Applications in Turkey. African Journal of Agricultural Research, 6(2), 407-415.

Ozel , I., \& Atiyas, i. (2011). Regulatory Diffusion in Turkey: A Cross-sectoral Assessment. In T. Çetin \& F. Oğuz (Eds.), The Political Economy of Regulation in Turkey (1st ed.). London, the UK: Springer.

Ozer, D. (2007). Syria and Turkey relations: the changing face of Turkish foreign policy/Suriye ve Turkiye iliskileri: Turk dis politikasinin degisen yuzu. Civilacademy Journal of Social Sciences, $5,15+$. 
Özerol, G. (2013). Institutions of Farmer Participation and Environmental Sustainability: A MultiLevel Analysis from Irrigation Management in Harran Plain, Turkey. International Journal of the Commons, 7(1), 73-91.

Ozok, N. (2004). Social Development As a Governmental Strategy in the South-eastern Anatolia Project. (Master's Dissertation), Bogazici University, Retrieved from https://tez.yok.gov.tr/UlusalTezMerkezi/giris.jsp (Thesis Number 145725)

Öztürk, M. (2012). Agriculture, Peasantry and Poverty in Turkey in the Neo-liberal Age (1st ed.). Netherlands: Wageningen Academic

Öztürk, M., Jongerden, J., \& Hilton, A. (2014). Commodification and the Social Commons: Smallholder Autonomy and Rural-Urban Kinship Communalism in Turkey. Agrarian South: Journal of Political Economy, 3(3), 337-367. doi:10.1177/2277976014560950

Öztürk, M., Jongerden, J., \& Hilton, A. (2018). The (Re)production of the New Peasantry in Turkey. Journal of Rural Studies, 61, 244-254. doi:https://doi.org/10.1016/i.jrurstud.2017.10.009

Öztürk, Ö. (2015). The Islamist Big Bourgeoisie in Turkey. In N. Balkan, E. Balkan, \& A. Öncü (Eds.), The Neoliberal Landscape and the Rise of Islamist Capital in Turkey (Vol. 14, pp. 117-141). New York: Berghahn.

Özuğurlu, M. (2011). Küçük Köylülüğü Sermaye Kapanı: Türkiye Tarım Çalışmaları ve Köylülük Üzerine Gözlemler (1st ed.). Ankara, Turkey: Notabene.

Özuğurlu, M. (2013). "Gazap Üzümleri” Tüm Dramatikliğiyle Yaşanıyor ["The Wrath of Grapes" Being Experienced with Its All Drama]. Perspectives, 6(13), 31-34.

Paderon, M. M. A. (2005). Agricultural Trade Liberalisation Policies from Marcos to MacapagalArroyo. In L. J. R. d. I. Cruz \& M. M. A. Paderon (Eds.), Agricultural Liberalization in the Philippines: Policy History and Competing Perspectives (pp. 5-38). Manila: Institute of Philippine Culture.

Palinkas, L. A., Horwitz, S. M., Green, C. A., Wisdom, J. P., Duan, N., \& Hoagwood, K. (2015). Purposeful Sampling for Qualitative Data Collection and Analysis in Mixed Method Implementation Research. Administration and policy in mental health, 42(5), 533-544. doi:10.1007/s10488-013-0528-y

Pamuk, Ş. (1987). 24 Ocak Sonrasında İktisat Politikaları Sınıflar ve Gelir Dağılımı [Economic Policies, Classes and Income Distribution after 24th January]. In K. Boratav, C. Keyder, \& Ş. Pamuk (Eds.), Kriz, Gelir Dağııımı ve Türkiye'nin Alternatif Sorunu [Crisis, Income Distribution and Turkey's Problem of Finding an Alternative] (2nd ed., pp. 158-178). Istanbul, Turkey: Sistem.

Pamuk, Ş. (2007). Osmanlı-Türkiye Iktisadi Tarihi 1500-1914 [The Ottoman-Turkey Economic History 1500-1914] (4th ed.). Istanbul, Turkey: Iletişim.

Pamukoglu, O. (2003). Unutulanlar Dışında Yeni Bir Şey Yok: Hakkari ve Kuzey Irak Dağlarındaki Askerler [Nothing New Except for The Forgotten Issues: Soldiers in the Mountains of Hakkari and the North Iraq] (3rd ed.). Istanbul, Turkey: Harmoni.

Parlak, M. A. (June 8, 2018). Gaziantep Kirazı Üreticiyi Üzdü, Tüketiciyi Sevindirdi [The Cherry Produced in Gaziantep Has Worried Producers But Pleased Consumers]. Beyaz Gazete. Retrieved from http://beyazgazete.com/video/webtv/ekonomi-2/gaziantep-kirazi-ureticiyiuzdu-tuketiciyi-sevindirdi-551529.html

Patton, M. Q. (2002). Qualitative Research \& Evaluation Methods (3rd ed.). California: the US: SAGE Publications.

Perry, M., Chase, M., Jacob, J. R., Jacob, M. C., \& Laue, T. H. V. (2013). Western Civilization: Ideas, Politics, and Society to 1789 (10th ed. Vol. 1). Boston, the US: Wadsworth.

Polanyi, K. (1945). Origins of Our Time: Great Transformation (1st ed.). London, the UK: Victor Gollancz.

Putnam, R. D. (2000). Bowling Alone: The Collapse And Revival Of American Community (1st ed.). New York, the US: Simon \& Schuster.

Quartet, D. (2004). Osmanlı imparatorluğu 1700-1922 [The Ottoman Empire, 1700-1922] (A. Berktay, Trans. 3rd ed.). Istanbul, Turkey: Iletisim. 
Reaya. Nisanyan, S. (Ed.) (n.d.) in Nisanyan Sozluk [the Nisanyan Dictionary]. Retrieved April 04, 2018 from http://www.nisanyansozluk.com/?k=reayA\&lnk=1.

Robinson, R. D. (1952). Tractors in the Village-A Study in Turkey. Journal of Farm Economics, 34(4), 451-462. doi:10.2307/1233228

Robinson, R. D. (1958). Turkey's Agrarian Revolution and the Problem of Urbanization. Public Opinion Quarterly, 22(3), 397-405. doi:10.1086/266807

Robson, C. (2011). Real World Research: A Resource for Users of Social Research Methods in Applied Settings (3rd ed.). West Sussex, United Kingdom: John Wiley \& Sons.

Rodrik, D. (2006). Goodbye Washington Consensus, Hello Washington Confusion? A Review of the World Bank's Economic Growth in the 1990s: Learning from a Decade of Reform. Journal of Economic Literature, 44(4), 973-987.

Rodrik, D. (2011). Ergenekon and Sledgehammer: Building or Undermining the Rule of Law? Turkish Policy Quarterly, 10(1), 99-109.

Rodrik, D. (2017, November). Rescuing Economics from Neoliberalism. Boston Review. Retrieved from Retrieved on 19, December, 2017 from http://bostonreview.net/class-inequality/danirodrik-rescuing-economics-neoliberalism

Romano, D. (2006). The Kurdish Nationalist Movement: Opportunity, Mobilization, and Identity (1st ed.). New York, the US: Cambridge University Press.

Rosenthal, J.-L. (1998). Analytic Narratives. In R. H. Bates (Ed.), The Political Economy of Absolutism Reconsidered (1st ed., pp. 64-108). Princeton, the US: Princeton University Press.

Sander, O. (1979). Türkiye'nin Batı Bağlantısı 1: A.B.D. ve Türkiye [Turkey's Western Connection 1: the US and Turkey]. Ankara Universitesi SBF Dergisi, 34(1), 63-86.

Savas, K. (1998). Başbakanlık Teftiş Kurulu Başkanı Kutlu Savaş'ın Susurluk Raporu [The Susurluk Report Prepared By Kutlu Savas, The Director of Prime Ministry Inspection Board]. Retrieved from http://akgul.bilkent.edu.tr/Dava/susurluk/kutlu/p1.html

Savran, S. (2004). 20. Yüzyılın Politik Mirası [The Political Inheritance of the 20th Century]. In N. Balkan \& S. Savran (Eds.), Sürekli Kriz Politikaları: Türkiye'de Sınıf, Ideoloji ve Devlet [Policies of Constant Crisis: Class, Ideology and the State in Turkey] (1st ed.). Istanbul: Metis.

Savran, S. (2015). Class, State, and Religion in Turkey. In N. Balkan, E. Balkan, \& A. Öncü (Eds.), The Neoliberal Landscape and the Rise of Islamist Capital in Turkey (1st ed.). Oxford, the UK: Berghahn.

Schejtman, A. (2008). Agriculture: Rural Nonfarm Linkages and Poverty. In G. Kochendorfer-Lucius \& B. Pleskovic (Eds.), Agriculture and Development : Berlin Workshop Series 2008. Herndon, VA, USA: World Bank Publications.

Secor, A. J. (2001). Ideologies in crisis: political cleavages and electoral politics in Turkey in the 1990s. Political Geography, 20(5), 539-560. doi:https://doi.org/10.1016/S0962-6298(01)00011-7

Sengul, H., \& Saribal, O. (2015). Makro-Ekonomik Göstergelerle Türkiye Tarımı [Turkey's Agriculture with Macroeconomic Indicators]. In N. Oral (Ed.), Türkiye'de Tarımın Ekonomi-Politiği (19232013) [The Political Economy of Agriculture in Turkey (1923-2013)] (2nd ed., pp. 131-157). Ankara, Turkey: Notabene.

Şenses, F. (1990). An Assessment of the Pattern of Turkish Manufactured Export Growth in the 1980s and Its Prospects In T. Arıcanlı \& D. Rodrik (Eds.), The Political Economy of Turkey: Debt, Adjustment and Sustainability (1st ed.). The United States of America: Palgrave Macmillan.

Sezer'in Konuşmasının Tam Metni [The Full Text of Sezer's Speech]. (2007, 13 April). Hurriyet. Retrieved from http://www.hurriyet.com.tr/gundem/sezerin-konusmasinin-tam-metni6329346

Skocpol, T. (1988). States and Social Revolutions: A Comparative Analysis of France, Russia, and China (1st ed.). New York: Cambridge University Press.

Southeastern Anatolia Project Regional Development Administration. (2008). GAP Eylem Plani 20082012 [the GAP Implementation Plan 2008-2012]. Retrieved from http://www.gap.gov.tr/siteicerik/gap eylem plani (2008 2012).aspx 
Southeastern Anatolia Project Regional Development Administration. (2014). GAP Eylem Planı 20142018 [The GAP Implementation Plan 2014-2018]. Retrieved from http://www.gap.gov.tr/dosya ekleri/pdf/GAP EYLEM PLANI.pdf

Stein, H. (1992). Deindustrialization, adjustment, the World Bank and the IMF in Africa. World Development, 20(1), 83-95. doi:https://doi.org/10.1016/0305-750X(92)90138-L

Stiglitz, J. E. (1996). Some Lessons From The East Asian Miracle. The World Bank Research Observer, 11(2), 151-177. doi:10.1093/wbro/11.2.151

Stiglitz, J. E. (2007). Is There a Post-Washington Consensus? (Initiative for Policy Dialogue Working Paper Series). Retrieved from http://policydialogue.org/publications/working-papers/

Stiglitz, J. E., \& Schoenfelder, L. (2003). Challenging the Washington Consensus. The Brown Journal of World Affairs, 9(2), 33-40.

Strengthening the Integrated Regional Development and Reduction of Socio-Economic Inequalities in the GAP Region. (18 March, 1997). In (Vol. TUR/95/004/A/01/99): Turkey and the UNDP.

Sugar, P. F. (1977/1993). Southeastern Europe under Ottoman Rule, 1354-1804. Standford, CA: Stanford University Press.

Sungur, O., Keskin, H., \& Dulupçu, M. (2014). Adaptation Of Turkey's Regional Policies To The Eu Acquis: An Evaluation Through Progress Reports (1998-2012). Marmara Journal of European Studies, 21(2), 165-193.

Szreter, S., \& Woolcock, M. (2004). Health by association? Social capital, social theory, and the political economy of public health. International Journal of Epidemiology, 33(4), 650-667. doi:10.1093/ije/dyh013

Tarım Havzaları Yönetmeliği [The Regulation of Agricultural Basins], 27695, The Official Gazette (The General Directorate of Legislative Development and Publication 2010 September 7).

Taylor, L. (1990). The Turkish Experience: Summary and Comparative Notes. In T. Aricanli \& D. Rodrik (Eds.), The Political Economy of Turkey: Debt, Adjustment and Sustainability (1st ed.). The United States of America: Palgrave Macmillan.

Teazis, C. (2010). Adalet ve Kalkınma Partisi: Türkiye'de Ekonomi ve Siyasetin Dönüşümü [Justice and Development Party: The Transformation of Economy and Politics in Turkey]. (Doctoral Dissertation), Ankara University, Retrieved from acikarsiv.ankara.edu.tr/browse/30414/265441.pdf

TEPAV. (2013). 7. Bölgesel Kalkınma ve Yönetişim Sempozyumu Kırsal Kalkınma Politikasının Yönetişimi [The 7th Regional Development and Governance Symposium: the Governance of the Rural Development Policy] (1st ed.). Ankara: TEPAV.

TGNA Directorate of the Minutes Services. (November 16, 2018). Türkiye Büyük Millet Meclisi Plan ve Bütçe Komisyonu Tutanak Dergisi [The Journal of the Minutes of Turkish Grand National Assembly the Plan and Bugdet Committee]. Retrieved from https://www.tbmm.gov.tr/develop/owa/komisyon tutanaklari.goruntule?pTutanakld=2226

TGNA Human Rights Inquiry Committee. (2013). Terör ve Şiddet Olayları Kapsamında Yaşam Hakkı ihlallerini Inceleme Raporu [The Investigation Report on Violations of Right to Life in the Context of Terror and Violence Incidents]. Retrieved from https://www.tbmm.gov.tr/komisyon/insanhaklari/rapor donem24.htm

TGNA Inquiry Commission. (1998). Doğu ve Güneydoğu Anadolu'da Boşaltılan Yerleşim Birimleri Nedeniyle Göç Eden Yurttaşlarımızın Sorunlarının Araştırılarak Alınması Gereken Tedbirlerin Tespit Edilmesi Amacıyla Kurulan Meclis Araştırması Komisyonu Raporu (10/25) [The Assembly Investigation Commission's Report for Defining The Required Measures by Investigating the Problems of Our Citizens that Migrated Due to the Evacuated Settlements in the East and South-east Anatolia (10/25)]. Retrieved from https://www.tbmm.gov.tr/sirasayi/donem20/yil01/ss532.pdf

TGNA Inquiry Committee. (2008). Zeytin ve Zeytinyağı ile Diğer Bitkisel Yağların Üretiminde ve Ticaretinde Yaşanan Sorunların Araştırılarak Alınması Gereken Önlemlerin Belirlenmesi Amacıyla Kurulan Meclis Araştırması Komisyonu Raporu [The Report of the Assembly Inquiry 
Committee Established for Determining the Required Measures to Be Taken by Investigating the Problems of the Trade and Production of Olive, Olive Oil and Other Types of Vegetative Oil]. Retrieved from https://www.tbmm.gov.tr/sirasayi/donem23/vil01/ss296.pdf

The Cabinet. (2014/6052). 2014 Yılında Tarımsal Sulamaya ilişsin Elektrik Borcu Bulunan Çiftçilere Bu Borçları Ödeninceye Kadar Destekleme Ödemesi Yapılmamasına ilişsin Karar [The Decree Regarding Not Paying Agricultural Support Payment to the Farmers in 2014 that Got into Electricity Debt Due to Agricultural Irrigation]. The Official Gazzette Retrieved from http://www.resmigazete.gov.tr/eskiler/2014/03/20140309-11.htm.

The Chamber of Agricultural Engineers in Mardin. (2012). Tarımsal Üretim ve Elektrik Sorunu [Agricultural Production and the Electricity Problem] [Press release]. Retrieved from http://mardinzmo.org.tr/haber-tarimsal-uretim-ve-elektrik-sorunu-17.html

The Competition Authority. (2011). Türkiye Hızlı Tüketim Ürünleri Perakendeciliği Sektör Incelemesi Ön Raporu [The Preliminary Report for the Sectoral Examination of Turkey's Fast Consumption Products]. Retrieved from https://www.rekabet.gov.tr/tr/Sayfa/Yayinlar/sektor-raporlari

The Competition Authority. (2012). Türkiye Hızlı Tüketim Ürünleri Perakendeciliği Sektör Incelemesi Nihai Raporu [The Final Report for the Sectoral Examination of Turkey's Fast Consumption Products]. Retrieved from https://www.rekabet.gov.tr/tr/Sayfa/Yayinlar/sektor-raporlari

The Economist. (2005, April 18th). Peace Be unto You: The Turkish Prime Minister Paves the Way for a Deal with the Kurds. The Economist. Retrieved from http://www.economist.com.

The Energy Market Regulatory Authority. (2015). The Electricity Market: Market Development Report 2014. Retrieved from http://www3.epdk.org.tr/documents/elektrik/rapor yayin/Elk GelisimRaporu2014.pdf

The Exporter Unions of the South-eastern Anatolia. (2016). Sectorial Statistics. Dataset. Retrieved from: http://www.gaib.org.tr/Home/Istatistikler

The GAP-RDA. (2002a). Gap Bölgesinde Sulama Durumu, iklim, Bitki ve Türdeş Alanlar [Irrigation, Climate, Plant and Uniform Areas in the GAP Region]. Retrieved from http://vayin.gap.gov.tr/gap-bolgesinde-sulama-durumu-iklim-bitki-ve-turdes-alanlar-yayincc37a42ea7.html

The GAP-RDA. (2002b). Güneydoğu Anadolu Projesi Bölge Kalkınma Planı Cilt 1: Yönetici Özeti [Southeastern Anatolia Project Regional Development Plan Volume 1: The Summary for Administrators]. Retrieved from http://yayin.gap.gov.tr/gap-bolge-kalkinma-plani20022010-yayin-listesi-93.html

The GAP-RDA. (2002c). Güneydoğu Anadolu Projesi Bölgesel Kalkınma Planı Cilt 2 [Southeastern Anatolian Project Regional Development Plan Volume 2]. Retrieved from http://yayin.gap.gov.tr/gap-bolge-kalkinma-plani-20022010-yayin-listesi-93.html

The GAP-RDA. (2003). GAP'ta Son Durum 2002 [The Last State of the GAP 2002]. Retrieved from http://yayin.gap.gov.tr/pdf-view/web/index.php?Dosya=686b2fddb8

The GAP-RDA. (2018). Güneydoğu Anadolu Projesi Son Durum [The Latest State of the South-eastern Anatolian Project]. Retrieved from http://yayin.gap.gov.tr/2017-gap-son-durum-yayin13a66a26b5.html

The GAP-RDA. (n.d.-a). İstatistik Veriler: GAP Bölgesi Teşvik Belgesi, Yatırım, İstihdam [The Statistical Data: GAP Region Incentive Certificates, Investment, Employment]. Retrieved from http://www.gap.gov.tr/istatistiki-veriler-sayfa-63.html

The GAP-RDA. (n.d.-b). İstatistik Veriler: Sanayi Envanteri [The Statistical Data: The Inventory of Industry]. Retrieved from http://www.gap.gov.tr/istatistiki-veriler-sayfa-63.html

the GAP Agricultural Research Institute. (2016). Publications. Retrieved from http://arastirma.tarim.gov.tr/gaptaem/Menu/34/Sonuclanan-Projeler

The GAP Regional Development Administration Directorate. (1993a). GAP Bölgesi Hareket Planı 1993-1997 [The Action Plan for GAP Region 1993-1997]. Retrieved from http://yayin.gap.gov.tr/gap-bolgesi-hareket-plani-19931997-yayin-758e2c1de2.html 
The GAP Regional Development Administration Directorate. (1993b). The GAP Güneydoğu Anadolu Projesi [The GAP South-eastern Anatolian Project] GAP Dergisi, 1, 8-15. Retrieved from http://yayin.gap.gov.tr/gap-dergileri-cilt-11-yayin-e029193f029195a.html.

The GAPRDA. (2012). Gap Sanayi Gelişim Raporu [The GAP Industrial Development Report]. Retrieved from http://yayin.gap.gov.tr/pdf-view/web/index.php?Dosya=4b15ca119d

The General Directorate of Agricultural Reform. (2017). Üretici Birlikleri Listesi [The List of Producers Unions]. Microsoft Excel spreadsheet. Retrieved from: https://www.tarimorman.gov.tr/TRGM/Link/30/Uretici-Birlikleri-Listesi

The General Directorate of Meteorology. (2016). Thornthwaite iklim Sınıflandırmasına Göre Türkiye iklimi [Turkey's Climate as to Thornthwaite Climate Classification]. Retrieved from https://www.mgm.gov.tr/iklim/iklim-siniflandirmalari.aspx

The General Directorate of Meteorology. (2018). Yıllık Toplam Yağış Verileri [The Data of Annual Precipitation]. Retrieved from https://www.mgm.gov.tr/veridegerlendirme/yillik-toplamyagis-verileri.aspx

The Institute for Agricultural Economy and Policy Development. (2015). Tarimsal Veriler [The Agricultural Statistics]. Retrieved from http://www.tarim.gov.tr/Belgeler/SagMenuVeriler/Tarimsal Veriler.pdf

The International Monetary Fund. (1998). Turkey - Memorandum of Economic Policies, June 26, 1998 - Letter of Intent. Retrieved from http://www.imf.org/external/np/loi/062698.htm

The International Monetary Fund. (1999). Letter of Intent of the Government of Turkey on December 9, 1999. Retrieved from http://www.imf.org/external/np/loi/1999/120999.htm

The International Monetary Fund. (2001). Structural Conditionality in Fund-Supported Programs. Retrieved from http://www.imf.org/external/np/pdr/cond/2001/eng/struct/cond.pdf

The IPS at Hacettepe University. (2006). Türkiye Göç ve Yerinden Olmuş Nüfus Araştırması [The Research for Turkey's Migrated and Displaced Population]. Retrieved from Ankara: http://www.hips.hacettepe.edu.tr/TGYONA-AnaRapor.pdf

The Ministry of Agriculture and Forest. (2013). Stratejik Plan 2013-2017 [The Strategic Plan 20132017]. Retrieved from http://www.tarim.gov.tr/Sayfalar/Icerikler.aspx?Icerikld=9b8c607909cb-4c60-8892-37527b56913d

The Ministry of Agriculture and Forest. (2018). Fark Ödemesi Destekleri [The Support of Deficiency Payments]. Retrieved from https://www.tarimorman.gov.tr/Konular/TarimsalDestekler/Fark-Odemesi-Destekleri

The Ministry of Economy. (2017). Makarna [The Pasta]. Retrieved from https://ticaret.gov.tr/data/5b8700a513b8761450e18d81/Makarna.pdf

The Ministry of Economy. (n.d). Industry: Clothing. Retrieved from http://www.ekonomi.gov.tr/portal/ShowProperty?nodeld=\%2FUCM\%2FEK-021144

The MOAF. (2012). Diyarbakir Batman Siirt Development Project IFAD Loan No 718-TR: 2012 Semi Annual Report. Retrieved from http://www.tr.undp.org/content/turkey/tr/home/operations/projects/poverty reduction/D iyarbakir-Batman-Siirt/

The MOAF. (2016). Havza Bazlı Destek Modelinde Çalışmalar Tamamlandı [The Studies on The Basinbased Support Model Has Been Completed] [Press release]. Retrieved from http://www.tarim.gov.tr/Haber/1018/Havza-Bazli-Destek-Modelinde-CalismalarTamamlandi

The Organisation for Economic Co-operation and Development. (2011). Evaluation of Agricultural Policy Reforms in Turkey (1st ed.). Paris, France: OECD Publishing.

The Organisation for Economic Co-operation and Development. (2016a). Agricultural Policy Monitoring and Evaluation 2016 (1st ed.). Paris, France: OECD Publishing.

The Organisation for Economic Co-operation and Development. (2016b). Innovation, Agricultural Productivity and Sustainability in Turkey, (1st ed.). Paris, France: OECD Publishing. 
The Organisation for Economic Co-operation and Development. (2018). Agricultural and Fisheries: 2018 Monitoring and Evaluation Reference Tables [Dataset]. Retrieved from: http://stats.oecd.org/

The State Hydraulic Works. (2012). Tarim: Sulamanin Onemi [Agriculture: The Importance of Irrigation]. Retrieved from http://www.dsi.gov.tr/docs/hizmet-alanlari/tarimsulama.pdf?sfvrsn=2

The State Hydraulic Works. (2015). Güneş Enerjisini Elektrik Enerjisine Dönüştürüyoruz [ We Are Transforming Solar Energy into Electric Energy] [Press release]. Retrieved from http://www.dsi.gov.tr/haberler/2015/03/26/guneseneriisihesenerii

The State Hydraulic Works. (n.d.). GAP Bereketin Diğer Adı [GAP the Other Name of Plentifulness]. Retrieved from http://www2.dsi.gov.tr/dijital/gap-brosur/index.html

The State Planning Organisation. (1989). GAP Master Plan Nihai Raporu Cilt 3 [The Final Report of the GAP Master Plan Volume 3] Retrieved from http://yayin.gap.gov.tr/master-planlar-yayinlistesi-56.html

The State Planning Organisation. (1990). GAP Master Plan Nihai Raporu: Yoneticiler icin Ozet [The Final Report of the GAP Master Plan: the Summary for Administrators] Retrieved from http://yayin.gap.gov.tr/master-planlar-yayin-listesi-56.html

The Tobacco and Alcohol Markets Regulatory Authority. (2016). 2016 Yılı Yaprak Tütün Alım Verileri [The Data on Tobacco Leaf Purchases in 2016] [Data Sheet]. Retrieved from: http://www.tapdk.gov.tr/tr/piyasa-duzenlemeleri/tutun-piyasasi/yaprak-tutun-alimverileri.aspx

The Town Governorship of Samsat. (2013). Samsat Sulama Birliğinin Sorunları Konusunda Toplantı Düzenlendi [A Meeting Held About The Problems About the Irrigation Union of Samsat] [Press release]. Retrieved from http://www.samsat.gov.tr/default B0.aspx?id=164

The UNDP. (2004). Human Development Report Turkey. Retrieved from http://www.tr.undp.org/content/turkey/en/home/library/nationalhdrs/national HDR 2004.html

The UNDP. (2014). New Olive Oil Facility Brings Jobs and Hope to Turkish Host Community [Press release]. Retrieved from http://www.eurasia.undp.org/content/rbec/en/home/presscenter/articles.html

(2015a). Kilis Zeytinleri Dünya Markası Oluyor [Kilis Olives Become A World-wide Brand] [Audio podcast]. Retrieved from https://audioboom.com/posts/2773313-yeni-ufuklar-118-kiliszeytinleri-dunya-markasi-oluyor

The UNDP. (2015b). Kilis'te Açılan Kilizi Entegre Organik Zeytinyağı Tesisi Yerel Ekonomik Kalkınmada Bir Model Olacak [The Kilizi Integrated Organic Olive Oil Facility Opened in Kilis Will Be A Model for Local Economic Development]. Yeni Ufuklar, 110. Retrieved from https://arsiv.yeniufuklar.info/tr-110-subat-2015.

The United Nations. (1992). Agenda 21. Retrieved from https://sustainabledevelopment.un.org/outcomedocuments/agenda21

The World Bank. (1983). World Development Report 1983. Retrieved from https://openknowledge.worldbank.org/handle/10986/5966

The World Bank. (1991). World Development Report 1991: The Challenge of Development (1st ed.). New York, the US: the World Bank.

The World Bank. (2000). World Development Report 2000/2001. Retrieved from https://worldbank.altmetric.com/details/29265626

The World Bank. (2001a). Confirmed Copy - L4631 - Agricultural Reform Implementation Project/Loan - Loan Agreement. Retrieved from http://documents.worldbank.org/curated/en/458181468313247541/Conformed-CopyL4631-Agricultural-Reform-Implementation-Project-Loan-Loan-Agreement

The World Bank. (2001b). Project Appraisal Document on A Proposed Loan in the Amount of Us $\$ 600$ Million to The Republic of Turkey for An Agricultural Reform Implementation Project/Loan 
(21177-TU). Retrieved from

http://documents.worldbank.org/curated/en/928461468760194786/Turkey-Agricultural-

Reform-Implementation-Project

The World Bank. (2009). Implementation Completion and Results Report (Ibrd-46310) On a Loan in the Amount of US\$600 Million to the Republic of Turkey for an Agricultural Reform

Implementation Project (ICR00001155). Retrieved from

http://www.worldbank.org/projects/P070286/agricultural-reform-implementation-projectarip?lang=en

The World Bank. (2017). Databank. World Development Indicators. Retrieved from: http://databank.worldbank.org/data/home.aspx

Togan, S., Bayener, A., \& Nash, J. (2005). Analysis of the Impact of EU Enlargement on the Agricultural Markets and Incomes of Turkey. In B. M. Hoekman \& S. Togan (Eds.), Turkey: Economic Reform and Accession to The European Union (1st ed.). New York, The US: The World Bank.

Tohumculuk Kanunu [The Act of Seed Growing], 5553, The Official Gazette (The General Directorate of Legislative Development and Publication 2006).

Tonus, O. (2007). Openness and Industrialization in Turkey after the Customs Union. MPRA Paper No. 7121. Retrieved from Retrieved from https://mpra.ub.uni-muenchen.de/7121/

Toprak Koruma ve Arazi Kullanımı Kanununda Değişiklik Yapılması Hakkında Kanun [The Law on Amendments on the Law on Soil Preservation and Land Utilisation], Official Gazette, 6537 Stat. (2014).

Toussaint, E. (1999). Your Money or Your Life!: The Tyranny of Global Finance (R. Krishnan \& V. B. Manus, Trans. 1st ed.). London: the UK; Dar es Salam, Tanzania: Pluto Press ; Mkuki na Nyota Press.

Toussaint, E. (2008). The World Bank: A Critical Primer (E. Anne, V. Briault, B. Declercq, S. Dhar, J. Harris, R. Krishnan, M. Lagatta, C. Pagnoulle, V. Renard, G. Sloane-Seale, \& D. Valayden, Trans. 1st ed.). London: the UK; Michigan: the US: Pluto Press.

Tullock, G. (1976). The Vote Motive: An Essay in the Economics of Politics with Applications to the British Economy. London: the UK: The Institute of Economic Affairs.

Türkekul, B., \& Unakıtan, G. (2011). A co-integration analysis of the price and income elasticities of energy demand in Turkish agriculture. Energy Policy, 39(5), 2416-2423. doi:https://doi.org/10.1016/i.enpol.2011.01.064

Turkey Grand National Assembly. (2009, December 25). Tutanak Dergisi. (Term 23, Year 4, Sitting 42). Ankara: TBMM.

Turkey Union of Chamber of Agriculture. (2018). Üretici Market Fiyatlarında Temmuz Ayı [Producer and Market Prices in July]. Retrieved from https://www.tzob.org.tr/basin-odasi/haberler

Turkish Exporters Assembly. (2016). Tarım Raporu 2016 [The Report of Agriculture 2016]. Retrieved from http://www.tim.org.tr/tr/ihracat-arastirma-raporlari.html

Turkish Flour Industrialists' Union. (2012). Un Sanayi Sektör Raporu [The Sectoral Report of The Flour Industry]. Retrieved from http://www.tusaf.org/TR,71/yayinlar.html

Turkish Flour Industrialists' Union. (2015). Buğday Unu Ihracatı : 2011-2015/Ocak-Aralık [The Export of Wheat Flour: 2014-2015/ January-December] [Table]. Retrieved from http://www.tusaf.org/TR,70/istatistikler.html. In.

Turkish Grain Board. (2012). 2012 Yılı Hububat iç Satış Fiyatları [Domestic Grain Prices in 2012]. Retrieved from: http://www.tmo.gov.tr/Upload/Document/istatistikler/tablolar/54 2012hububaticsatis.pdf

Turkish Grain Board. (2014). 2014 TMO İ̧ Satış Fiyatları [TGB Domestic Sale Price in 2014]. Retrieved from: http://www.tmo.gov.tr/Upload/Document/istatistikler/tablolar/2014icsatistr.pdf

Turkish Statistical Institute. (19 April, 2018). Tarımsal Işletme Yapı Araştırması, 2016 [The Study of Agricultural Enterprise Structure, 2016] [Press release]. Retrieved from www.tuik.gov.tr/PdfGetir.do?id=24869 
Turkish Statistical Institute. (1967). Tarımsal Yapı: Üretim, Fiyat, Değer 1967 [Agricultural Structure: Production, Price and Value 2000] [Data book]. Retrieved from: http://kutuphane.tuik.gov.tr/yordambt/yordam.php

Turkish Statistical Institute. (1983). Genel Tarım Sayımı 1980: Hanehalkı Anketi Sonuçları [The 1980 Census of Agriculture: the Result of Household Survey]. Databook. Retrieved from: https://kutuphane.tuik.gov.tr/pdf/0012852.pdf

Turkish Statistical Institute. (1989). Tarımsal Yapı: Üretim, Fiyat, Değer 1989 [Agricultural Structure: Production, Price and Value 1989]. Data book. Retrieved from: http://kutuphane.tuik.gov.tr/yordambt/yordam.php

Turkish Statistical Institute. (1994). Tarımsal Yapı: Üretim, Fiyat, Değer 1994 [Agricultural Structure: Production, Price and Value 1994] [Data book]. Retrieved from: http://kutuphane.tuik.gov.tr/yordambt/yordam.php

Turkish Statistical Institute. (1995). Tarımsal Yapı: Üretim, Fiyat, Değer 1995 [Agricultural Structure: Production, Price and Value 1995] [Data book]. Retrieved from: http://kutuphane.tuik.gov.tr/yordambt/yordam.php

Turkish Statistical Institute. (1998). Tarımsal Yapı: Üretim, Fiyat, Değer 1998 [Agricultural Structure: Production, Price and Value 1998] [Data book]. Retrieved from: http://kutuphane.tuik.gov.tr/yordambt/yordam.php

Turkish Statistical Institute. (1999). Tarımsal Yapı: Üretim, Fiyat, Değer 1999 [Agricultural Structure: Production, Price and Value 1999] [Data book]. Retrieved from: http://kutuphane.tuik.gov.tr/yordambt/yordam.php

Turkish Statistical Institute. (2000). Tarımsal Yapı: Üretim, Fiyat, Değer 2000 [Agricultural Structure: Production, Price and Value 2000] [Data book]. Retrieved from: http://kutuphane.tuik.gov.tr/yordambt/yordam.php

Turkish Statistical Institute. (2001). 2001 Genel Tarım Sayımı Koy Genel Bilgileri [2001 General Agricultural Census Village Information] [Data book]. Retrieved from: https://biruni.tuik.gov.tr/yayin/views/visitorPages/index.zul

Turkish Statistical Institute. (2016a). Bitkisel Ürün Denge Tabloları [Crop Product Balance Sheets]. Merkezi Dağıtım Sistemi [The Central Distribution System] Retrieved October 7, 2016 https://biruni.tuik.gov.tr/medas/?kn=104\&locale=tr

Turkish Statistical Institute. (2016b). Tarım Alet ve Makine Sayıları [The Numbers of Agricultural Equipment and Machinery] Retrieved June 14, 2016 https://biruni.tuik.gov.tr/bitkiselapp/tarimalet.zul

Turkish Statistical Institute. (2017a). Bitkisel Üretim Istatistikleri [Vegetative Production Statistics] [Database]. Retrieved from: https://biruni.tuik.gov.tr/bitkiselapp/bitkisel.zul

Turkish Statistical Institute. (2017b). Konularına Göre Istatistikler [Statistics by Theme]. Retrieved from: http://www.tuik.gov.tr/UstMenu.do?metod=kategorist

Turkish Statistical Institute. (2017c). Merkezi Dağıtım Sistemi: Bitkisel Uretim Istatistikleri [The Central Distribution System: the Statistics of Vegatative Production] [Database]. Retrieved from: https://biruni.tuik.gov.tr/medas/?kn=134\&locale=tr

Turkish Statistical Institute. (2017d). Merkezi Dağıtım Sistemi: Nufus istatistikleri [The Central Distribution System: Population Statistics] [Database]. Retrieved from: https://biruni.tuik.gov.tr/medas/?kn=134\&locale=tr

Turkish Statistical Institute. (2017e). Temel Istatistikler [Main Statistics]. Retrieved from: http://www.tuik.gov.tr/UstMenu.do?metod=temelist

Turkish Statistical Institute. (2017f). Ulusal Hesaplar [National Accounts]. Retrieved from: http://www.turkstat.gov.tr/UstMenu.do?metod=kategorist

Turkish Statistical Institute. (2017g). Yillara Gore II Nufuslari [Population of Provinces by Years]. Retrieved April 02, 2018, from http://www.tuik.gov.tr/UstMenu.do?metod=temelist

Turkish Statistical Institute. (2018a). Bölgesel İstatistikler [Regional Statistics]. Retrieved May 14, 2018 from https://biruni.tuik.gov.tr/bolgeselistatistik/ 
Turkish Statistical Institute. (2018b). Tarımsal Iş̧letme Yapı Istatistikleri [The Statistics of Agricultural Enterprise Structure]. Retrieved from: http://www.tuik.gov.tr/PreTablo.do?alt id=1003

Uluc, V. A. (2007). Güneydoğu Anadolu Bölgesinin Toplumsal ve Siyasal Yapısı: Mardin Örneği'nde Siyasal Katılım [Social And Political Structure of Southeast Anatolia Region: A Case of Political Participation in Mardin]. (PhD Doctoral Dissertation), Istanbul University, Available from Istanbul University DSpace Repository

Unal, F. G. (2012). Land Ownership Inequality and Rural Factor Markets in Turkey (1st ed.). New York, the US: Palgrave Macmillan.

UNDP. (2018). Working Together for Sustainable Development: UNDP in Turkey. Retrieved from http://www.tr.undp.org/content/turkey/en/home/library/corporatereports/workingtogether-for-sustainable-development--undp-in-turkey.html

Unver, I. H. O. (1997). Southeastern Anatolia Project (GAP). International Journal of Water Resources Development, 13(4), 453-484. doi:10.1080/07900629749575

Uznay, F., \& Gümüş, S. G. (2016). Türkiye'de Kayıtdışı Sarmalık Tütün Piyasası ve Yasallaştııılması Üzerine Bir Model Önerisi [A Model Proposal for Illicit Roll Your Own Tobacco Market

and its Legalization in Turkey]. The Journal of Agriculture Faculty of Ege University, 53(2), 223-233. Van den Ban, A. W. (2000). Consultancy Report of the Role of Agricultural Extension in the Development of Irrigated Agriculture in the GAP Region of Turkey. [Unpublished Report].

Varshney, A. (2003). Nationalism, Ethnic Conflict, and Rationality. Perspectives on Politics, 1(1), 8599.

Venugopal, R. (2015). Neoliberalism as concept. Economy and Society, 44(2), 165-187. doi:10.1080/03085147.2015.1013356

Volacu, A., \& Golopenta, I. (2015). First and Second Generation Theories of Collective Action. In D. Kissane \& A. Volacu (Eds.), Modern Dilemmas: Understanding Collective Action in the 21st Century (1st ed.). Stuttgart: Germany: Ibidem-Verlag.

Warner, M. (1997). The Anglo-French Dual Monarchy and The House of Burgundy, 1420-1435: The Survival of an Alliance. French History, 11(2), 103-130. doi:10.1093/fh/11.2.103

Weiss, J. (1993). Industry in Developing Countries: Theory, Policy, and Evidence (3rd ed.). London: Routledge, New York: Routledge.

White, B., Borras Jr, S. M., Hall, R., Scoones, I., \& Wolford, W. (2012). The New Enclosures: Critical Perspectives on Corporate Land Deals. The Journal of Peasant Studies, 39(3-4), 619-647.

White, P. J. (1998). Economic marginalization of Turkey's Kurds: the failed promise of modernization and reform. Journal of Muslim Minority Affairs, 18(1), 139-158. doi:10.1080/13602009808716398

White, P. J. (1999). Citizenship Under the Ottomans and Kemalists: How the Kurds Were Excluded. Citizenship Studies, 3(1), 71-102. doi:10.1080/13621029908420701

Williamson, J. (1993). Democracy and the "Washington consensus". World Development, 21(8), 1329-1336. doi:http://dx.doi.org/10.1016/0305-750X(93)90046-C

Williamson, J. (2004). The strange history of the Washington consensus. Journal of Post Keynesian Economics, 27(2), 195-206.

Wittek, R., Snijders, T. A. B., \& Nee, V. (2014). Introduction: Rational Choice Social Research. In R. Wittek, T. A. B. Snijders, \& V. Nee (Eds.), The Handbook of Rational Choice Social Research (1st ed., pp. 1-32). Redwood City, the US: Stanford University Press. Retrieved from http://ebookcentral.proquest.com/lib/swansea-ebooks/detail.action?doclD=1210895.

Yasli, F. (2014). AKP, Cemaat, Sünni-Ulus: Theses for the New Turkey [JDP, the Cemaat, Sunni Nation: Theses for the New Turkey] (1st ed.). Istanbul, Turkey: Yordam.

Yavuz, M. H. (2001). Five stages of the construction of Kurdish nationalism in Turkey. Nationalism and Ethnic Politics, 7(3), 1-24. doi:10.1080/13537110108428635

Yavuz, M. H. (2003). Islamic Political Identity in Turkey (1st ed.). New York: Oxford University Press.

Yegen, M. (1999). The Kurdish Question in Turkish State Discourse. Journal of Contemporary History, 34(4), 555-568. 
Yegen, M. (2009). "Prospective-Turks" or "Pseudo-Citizens:" Kurds in Turkey. The Middle East Journal, 63(4), 597-615.

Yegen, M. (2011). The Kurdish Question in Turkey: Denial to Recognition. In M. Casier \& J. Jongerden (Eds.), Nationalisms and Politics in Turkey: Political Islam, Kemalism and the Kurdish Issue (1st ed.). Oxon: Routledge.

Yeğen, M. (2006). Turkish nationalism and the Kurdish question. Ethnic and Racial Studies, 30(1), 119-151. doi:10.1080/01419870601006603

Yeldan, A. E. (2006). Küreselleşme Sürecinde Türkiye Ekonomisi [Turkey's Economy in the Process of Globalisation] (12 ed.). Istanbul, Turkey: Iletisim.

Yenal, Z. (2014). Tarım ve Gıda Üretiminin Yeniden Yapılanması ve Uluslararasılaşması [The Internationalisation and Re-Structuring of Agriculture and Food Production]. In K. Ünüvar (Ed.), Bildiğimiz Tarımın Sonu: Küresel iktidar ve Köylülük [The End of Agriculture as We Knew It: The Global Power and Peasantry] (2nd ed.). Istanbul: Turkey: Iletisim.

Yerasimos, S. (1992). Az Gelişmişlik Sürecinde Türkiye [Turkey in the Stage of Less Development] (B. Kuzucu, Trans. 6th ed. Vol. 3). Istanbul, Turkey: Belge.

Yıldırım, A. E. (May 27, 2015). Buğday Hasadı ve Fiyatı [The Wheat Harvest and Its Price]. Retrieved from http://www.tarimdunyasi.net/2015/05/27/bugday-hasadi-ve-fiyati/

Yildirim, E., İnaç, H., \& Özler, H. (2007). A Sociological Representation of the Justice and Development Party: Is It a Political Design or a Political Becoming? Turkish Studies, 8(1), 5 24. doi:10.1080/14683840601138104

Yılmaz, A., \& Arı, A. (2013). Gevşek Parasal Göstergeler ve Enflasyon Hedeflemesi Stratejisi Altında, Enflasyonla Mücadele: 2001-2011 Türkiye Deneyimi [Disinflation under Loose Monetary Indicators and Inflation Targeting Strategy: 2001-2011 Turkish Experience]. Marmara Üniversitesi i.i.B. Dergisi, 34(1), 11-31.

Yilmaz, I., \& Bashirov, G. (2018). The AKP after 15 years: emergence of Erdoganism in Turkey. Third World Quarterly, 1-19. doi:10.1080/01436597.2018.1447371

Yılmaz, S. (2012). Pkk Terör Örgütü ve KCK'da Son Durum [The PKK Terrorist Organisation and the Last State of the KCK]. Turan-Sam Dergisi, 4(15), 6-13.

Yılmaz, Ş. G., \& Gül, M. (2015). İşletmelerde Pamuk Üretim Maliyeti, Karlılık Düzeyinin Değerlendirilmesi: Antalya İli Örneği [The Evaluation of Cotton Production Costs and Profitability Level in Agricultural Farms: The Case of Antalya Province]. Journal of Agricultural Faculty of Mustafa Kemal University, 20(2), 27-41.

Yörük, E. (2014). The Long Summer of Turkey: The Gezi Uprising and Its Historical Roots. South Atlantic Quarterly, 113(2), 419-426. doi:10.1215/00382876-2644203

Yukseker, D. (2008). Diyarbakır'da Yerinden Edilme Sorunu: Geri Dönüş, Kentsel Sorunlar ve Tazminat Yasası'nın Ugulamaları [ The Issue of Displacement in Diyarbakir: Return, Urban-Based Problems, The Implementations of The Compensation Statute". In E. Kalaycioglu \& E. Ege (Eds.), "Zorunlu Göç" ile Yüzleşmek: Türkiye'de Yerinden Edilme Sonrası Vatandaşı̆̆ın Inş̧ası [Being Faced with Forced Migration: The Building Citizenship in Turkey After Displacement] (2nd ed.). Istanbul: TESEV.

Yukseker, D. (2009). Neoliberal Restructuring and Social Exclusion in Turkey. In Z. Onis \& F. Senses (Eds.), Turkish Economy in the Post-Crisis Era: the New Phase of Neo-liberal Restructuring and Integration to the Global Economy (pp. 262-280). London: Routledge.

Yürekli, A., Önder, Z., Elibol, H. M., Erk, N., Çabuk, A., Fisunoğlu, M., . . Chaloupka, F. J. (2010). The Economics of Tobacco and Tobacco Taxation in Turkey. In. Retrieved from http://www.who.int/tobacco/en tfi turkey report feb2011.pdf 